PAULO FERREIRA

\title{
O SISTEMA DE LICENCIAMENTO AMBIENTAL E O DESAFIO ECONÔMICO - PROPOSTA PARA O ESTADO DE SÃO PAULO
}

Tese apresentada à Escola Politécnica da Universidade de São Paulo para obtenção do Título de Doutor em Engenharia.

Área de Concentração:

Engenharia Hidráulica e Sanitária

Orientadora:

Profa. Dra Dione Mari Morita

São Paulo

2010 
Este exemplar foi revisado e alterado em relação à versão original, sob responsabilidade única do autor e com a anuência de seu orientador.

São Paulo, ....... de outubro de 2010.

Assinatura do autor

Assinatura do orientador

FICHA CATALOGRÁFICA

Ferreira, Paulo

O sistema de licenciamento ambiental e o desafio econômico: proposta para o Estado de São Paulo / P. Ferreira. -- ed.rev. -São Paulo, 2010. 228 p.

Tese (Doutorado) - Escola Politécnica da Universidade de São Paulo. Departamento de Engenharia Hidráulica e Sanitária.

1. Meio ambiente 2. Impactos ambientais 3. Licenciamento I. Universidade de São Paulo. Escola Politécnica. Departamento de Engenharia Hidráulica e Sanitária II. t. 


\section{Dedicatória}

À Marli, com amor.

Plante de manhã a sua semente, e mesmo ao entardecer não deixe suas mãos ficarem à toa, pois você não sabe o que acontecerá, se esta ou aquela produzirá, ou se as duas serão igualmente boas. 


\section{AGRADECIMENTOS}

Não seria possível externar a minha gratidão a todos os que de alguma forma me ajudaram a concluir esse trabalho.

Com a nítida sensação de que estou omitindo muitas pessoas e amigos, não posso deixar de externar meu maior agradecimento a essa extraordinária personalidade da Engenharia Sanitária e Ambiental, que é a Prof ${ }^{a}$ Dr $^{a}$ Dione Mari Morita, minha orientadora.

Acompanho a Prof ${ }^{\mathrm{a}}$ Dione Morita desde a graduação e, ao longo de todo esse tempo, só aumentou minha admiração. Seu compromisso ético, sua competência técnica, sua dedicação e capacidade de trabalho, seu grande comprometimento com a causa ambiental são atributos que enaltecem a admiração que seus orientados the devotam.

Agradeço a Elisabeth Fatima da Silva, secretaria de longa data, pela digitação e pesquisa de informações para a elaboração do trabalho.

A inspiração e o estímulo da família, representada pela Patrícia e Walfredo, pela Renata e Celso e pelo Paulo Vinicius, razões pelas quais, na tarde da vida, ainda há razões para prosseguir na luta.

Ao João Antonio (o Leião está peso na foieta, 2002), ao Fernando (quece Dodô, quece: está um lindo dia!, 2006) e a Júlia (você é o simpili e a Dodó é a rainha, 2010), que representam dádivas do céu em nossas vidas e para quem esperamos legar um mundo melhor. 


\section{RESUMO}

As conferências mundiais de meio ambiente de 1972 em Estocolmo e de 1992 no Rio de Janeiro trouxeram um novo despertar para a humanidade nas questões ambientais. Por outro lado, a globalização econômica ampliou de maneira extraordinária os fluxos de produção e comércio, inaugurando uma nova era de crescimento econômico, que trouxe como consequência novas oportunidades de desenvolvimento, mas também pressões sobre os ativos ambientais. A resposta às pressões tem sido um arcabouço legal de regulação, que tem, na visão de alguns, inibido o crescimento econômico e restringido as oportunidades de mobilidade social. As críticas estão concentradas, especialmente nos procedimentos de concessão das licenças ambientais, excessivamente burocráticos, e que acarretam custos econômicos, que reduzem a competitividade dos empreendimentos, principalmente os de infra-estrutura. $O$ presente trabalho procurou analisar, comparativamente, a aplicação desses instrumentos em diversos países, em quatro continentes, com diferentes graus de desenvolvimento, população e nível de renda. Pesquisou as formas de aplicação dos instrumentos das políticas ambientais em diversos estados do Brasil, com suas diferenças de interpretação e de formas de atuação, sob o ponto de vista dos agentes governamentais, das entidades de classe e das organizações da sociedade civil. É apresentada uma análise crítica dos procedimentos e regulamentos em vigor no Estado de São Paulo, bem como é formulada uma proposta de atuação, que objetiva valorizar os procedimentos técnicos e reduzir os burocráticos; integrar as diferentes informações produzidas por diversos órgãos governamentais, importantes para o licenciamento; aumentar a transparência; fortalecer a participação popular e modernizar estruturas de acompanhamento e monitoramento pós-licença.

Palavras-chave: licenciamento ambiental; desenvolvimento sustentável; legislação ambiental; avaliação de impacto ambiental. 


\begin{abstract}
The 1972 Stockholm Environmental World Conference along with its counterpart held in 1992 in Rio de Janeiro generated a wake-up call to humanity regarding environmental issues. On the other hand economic globalization leveraged production and trade flow, launching a new era of economic growth, providing new development opportunities but also concentrating pressures over environmental assets. The response to these pressures has been a framework of legal regulation which has, according to some professionals, inhibited economic growth and restrained opportunities for social advancement. Current critics are focused mostly in excessively bureaucratic environmental permit procedures which carry on economic costs reducing a project's competitive advantage, mainly in infrastructure. The following work attempts to examine comparatively the application of these instruments in several countries, in four Continents, with different levels of development, population and income. Research was made on the various applications of the environmental policies' instruments in several States of Brazil, with its differences in interpretation and decision making process, under the viewpoint of governmental officers, class entities and organizations within society. A critical analysis of the current procedures and regulations in the State of São Paulo is presented along with an engaging proposition that seeks to exalt technical procedures and reduce bureaucratic ones, integrate the diverse but relevant information generated by a number of governmental agencies, increase transparency, strengthen the participation of common people and modernize the follow up apparatus employed in monitoring activity after the permits are submitted.
\end{abstract}

Key words: Environmental permit, sustainable development, environmental legislation, environmental impact assessment. 


\section{SUMÁRIO}

\section{Dedicatória}

Agradecimentos

Resumo

\section{Abstract}

Lista de ilustrações

Lista de tabelas

\section{Lista de abreviaturas e símbolos}

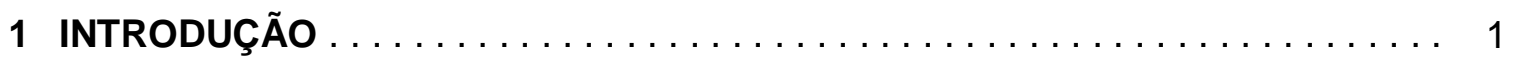

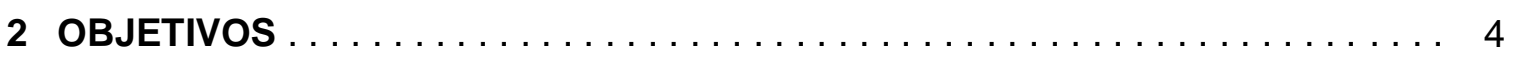

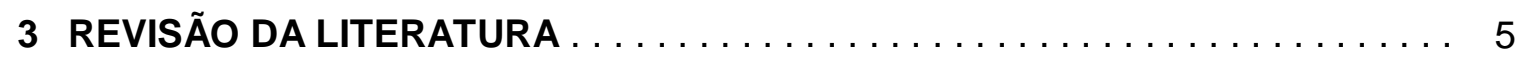

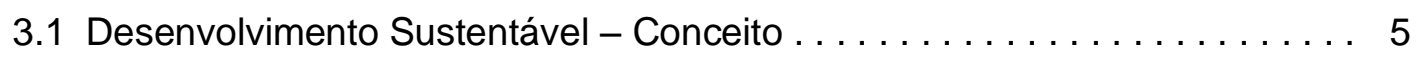

3.2 Licenciamento Ambiental no Brasil . . . . . . . . . . . . . . . . 6

3.3 Avaliação dos Impactos Ambientais (AIA) - Experiência Internacional . . . . 15

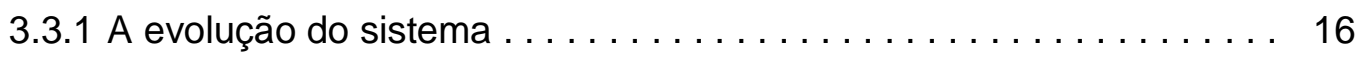

3.3.2 Continente Africano e Oriente Medio . . . . . . . . . . . . . . . . . 18

3.3.2.1 Egito $\ldots \ldots \ldots \ldots \ldots \ldots \ldots \ldots \ldots \ldots \ldots \ldots \ldots \ldots \ldots \ldots \ldots \ldots$

3.3.2.2 Sudão . . . . . . . . . . . . . . . . . . . . . . . . 24

3.3.2.3 Yemen . . . . . . . . . . . . . . . . . . . . . . . 27

3.3.2.4 Gana ... . . . . . . . . . . . . . . . . . . . 31

3.3.2.5 Tanzânia . . . . . . . . . . . . . . . . . . . . 35

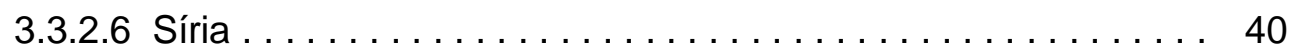

3.3.3 Continente Asiático . . . . . . . . . . . . . . . . . . . 44

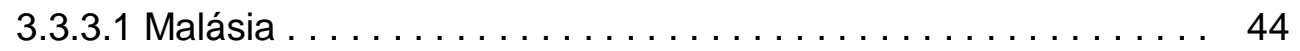

3.3.3.2 Índia . . . . . . . . . . . . . . . . . . . . 49

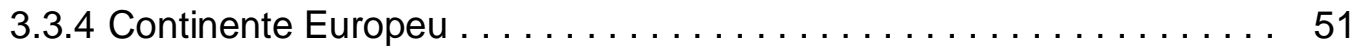

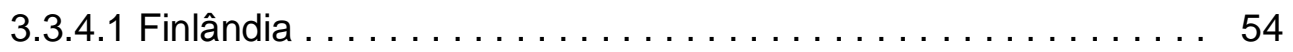

3.3.4.2 Irlanda $\ldots \ldots \ldots \ldots \ldots \ldots \ldots \ldots \ldots \ldots \ldots \ldots \ldots \ldots \ldots$

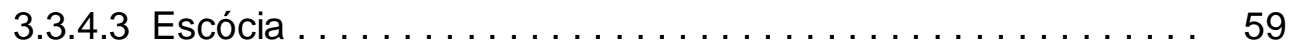

3.3.4.4 Espanha ....................... 60

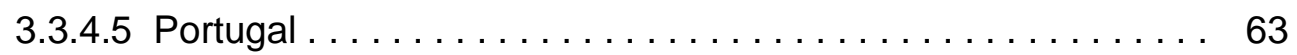

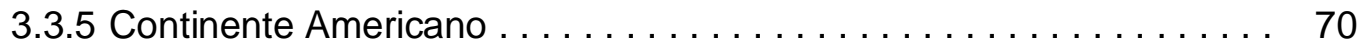

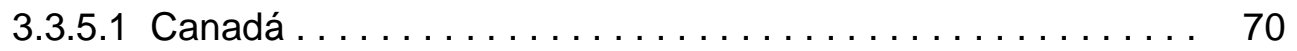

3.3.5.2 Estados Unidos . . . . . . . . . . . . . . . . . 79 
3.3.5.3 Equador $\ldots \ldots \ldots \ldots \ldots \ldots \ldots \ldots \ldots \ldots \ldots \ldots \ldots$

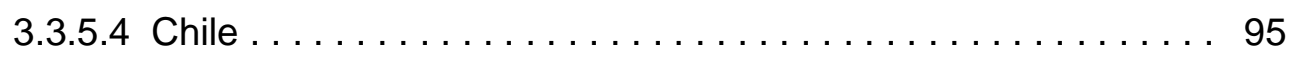

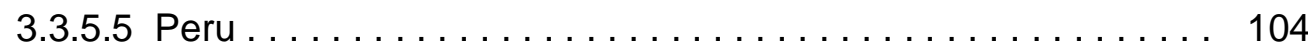

3.3.5.6 Costa Rica .......................... 110

3.3.5.7 Colômbia ................................. 112

3.4 Análise Comparativa .............................. 117

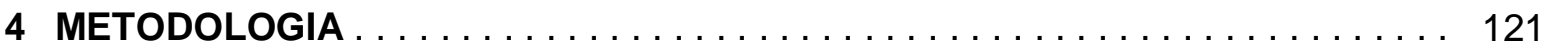

5 ANÁLISE CRÍTICA DOS SISTEMAS DE AVALIAÇÃO AMBIENTAL . . . . . . . 124

5.1 A Perspectiva da Economia . . . . . . . . . . . . . . . . . . . . . . . 125

5.2 A Perspectiva da Produção ............................ 126

5.3 A Perspectiva do Meio Ambiente . . . . . . . . . . . . . . . . . . . . 127

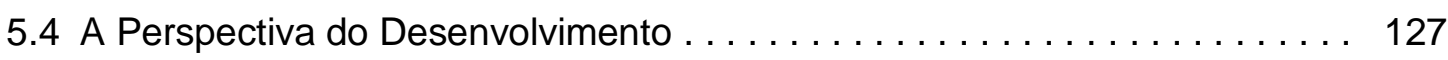

5.5 Avaliação Ambiental Estratégica . . . . . . . . . . . . . . . . . . . . 129

5.6 As Avaliações dos Impactos Ambientais - AlAs . . . . . . . . . . . 130

5.6 .1 Benefícios e custos . . . . . . . . . . . . . . . . . . . 132

5.6 .2 Impacto Ambiental Significativo . . . . . . . . . . . . . . 134

5.6 .3 Seletividade (Screening) . . . . . . . . . . . . . . . . . . 135

5.6.4 Aprofundamento (Scoping) . . . . . . . . . . . . . . . . . . . 137

5.7 Aspectos comparativos entre AAE e AIA . . . . . . . . . . . . . . . 140

5.8 Impactos Ambientais - Licenciamento . . . . . . . . . . . . . . . . . . . 141

5.9 Licenciamento Ambiental no Brasil . . . . . . . . . . . . . . . . . . . 143

5.9 .1 Os agentes financeiros . . . . . . . . . . . . . . . . . . 144

5.9.2 Associações Empresariais . . . . . . . . . . . . . . . . . 153

5.9.2.1 A Confederação Nacional das Indústrias - CNI . . . . . . . . 153

5.9.2.2 Associação Brasileira de Infraestrutura e Indústria de Base . . 158

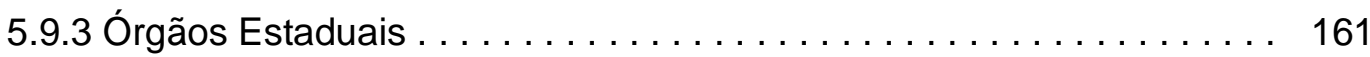

5.9.4 O Sistema de Licenciamento Ambiental no Estado de São Paulo . . . 166

5.9.4.1 Histórico . . . . . . . . . . . . . . . . . . . . . . . . . . . 166

5.9.4.2 A Tripla Licença .............................. 170

5.9.4.3 Entidades Licenciadoras ........................ 172

5.9.4.4 A Judicialização do licenciamento . . . . . . . . . . . . . 178

5.9.4.5 A Atuação das ONGs . . . . . . . . . . . . . . . . . 181

5.9.4.6 Análise do Plano Nacional do Meio Ambiente - PNMA II . . . . 182

5.9.4.7 Reestruturação do Sistema .................... 186

5.9.4.8 A tramitação dos processos durante reestruturação do sistema 196

5.9.4.9 Perspectivas da Reestruturação . . . . . . . . . . . . . . 198 
6 PROPOSTAS PARA O LICENCIAMENTO AMBIENTAL NO ESTAdO DE SÃO

PAULO ......................................... 199

6.1 Propostas Técnicas ................................ 199

6.1 .1 Zoneamento ambiental . . . . . . . . . . . . . . . . . . . . . 199

6.1.2 Relatório técnico ................................ 205

6.1.3 Padrões de emissão e qualidade ...................... 205

6.1.4 Acompanhamento das licenças ...................... 206

6.2 Administrativas . . . . . . . . . . . . . . . . . . . . 206

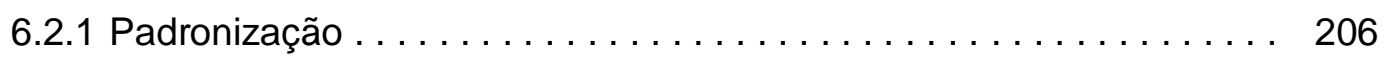

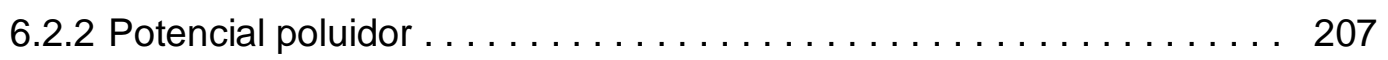

6.2 .3 Pessoal técnico . . . . . . . . . . . . . . . . . . . . . . 207

6.2.4 Descentralização .............................. 208

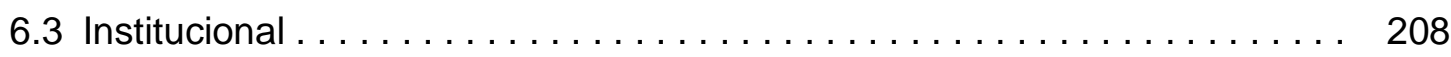

6.3.1 Bacia hidrográfica ........................... 208

6.3 .2 Tripla licença ............................... 209

6.3 .3 Diálogo institucional . . . . . . . . . . . . . . . . . . . 209

6.3.4 Revisão da legislação . . . . . . . . . . . . . . . . . . . . . . . . . 209

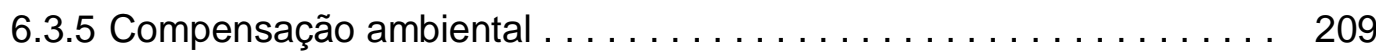

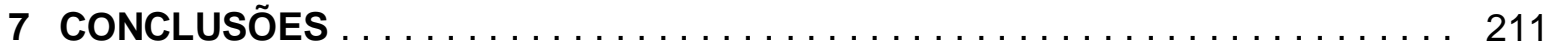

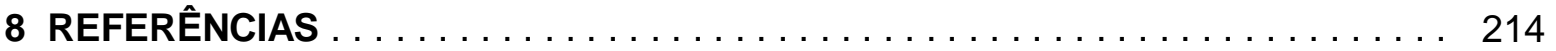




\section{LISTA DE ILUSTRAÇÕES}

Figura 3.1 Fluxograma do processo português $\ldots \ldots \ldots \ldots \ldots \ldots \ldots \ldots$

Figura 5.1 Principais problemas enfrentados pela indústria no processo de

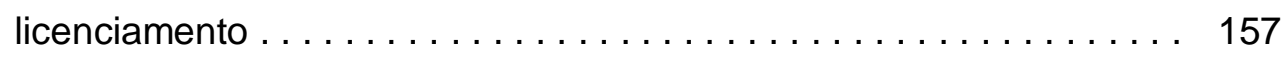

Figura 5.2 Principais problemas na relação entre as empresas e os órgãos

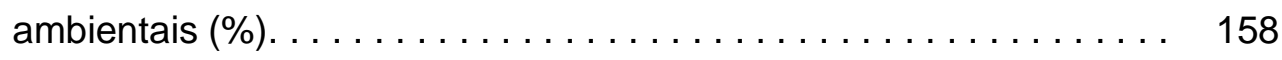

Figura 5.3 Composição dos órgãos licenciadores da Secretaria de Meio Ambiente do Estado de São Paulo . . . . . . . . . . . . . . . . . . 173

Figura 5.4 Fluxograma do licenciamento ambiental no Estado de São Paulo . . . 174

Figura 5.5 Fases de licenciamento para micro e pequenas empresas no Estado

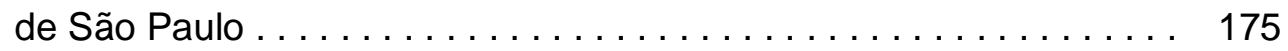

Figura 5.6 Situação do licenciamento ambiental no Estado de São Paulo de maio de 2008 a junho de $2010 \ldots \ldots \ldots \ldots \ldots \ldots \ldots \ldots \ldots$

Figura 5.7 Atendimentos da CETESB ao Ministério Público de 2002 a 2008 . . . 179

Figura 5.8 Tramitação de processos de EIA-RIMA na SMA. Maio 2008 a junho

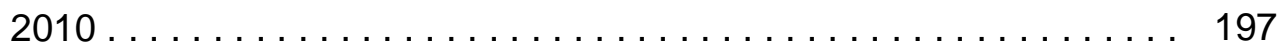

Figura 6.1 Operação do Centro de Sensoriamento Remoto . . . . . . . . . . 200

Figura 6.2 SP Janela eletrônica, exemplo do uso de tecnologia avançada para apoio ao licenciamento ambiental . . . . . . . . . . . . . . . 205 


\section{LISTA DE TABELAS}

Tabela 3.1 Cronologia da base legal do licenciamento ambiental . . . . . . . 11

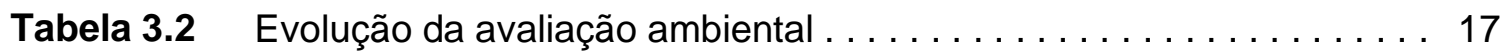

Tabela 3.3 Número de AIAs submetidos à análise na Malásia de 1988 a 1993 . . 46

Tabela 3.4 Tempos Médios para Licenciamento Ambiental no Canadá . . . . . . 76

Tabela 3.5 Cronograma dos prazos para a finalização do licenciamento ambiental de projeto de empreendimento hidrelétrico de grande porte 77

Tabela 3.6 Cronograma dos prazos para a finalização do licenciamento ambiental de projeto de empreendimento hidrelétrico de médio porte 77

Tabela 3.7 Obstáculos que emergem no processo de licenciamento . . . . . . 78

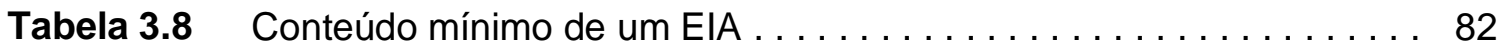

Tabela 3.9 Dimensões de análise dos EIAs . . . . . . . . . . . . . . . 96

Tabela 3.10 Relatórios ambientais entregues ao Ministério do Meio Ambiente

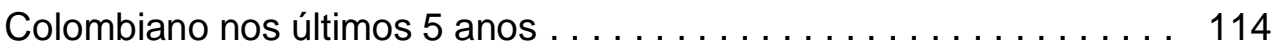

Tabela 3.11 Características das avaliações ambientais em diferentes países de

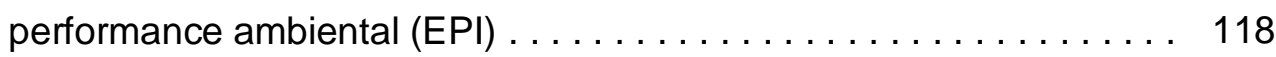

Tabela 5.1 Boas práticas na elaboração da AIA . . . . . . . . . . . . . . . 132

Tabela 5.2 Conteúdos dos estudos de impactos ambientais . . . . . . . . . . . . 138

Tabela 5.3 Diferenças Fundamentais entre AAE e AIA . . . . . . . . . . . . 140

Tabela 5.4 Prazos para análise de EIAs e emissão das licenças do setor elétrico 147

Tabela 5.5 Distribuição do quadro de funcionários do IBAMA de 2002 a $2006 \ldots 148$

Tabela 5.6 Custos relacionados ao licenciamento de empreendimentos em

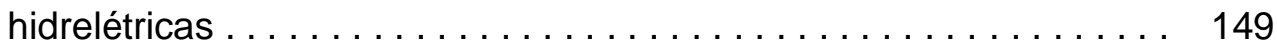

Tabela 5.7 Avaliação da efetividade da AIA na proteção ambiental nos países da América Latina . . . . . . . . . . . . . . . . . . . . . . 152

Tabela 5.8 Posição dos países na competitividade mundial em função das características dos regulamentos ambientais . . . . . . . . . . . . 153

Tabela 5.9 Situação do licenciamento ambiental de empreendimentos elétricos no IBAMA em $2005 \ldots \ldots$. . . . . . . . . . . . . . . . . . . . . . . . . . . 159

Tabela 5.10 Problemas no licenciamento de empreendimentos elétricos e alternativas de soluções propostas pelo ABDIB/IBAMA . . . . . . . 160

Tabela 5.11 Síntese do número de funcionários envolvidos no licenciamento do Estado de São Paulo . . . . . . . . . . . . . . . . . . . . . . . . . . . 176 
Tabela 5.12 Número de licenças emitidas pela CETESB de 2002 a $2008 \ldots \ldots$. . 178

Tabela 5.13 Número de inquéritos e ações civis públicas impetradas pelo

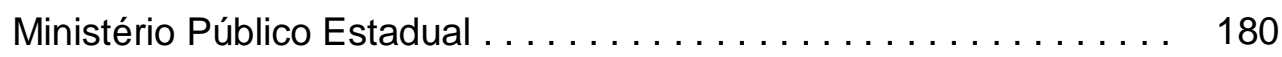

Tabela 5.14 Número de ações impetradas pelo Ministério Público Federal . . . . . 180

Tabela 5.15 Prazos de validade das licenças estipulados pelos Decretos no. $47.397 / 2002$ e no. $53.205 / 2008$ e pelos Decretos $47.400 / 02$ e $n^{\circ}$.

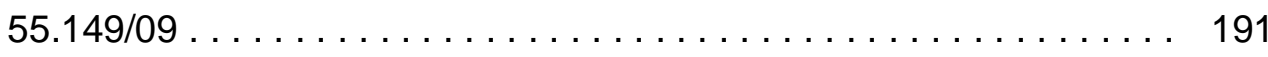

Tabela 5.16 Tempos despendidos para o Licenciamento Ambiental . . . . . . . . . 197 


\section{LISTA DE ABREVIATURAS E SÍMBOLOS}

AA: $\quad$ Autorização Ambiental

AAE: $\quad$ Avaliação Ambiental Estratégica

ABDIB: $\quad$ Associação Brasileira de Infra-estrutura e Indústria de Base

AIA: $\quad$ Avaliação dos Impactos Ambientais

AIE: $\quad$ Agência Internacional de Energia

APA: $\quad$ Agência Portuguesa do Ambiente

ARH: $\quad$ Administração da Região Hidrográfica

BAT: Best Available Techniques

BID: $\quad$ Banco Interamericano de Desenvolvimento

BIRD: $\quad$ Banco Internacional para Reconstrução e Desenvolvimento

BREFs: Best Available Technologies References

CCNMA: Comissão Central para Negócios do Meio Ambiente

CCPCIP: $\quad$ Comissão Consultiva para a Prevenção e Controle Integrado da Poluição

CEAA: $\quad$ Canadian Environmental Assessment Agency

CECPA: $\quad$ Conselho Estadual de Controle da Poluição das Águas

CEQ: $\quad$ Council for Environmental Quality

CETESB: Companhia Estadual de Tecnologia de Saneamento Básico e de Defesa do Meio Ambiente atual Companhia Ambiental do Estado de São Paulo

CNEN: $\quad$ Comissão Nacional de Energia Nuclear

CNI: $\quad$ Confederação Nacional das Indústrias

CNMP: $\quad$ Conselho Nacional do Ministério Público

CONAMA: Conselho Nacional do Meio Ambiente

CONSEMA: Conselho Estadual do Meio Ambiente

COREMA: Comissão Regional do Meio Ambiente

CPCA: $\quad$ Centro de Pesquisa Científica e Ambiental

DAEE: Departamento de Águas e Energia Elétrica

DAIA: Departamento de Avaliação dos Impactos Ambientais

DEPRN: Departamento Estadual de Proteção aos Recursos Naturais 
DERSA: $\quad$ Cia Estadual de Desenvolvimento Rodoviária

DIA: Declaração de Impacto Ambiental

DUSM: $\quad$ Departamento de Uso e Ocupação do Solo em Áreas de Mananciais

EA: $\quad$ Estudo Ambiental

EC: $\quad$ Entidade Coordenadora

EEAA: $\quad$ Egyptian Environmental Affair Agency

EIA: $\quad$ Estudo de Impacto Ambiental

EIARD: $\quad$ Environmental Impact Assessment of Regional Development

EIS: $\quad$ Environmental Impact Statements

EPA: $\quad$ Environmental Protection Agency

EPAct: $\quad$ Environmental Protection Act

EPC: $\quad$ Environmental Protection Council

EPI: $\quad$ Environmental Performance Index

EQA: $\quad$ Environmental Quality Act

ERA: $\quad$ Estudo de Risco Ambiental

ETA: $\quad$ Estações de Tratamento de Água

ETE: $\quad$ Estações de Tratamento de Esgoto

EUA: $\quad$ Estados Unidos da América

FESB: $\quad$ Fomento Estadual de Saneamento Básico

FIESP: $\quad$ Federação das Indústrias do Estado de São Paulo

FR: $\quad$ Federal Register

GIS: $\quad$ Geographic Information System

GPS: $\quad$ Global Positioning System

GRAPROHAB: Grupo de Análise e Aprovação de Projetos Habitacionais do Estado de. São Paulo

IBAMA: Instituto Brasileiro do Meio Ambiente e dos Recursos Naturais Renováveis

IBGE: Instituto Brasileiro de Geografia e Estatística

IEMA: Instituto Estadual de Meio Ambiente

IIA: $\quad$ Insignificantes Impactos Ambientais

INPE: Instituto Nacional de Pesquisas Espaciais 
IPCC: International Pannel of Climate Changes

IPC: Integrated Pollution Control

IPPC: Integrated Pollution Prevention and Control

IPT: Instituto de Pesquisas Tecnológicas

JBIC: Japan Bank of International Cooperation

LA: Licença ambiental

LAl: $\quad$ Licença Ambiental de Instalação

LAO: $\quad$ Licença Ambiental de Operação

LAP: $\quad$ Licença Ambiental Prévia

LI: $\quad$ Licença de Instalação

LO: $\quad$ Licença de Operação

LOP: $\quad$ Licença de Operação Provisória

LP: $\quad$ Licença Prévia

LR: Licença de Regularização

LS: $\quad$ Licença Simplificada

MMA: Ministério do Meio Ambiente

MP: $\quad$ Ministério Público

MTD: $\quad$ Melhor Técnica Disponível

NEPA: $\quad$ National Environmental Politic Act

NOI: $\quad$ Notice of Intent

OECD: $\quad$ Organization for Economic Cooperation and Development

OEMAS: $\quad$ Organizações Estaduais de Meio Ambiente

OMS: $\quad$ Organização Mundial da Saúde

ONGs: Organizações não governamentais

ONU: $\quad$ Organização das Nações Unidas

$\mathrm{PCH}$ : Pequena Central Hidrelétrica

PFM: $\quad$ Policia Florestal Militar

PNMA: $\quad$ Plano Nacional do Meio Ambiente

PNUMA: $\quad$ Programa das Nações Unidas para o Meio Ambiente

PT: $\quad$ Plano de Trabalho 
RAP: $\quad$ Relatório Ambiental Preliminar

RC: $\quad$ Relatório Científico

REAl: $\quad$ Regime de Exercício da Atividade Industrial

RIMA: Relatório de Impacto Ambiental

RMSP: $\quad$ Região Metropolitana de São Paulo

SABESP: $\quad$ Companhia de Saneamento Básico do Estado de São Paulo

SEAQUA: Sistema Estadual de Administração da Qualidade Ambiental, Proteção, Controle e Desenvolvimento do Meio Ambiente e Uso Adequado dos Recursos Naturais

SEBRAE: $\quad$ Serviço Brasileiro de Assistência a Pequena e Média Empresa

SEMA: $\quad$ Secretaria Estadual do Meio Ambiente

SEPA: $\quad$ Scotland Environmental Protection Agency

SIGRH: $\quad$ Sistema Integrado de Gestão de Recursos Hídricos

SILIS: $\quad$ Sistema de Licenciamento Simplificado

SISNAMA: $\quad$ Sistema Nacional do Meio ambiente

TCU: $\quad$ Tribunal de Contas da União

TdRs: $\quad$ Termos de Referência

TRA: $\quad$ Termo de Responsabilidade Ambiental

UEIA Unidade responsável pela análise dos EIAs da Síria

UFESP: $\quad$ Unidade Fiscal do Estado de são Paulo

UNDP: $\quad$ United Nation Development Program

UNEP: $\quad$ United Nation Environmental Program

USEPA: $\quad$ United States Environmental Protection Agency

WII: $\quad$ Wildlife Indian Institute 


\section{INTRODUÇÃO}

A agenda ambiental brasileira tem sofrido grandes transformações, especialmente a partir da segunda metade do século $X X$, quando ocorreram duas conferências mundiais de meio ambiente: a primeira, em 1972, em Estocolmo e a segunda, em 1992, no Rio de Janeiro.

Estes marcantes eventos levaram as economias nacionais a se integrarem cada vez mais na economia global e, para satisfazer aos anseios da sociedade, os meios de produção têm solicitado cada vez mais os ativos ambientais.

A demanda por novos produtos surge ou pela implementação de novas tecnologias ou pela redução das barreiras alfandegárias ao comércio internacional e aos fluxos de novos investimentos.

Tomando como referência o ano de 1960 até os dias atuais, enquanto a economia global quintuplicou, as relações de comércio entre as nações cresceram cerca de catorze vezes (UNEP, 2005).

Por outro lado, cresceu também a desigualdade. Os benefícios do crescimento não têm sido igualmente distribuídos por todos; se por um lado, a renda média global anual per capita supera os US\$ 5.100, por outro lado, 2,8 bilhões de pessoas sobrevivem com uma renda menor que US\$ 2 por dia. Mais grave ainda: $1 \%$ dos mais ricos tem renda maior do que $57 \%$ dos mais pobres (UNEP, 2005).

Não há sinais de que tais parâmetros de desigualdade entre as pessoas e as nações estejam se modificando; há, pois, que diminuir essas desigualdades através da busca do desenvolvimento, e os sociólogos têm procurado expressar essa preocupação da seguinte forma: "não é moralmente correto nem seria factível, na prática, impedir os países em desenvolvimento de se desenvolverem" (GIDDENS, 2009).

Segundo a UNEP (2005), nos últimos 50 anos, os homens alteraram os ecossistemas de maneira que não se encontra precedente em nenhum outro 
período da história; em outras palavras, 60\% dos ecossistemas do planeta foram degradados ou utilizados de maneira insustentável.

A emissão de dióxido de carbono $\left(\mathrm{CO}_{2}\right)$ quadruplicou e os mais recentes relatórios do Internacional Pannel on Climate Changes (IPCC, 2007) demonstram que, em breve, poderá se atingir níveis catastróficos nas mudanças climáticas globais.

A taxa de extinção de espécies é, atualmente, cerca de 1000 vezes maior do que as taxas historicamente conhecidas.

Os compostos de nitrogênio, lançados nos recursos hídricos por efluentes domésticos e industriais não tratados e pelo uso abusivo de fertilizantes, estão criando desertos nos lagos e oceanos.

Metade dos peixes está sendo retirada dos rios além dos limites biológicos e como consequência, suas populações estão diminuindo.

Em 20 anos, se continuar a atual situação, 3,5 bilhões de pessoas estarão vivendo em locais com stress hídrico, isto é, locais com disponibilidade hídrica menor que 1000 metros cúbicos por habitante por ano.

A cada dia, cerca de 6.000 pessoas, a maioria crianças morre por doenças de veiculação hídrica, não tendo acesso em quantidade e qualidade de água potável (UNEP, 2005).

É evidente que parte dos problemas ambientais deriva do crescimento populacional: a população tem crescido 2,5 vezes desde 1950, chegando aos atuais 6,4 bilhões de habitantes e com projeções para o ano de 2050 de acréscimo de outros 2,5 bilhões (UNEP, 2005).

A deterioração ambiental tem preocupado as nações que, por sua vez, têm produzido tratados, procurando definir responsabilidades e procedimentos às questões ambientais.

Assim é que desde o primeiro tratado global, assinado em 1972, na conferência sobre o meio ambiente, realizada em Estocolmo, seguiram-se outros doze, 
assinados pelas diversas nações, objetivando compromissos entre as diversas áreas, tais como: depleção da camada de ozônio, resíduos perigosos, proteção das espécies migratórias.

Em nível regional ou bilateral, cerca de 1000 tratados foram assinados, construindose um enorme e complexo esforço para subsidiar a elaboração de uma legislação internacional (UNEP, 2005).

Os países em geral e o Brasil em particular estabeleceram um arcabouço jurídico extenso, com o objetivo de fazer frente aos enormes desafios para proteger os ativos ambientais, que as pressões pelo desenvolvimento acarretam, e como conseqüência, o acompanhamento das decisões ambientais se iniciou com o tradicional "comando-controle" e atualmente, se alterna para um complexo sistema, que incluem incentivos ou barreiras comerciais do tipo taxas de poluição e barreiras tarifárias de comércio.

Nesse instrumental jurídico-administrativo, as licenças ambientais representam aspecto fundamental a nortear os empreendedores privados e públicos nos seus investimentos, especialmente, os grandes complexos industriais e as obras de infraestrutura.

Os processos de obtenção das permissões ambientais têm sido burocráticos e demorados no dizer de alguns e, rigoroso e necessário no de outros; atrasos em investimentos fundamentais têm sido debitados à demora na obtenção de tais permissões. Associações profissionais têm pressionado fortemente as áreas ambientais para acelerar o processo e as instituições ambientais dos governos alegam deficiência no conteúdo dos processos.

Todos reconhecem que há imperiosa necessidade de proteger os ativos ambientais, mas também que é fundamental acelerar o desenvolvimento econômico como forma de diminuir as desigualdades sociais. 


\section{OBJETIVOS}

Os objetivos desse trabalho podem ser sintetizados em:

- Avaliar as políticas que têm sido implementadas para solucionar os conflitos entre as necessidades de desenvolvimento e a de proteger os diversos ecossistemas;

- Discutir as formas administrativas de emissão de licenças ambientais para aprovar ou vetar investimentos;

- Verificar a eficácia dos procedimentos técnico-administrativos que são empregados para a análise dos empreendimentos que utilizam os ativos ambientais $\mathrm{e}$

- Formular alternativas para que, sem diminuir o rigor das análises ambientais, consiga-se atingir as condições de sustentabilidade com a celeridade necessária para atender aos anseios de desenvolvimento e preservação ambiental.

O trabalho se justifica diante das críticas que o sistema de licenciamento tem recebido dos setores produtivos; dos órgãos do governo; das organizações não governamentais (ONGs); da comunidade acadêmica; dos órgãos defensores da sociedade. Todos se referem às políticas de liberação dos empreendimentos, introduzindo pressões e tensões entre os diversos atores envolvidos.

O que se procurou mostrar é que os processos de licenciamentos ambientais estão contaminados pela ineficiência operacional, necessitando de revisões e aprimoramentos, que conduzam mais segurança aos empreendedores e que também atendam com responsabilidade aos anseios da sociedade de um meio ambiente equilibrado. 


\section{REVISÃO DA LITERATURA}

\subsection{Desenvolvimento Sustentável - Conceito}

O conceito de desenvolvimento sustentável tem ocupado o centro das discussões sobre crescimento econômico e meio ambiente. Por um lado, os desenvolvimentistas priorizam 0 crescimento econômico e por outro, os ambientalistas concentram seus esforços na tentativa de provar que 0 desenvolvimento é um objetivo secundário, podendo ser realizado, mantendo inalteradas as condições ambientais prevalentes.

Na década de setenta, quando os primeiros relatórios do Clube de Roma iniciaram a discussão sobre os limites do crescimento, fez-se uma ampla avaliação sobre a viabilidade do crescimento com objetivo única e exclusivamente econômico.

$\mathrm{Na}$ oportunidade, Ignacy Sachs, consultor da ONU para assuntos de meio ambiente e desenvolvimento, fez a proposta de utilização do termo eco-desenvolvimento, buscando um compromisso entre os meios de produção e o respeito aos ecossistemas, tão necessários às condições de habitabilidade no planeta. Em seu artigo "Sobre a origem, uso e conteúdo do termo sustentável", publicado na revista Ciudades para un futuro más sostenible, José Manuel Naredo (NAREDO, 1996) assevera:

"o êxito da nova metodologia se deveu em boa medida à ambigüidade que o acompanha: se trata de enunciar um desejo tão geral como anteriormente indicado sem precisar muito seu conteúdo e nem o modo de realizá-lo na prática".

Segundo Naredo, o momento atual propicia o caldo de cultura conveniente para o sucesso da utilização da expressão "desenvolvimento sustentável", que vem sendo formulado desde o século XVIII, quando os economistas franceses, chamados de fisiocratas, conclamavam que se deveria "aumentar as riquezas renováveis sem menosprezar os bens primários". 
$\mathrm{Na}$ década de sessenta, Ernst Friedrich Schumacher, autor entre outros de "Small is Beautiful”, que teve grande repercussão no Brasil (DEMBOWSKI, 2003), começou a utilizar o termo "eco-desenvolvimento".

Prossegue Naredo informando que, no âmbito internacional, essa expressão começou a ser utilizada nas conferências que tratavam dos temas de desenvolvimento e meio ambiente e culminou na chamada declaração de Cocoyoc, resultado da conferência patrocinada pelas Nações Unidas, realizada em 1974, em Cuernavaca - México, da qual Sachs participou.

Em sua narrativa, Naredo citando a entrevista de Sachs de 1994, informa que o termo eco-desenvolvimento foi vetado em telegrama enviado ao presidente do Programa das Nações Unidas para o Meio Ambiente - PNUMA, pelo então secretário de Estado, chefe da diplomacia norte-americana Henry Kissinger. Assim, o termo foi substituído por desenvolvimento sustentável, que os economistas mais conservadores poderiam aceitar sem receio, confundindo-o com desenvolvimento auto-sustentado, que havia sido introduzido tempos atrás por Rostow (NAREDO, 1996) e que era utilizado à profusão pelos economistas da época que tratavam do desenvolvimento.

O relatório Brundtland (WECD, 1987) procurou sintetizar o conceito, asseverando que o desenvolvimento econômico deve ser feito sem comprometer o desenvolvimento das futuras gerações.

\subsection{Licenciamento Ambiental no Brasil}

Em 1981, o Brasil editou a lei n 6938, que estabeleceu a política nacional do meio ambiente, que tem no licenciamento ambiental um de seus instrumentos, e especialmente nos seus artigos $9^{\circ}$ e $10^{\circ}$, as condições de sua aplicação.

Assim se expressa a lei:

"Art. 9o- São instrumentos da Política Nacional do Meio Ambiente: 
I. o estabelecimento de padrões de qualidade ambiental;

II. o zoneamento ambiental;

III. a avaliação de impactos ambientais;

IV. o licenciamento e a revisão de atividades efetiva ou potencialmente poluidoras;

V. os incentivos à produção e instalação de equipamento e a criação ou absorção de tecnologia, voltados para a melhoria da qualidade ambiental;

VI. a criação de espaços territoriais especialmente protegidos pelo Poder Público Federal, Estadual e Municipal, tais como áreas de proteção ambiental, de relevante interesse ecológico e reservas extrativistas;

VII. o sistema nacional de informações sobre o meio ambiente;

VIII. o Cadastro Técnico Federal de Atividades e instrumentos de defesa ambiental;

IX. as penalidades disciplinares ou compensatórias ao nãocumprimento das medidas necessárias à preservação ou correção de degradação ambiental;

X. a instituição do Relatório de Qualidade do Meio Ambiente, a ser divulgado anualmente pelo IBAMA;

XI. a garantia da prestação de informações relativas ao Meio Ambiente, obrigando-se o Poder Público a produzi-las, quando inexistentes;

XII. o Cadastro Técnico Federal de atividades potencialmente poluidoras e/ou utilizadoras dos recursos ambientais".

A aplicação do inciso IV - o licenciamento - está explicitada no Art. 10:

"Art. 10 - A construção, a instalação, a ampliação e o funcionamento de estabelecimentos e atividades utilizadoras de recursos ambientais, 
considerados efetiva ou potencialmente poluidores, bem como os capazes sob qualquer forma, de causar degradação ambiental, dependerão de prévio licenciamento por órgãos estaduais competentes, integrantes do SISNAMA e do IBAMA, em caráter supletivo, sem prejuízo de outras licenças exigíveis.

$\S 1^{\circ}$ Os pedidos de licenciamento, sua renovação e a respectiva concessão serão publicados no jornal oficial do Estado, bem como em um periódico regional ou local de grande circulação.

§2ำ Nos casos e prazos previstos em resolução do CONAMA, o licenciamento de que trata este artigo dependerá de homologação do IBAMA.

§3ำ O órgão estadual do meio ambiente e o IBAMA, este em caráter supletivo, poderão, se necessário e sem prejuízo das penalidades pecuniárias cabíveis, determinar a redução das atividades geradoras de poluição, para manter as emissões gasosas, os efluentes líquidos e os resíduos sólidos dentro das condições e limites estipulados no licenciamento concedido.

§4ำ Compete ao IBAMA o licenciamento previsto no caput deste artigo, no caso de atividades e obras com significativo impacto ambiental, de âmbito nacional ou regional."

É interessante observar que os incisos IV e V da Lei - o licenciamento e a absorção de novas tecnologias - estabelecem as condições futuras e fundamentais para a elaboração dos relatórios e dos estudos de impactos ambientais, que representam pré-condições para a análise do processo de licenciamento estabelecido no Art. 10.

Aspecto importante no processo legal é a transferência aos Estados da responsabilidade de licenciar os empreendimentos, ficando ao IBAMA, as funções supletivas e/ou para aqueles empreendimentos de impactos nacionais ou regionais. 
A regulamentação desta lei começou a ser elaborada em 10 de abril de 1989, portanto oito anos após, através do Decreto Federal no 97.632, que se ateve somente ao art. $2^{\circ}$, inciso VIII - plano de recuperação de áreas degradadas, e em 06 de junho de 1990, através do Decreto Federal n 99.274, foi regulamentado o restante da lei.

Nessa regulamentação, no Capítulo IV - Do Licenciamento das Atividades, o Estado estabeleceu as condições para o licenciamento e introduziu o conceito único no mundo, da tripla licença - Art. 19 - conforme segue:

"Art. 19 - O Poder Público, no exercício da sua competência de controle, expedirá as seguintes licenças:

I. Licença Prévia - LP, na fase preliminar do planejamento da atividade, contendo requisitos básicos a serem atendidos nas fases de localização, instalação e operação, observados os planos municipais, estaduais ou federais de uso do solo.

II. Licença de Instalação - LI, autorizando o início da implantação, de acordo com as especificações constantes do Projeto Executivo aprovado; e

III. Licença de Operação - LO, autorizando, após as verificações necessárias, o início da atividade licenciada e o funcionamento de seus equipamentos de controle de poluição, de acordo com o previsto nas Licenças Prévia e de Instalação.

$\S 1^{\circ}$ Os prazos para concessão das licenças serão fixados pelo CONAMA, observada a natureza técnica da atividade.

§2 Nos casos previstos na resolução do CONAMA, o licenciamento de que trata este artigo dependerá da homologação do IBAMA.

§3ํ Iniciadas as atividades de implantação e operação, antes da expedição das respectivas licenças, os dirigentes dos 
Órgãos Setoriais do IBAMA deverão, sob pena de responsabilidade funcional, comunicar o fato às entidades financiadoras dessas atividades, sem prejuízo da imposição das penalidades, medidas administrativas de interdição, judiciais, de embargo, e outras providências cautelares.

$\S 4^{\circ}$ Os licenciamentos dos estabelecimentos destinados a produzir materiais nucleares ou a utilizar a energia nuclear e suas aplicações, competirá à Comissão Nacional de Energia Nuclear - CNEN, mediante parecer do IBAMA, ouvidos os órgãos de controle ambiental estaduais e municipais.

§5 Excluída a competência de que trata o parágrafo anterior, nos demais casos de competência federal, O IBAMA expedirá as respectivas licenças, após considerar 0 exame técnico procedido pelos órgãos estaduais $\mathrm{e}$ municipais de controle da poluição."

Para análise das variáveis ambientais que norteiam o licenciamento com sua base legal, pode-se estabelecer a seguinte cronologia (Tabela 3.1): 
Tabela 3.1 - Cronologia da base legal do licenciamento ambiental

\begin{tabular}{l|l|l}
\hline Base Legal & Data & Instrumento ambiental \\
\hline Lei 6938 & Agosto 1981 & $\begin{array}{r}\text { Art.9 III - AIA } \\
\text { IV -Licenciamento } \\
\text { V - Tecnologia } \\
\text { Art.10 Licenciamento }\end{array}$ \\
\hline Resolução CONAMA 1 & Janeiro 1986 & EIA-RIMA \\
\hline Constituição Federal & Outubro 1988 & $\begin{array}{l}\text { Art. 23 - Competência Concorrente } \\
\text { Art. 225 - IV: significativa degradação - } \\
\text { Estudo Prévio de Impacto Ambiental }\end{array}$ \\
\hline Decreto Federal no 99.274 & Junho 1990 & LP,LI, LO \\
\hline Resolução 237 & Dezembro 1997 & O anexo define a lista de atividades. \\
\hline
\end{tabular}

Legenda: AIA - Avaliação de Impacto Ambiental

LP - Licença Prévia

LI - Licença de Instalação

LO - Licença de Operação

O conceito de licenciamento ambiental somente é tratado na resolução $237 / 97$ e nos seguintes termos:

"Art.1 -

I. Licenciamento Ambiental: procedimento administrativo pelo qual o órgão ambiental competente licencia a localização, instalação, ampliação e a operação de empreendimentos e atividades utilizadoras de recursos ambientais consideradas efetiva ou potencialmente poluidoras ou daquelas que, sob qualquer forma, possam causar degradação ambiental, considerando as disposições legais e regulamentares e as normas técnicas aplicáveis ao caso.

II. Licença Ambiental: ato administrativo pelo qual o órgão ambiental competente, estabelece as condições, restrições e medidas de controle ambiental que deverão ser obedecidas pelo empreendedor, pessoa física ou jurídica, para localizar, instalar, 
ampliar e operar empreendimentos ou atividades utilizadoras dos recursos ambientais consideradas efetiva ou potencialmente poluidoras ou aquelas que, sob qualquer forma, possam causar degradação ambiental."

O processo de licenciamento ambiental tem suscitado grandes discussões quanto aos agentes envolvidos, especialmente quando ele é analisado à luz do Artigo 225 da Constituição Federal, que incumbe ao Poder Público, o dever de defender o meio ambiente, bem comum de todos.

Há, pois, a competência concorrente entre os entes da Federação na defesa do meio ambiente.

Este fato propicia que um ente invoque a sua competência para licenciar no lugar de outro, o que acarreta um processo de desgaste e grandes atrasos nos trabalhos e não raro enseja a provocação da intervenção do Poder Judiciário no processo.

A propósito, Patrícia Azevedo Silveira apud Trennepohl; Trennepohl (2008) afirma: "não há nada mais difícil e pouco tratado em matéria de Direito Ambiental como a divisão de competências em matéria administrativa."

Sobre o mesmo tema, Freitas (2005) informa:

“Há - é inegável - disputa de poder entre órgãos ambientais, fazendo com que, normalmente, mais de um atribua a si mesmo competência legislativa e material. Há também, uma controvérsia histórica que jamais desaparecerá: o poder central está distante e desconhece os problemas locais; o poder local está mais próximo dos fatos, porém é influenciado e envolvido nos seus próprios interesses".

Em direção análoga, Fink, D; Junior Hamilton, A; Dawalibi, M. (2002) analisam o conflito de competência sobre o licenciamento: "isto porque a experiência mostra que todos querem licenciar determinados empreendimentos. Outros, ninguém se habilita. Politicamente, por vezes, uma atividade é interessante. Outras representam um ônus sem retorno." 
Esses conflitos geram incertezas que estão a exigir, por parte do administrador público, não só competência técnica para decidir, mas principalmente habilidade política para tomar as decisões que melhor atendam à sociedade, vez que ela será, em última análise, a mais prejudicada, quer por não ter os empreendimentos necessários à produção de bens e serviços, ou por ter um empreendimento insustentável do ponto de vista ambiental, mas que pelas conveniências ou vieses políticos, acaba sendo executado; outros, pelas mesmas razões, mas de inegável valor social, deixam de ser realizados, como alguns sistemas de captação de água da Região Metropolitana de São Paulo (RMSP).

O Artigo 23 da Constituição Federal assim se expressa: "É competência comum da União, dos Estados, do Distrito Federal e dos Municípios:

VI. proteger o meio ambiente e combater a poluição em qualquer de suas formas; ;...

Parágrafo único: Lei complementar fixará normas para a cooperação entre a União e os Estados, o Distrito Federal e os Municípios, tendo em vista o equilíbrio do desenvolvimento e do bem-estar em âmbito nacional."

É necessário dirimir no âmbito legislativo, a controvérsia legal para se abstrair a variável aleatória da competência legal no processo de licenciamento ambiental.

Para tanto, há no Congresso Nacional projeto de lei (PL no 388/2007), que objetiva definir com maior clareza as competências estabelecidas no Art. 23 da Constituição Federal.

Fink, D; Junior Hamilton, A; Dawalibi, M. (2002) defendem ainda que, tendo a resolução 237/97 definido o licenciamento ambiental e estabelecido os procedimentos administrativos para sua obtenção, ela representa importante passo na direção de que "o maior esforço é conciliar desenvolvimento econômico e preservação ambiental, ambos de vital importância para a população."

A crítica que tem sido constante nos processos de licenciamento ambiental está centrada na discricionariedade do processo; os agentes públicos introduzem 
entraves burocráticos desnecessários e análises técnicas questionáveis. Há, também, consenso que é necessário introduzir maior segurança no processo de análise dos licenciamentos, sem, no entanto, subtrair a autonomia de cada ente federativo e com isso se aprimorar o sistema preventivo, cujo instrumento fundamental é a análise criteriosa e a avaliação adequada e competente dos impactos ambientais que ocorrerão.

Essa não é uma tarefa fácil, vez que muitas são as variáveis que interferem nas reações que ocorrem no meio ambiente, e sobre elas, ainda há um profundo desconhecimento da ciência, que torna difícil conseguir respostas objetivas, o que significa que os riscos devem ser gerenciados.

A este propósito, após algumas análises estatísticas com parâmetros obtidos no Estado de São Paulo, assim se expressa Ferraz (2007):

"A implementação apropriada de políticas públicas numa democracia depende dos incentivos oriundos da classe política para escolher políticas e incentivos que serão implementados pela burocracia do Estado. A contabilidade política da reeleição criou incentivos para os políticos atuarem com interesses eleitorais, mas por outro lado, podem também motivá-los a escolher políticas que são excessivamente populares. Por outro lado, se a burocracia for politicamente controlada pelos políticos, eles podem implementar políticas ineficientes, motivadas unicamente por interesses eleitoreiros."

Mais adiante, analisando os resultados das análises estatísticas elaboradas para o Estado de São Paulo, onde o parque industrial é maior, relata Ferraz (2007): "eu encontrei sugestiva evidência que os burocratas são influenciados por interesses eleitorais. O número de aprovações de licenças ambientais em anos eleitorais cresce significativamente de acordo com os interesses eleitorais. Em anos de eleições para prefeitos, há maior número de licenças objetivando inaugurações de obras e por conseqüência, o início de operação de empreendimentos especialmente nos municípios em que os prefeitos pertencem ao mesmo partido do governador. Em anos onde a eleição é para o governo do Estado, há mais licenças aprovadas 
nos municípios onde os governadores tenham larga margem de vitória prevista nas pesquisas das eleições. Este é um fato comprovado por modelos estatísticos."

É necessário analisar os instrumentos das políticas ambientais, de forma a que se obtenha dentro dos princípios da participação democrática, o equilíbrio entre as variáveis políticas, que as instituições democráticas pressupõem, e a competente análise técnica, isenta e eficiente, que o meio ambiente necessita, objetivando um efetivo crescimento econômico, que deverá propiciar a redução das desigualdades sociais com sustentabilidade ambiental.

Os instrumentos fundamentais que devem nortear as decisões na área ambiental são: a avaliação dos seus impactos (Lei 6938 Art.9-III) e o licenciamento e a revisão de atividades efetiva ou potencialmente poluidoras (Lei 6938 Art.9º-IV).

\subsection{Avaliação dos Impactos Ambientais (AIA) - Experiência Internacional}

Os estudos de avaliação dos impactos ambientais se originaram nos Estados Unidos na década de 1970, e logo foram adotados em alguns países como: Austrália, Canadá, Nova Zelândia. Os conceitos básicos ali definidos ainda hoje são aplicáveis.

A lei NEPA (National Environmental Politic Act) dos Estados Unidos traz como instrumento mais importante uma proposta de análise sistêmica para se procurar prevenir os impactos sobre o meio ambiente. É o embrião do sistema de avaliação de impactos ambientais (MAC DONALD, 1998).

Mais tarde, ainda na década de 1970, foram introduzidas em outros países, novas e mais avançadas análises técnicas, como por exemplo, avaliação de risco, consideração dos impactos sociais, audiências públicas e a procura de processos tecnológicos mais avançados.

A avaliação dos impactos tornou-se mais rigorosa a partir dos anos 1980 e início de 1990, quando foram realizadas revisões metodológicas no processo, utilizando a experiência adquirida anteriormente. 
Tais revisões se referiam aos desenvolvimentos científicos e institucionais; a interrelação da AIA com outros processos, tais como estudos de viabilidade e usos e ocupação do solo, e, incorporação dos efeitos cumulativos das mudanças dos ecossistemas; do monitoramento e da experiência adquirida.

Diversos outros países começaram a adotar a AIA: Canadá em 1973, Austrália em 1974, Nova Zelândia em 1974, França em 1976, Alemanha em 1976, Holanda em 1979, Inglaterra em 1979 (WOOD, 1995). Nesta mesma época, a comunidade européia e o Banco Mundial estabeleceram a AIA como pré-condição para obtenção dos financiamentos.

$\mathrm{Na}$ América Latina, diversos países se sensibilizaram com a causa ambiental e começaram a sistematizar e introduzir as avaliações de impactos ambientais como pré-condição para a aprovação de empreendimentos utilizadores dos ativos ambientais: Venezuela em 1976, Brasil em 1981, México em 1982, Peru em 1990, Bolívia em 1992, Uruguai em 1994 e Chile em 1994 (GEORGE; LEE, 2000).

\subsubsection{A evolução do sistema}

Segundo Sadler (1996), a evolução do sistema de avaliação ambiental pode ser sintetizada na tabela 3.2 : 
Tabela 3.2 - Evolução da avaliação ambiental

\begin{tabular}{|c|c|}
\hline Período & Aspectos da Inovação \\
\hline Antes de 1970 & $\begin{array}{l}\text { - Projetos analisados segundo aspectos técnico-econômicos; } \\
\text { - Pouca consideração às questões ambientais. }\end{array}$ \\
\hline $1970-1975$ & $\begin{array}{l}\text { - NEPA - Introduz avaliação ambiental; } \\
\text { - Princípios da participação popular; } \\
\text { - Estabelecimento de exigências; } \\
\text { - Estabelecimento de padrões para análise dos impactos; } \\
\text { - Vários países implementam as AIAs; } \\
\text { - Maiores incentivos à participação popular. }\end{array}$ \\
\hline $1975-1980$ & $\begin{array}{l}\text { - Formulação de regulamentações; } \\
\text { - Incorporação da AIA em países em desenvolvimento; } \\
\text { - Incorporação da Avaliação Ambiental Estratégica e Análise de } \\
\text { Riscos; } \\
\text { - Ênfase em modelagem matemática, previsão e avaliação; } \\
\text { - Incorporação da participação da sociedade no EIA. }\end{array}$ \\
\hline $1985-1990$ & $\begin{array}{l}\text { - Comunidade Européia estabelece os princípios básicos e sistemas } \\
\text { de AIA nos estados membros; } \\
\text { - Incorporação de impactos cumulativos; } \\
\text { - Mecanismos de monitoramento (monitoramento, auditoria, gestão } \\
\text { dos impactos); } \\
\text { - Agências Internacionais de financiamento exigem EIA para } \\
\text { aprovação de projetos. }\end{array}$ \\
\hline Década de 90 & $\begin{array}{l}\text { - Alguns países estabelecem Sistema de Avaliação Estratégica; } \\
\text { - Incentivo ao uso de Tecnologias de Informação; } \\
\text { - EIA é utilizado em projetos e atividades de desenvolvimento } \\
\text { internacionais; } \\
\text { - Crescimento da capacitação na elaboração de EIA, redes de apoio } \\
\text { e cooperação. }\end{array}$ \\
\hline
\end{tabular}

Fonte: Sadler (1996) 
E no momento atual, em que a sustentabilidade é pré-condição, as análises se tornam mais abrangentes e se encaminham para as Avaliações Ambientais Estratégicas (AAE) - aplicadas aos planos resultantes das políticas públicas.

A inclusão das AIA e AAE como práticas rotineiras tem sido aplicada nos países europeus e em diversos países em vias de desenvolvimento. A seguir, serão descritas experiências dos países que se destacaram na área do licenciamento ambiental no contexto do continente em que estão inseridos.

\subsubsection{Continente Africano e Oriente Médio}

\subsubsection{Egito}

Até fins da década de 1970, o Egito seguia os princípios de uma regulação fixa, onde se estabeleciam padrões para diferentes condições de utilização dos recursos naturais.

Após as Conferências de Meio Ambiente de Estocolmo e Rio de Janeiro e com as pré-condições exigidas pelas agências internacionais de financiamentos para os empreendimentos que utilizam recursos naturais, as autoridades políticas procuraram adotar os modelos europeu e americano.

Houve forte reação da indústria com a introdução do sistema comando-controle adotado na época, e que exigia a busca de conformidade dos processos com os novos e mais rígidos padrões.

Não obstante, o surto de desenvolvimento que ocorreu na década de 1970, decorrente do conflito de 1967, foi um facilitador, pois, estimulando o investimento externo, tornou menos resistentes os questionamentos internos.

Somente em 1982, foi criada a Agência Egípcia Ambiental (Egyptian Environmental Affair Agency) - EEAA, o que propiciou que na década seguinte, houvesse a transformação do conceito então predominante de zero crescimento para o de desenvolvimento sustentável, segundo expresso no relatório Brundtland. 
Por outro lado, neste período, o rápido crescimento populacional e a urbanização crescente exerciam grandes pressões sobre os limitados recursos naturais do Egito.

Assim, diversos planos ambientais começaram a ser implementados, como o Plano de Ação da Agência Ambiental em 1992, e diversos outros diplomas legais editados entre 1994 e 1997, especialmente, a Lei o 4 de 1994, que estabeleceu os limites da autoridade da EEAA para regular a poluição do ar; controlar e gerenciar resíduos inclusive os perigosos e controlar as descargas dos efluentes no mar.

O seu regulamento de n $338 / 1995$ estabeleceu quatro pontos principais:

- Tornou a Agência Ambiental como a responsável total pela coordenação e gerenciamento dos negócios ambientais;

- Reconheceu os problemas de poluição do ar e editou o primeiro regulamento para controle das emissões gasosas no Egito;

- Estabeleceu o gerenciamento costeiro, de forma clara, quando verificou e reconheceu os grandes problemas da poluição das águas do mar e do solo;

- Introduziu o sistema de licenciamento para o manejo de resíduos perigosos, bem como para seu tratamento e disposição final.

O ponto central dos problemas ambientais no Egito estava em se atingir um nível de desenvolvimento com responsabilidade ambiental e para tanto, seriam necessárias diversas ações, tais como:

- Comprometimento dos governos em estimular a eficiência nas indústrias, utilizando os conhecimentos científicos e as melhores informações disponíveis;

- Reconhecimento da importância de se utilizar os critérios ambientais para propiciar melhores condições de bem estar das populações;

- Estabelecimento do responsável pela poluição e pela degradação dos recursos naturais e transferência dos custos e das conseqüências dessa degradação para ele: "se o poluidor, ou em última análise, o 
consumidor é obrigado a pagar, então o custo da poluição é transferido ao custo do produto final (WAHAAB, 2003).

A partir dessa constatação, houve uma grande discussão entre políticos e empresários no sentido de responsabilização dos últimos pela poluição e se percorreu um longo caminho de negociações, procurando incentivar o uso de novas tecnologias para a prevenção da poluição, para a minimização de resíduos e para a utilização do ciclo de vida dos materiais.

A partir de 1990, começou a ser utilizado o conceito de análise de risco, que passou a ser ferramenta diferenciadora para autorização de utilização dos ativos ambientais.

Os setores industriais se organizaram e criaram o Conselho Empresarial para o Desenvolvimento Sustentável, que em conjunto com a Câmara de Comércio Internacional, editaram em 1997, o Manual Empresarial para o Desenvolvimento Sustentável, procurando estimular a importância da questão ambiental nas empresas.

Em paralelo, procurou-se mostrar a importância, para imagem das empresas, de terem seus produtos identificados como produzidos de forma ambientalmente adequada, o que em muito acrescia à sua competitividade, reduzia custos, mas, para tanto, havia necessidade de aprimoramento na produção, introduzindo-se os conceitos de análise do ciclo de vida dos produtos e auditorias ambientais, à semelhança do que ocorria em outras indústrias no mundo.

A Lei no 4 estabeleceu a necessidade de elaboração do EIA a partir de 1995 e definiu o nível de estudo para três categorias, baseadas em diferentes tipos de empreendimentos:

- Lista branca: projetos de menor impacto;

- Lista cinza: para aqueles que apresentam substancial potencial de impacto;

- Lista preta: os que requerem EIA completo, devido ao grande potencial de impacto ambiental. 
Apesar dos esforços, percebe-se que existem severas limitações no uso do EIA como instrumento da boa prática da política ambiental no Egito.

A capacitação técnica dos funcionários da EEAA tem se constituído em um fator limitante de grande importância já que ela é a única autoridade revisora.

Seria adequado que os processos de análise fossem ampliados, utilizando as Universidades, o que aumentaria a confiabilidade e a transparência do processo do EIA.

Outra crítica é que o EIA se limita somente ao empreendimento, e muitas vezes, seus impactos não se restringem a ele, mas afeta também aos que estão inseridos nas vizinhanças.

Foram estabelecidos os seguintes critérios para a aceitação e aprovação do EIA:

- Uso e ocupação do solo: os impactos do uso do solo estão intimamente correlacionados com os impactos de vizinhança e seus efeitos econômicos. O tema está relacionado aos efeitos na comunidade, sua realocação e os problemas econômicos decorrentes deste ato.

- Efeitos sociais: a avaliação dos impactos sociais e econômicos é parte importante no relatório. Está muito correlacionada com o impacto de uso e ocupação do solo e ao desenvolvimento econômico.

- Efeitos econômicos: indicadores econômicos devem ser desenvolvidos e são muito similares aos do desenvolvimento sustentável, tais como:

- Emprego e renda;

- Impostos, receitas e despesas;

- Valor da terra;

- Existência ou não de comunidade empresarial.

Os critérios de preservação do meio ambiente físico são divididos em: 
- Preservação do patrimônio histórico e arqueológico: tem por objetivo proteger os sítios históricos e arqueológicos da destruição física, da poluição visual, atmosférica, e outros elementos que possam descaracterizar tais sítios ou alterar seu conjunto;

- Qualidade do ar, da água, do solo e ruído: formam um conjunto de leis para evitar a poluição do ar, da água, do solo e a emissão de ruídos. Essas mesmas leis protegem o meio ambiente dos resíduos perigosos, materiais tóxicos e estabelecem padrões para a utilização e transporte seguro desses materiais;

- Saúde pública, vegetação e vida selvagem: inclui os padrões para proteção à saúde pública, à segurança no trabalho e riscos inerentes; às espécies ameaçadas e às em extinção.

No âmbito político, a EEAA deve preparar, anualmente, o relatório do Estado do Meio Ambiente, que é apresentado ao Presidente, aos Ministros e ao Congresso Nacional.

Esse relatório procura abordar o estado atual e os principais problemas encontrados nos diversos ativos ambientais: recursos hídricos, solo, atmosfera, etc.

É um relatório que analisa esses aspectos nas diversas regiões do país, e serve como parâmetro para as análises de futuros EIAs e para formar um banco de dados, que alimenta um modelo matemático, para prever possíveis impactos nas implementações dos futuros empreendimentos.

Os instrumentos legais de proteção ao meio ambiente no Egito são relativamente novos e estão baseados, principalmente, em sanções às atividades poluidoras. Os valores dos padrões são os adotados em outros países.

A crítica que se faz a esse procedimento é que nem sempre tais padrões admitem a necessária flexibilidade para a Agência Governamental negociar um rápido acordo com os poluidores para ajustamentos. 
As Agências Egípcias informam aos poluidores as violações aos padrões, mas não há previsão legal para a implantação das medidas mitigadoras, não há também um acompanhamento após a aprovação e implementação do projeto.

Esse fato retira do instrumento EIA uma ferramenta efetiva de servir de critério para os outros na direção de assegurar a sustentabilidade efetiva do projeto.

Um aspecto que chama a atenção na gestão ambiental praticada no Egito está relacionado com as políticas de controle das indústrias de importância estratégica, como a metalúrgica, a de alumínio, a têxtil e uma multinacional de bebidas refrigerantes.

São indústrias que ali se caracterizam por baixa taxa de retorno dos investimentos, mas de utilização intensiva de mão-de-obra.

Segundo Wahaab (2003), "Aplicar os regulamentos vigentes a essas indústrias não vai salvar o meio ambiente, enquanto que o seu fechamento irá criar outros tipos de tensões sociais e políticas".

Na realidade, o que se conclui é que o Egito, não obstante seu enorme patrimônio histórico e cultural, tem um sistema de gestão ambiental extremamente frágil, ainda que esteja realizando esforço extremo para se ajustar aos caminhos de sustentabilidade para o seu desenvolvimento.

Objetivando caminhar nessa linha, devem ser destacados alguns problemas:

- "O imperativo de rápido desenvolvimento social e econômico pode influenciar os políticos, no sentido de implementar e reforçar políticas e leis ambientais apropriadas;

- A necessidade de desenvolvimento freqüentemente define os limites dos recursos ambientais disponíveis;

- As agências ambientais sempre operam com severas restrições de recursos; 
- O público, devido ao escasso conhecimento, não percebe a urgência do problema ambiental e deixa de contribuir para alavancar as pressões políticas para implementar as ações legislativas, para criar condições de desenvolvimento sustentável;

- O desejo de satisfazer as necessidades sociais básicas ultrapassa as considerações ambientais." (WAHAAB, 2003).

Para novos empreendimentos industriais, O EIA deve enfatizar as medidas preventivas, especialmente analisando as condições de biodegradação e os impactos toxicológicos dos novos compostos sintéticos comumente usados na produção industrial, e eles devem ser identificados, relacionados e rotulados. Padrões máximos para esses poluentes devem ser incluídos na lei ambiental.

As melhores tecnologias disponíveis devem ser utilizadas nesses novos empreendimentos, especialmente para o controle das emissões de gases, uma vez que, atualmente, o Egito não as utilizam devido aos custos elevados, ficando em incômoda situação de permitir a operação com equipamentos obsoletos, o que agrava os problemas de poluição que não se deseja aceitar.

Em análise final, conclui-se que há elementos de conhecimento dos avanços de tecnologias de gestão ambiental, mas não há ambiente político e comprometimento satisfatório para sua implantação.

\subsubsection{Sudão}

Para a aplicação efetiva da Avaliação de Impacto Ambiental - AIA - no Sudão, Ali (2003) identificou as seguintes dificuldades principais:

- Aspectos relativos à legislação;

- Identificação tardia da necessidade da AIA no ciclo do projeto;

- Tempo inadequado para a execução da AIA;

- Composição e qualificação da equipe que elabora a AIA; 
- Foco na elaboração da AIA.

Para mitigar os efeitos que tais dificuldades podem acarretar, três áreas precisam ser fortalecidas: legislação, treinamento e cooperação internacional.

Não obstante, Moghraby (1997) advoga que tenha sido o Sudão o primeiro país no mundo em desenvolvimento a implementar uma AIA ainda no ano de 1954, no Projeto Nilo Equatorial: "foi uma AIA na função ainda que não no nome".

O Sudão tem seus maiores projetos, especialmente de infra-estrutura, executados através de financiamentos externos e as agências financiadoras têm solicitado estudos de impacto ambiental, especialmente a Alemanha.

Mais recentemente, o parlamento sudanês elaborou uma lei, denominada Política de Proteção Ambiental, que estabelece: "qualquer projeto de desenvolvimento de grande porte, cuja construção possa vir a impactar negativamente a qualidade do meio ambiente, deve apresentar um Estudo de Viabilidade Ambiental" (MOGHRABY, 2003).

Neste estudo, o empreendedor deve considerar os seguintes aspectos:

- Efeitos no meio ambiente do projeto ou ação proposta;

- Qualquer inevitável impacto negativo no meio ambiente;

- Alternativas viáveis para as ações propostas.

Os objetivos da AIA para a previsão dos impactos negativos e também da sua mitigação, não raro são frustrados, porque nem sempre são feitos com a antecipação devida.

Há casos em que os estudos foram desenvolvidos 16 anos após a conclusão dos serviços, tornando-se um procedimento absolutamente inócuo do ponto de vista ambiental.

A participação popular e das ONGs tem sido de fraca intensidade, embora sua atuação seja desejável para garantir a incorporação nos projetos, dos aspectos que a comunidade interpreta como importantes. 
Há falta de uma agência ambiental no Sudão, que possa acompanhar as prescrições da AIA, e essa é a principal dificuldade que o sistema enfrenta.

Para sanar esses problemas, Moghraby sugere as seguintes medidas:

- O país deve caminhar rapidamente para a adoção de um Plano Nacional de Meio Ambiente e na implementação de uma Agência Ambiental;

- Empresas qualificadas, instituições e profissionais devem estar envolvidos nas AIAs;

- A qualidade das AIAs deve acompanhar as recomendações da norma ISO 14.001;

- Os manuais e softwares utilizados nas AIAs devem estar disponíveis em inglês, e se possível em linguagem árabe;

- Os manuais e softwares devem levar em conta as circunstâncias sudanesas ou de países com grau de desenvolvimento similar;

- O Comitê de Altos Estudos Ambientais e de Recursos Naturais, criado em 1992, deve ser institucionalmente prestigiado e ter orçamento compatível;

- Institutos de pesquisas, como o Instituto para Estudos Ambientais, devem focar seus trabalhos na elaboração de AIAs no Sudão;

- A participação popular deve ser parte integrante da AIA;

- AIAs devem ser abertas à competição entre empresas de consultoria, através de convites para licitação;

- Deve ser obrigatório que empresas de consultorias estrangeiras incorporem em suas equipes, consultores sudaneses, para melhorar a capacitação técnica interna;

- Deve haver tempo suficiente entre a elaboração das AIAs e a execução efetiva dos projetos; 
- Aspectos sociais e econômicos devem receber o mesmo peso que os ambientais nas avaliações".

\subsubsection{Yemen}

Trata-se de um projeto de uma estrada de $311 \mathrm{Km}$ de extensão, a rodovia Safir Hadramout, que atravessa a parte central do país, e para financiá-lo, o BIRD incorporou ao empréstimo, a obrigação de elaboração da AIA.

Esta rodovia objetiva conectar a parte oriental do país com a capital Sana'a e propiciar o desenvolvimento da indústria petroleira, bem como a interligação de importantes centros agrícolas, turísticos e culturais, que estão localizados ao longo do empreendimento.

As premissas básicas do estudo determinaram as condições mínimas para avaliar, reduzir e prevenir os efeitos diretos, indiretos ou cumulativos nos ambientes biofísicos, sociais e culturais, considerando também a conservação dos sítios de valor arqueológico e histórico. Importante ressaltar que o estudo definiu também o plano de gestão e monitoramento ambiental durante a fase construtiva e de operação da rodovia (BASAHI, 2003).

A institucionalização da questão ambiental no Yemen ocorreu a partir de 1990, quando o país foi unificado. Antes disso, as legislações eram dispersas nos dois países.

Foi criado um Conselho de Proteção Ambiental (Environmental Protection Council EPC), com a responsabilidade de propor leis e padrões ambientais. Em 1993, após aprovação no Gabinete de Ministros e no Parlamento, foi editada a lei de proteção ambiental, e em 1996, foi aprovada a lei sobre a Política de Avaliação dos Impactos Ambientais para a República do Yemen.

Paralelamente às tramitações legais por exigência dos agentes financeiros, a AIA teve seu desenvolvimento normal e levou em consideração importantes e singulares aspectos, tais como: 
- Descrição geológica, hidrologia e qualidade das águas superficiais e subterrâneas, intensidade das chuvas e inundações, áreas de recarga de aqüíferos, salinidade dos solos;

- Meio biológico, cobrindo os mais importantes e sensíveis ecossistemas, e rotas de migração de animais selvagens e rebanhos (camelos, cabras, e ovelhas), locação de áreas de pastagens;

- Meio cultural e social, englobando os aspectos da distribuição das populações, estrutura comunitária, tribos, posse da terra, assentamentos existentes, infra-estrutura e serviços, saúde pública e emprego;

- Sítios históricos e arqueológicos, abrangendo períodos pré-históricos e históricos remanescentes. Importante salientar que esses trabalhos foram desenvolvidos em duas fases: a primeira, com duração de 15 dias, foi de reconhecimento da extensão total da estrada; e a segunda, também com 15 dias, destinou-se a identificar e projetar a proteção dos bens arqueológicos encontrados, com a aprovação das autoridades do Yemen;

- Determinação do potencial direto e indireto dos impactos do projeto, observando as manifestações dos grupos sociais afetados, das autoridades do governo e das ONGs;

- Desenvolvimento de um plano de gestão ambiental, recomendando medidas viáveis do ponto de vista ambiental e econômico, com o objetivo de prevenir e/ou reduzir os impactos negativos e aumentar os positivos;

- Desenvolvimento de um plano de monitoramento, analisando a eficiência das medidas mitigadoras durante a fase de construção e operação.

É bastante elucidativa a abordagem dos estudos ambientais no que concerne a sítios arqueológicos, que são importantes e extensos naquela região.

Foi adotada a seguinte metodologia de análise (BASAHI, 2003). 
- Primeiro estágio - antes do levantamento no campo

Foi feita na área do projeto, uma consistente análise da literatura publicada, bem como de documentos pré-historicos relevantes, mas não publicados.

Foram inspecionados na biblioteca de Sana'a, pela Organização dos Museus de Antiguidades e Manuscritos, os materiais arquivados, incluindo artefatos e manuscritos.

- Segundo estágio - levantamento no campo

$\mathrm{Na}$ área do projeto, foi feito um intensivo estudo, objetivando locar e avaliar sítios pré-históricos e arqueológicos ao longo da faixa de domínio da estrada. Identificados os sítios, eles foram cuidadosamente locados, usando-se o Global Positioning System (GPS).

Artefatos recolhidos foram catalogados; identificados com etiquetas e encaminhados para análises laboratoriais.

- Terceiro estágio - Teste de campo

Completada a identificação e a catalogação nos limites da região teste, o procedimento foi repetido para todos os sítios com probabilidade de ocorrência de material de valor histórico.

Os locais foram estudados, utilizando critérios científicos, para verificar a consistência das ocorrências, bem como o interesse regional, cultural e científico para pesquisas.

- Quarto estágio - Preparação do relatório

Nesta fase, foi elaborado o relatório arqueológico do material recolhido. Nele, estão incluídas a descrição do material encontrado em cada sítio e uma avaliação da sua significância do ponto de vista arqueológico. 
Também foram analisados os possíveis impactos que o projeto poderia ter nos diferentes sítios, bem como as devidas recomendações para preservação.

No caso específico, foram encontrados 35 sítios arqueológicos pertencentes à idade de bronze, ao sul árabe, ao islamismo e aos modernos beduínos.

As ações foram classificadas como:

- Nenhuma ação;

- Evitar as áreas rochosas de valor histórico;

- Proteção por cercamento;

- Relocação do projeto no trecho;

- Monitoramento durante a construção através da Organização Geral dos Manuscritos e Museus;

- Preparação de plantas detalhadas antes da construção para futuras informações.

Os trabalhos de campo também identificaram 50 sítios pré-históricos pertencentes ao paleolítico inferior, ao médio paleolítico, ao alto paleolítico e ao neolítico da idade do bronze. Estes estudos mostraram que 78 por cento dos sítios estavam locados em quatro trechos da rodovia e que materiais rochosos desses locais não poderiam ser utilizados para sua construção, o que possibilitaria a exploração arqueológica no futuro.

No plano de gerenciamento ambiental, foram alocados recursos para se aprofundar os estudos através da associação entre paleogeomorfologistas e os especialistas em pré-história.

Também houve a recomendação de ações para considerar os impactos sociais, que resultariam da construção da rodovia, estimulando a criação de oportunidades de emprego e reduzindo a possibilidade de fragmentação social dos grupos locais. 
Ao concluir, as principais recomendações foram no sentido que os custos da elaboração dos estudos ambientais estivessem integrados aos custos totais do financiamento, enfatizando que deveriam estar disponíveis nas primeiras fases de desenvolvimento do projeto.

Mesmo que os padrões e as políticas ambientais não estejam formalmente estabelecidos no Yemen, as experiências adquiridas nesse projeto foram úteis para outros países em desenvolvimento (BASAHI, 2003).

A abordagem dos projetos ambientais pressupõe que consultores com larga experiência sejam envolvidos na preparação dos estudos, inclusive nas análises de campo. Também é importante a experiência dos técnicos locais, e é imprescindível o comprometimento das autoridades dos diversos órgãos que tem responsabilidade na gestão dos recursos naturais que serão utilizados.

Os estudos mostraram que essa cooperação levou a alterações no projeto inicial, modificando alguns trechos do traçado e com isso foram protegidas áreas do patrimônio histórico nacional, que poderiam ter sido danificadas, causando grande perda ao país.

\subsubsection{Gana}

Nesta parte da África, os estudos ambientais procuram estimular enfaticamente a participação da população.

No desenvolvimento dos estudos ambientais, é absolutamente fundamental a participação popular, especialmente daqueles indivíduos que serão diretamente afetados pelos empreendimentos. Quanto mais cedo a população puder se manifestar, tanto melhor para o desenvolvimento dos trabalhos.

Analisar os contornos e a importância dessa participação constitui boa prática para que a tomada de decisão política atenda as expectativas da população, sem perder a consistência técnica das análises. 
Assim, normalmente, a população é convocada, com 21 dias de antecedência, através de jornais de grande circulação na região.

No período de 1995 a 1997, do total de 72 Estudos de Impactos Ambientais elaborados, 8 foram objeto de audiências públicas (APPAH-SAMPONG, 2003).

Os procedimentos adotados para a audiência pública podem ser sintetizados em:

- Introdução dos panelistas participantes, líderes regionais, líderes do executivo regional, grupos de representantes da comunidade, organizações não governamentais;

- Os objetivos da audiência são explicados com clareza para a população presente;

- Os empreendedores explanam o projeto, em linguagem clara e que facilite o entendimento por parte da população. São mostrados os impactos negativos e os benefícios esperados do empreendimento, assim como as medidas mitigadoras;

- Os representantes do governo local e regional e membros da comunidade devem ser ouvidos em suas críticas e propostas;

- Os empreendedores apresentam suas análises a respeito das críticas e propostas formuladas;

- Os panelistas reúnem as questões formuladas, fazem seus comentários e os apresentam aos técnicos da Agência Ambiental presentes.

A duração de uma audiência pública tem sido da ordem de 4 horas, e de maneira geral, a população tem participado ativamente; não raro, há audiência para cerca de 600 pessoas (APPAH-SAMPONG, 2003).

Os objetivos buscados por essas audiências públicas podem ser assim classificados: 
- Estabelecer um canal de discussão e informar a população do local dos resultados da avaliação ambiental do empreendimento que está sendo proposto;

- Verificar o grau de detalhamento da AIA em relação às realidades locais;

- Certificar que todos os segmentos afetados foram adequadamente consultados e que tiveram a oportunidade de apresentar propostas;

- Promover a participação efetiva e garantir a confiança da população na transparência da tomada de decisão relativa ao empreendimento.

É necessário também que haja uma adequada e livre forma de apresentação de propostas, para que se possam fazer correções confiáveis no projeto, se for o caso, tais como:

- Os impactos ambientais são considerados de grande extensão e além do aceitável;

- Quando há grande oposição da população à execução do citado projeto;

- Quando há grande realocação ou deslocamento de pessoas, famílias ou comunidades.

Há todo um processo de preparação da audiência pública, que obedece, em linhas gerais, aos seguintes tópicos:

- Seleção do lugar para a reunião;

- Divulgação através dos meios de comunicação;

- Convite às lideranças;

- Seleção dos panelistas independentes;

- Inspeção ao local do projeto e sua área de influência. 
Os resultados da audiência são consolidados pelos panelistas independentes, que o apresentam à Agência Ambiental; não raro são elaboradas revisões do projeto com sugestões pertinentes da audiência.

Para que uma audiência pública seja eficaz e apresente resultados significativos, é mister estar atento a alguns aspectos (APPAH-SAMPONG, 2003):

- Representar um canal de comunicação entre os proponentes e os grupos de interesse local;

- Permitir que o público apresente seus pontos de vista sobre o projeto, oferecendo observações e propostas que eventualmente melhorem a qualidade da AIA;

- Promover a aceitação do projeto através de relações harmoniosas entre os proponentes e as comunidades afetadas;

- Estabelecer confiança no processo: este aspecto é medido pela presença da comunidade na audiência;

- Deixar aflorar os conflitos, que possam estar ocultos, para as autoridades locais.

Esses pontos positivos não raro são dificultados por:

- Impossibilidade de entendimento do verdadeiro alcance do projeto pelo nível de educação da população local;

- Incapacidade de se comunicar adequadamente por parte da equipe que elaborou a AIA;

- Omissão ou desinteresse das ONGs em esclarecer a população corretamente, e de fazer comentários pertinentes e isentos sobre o projeto. 


\subsubsection{Tanzânia}

A Tanzânia, como muitos países em desenvolvimento, tem atraído muitos investidores externos. No afã de atrair investimentos, muitas vezes, tem sido sacrificadas políticas que levariam a um desenvolvimento sustentado, trocadas por uma visão de curto prazo.

Nessas ocasiões, torna-se importante $O$ aporte de financiamentos internacionais, que exigem, na maioria das vezes, a elaboração de EIA, especialmente para os empreendimentos de infra-estrutura.

Mas, para que tal aconteça e seja um processo factível, algumas condições precisam ser satisfeitas:

- Vontade política dos governantes;

- Efetiva legislação ambiental;

- Apoio institucional;

- Objetivos adequados de desenvolvimento;

- Pessoal treinado.

Muito provavelmente todas ou quase todas as condições anteriores não são satisfeitas pela maioria dos países em vias de desenvolvimento, em particular a Tanzânia. Este fato leva, muitas vezes, às frustrações por parte dos técnicos da área ambiental, dos conselheiros do governo e do público de uma forma geral (KATIMA, 2003).

Considerações puramente econômicas são determinantes para se implementar projetos inviáveis ambientalmente e que não contam com o apoio popular. Muitas vezes, projetos são levados adiante, mesmo após uma avaliação largamente negativa do ponto de vista ambiental, exclusivamente porque os investidores estrangeiros já fizeram algum aporte de recursos; outras vezes, eles fazem questão de financiar os estudos ambientais, para poder neles influenciar conforme seus pontos de vista e interesses. 
Katima (2003) analisou o caso de um projeto de uma fazenda de camarão na Tanzânia, que teve seu EIA rejeitado pelos técnicos, mas que foi aprovado pelo governo. O autor estabeleceu as seguintes indagações: A quem interessa? Ao investidor? Ao governo? Ao meio ambiente? Ao público?

O projeto se desenvolveu no delta do Rio Rufiji, que representa a maior área de mangue da parte oriental da costa africana. O delta está situado numa extensa área de controle de enchentes, compreendendo $130 \mathrm{~km}$ de extensão, com uma largura média de $20 \mathrm{~km}$, e está ligado ao sistema de correntes marítimas e corais de recifes. Ali vive uma população da ordem de 35.000 habitantes.

Uma empresa africana, subsidiária de uma coreana, pretendia instalar uma fazenda de criação de camarão, com 6.000 ha de superfície de água, e a construção das lagoas ocuparia uma área de 10.000 ha.

O projeto compreendia a construção das lagoas, estações elevatórias, canais de suprimento de água e de drenagem, construções para administração e para armazenamento.

Os processos empregados estimavam que haveria uma produção de 2700 a $4600 \mathrm{~kg}$ camarão/ha, e a utilização de mão-de-obra eram de 250 a 500 empregados na fase de construção, 6.000 na de operação, 500 no berçário e 1200 no processamento.

Do ponto de vista da legislação da Tanzânia, o projeto se contrapunha a uma série enorme de leis, normas e regulamentos, inclusive internacionais e que foram referendados pelo País.

Do ponto de vista ambiental, estimou-se que haveria a perda de 1200 ha de área de mangues; perda da biodiversidade; perdas de áreas de alimentação de pássaros e de berçário de peixes; perdas da fauna, que utiliza a variação das marés; destruição de espécies raras de mangues; ameaça ao crocodilo do Nilo e superexploração de peixes pelo aumento da população. Geraria poluição e eutrofização das lagoas, rios e oceano, que também receberiam efluentes contendo antibióticos e produtos químicos tóxicos. Ocorreria a acidificação e salinização de áreas agrícolas e a 
possibilidade de gerar doenças de veiculação hídrica pelo lançamento de esgoto nos rios próximos.

O inadequado uso do solo sobre os mangues, a extinção de áreas de amortecimento de enchentes, além de não se ter área suficiente para construção de habitações, aterros sanitários e estações de tratamento de águas residuárias eram outros óbices ao projeto.

Do ponto de vista sócio-cultural, haveria perda de áreas de agricultura; expulsão e reassentamento de populações locais em diversas áreas; aumento dos conflitos sociais entre os que eram a favor e os que eram contra o projeto; aumento dos custos governamentais com a construção de infra-estrutura e para serviços sociais e a alteração de valores culturais.

Não se demonstrou a viabilidade econômica do projeto e também haveria a perda de impostos com isenção que seria dada pelo governo e outros incentivos fiscais.

A experiência internacional demonstra que tais projetos se inviabilizam no prazo de cinco anos.

Os procedimentos ambientais para análise e aprovação do projeto foram prejudicados porque não há na Tanzânia, instrumento legal que estabeleça a necessidade de elaboração de EIA. Neste caso, porém, pela pressão popular, o governo exigiu a elaboração de um EIA antes da aprovação do projeto.

Na Tanzânia, há um Conselho Nacional de Gestão Ambiental, que presta assessoria ao governo nas questões ambientais e a Divisão de Meio Ambiente, ligada ao gabinete do Vice-Presidente, que é ouvida em questões ambientais.

O Conselho Nacional de Gestão Ambiental está desenvolvendo os procedimentos para a elaboração de EIAs.

O Centro de Promoção de Investimento tem a responsabilidade de aprovação dos projetos internacionais: sua responsabilidade é analisar a viabilidade econômica. 
O empreendedor desenvolveu um relatório dos impactos ambientais, que serviu de base para a solicitação de empréstimo às agências internacionais para 0 financiamento do projeto.

O relatório foi enviado ao Conselho de Gestão Ambiental para avaliação, e este constituiu um grupo de 11 especialistas, sendo 3 estrangeiros, oriundos dos Estados Unidos, do Zimbábue e da Alemanha.

Os revisores prepararam um relatório e o Conselho Nacional organizou uma audiência pública para a qual acorreram a população interessada local, especialistas de diferentes entidades e políticos.

Trinta e dois participantes fizeram uso da palavra, agregando comentários verbais ao projeto, e 18 escreveram e enviaram aos responsáveis seus comentários, a seguir descritos.

- O projeto foi planejado para se implantar num local inadequado, entre duas importantes áreas na Reserva do mangue, e na marina da ilha Máfia, onde já foram investidos milhões de dólares;

- O plano não prevê tratamento das águas residuárias, que serão despejadas in natura nos rios, que drenam para o canal de Máfia e para os recifes da ilha Bwenjuu;

- As águas residuárias conterão silte e areia, sólidos em suspensão vindos dos alimentos dos camarões e dos sedimentos das lagoas, produtos químicos agregados nos fertilizantes, na alimentação dos camarões e nas vacinas - incluindo antibióticos - e nutrientes;

- Há conflitos entre os planos existentes de uso da terra nas bacias de Rufiji e Ilha Máfia;

- A proposta possuía impactos sócio-econômicos muito negativos, tanto na vizinhança quanto nas regiões menos próximas;

- O EIA não era satisfatório, deixava muitas incertezas na forma e no tamanho do projeto; 
- O EIA, que mostrava muitos atrativos do projeto, era tendencioso.

O Conselho de Gestão Ambiental recomendou ao governo que:

- Fosse rejeitado o projeto e deveria ser elaborado um plano de utilização adequado para a área da Bacia, procurando harmonizar os diferentes tipos e interesses concorrentes de uso;

- Deveria ser estabelecido um prazo para todo uso comercial marítimo da costa da Tanzânia, enquanto o governo estivesse estabelecendo as normas de utilização e as formas de desenvolvimento comercial que deseja para sua aquacultura;

- Grandes projetos de aquacultura não deveriam ser implementados em áreas ecologicamente sensíveis como os mangues;

- A licença concedida deveria ser revogada porque contraria a Política Nacional, o plano de gerenciamento da Ilha Máfia e a legislação sobre os Parques e Reservas.

Após essa dramática experiência, foi constituído um grupo de países do sul da África, denominado Comunidade do Sul da África para o Desenvolvimento, do qual a Tanzânia faz parte.

As primeiras discussões do grupo foram sobre a necessidade de se pautar o desenvolvimento pelo conceito da sustentabilidade ambiental, e logo o grupo tomou a decisão de procurar formas e meios para institucionalizar o EIA e agregou a ele 0 nome de EIA3, significando que os parâmetros fundamentais de análise seriam: equidade, meio ambiente e economia.

Esse grupo procurou institucionalizar os conceitos do EIA, ainda não conseguido na Tanzânia, mas reconheceu que a decisão no projeto das fazendas de camarão, tomada de cima para baixo, deveria ser abandonada.

A despeito de todos os esforços, o projeto foi aprovado pelo governo para implantação, e busca-se agora, com a elaboração do EIA dentro dos novos conceitos, minimizar os impactos que ainda são passíveis de mitigação. 


\subsubsection{Síria}

Em uma breve análise das condições ambientais na Síria, Mahayri (2003) estabeleceu que era necessário a busca de soluções integradas e para que tal meta pudesse ser alcançada, seria necessário buscar os seguintes objetivos:

- Vontade política nos níveis mais altos da administração, apoiando o meio ambiente;

- Melhorar a atual base legal, dando-Ihe mais efetividade;

- Manter comunicações, coordenação e cooperação efetivas;

- Melhorar o fluxo de informações e de gestão; estabelecendo um centro de dados, através do Sistema de Informações Geográficas - GIS;

- Reformar a atual estrutura administrativa;

- Manter contínuos programas de treinamento e de conscientização.

Seria também necessário estabelecer nos planos e programas a transversalidade da questão ambiental, através de Avaliações Ambientais Estratégicas - AAE, para fortalecer os planos ambientais nacionais.

A Síria tem experimentado grandes taxas de crescimento e tem mantido, desde 1995, uma taxa média de $4 \%$ ao ano.

A economia tem gradualmente sido transformada de socialista centralizada para uma de mercado, envolvendo maior participação do setor privado e atividades industriais. No entanto, o meio ambiente não tem sido levado em consideração e tem sido continuamente degradado e contaminado; os recursos hídricos superficiais e subterrâneos estão completamente esgotados e representam um enorme problema; as descargas de efluentes industriais têm causado severa poluição dos recursos hídricos, especialmente os próximos às grandes cidades.

A degradação do solo afeta mais de cinqüenta por cento da produção agrícola; erosão, desertificação e salinização são outros pontos cruciais. 
A urbanização crescente e desordenada tem suprimido áreas de vegetação e muitas delas são convertidas em conjuntos habitacionais ou áreas industriais ou ainda, áreas para deposição de resíduos.

A biodiversidade tem sido fortemente impactada (MAHAYRI, 2003).

Os resíduos sólidos coletados e estimados em cerca de 5000 toneladas por dia, próximo dos valores das grandes cidades, não tem qualquer segregação ou tratamento e causam agudo problema ambiental para as águas superficiais e quando queimados, provocam poluição do ar, que já é contaminado pelas emissões dos veículos e indústrias. A qualidade do ar nas grandes cidades, muitas vezes, está abaixo dos padrões aceitos pela Organização Mundial da Saúde - OMS.

O Ministério do Meio Ambiente conta com duas Agências executivas: A Comissão Central para Negócios do Meio Ambiente (CCNMA), que é uma agência técnica, e o Centro de Pesquisa Científica e Ambiental (CPCA), seu braço de pesquisa.

A análise dos EIAs é de responsabilidade da CCNMA, que possui uma unidade específica para este fim, denominada UEIA.

A legislação não fornece instrumentos efetivos para a atuação tanto do braço técnico como da unidade UEIA.

Não raro outros ministérios influenciam nas atividades da CCNMA, interferindo em sua autoridade e a apontam como a responsável pelo atraso do crescimento econômico.

Há pouca e não confiável informação sobre o número de ElAs submetidos às autoridades.

No caso geral, os empreendedores do setor privado, cujos projetos são de pequeno porte, são informados por outro Ministério - que é a autoridade licenciadora, que devem procurar a área ambiental para validar sua licença. 
O empreendedor então se apresenta à unidade UEIA. Após discussões sobre o projeto, algumas orientações e recomendações são agregadas à licença. Algumas vezes, uma inspeção ao local do projeto é feita.

Mais de $50 \%$ dos projetos que são submetidos para a Unidade UEIA são de empreendimentos que já se encontram em operação, e a grande maioria com significativos impactos ambientais.

Nestes casos, são poucas as ações cabíveis: ou se propõe a mitigação dos impactos mais significativos se for possível, ou fecha-se a fonte poluidora, que é relocada para outra área.

Em qualquer dos dois casos, a decisão final não é tomada pela Unidade UEIA, mas pelas autoridades políticas, que não são obrigadas a seguir as recomendações da Unidade.

O licenciamento ambiental representa um ponto fraco na legislação existente e é fonte de conflitos de competência entre diferentes órgãos da administração.

Está em tramitação a lei da política ambiental, a chamada EPAct (Environmental Protection Act), que dará poder legal para a Unidade UEIA. Esse diploma legal estabelece que a UEIA é a "autoridade de permissão ou licenciadora".

A expressão "autoridade licenciadora" é usada na EPA, enquanto que no Decreto regulamentador, também em tramitação, a expressão utilizada é "autoridade de permissão".

Esta deliberada confusão leva a Unidade UEIA a encaminhar, normalmente, a decisão final para a autoridade política (MAHAYRI, 2003).

Há, pois, um processo de enfraquecimento da autoridade ambiental, provocado por essa ambigüidade, fato que propicia o aparecimento de problemas burocráticos, estabelecendo mais procedimentos que devem ser cumpridos até que a decisão final seja tomada. 
Para os empreendimentos, existem duas autorizações a serem expedidas: a setorial e a administrativa.

A construção pode ser iniciada após o recebimento da LICENÇA SETORIAL e a operação, só após a liberação da LICENÇA ADMINISTRATIVA, que envolve o EIA. Normalmente, o empreendedor inicia a construção e muito provavelmente a conclui, antes de saber se o EIA será ou não aprovado. Esse fato leva a situação que, mesmo que o funcionamento não seja aprovado, o impacto da fase da construção já ocorreu e normalmente é irreversível. Mais ainda, supondo que o empreendedor saiba que irá precisar elaborar um EIA no estágio inicial, ele pode começar a construção com a outra licença, esperando encontrar as soluções oriundas de problemas identificados no EIA, mais tarde. Dessa forma, o projeto atinge um estágio em que os recursos nele investidos tornam irreversível sua implantação, mesmo com os problemas ambientais apontados.

A legislação estabelece os procedimentos para a elaboração do EIA, seu escopo e abrangência, e ainda, que a Unidade UEIA deve analisá-lo em dois anos. Só que todo o contingente de pessoal da Unidade é de cinco pessoas.

Também estabelece que os Termos de Referência para os EIAs devem obedecer a padrões previamente definidos, no entanto, a mesma legislação define que o resultado do EIA será a base da Avaliação Ambiental Estratégica, o que é uma incoerência.

Há uma grande carência de pessoal técnico e os consultores da iniciativa privada não estão disponíveis na Síria.

A elaboração dos EIAs por parte dos empreendedores coloca grande pressão ao corpo técnico da administração; é de se esperar que a continuar as condições atuais, os eventuais avanços propiciados pela elaboração dos EIAs se tornem absolutamente ineficazes.

Outro problema diz respeito a pouca capacitação técnica do corpo funcional, o que traz como conseqüência a inexistência de massa crítica sobre as questões ambientais e encoraja os não habilitados a estabelecer um número grande de 
condições para elaboração de EIA, acrescentando desnecessários procedimentos burocráticos.

Levando em conta a fase de transição que o país atravessa; o maior incremento das atividades econômicas e o estágio de degradação dos ativos ambientais, pode-se concluir que mesmo com as fragilidades apontadas, os EIAs e as AAE, quando aplicados corretamente, são instrumentos importantes na busca da sustentabilidade e que as principais ações devem ser:

- Fortalecer a legislação ambiental;

- Aprimorar os procedimentos administrativos;

- Melhorar a comunicação, a coordenação e a cooperação entre os atores;

- Maior conscientização sobre as questões ambientais;

- Experiência, recursos e informação.

Os seguintes pontos podem e devem ser incentivados, especialmente se houver vontade política (MAHAYRI, 2003):

- Coordenação e cooperação nacionais;

- Promoção do setor privado;

- Melhor gerenciamento da informação;

- Centro nacional de geoprocessamento;

- Programas de conscientização e treinamento.

\subsubsection{Continente Asiático}

\subsubsection{Malásia}

A legislação ambiental da Malásia estabelece que as decisões ambientais devam ser centralizadas no governo federal. 
Mais recentemente, os estados Sarawak e Sabah adotaram procedimentos independentes para avaliação dos impactos ambientais nos recursos naturais e é provável, que em futuro próximo, outros estados procedam da mesma forma.

A centralização federal na Malásia ocorre desde a primeira lei de Qualidade Ambiental, promulgada em 1974, a Environmental Quality Act (EQA).

O principal objetivo dessa lei é a redução da poluição, seu controle e mitigação, procurando comparar a magnitude do problema e levando em conta as manifestas preocupações da população.

Numa primeira fase, que vai de 1970 até 1980, os principais problemas de poluição estavam centrados nas indústrias de fabricação de óleo de palma e borracha (MEMON, 2003).

Em 1987, foi introduzido o conceito de avaliação dos impactos ambientais, com ênfase na prevenção à poluição. Contribuiu para essa mudança conceitual, o aumento da industrialização e a rápida urbanização que o país experimentou nos anos 1990 , onde o produto interno bruto cresceu na faixa de sete por cento ao ano.

Os procedimentos estabelecidos na Malásia foram semelhantes ao modelo praticado nos Estados Unidos.

A legislação EQA define que 19 categorias de atividades têm que requerer AIA para sua implantação no país.

Entre 1988 e 1993, foram submetidos à análise, os seguintes AIAs: (Tabela 3.3) 
Tabela 3.3 - Número de AIAs submetidos à análise na Malásia de 1988 a 1993

\begin{tabular}{|c|c|}
\hline Atividade & Número \\
\hline Hotéis & 129 \\
\hline Infraestrutura & 125 \\
\hline Mineração-pedreiras & 100 \\
\hline Indústria & 99 \\
\hline Habitação & 98 \\
\hline Petróleo & 59 \\
\hline Tratamento de Resíduos & 57 \\
\hline Geração de Energia & 30 \\
\hline Recuperação de áreas degradadas & 17 \\
\hline Silvicultura & 16 \\
\hline Drenagem & 14 \\
\hline Mineração - metais & 14 \\
\hline Agricultura & 10 \\
\hline Abastecimento de água & 9 \\
\hline Zonas exclusivas de exportação & 8 \\
\hline Portos & 7 \\
\hline Pesca & 2 \\
\hline Ferrovias & 1 \\
\hline Rodovias & 1 \\
\hline Aeroportos & 1 \\
\hline TOTAL & 784 \\
\hline
\end{tabular}

AIA - Avaliação de impacto ambiental

Fonte: Adaptado de Memon (2003)

Diante do grande número de submissão de AlAs, houve a necessidade de descentralizar as ações, e para tanto, foram criados escritórios regionais, especializados conforme a vocação local predominante. 
A maior dificuldade no processo de descentralização foi devida às condições da Lei Constitucional do país e por causa das implicações políticas. O governo federal teve de tratar cautelosamente o processo, procurando não transparecer aos Estados, que estava havendo indevida invasão de atribuições.

Foram sendo identificados diversos problemas, todos comparáveis aos que ocorriam em países com o mesmo grau de desenvolvimento, tais como:

- Falta de percepção da AIA como instrumento de planejamento: alguns interpretavam a AIA como obstáculo ao desenvolvimento;

- Críticas de que a elaboração da AIA representaria atraso na aprovação, execução e implementação dos projetos;

- A AIA era elaborada tardiamente, acarretando problemas, tais como localização e falta de consideração de tecnologias mais apropriadas;

- Ausência de padrões para análise de qualidade ambiental;

- Fraca previsão dos impactos;

- Participação pública limitada.

Através de emenda constitucional, estabeleceu-se um conjunto de atividades cujas AIAs seriam de avaliação exclusiva do governo federal - Lista I, e dos governos estaduais - Lista II, e de ambos - Lista III.

Alguns estados começaram, então, a elaborar regras próprias para os diferentes empreendimentos, gerando algumas controvérsias, que precisaram ser dirimidas na Suprema Corte de Justiça. Tal foi o caso da aprovação da construção de uma usina hidrelétrica, onde o Estado questionou os procedimentos adotados pelo governo federal, alegando que haviam sido facilitados os procedimentos de aprovação do projeto que estava no "coração dos vestígios remanescentes da floresta tropical" (MEMON, 2003).

A Corte Suprema rejeitou os argumentos do Estado, alegando que eles refletiam somente a inépcia da burocracia. 
O Gabinete do Governo Federal anunciou a aprovação do projeto, que se mostrou um dos mais importantes para o desenvolvimento do sudeste asiático.

O projeto compreendia a formação de um reservatório, a construção da barragem, a geração e as linhas de transmissão de energia, e uma linha de transmissão submarina sob o mar do sul da China, para levar energia às Filipinas.

Houve também uma ampla divulgação pública do projeto ensejando participação popular e o público foi convidado a oferecer comentários e sugestões.

Foi preparada uma versão a AIA, em linguagem de fácil acesso e ao final, todas as propostas foram submetidas a um Painel de Especialistas Independentes, que juntamente com diversos grupos de interesse, avaliaram os custos e benefícios do projeto à comunidade.

Algumas fases do projeto ainda estão em implementação, especialmente por causa da recente crise econômica e, olhando retrospectivamente, é de se reconhecer que as incertezas econômicas são até mais efetivas para determinar os destinos de grandes projetos do que os regulamentos ambientais.

Pode-se avaliar como os processos administrativos oferecem dificuldades para a definição dos compromissos ambientais e os arranjos institucionais dos regulamentos ambientais nos países dependem da distribuição do poder e das funções entre os diferentes atores do governo (MEMON, 2003).

Na grande maioria dos países, os regulamentos ambientais são compartilhados com os estados e esse fato pode dar origem à fragmentação, à sobreposição de funções, que diminuem a efetividade da legislação ambiental.

Segundo Memom (2003), meio ambiente é um conceito holístico, onde o que se busca alcançar é uma grande integração das decisões, levando em consideração a grande interdependência ambiental.

Assim, pode-se afirmar que existem argumentos a favor e contra a descentralização das decisões ambientais; países como a Nova Zelândia, que empreendeu um 
agressivo processo de descentralização, verificaram que muitos problemas foram subestimados no processo.

Há grande preocupação na Malásia quanto à capacidade das autoridades locais ou regionais de efetivamente implementarem os regulamentos ambientais, que muitas vezes demandam um compromisso político e uma capacidade de gestão para uniformizar as práticas ambientais em nível nacional.

\subsubsection{2 Índia}

O projeto da hidrelétrica de Bodhghat envolve a construção da maior barragem no Rio Indravati no Distrito de Bastar, e representa o primeiro de uma série de outras seis barragens para aproveitamento hidrelétrico das suas águas.

Está situado a $100 \mathrm{~km}$ da cidade de Jagdalpur, e compreende uma barragem de concreto por gravidade com 1720 m de comprimento, com 90 m de altura, um túnel com $3 \mathrm{~km}$ de extensão, um canal de fuga com $5 \mathrm{~km}$, e com casa de força para 4 turbinas de $125 \mathrm{MW}$ cada, no total de $500 \mathrm{MW}$, para prover energia de ponta.

A área de inundação é de 14 milhões de hectares, dos quais 5,8 milhões são de uma reserva protegida. O projeto ainda prevê o deslocamento de 10.000 habitantes de 42 vilas.

Quando o projeto foi iniciado, ainda não havia na Índia legislação efetiva para a elaboração do EIA. Nessa época, a viabilidade do projeto era avaliada através da formalização de uma votação local, que normalmente era conduzida pelo Departamento de Meio Ambiente (RAJVANSHI, 2003).

O empreendimento estava inicialmente avaliado em US\$ 50 Milhões, deveria levar 6 anos para sua implementação completa e o governo da Índia buscou financiamento externo no Banco Mundial.

O projeto foi revisado e após uma missão de avaliação do Banco, o valor do investimento subiu para US\$ 304 Milhões. 
O Instituto de Floresta da Índia apresentava diversas objeções ao projeto do ponto de vista ambiental e o governo decidiu submetê-lo a uma avaliação por parte de uma agência independente, que deveria estar focada especialmente nos impactos sobre a flora e a fauna, que representavam os aspectos mais críticos.

Em paralelo, duas condições se desenvolviam: o aperfeiçoamento dos instrumentos legais e a controvérsia instalada sobre o "Silent Valley".

A população local também começou a manifestar oposição ao projeto, pois não vislumbrava as medidas compensatórias prometidas; as ONGs, os lobbies ambientalistas e diversos movimentos sociais enviaram correspondências ao Primeiro Ministro da Índia, o que forçou o Governo a levar em conta as diversas manifestações recebidas contra o projeto.

Foi formado, então, um Comitê especial, sob a direção do Ministro para o Meio Ambiente e Florestas, para reavaliar as questões ambientais e sociais.

Ao mesmo tempo, o Governo, através do Departamento de Floresta, contratou o Instituto para a Vida Silvestre da Índia - Wildlife Indian Institute - (WII), para elaborar o EIA num prazo de seis meses.

Após intenso trabalho, o WII concluiu que os impactos ecológicos e sociais de longe ultrapassavam os eventuais benefícios econômicos.

A conseqüência foi a rejeição do projeto, mesmo após uma substancial parte das atividades de construção terem sido implementadas, pois se iniciaram antecipadamente às análises do projeto, com a conivência das autoridades. Algumas delas foram concluídas, como conjuntos habitacionais, centros de saúde e educação, centro administrativo, pontes, partes do canal e do túnel, as escavações para as fundações da barragem e da casa de força.

Ficaram algumas lições importantes deste projeto:

- Os paradigmas econômicos e técnicos não podem ser analisados isoladamente quando se pensa em desenvolvimento sustentado; 
- A elaboração do EIA mostra que se deve dar grande atenção aos efeitos cumulativos e sinérgicos dos impactos nos ecossistemas;

- Um projeto dessa envergadura funcionará como paradigma para outros na mesma área;

- O reassentamento de populações tem importante significado no projeto;

- Os princípios de sustentabilidade ambiental devem ser incluídos na metodologia e nos padrões que conduzem ao EIA, e deve ser dada adequada importância à conservação da biodiversidade e aos impactos da sua perda;

- EIA de boa qualidade necessita de cuidadosos padrões de análise da dimensão sócio-econômica;

- O projeto terá pouca possibilidade de sucesso se ignorar ou subestimar as tradições, os valores e as organizações sociais das comunidades afetadas, especialmente se seu objetivo for separá-las integralmente dos seus ritos diários;

- A pressão pública pode, com freqüência, ajudar a conservação ambiental, especialmente se houver vontade política.

O projeto teve sua execução rejeitada.

\subsubsection{Continente Europeu}

A União Européia define a Licença Ambiental como "parte ou a totalidade de uma ou mais decisões escritas que concedem o direito de explorar toda ou parte de uma instalação em determinadas condições que permitam garantir que a instalação preencha os requisitos da Diretiva 2008/1/CE. Uma licença pode ser válida para uma ou mais instalações ou partes de uma instalação, situadas no mesmo local e exploradas pelo mesmo empreendedor" (Diretiva 2008/1/CE - Art.2ํㅡ - 9). 
Esta Diretiva procurou estabelecer uma abordagem integrada de combate à poluição em âmbito comunitário, especialmente no que diz respeito à poluição industrial.

Desde 1984, havia a exigência de licenciamento prévio de exploração de instalações industriais, ou a introdução de qualquer modificação nos processos industriais das mesmas, que pudessem causar poluição atmosférica.

Os seguintes princípios regem a Diretiva:

- Há a necessidade de se ampliar o espectro da prevenção e controle da poluição de forma integrada, sempre que viável, das emissões para o ar, para a água, para o solo, gestão de resíduos e, sempre que possível, incentivar a minimização de tais emissões (Exposição de motivos - item 9 - Diretiva 2008/1/CE)

- Estabelece ainda - item 20 - que aos estados-membros fica facultado, sempre que as condições exigirem, a formulação de condições mais rígidas, desde que factíveis e previstas no licenciamento como condições suplementares.

- As condições de participação popular estão enunciadas no item 24 da Diretiva e deverão permitir a expressão da comunidade. O agente público deverá levar em consideração as contribuições relevantes, “aumentando assim a responsabilização e transparência no processo de tomada de decisões e contribuindo para a sensibilização do público às questões ambientais e o apoio às decisões tomadas".

Para tanto, a Comunidade Européia assinou em 1998, a Convenção de Aarhus, que estabelece como objetivos garantir ao público os direitos de ampla informação e de participação na tomada de decisões em questões ambientais, a fim de contribuir para a proteção do direito dos indivíduos de viverem num ambiente propício à sua saúde e bem estar.

- Outro ponto importante no que diz respeito ao licenciamento ambiental das instalações é a ênfase na utilização das melhores técnicas disponíveis, que representam a “... fase de desenvolvimento mais 
eficaz e avançada das atividades e dos respectivos modos de exploração, que demonstre a aptidão prática de técnicas específicas para constituir em princípio a base dos valores-limite de emissão com vista a evitar e, quando tal não seja possível, a reduzir, de um modo geral, as emissões e o impacto no ambiente, no seu todo" - (Item 12).

- Enfatiza a necessidade do cumprimento das condições de licenciamento, informando que os empreendedores devem atender ao estabelecido nas licenças; comunicar regularmente às autoridades sobre o monitoramento e prestar aos representantes da autoridade ambiental toda a assistência necessária à realização da sua função, em especial quanto às coletas de amostras e todas as demais informações solicitadas (Art. 14$)$.

- Propõe que se deve assegurar amplo acesso à justiça aos que tem possibilidade de interpor recurso (Art.16º); incentiva o intercâmbio de informações entre os Estados Membros (Art. 17º) e alerta para 0 problema da transposição da poluição através das fronteiras entre os

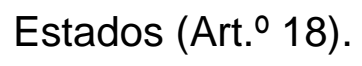

- No anexo 1, são definidas as atividades industriais que estão submetidas a esse diploma legal e que estão classificadas conforme os seguintes setores: energia, produção e transformação de metais, mineração, química, gestão de resíduos, e outras atividades como papel, têxteis, curtimento de peles, matadouros, laticínios, criação de aves, tratamento com solventes.

Chama a atenção que o setor de saneamento em nenhum momento é classificado como passível de licenciamento, atendendo aos mesmos parâmetros das indústrias, embora os padrões de lançamento de efluentes sejam rigorosamente estabelecidos, não se discute o problema das obras lineares de transporte de águas, elevatórias e mesmo estações de tratamento. 


\subsubsection{Finlândia}

As avaliações ambientais são definidas como instrumento-chave na política ambiental da Finlândia. Polonem (2006) analisou aspectos da sua aplicação na Europa e em particular na Finlândia, afirmando que erros podem ser freqüentemente cometidos em certos procedimentos para os licenciamentos e que as análises ambientais são tão limitadas que somente a parte menos significativa do EIA (Environmental Impacts Assessment) é levada em conta.

A atual legislação ambiental da Finlândia e da União Européia não garante que os filtros colocados no estudo sejam seguidos na decisão política de executar o empreendimento.

Esse pesquisador, explicitando melhor a sua crítica, assim se expressa: "a despeito da sua contribuição, a legislação e a prática finlandesa da AIA contém alguns pontos falhos que enfraquecem o seu propósito como instrumento preventivo. Os problemas podem também ser debitados parcialmente ao reflexo de se seguir uma legislação mais ampla e geral para toda a comunidade européia."

Comparando com outros países, o autor destaca a Alemanha, onde a avaliação deve conter "uma visão da mais importante entre as soluções consideradas como opções aventadas pelo empreendedor e o estudo deve conter as razões essenciais para a escolha final do projeto".

$\mathrm{Na}$ Inglaterra, a legislação prevê uma "visão completa das principais alternativas estudadas pelo empreendedor ou pretendente, e as principais razões da escolha da alternativa eleita, levando em conta seus efeitos ambientais".

Na Finlândia, a legislação prevê uma obrigação estrita para que os empreendedores examinem as alternativas razoáveis, mas na prática nem sempre isto é feito.

As autoridades competentes não têm sido suficientemente rigorosas nesse aspecto, levando os empreendedores a ignorar as reais alternativas. Tal procedimento implica, não raro, na judicialização dos licenciamentos ambientais. 
O controle de qualidade ambiental das condições impostas na AIA é exercido com base numa lei nacional, que delega a responsabilidade para os Centros Regionais Ambientais.

Problemas ocorrem quando as autoridades que coordenaram os estudos, por alguma razão, falham na análise da qualidade dos Estudos Ambientais e sua adequação à legislação.

Há casos de ocorrência de erros bastante graves, que acabam sendo analisados pela Corte Suprema, como por exemplo, um que diz respeito ao licenciamento de um aterro sanitário.

A Corte Suprema indicou claramente que houve falhas na análise dos estudos, mas mesmo assim não revogou o licenciamento concedido. $E$ a razão alegada foi que o empreendedor forneceu informações suplementares suficientemente convincentes após os procedimentos da AIA.

Este fato implicou na mudança da Diretiva da AIA, que passou a requerer "que o público tenha acesso aos procedimentos de revisão antes que a Corte ou outro organismo independente e imparcial tenha analisado e oferecido sugestões para evitar ilegalidades e/ou omissões."

Para se ter uma idéia dos conflitos, Polonem (2006) relata que entre 1996 e 2005, mais de 30 casos, que envolveram conflitos, foram decididos na Corte de Justiça. $\mathrm{Na}$ Inglaterra, os casos que aportam ao Judiciário são ainda mais numerosos.

Há situações também em que as razões políticas passam a ter influência até deletéria ao meio ambiente.

Os estudos ambientais custam aos empreendedores vultosos recursos em análises e pesquisas e de uma maneira geral, as autoridades políticas não são muito sensíveis a esses argumentos; assim, há uma frágil ligação entre os estudos e as decisões políticas.

Do ponto de vista legal, há o consenso que o problema está conectado com os procedimentos e a natureza da legislação que rege a AIA. 
De acordo com a legislação da AIA, o Administrador não precisa estar alinhado com a obrigação de evitar os efeitos negativos no meio ambiente. Assim, "a submissão do projeto a AIA é simplesmente uma garantia formal e não necessariamente impõe um esforço concreto de controle ecológico" (POLONEM, 2006).

Mas, de uma maneira geral, no sistema da Finlândia, as normas de licenciamento garantem que, na maioria dos casos, as informações essenciais reunidas nas avaliações dos impactos sejam efetivamente levadas em conta antes das atividades serem iniciadas.

E ao final do artigo, Polonem (2006) estabelece as seguintes conclusões:

- A qualidade do EIA é um dos fatores-chave, que constitui um efetivo parâmetro para a Avaliação dos Impactos Ambientais - AIA;

- Na comunidade européia, a qualidade dos documentos das avaliações é essencialmente dependente das legislações e das práticas nacionais;

- Um aspecto importante foi agregar maior participação pública às decisões. As emendas nas diretivas introduzidas em 1997 e 2003 foram nessa direção;

- Outra obrigação que tem sido introduzida é um amplo estudo de alternativas; elas devem conter um mínimo de informações fornecidas pelos empreendedores e devem indicar com clareza um exame acurado das mesmas;

- Uma falha do sistema finlandês e que se refere à revisão final das AIAs é o fato de que certos procedimentos de licenças ambientais levam em conta somente os impactos de menor importância;

- Há fortes pressões para que tais procedimentos sejam revistos. 


\subsubsection{Irlanda}

A Irlanda passou por um processo importante de transição política, que apresentou reflexos na atual política ambiental.

Pode ser interpretado, também, que essa transição representa uma forma de aprendizado político que tem recebido pouca atenção das autoridades e diz respeito a estabelecer uma política institucional de preservação do patrimônio cultural e ambiental.

No caso particular da Irlanda, há que ser analisada também as influências regulatórias decorrentes da estreita ligação com a Inglaterra.

A necessidade urgente de uma regulação para acompanhar o desenvolvimento da Irlanda sugeriu a criação de uma Agência de Proteção Ambiental - EPA, e que se estabelecesse uma ligação estreita entre o que ocorreu no país com o forte desenvolvimento da Inglaterra nos anos 1990.

Taylor (2001) lembra que durante a elaboração da legislação irlandesa, os cidadãos expressavam o sentimento que a Inglaterra era um país com "menor consciência ambiental" e muito orientada para o desenvolvimento industrial. Nesse aspecto, a Irlanda não queria seguir a filosofia inglesa.

Esse fato não significa que não se teve transferência de políticas ou que as regras da EPA Irlandesa não foram influenciadas pelas políticas inglesas.

Estas influências podem ser notadas nas leis locais de Planejamento e Desenvolvimento (1963), na Lei de Poluição das Águas (1977), por exemplo, que representam extensões das leis Britânicas dos anos 1950.

As novas leis irlandesas mostram mais o caminho da continuidade do que perfilam o das mudanças. Pode-se afirmar, pois, que há uma "memória institucional" (TAYLOR, 2001).

Na sua forte ou fraca variação, o discurso da modernização ecológica abraça temas que são presumidamente novos, mas distintos. 
A crítica recebida é que a política não deveria ser a do fato consumado "faz e depois conserta", mais a de "antecipar para prevenir" e que deveria haver um procedimento integrado para diminuir a poluição, a utilização do princípio do poluidor-pagador e as diversas formas de análise de riscos (TAYLOR, 2001).

Muitos dos princípios utilizados hoje foram transferidos da Inglaterra. Não houve a propalada ruptura em relação aos procedimentos ingleses, especialmente nas práticas regulatórias, o que evitou a "reinvenção da roda".

$\mathrm{Na}$ Irlanda, as questões ambientais têm sido tratadas através de uma estrutura dispersa de agências públicas, com pouca ou nenhuma abordagem integrada.

A política tem sido reativa e fragmentada, utilizando um sistema arcaico de comando-controle ao invés de estabelecer princípios de prevenção ou de regulação, que representam a abordagem mais moderna.

Em meio às turbulências eco-políticas dos anos 1980, não se pode negar que esse período deixou claro excelentes oportunidades e razões para se estabelecer regulações na área ambiental, o que possibilitou um aprendizado de como se alterar as condições das políticas ambientais na Irlanda.

Foi nesse contexto que a Irlanda criou a Agência Ambiental e introduziu o conceito de controle da poluição integrado (Integrated Pollution Control - IPC).

Este conceito, disseminado fortemente na União Européia, ali foi introduzido pelo ato nº1990, que objetiva controlar as emissões dos processos industriais, especialmente no que diz respeito ao ar, solo e água. Incentiva a utilização da melhor tecnologia disponível, desde que não coloque custos excessivos aos empreendedores.

Esse princípio seria gradualmente ajustado para o mais restritivo e adequado princípio Integrado de Prevenção e Controle da Poluição, dentro das diretivas da Comunidade Européia.

Em 1963, o Parlamento Irlandês aprovou um plano de controle ambiental, similar ao da Inglaterra. 


\subsubsection{Escócia}

A Agência de Proteção Ambiental Escocesa (Scotland Environmental Protection Agency - SEPA) é a responsável pela implementação da legislação ambiental na Escócia, que em linhas gerais, segue a legislação inglesa, que por sua vez, está vinculada à Diretiva Européia.

É dado enfoque especial à sustentabilidade e ao desenvolvimento e define algumas atividades nas quais há a necessidade de aprofundamento dos estudos ambientais e para essas são exigidas licenças ambientais:

- Produção energética envolvendo combustão e refino;

- Produção e processamento de metais;

- Atividades minerais, tais como a produção de cimento, calcário, vidros e cerâmicas;

- Produtos químicos, incluindo fertilizantes e fármacos;

- Manejo de resíduos, tais como operação de incineradores e/ou aterros;

- Atividades envolvendo usos de solventes para revestimentos, tintas e limpeza;

- Operação de plantas móveis de resíduos;

- Usos de água;

- Transporte de efluentes e de resíduos;

- Resíduos especiais;

- Substâncias radioativas.

Na Escócia, há três níveis de autorizações que devem ser obtidas na SEPA. Estas se aplicam especialmente ao lançamento de águas residuárias em corpos hídricos.

O tipo de autorização vai depender do porte do empreendimento; das exigências que o empreendedor deve cumprir e da magnitude dos impactos ambientais. 
O agente que autoriza deve estar seguro que não haverá qualquer tipo de contaminação nas águas superficiais ou subterrâneas, tais como vazamentos de óleos de veículos, ou mesmo contaminação da água de chuva por emissões gasosas. Se errar, o agente estará sujeito às sanções criminais.

O instrumento central utilizado pela Agência para controlar os impactos ambientais é o sistema integrado de prevenção e controle da poluição (Integrated Pollution Prevention and Control - IPPC), utilizado para as atividades industriais anteriormente referidas.

Os empreendedores devem assumir o compromisso de sistematicamente buscar utilizar em seus processos as melhores técnicas disponíveis (Best Available Techniques - BAT); esse compromisso, porém, ressalva que, sendo o ponto central a proteção do meio ambiente de forma atualizada e permanente, deve ser utilizada uma tecnologia que propicie o balanço entre os benefícios e os custos.

A implementação do IPPC objetiva:

- Proteger o meio ambiente como um todo;

- Promover o uso de tecnologias mais limpas para minimizar a emissão de resíduos;

- Incentivar a inovação tecnológica;

- Estabelecer balanço entre os benefícios e custos.

\subsubsection{Espanha}

A legislação espanhola para o meio ambiente está baseada no Decreto Legislativo Real no 1302, de 28 de junho de 1986.

Esse decreto vale tanto para o setor público como para o privado e entrou em vigor quando a Espanha aderiu à Comunidade Européia. Define uma lista de atividades que devem nortear o estudo de avaliação dos impactos ambientais: projetos 
detalhados, grande potencial poluidor que possam causar significativo impacto ambiental (ESPINOZA, 2002).

Situação peculiar é relativa aos projetos de defesa do território, excluídos da exigência de apresentação de EIA e aprovados como tal, por lei específica.

Um projeto pode ser excluído das exigências ambientais por decisão das autoridades. Nesses casos, o governo deve expor as razões de exceção para a Comissão Ambiental da Comunidade Européia, mantendo as razões dessa excepcionalidade disponíveis para consulta pública.

A legislação espanhola especifica que o projeto, incluindo o estudo de impacto ambiental, deve:

- Descrever claramente o projeto, suas diferentes atividades na produção e prováveis futuros aperfeiçoamentos;

- Examinar as alternativas viáveis e justificar a solução adotada;

- Fornecer na futura operação, em forma de inventário, a descrição das interações ambientais e ecológicas dentro dos parâmetros ambientais;

- Identificar e avaliar os impactos ambientais ou alternativas;

- Propor medidas de redução, eliminação ou compensação dos efeitos ambientais adversos e possíveis alternativas;

- Submeter um consistente programa que garanta o compromisso com as diferentes medidas mitigadoras propostas no estudo;

- Apresentar sumário conclusivo sobre a viabilidade, as diferentes alternativas, a proposta de medidas corretivas e um programa de ações mitigadoras.

Os estudos devem estar devidamente interligados aos efeitos indiretos que podem ser causados às populações, à fauna, à flora, ao solo, ao ar, à água, ao clima e incluir ainda o patrimônio histórico, artístico e arqueológico. 
As autoridades devem facilitar a elaboração dos estudos, fornecendo todas as informações disponíveis ao proponente do projeto. Para tanto, o empreendedor deve seguir os procedimentos:

- Primeiro deve enviar comunicação ao Escritório Geral de Administração para o Meio Ambiente - Ministério de Obras Públicas e Urbanismo - e manifestar a intenção da execução do projeto, anexando um sumário e suas características principais;

- A administração consulta a população e as instituições, que presumivelmente serão afetadas; acrescenta seus comentários e informa as possíveis influências ambientais que poderão advir. Estes comentários são feitos por técnicos da administração, especializados em meio ambiente:

- A administração informa ao autor do projeto, o resultado das consultas e os comentários mais significativos, que devem ser considerados na implementação dos estudos posteriores;

- O empreendedor prepara e submete à administração o EIA, que é levado à consulta pública e com as sugestões apresentadas, pode ser revisado;

- Finalmente, o EIA é concluído, incorporando as sugestões e dando as condições para a sua implementação, incluindo os mecanismos de acompanhamento e monitoramento. Este estudo é encaminhado à Administração, que emite a resolução administrativa autorizando o projeto. 


\subsubsection{Portugal}

A aplicação da Diretiva 2008/1/CE aos Estados Membros da Comunidade Européia evidencia o compromisso e a estrita observância dos princípios nela definidos e com as condições e atualizações particulares do seu contexto.

A transposição dos comandos da Diretiva para as instituições de Portugal foi feita pelo Decreto Lei 173/2008 de 26 de Agosto de 2008.

$\mathrm{Na}$ exposição de motivos dessa lei, destaca-se: "... a necessidade de proceder a sua atualização, de forma a adequar e tornar mais célere o procedimento de licença ambiental nele prevista, harmonizando-o com outros regimes jurídicos que preveem igualmente, procedimentos de licenciamento ou de autorização de instalações, designadamente o regime de exercício da atividade industrial (REAl), num esforço de simplificação legislativa e administrativa com vista à obtenção de ganhos de eficiência."

Prossegue o texto: "A alteração mais significativa consubstancia-se no fato da licença ambiental passar a constituir uma condição de início de exploração ou funcionamento da instalação e não, como até agora, uma condição da execução do projeto de instalação. Prevê também a possibilidade do empreendedor recorrer a entidades acreditadas na preparação do pedido de licença ambiental, que o validando, cria condições que permitem a redução do prazo fixado para a decisão."

O Art. $2^{\circ}$ estabelece algumas definições e destacam-se:

- Documentos de referência sobre as Melhores Técnicas Disponíveis (MTDs): documentos produzidos por um painel europeu de especialistas, com o objetivo de definir as melhores técnicas disponíveis para diversos setores industriais, também denominados documentos BREFs (Best Available Technologies - BAT References), que estão disponibilizados no site da Agência Portuguesa do Ambiente (APA);

- Entidade Acreditada: entidade reconhecida formalmente pelo Organismo Nacional de Acreditação, no domínio do Sistema Português 
de Qualidade, com competência para realizar atividades específicas no âmbito do pedido de licença ambiental.

- Entidade Coordenadora (EC): entidade a quem compete, nos termos da legislação aplicável, a coordenação do processo de licenciamento ou autorização das atividades referidas no anexo I, e a emissão da autorização ou da licença para a instalação, alteração e exploração das atividades industriais ali constantes. $O$ anexo I se refere aos setores de maior potencial poluidor, tais como: energia, transformação de metais, indústria mineral, química e gestão de resíduos.

- Licença ambiental: decisão escrita, que visa garantir a prevenção e o controle integrados da poluição, proveniente das instalações abrangidas pelo decreto-lei no 173/08, estabelecendo as medidas destinadas a evitar, ou se tal não for possível, a reduzir as emissões para o ar, a água e o solo, a produção de resíduos e a poluição sonora, constituindo condição necessária da exploração dessas instalações;

- Licença de exploração: titulo emitido pela EC que habilita a exploração das instalações.

Interessante destaque aparece no Artigo 3ำ - 2 "excluem-se do âmbito do presente decreto-lei, as instalações ou parte de instalações utilizadas exclusivamente para investigação, desenvolvimento, ou experimentação de novos produtos ou processos".

Em seu Art. 7ํㅡㄹ destacam-se as condições que devem satisfazer a aplicação das MTDs, cujos critérios estão anexados ao Decreto, e elas devem "levar em conta os custos e benefícios que podem resultar de uma ação e os princípios da precaução e da prevenção".

O Art. $8^{\circ}$ trata da composição da Comissão Consultiva para a Prevenção e Controle Integrado da Poluição (CCPCIP). Sua função é acompanhar a aplicação do DecretoLei e ela irá funcionar junto à Agência Portuguesa do Ambiente (APA). 
A CCPCIP é constituída por membros nomeados pelo governo e pertencentes às seguintes áreas: ambiente, agricultura, economia, saúde e também por representantes dos setores industriais.

A competência do CCPCIP é, conforme o Art. $8^{\circ}$ - 2:

- Análisar as MTDs por setor de atividade;

- Análisar os documentos de suporte e de informação sobre as MTDs;

- Acompanhar a evolução e promover a adoção das MTDs;

- Sempre que solicitado, posicionar sobre questões da sua competência.

O Artigo 9ำ define que a competência para a emissão da Licença é da APA; que a LA faz parte integrante da decisão emitida pela EC relativa ao início da operação da instalação e esta decisão só pode ser emitida após a APA ter deferido o pedido de licença ambiental e remetida a EC.

No entanto, a decisão da EC sobre "o pedido de autorização de instalação pode ser proferida antes da decisão final do procedimento de licença ambiental, que é apenas condição do início da exploração da instalação". Há, pois, concomitância no processamento dos pedidos e da concessão da LA.

Quando o empreendimento é sujeito à avaliação do impacto ambiental, o procedimento é especificado no Artigo 12‥ Nesses casos, a solicitação da LA é precedida do Estudo de Impacto Ambiental, que é pré-condição para que os agentes governamentais façam a AIA.

A Licença Ambiental é entregue ao empreendedor, após atender as seguintes condições:

- A emissão da declaração de impacto ambiental - DIA favorável ou condicionalmente favorável, no caso do procedimento de AIA decorrer em fase de projeto de execução; 
- A emissão do parecer relativo à conformidade do projeto de execução com a DIA, no caso do procedimento de AIA decorrer em fase de estudo prévio;

- A decisão de dispensa do procedimento de AIA, ou;

- O decurso do prazo necessário para deferimento tácito nos termos previstos no regime jurídico de AIA.

Há ainda a hipótese definida no item 3 do Art. $12^{\circ}$ que o procedimento pode se desenvolver simultaneamente com 0 procedimento de prevenção de acidentes graves, envolvendo produtos perigosos, ou com o procedimento da AIA, desde que seja relativo a um projeto de execução.

O Artigo $13^{\circ}$ define as condições de instrução do pedido de LA pela APA e o seu desenvolvimento no tempo.

Para melhor visualização, segue o esquema mostrado na figura 3.1: 


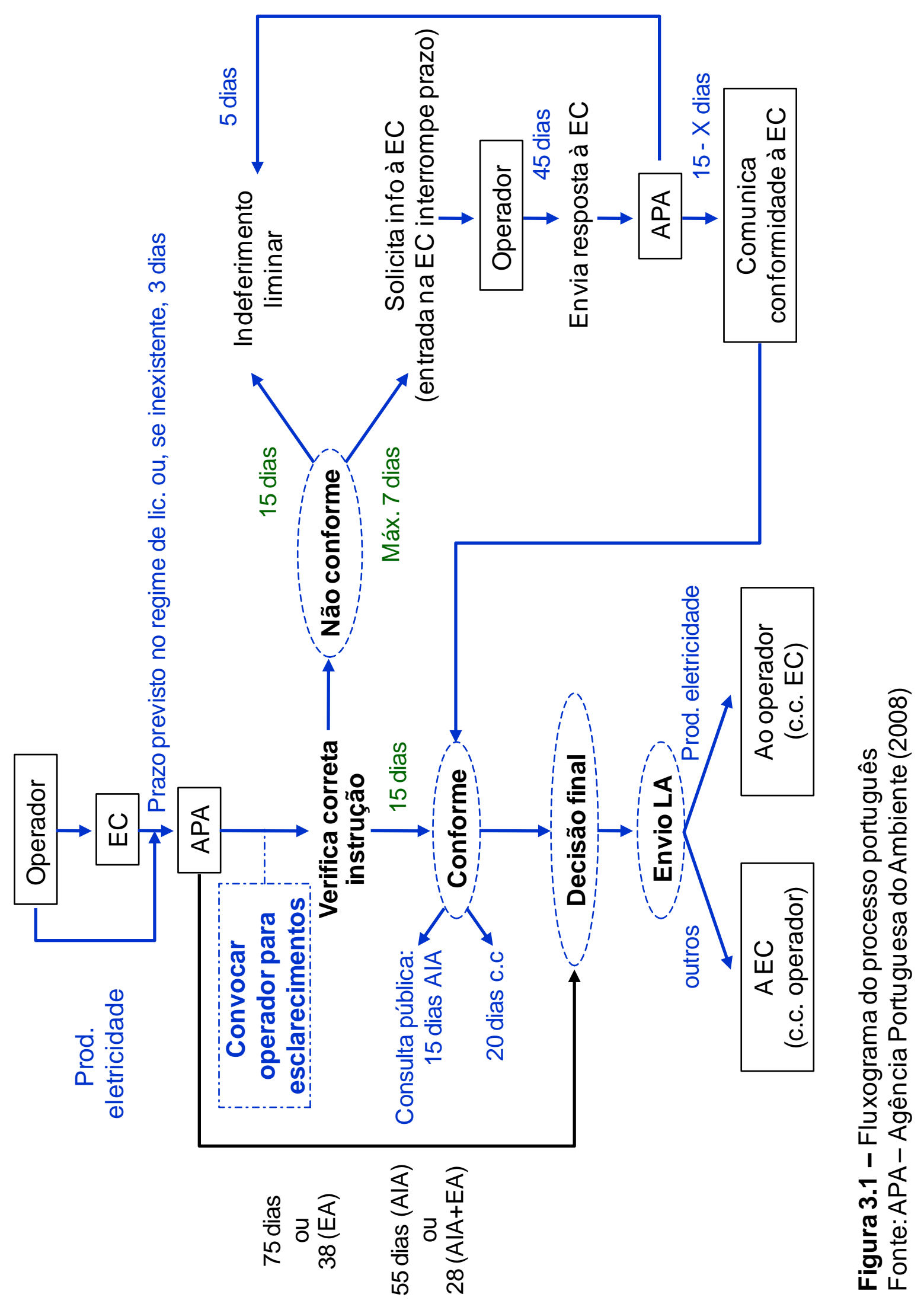


O Artigo $17^{\circ}$ se refere ao deferimento tácito, isto é, se não houver manifestação dos agentes governamentais e não estiver presente nenhuma das causas passíveis de indeferimento descritas no Decreto-Lei, a pretensão do empreendedor é deferida.

E neste caso, a APA emite e remete para o empreendedor certidão comprovante do decurso de prazo para a emissão da LA.

Ao mesmo tempo, a EC, que decidirá pela data do início das operações, deverá certificar-se que não serão ultrapassados os limites de emissão; que as MTDs serão utilizadas e que foram contemplados os requisitos manifestados pela participação popular.

A LA é renovável (Artigo 20), com solicitação por parte do empreendedor nos 75 dias anteriores ao seu vencimento. Tal solicitação é feita diretamente à APA, que dará conhecimento ao EC.

Ao pedido de renovação, devem ser acrescidos os documentos de atualização dos processos industriais que tenham ocorrido no período.

Em seu parágrafo $3^{\circ}$, o Art. 20ํำ explicita:

"o empreendedor deverá requerer, através da EC, a renovação da licença ambiental de instalação sempre que:

- A poluição causada pela instalação for tal que exija a revisão dos valores-limite de emissão estabelecidos na licença ou a fixação de novos valores-limite de emissão;

- Ocorram alterações significativas das MTDs, que permitam uma redução considerável das emissões, sem impor encargos excessivos;

- A segurança operacional do processo ou da atividade exija a utilização de outras técnicas;

- Novas disposições legislativas o exijam". 
Sempre que ocorrer qualquer das situações previstas nos itens anteriores, a APA comunica ao empreendedor, através da EC, a obrigatoriedade de requerer a renovação da licença ambiental fixando o prazo para tal.

A caducidade da licença ocorre em dois anos (Art. 21ํ) se o empreendedor, nesse prazo, não tiver dado início à operação; excetuam-se casos em que haja atraso justificado detalhadamente.

O Artigo $23^{\circ}$ trata da questão da poluição transfronteiriça. Nestes casos, a APA, verificando essa possibilidade, deve transmitir ao Estado vizinho todas as informações constantes do pedido de LA, de forma a que o público desse Estado membro possa se manifestar antes da tomada de decisão relativa ao empreendimento.

Se por outro lado, a autoridade competente de um Estado membro potencialmente afetado pelo projeto, sujeito à licença ambiental, manifestar formalmente a intenção de participar do procedimento de licenciamento, deve ser-lhe facultada toda a informação contida no pedido de licença ambiental.

O Artigo $26^{\circ}$ trata da utilização dos recursos hídricos pelo empreendedor. Neste caso, existem duas alternativas: a concessão é solicitada pelo empreendedor diretamente à Administração da Região Hidrográfica $(\mathrm{ARH})$ e quando da obtenção, ela é anexada ao pedido da licença ambiental; ou a própria APA o faz. Em qualquer dos casos, as duas entidades devem trabalhar coordenadamente para atingir os objetivos e prazos.

É importante ressalvar que o título de utilização do recurso hídrico, embora anexado à licença ambiental, mantém-se como autônomo, ambos independentes um do outro, cada um regendo-se por suas normas próprias.

Para que todo o procedimento seja processado, há necessidade de pagamento de taxas por parte do empreendedor, conforme disciplinado no Artigo $30^{\circ}$.

Essas taxas são divididas na proporção de $30 \%$ para a EC e $70 \%$ para a APA; no entanto, quando o pedido é indeferido liminarmente, o empreendedor recebe de volta $70 \%$ do valor pago para análise do pedido. E no caso de ter decorrido o prazo 
sem que a licença tenha sido emitida ou pela APA ou pela EC, e portanto aprovada por decurso de prazo, as entidades providenciam a devolução integral do valor ao empreendedor.

O procedimento de licenciamento pelas autoridades ambientais de Portugal, sem dúvida, inova em muitos procedimentos e procura melhorar a eficiência do processo de licenciamento tão criticado.

Igualmente importante é a ênfase na obtenção e utilização das melhores técnicas disponíveis, objetivando assegurar a redução das emissões nas quatro principais dimensões do ambiente, quais sejam: o ar, a água, o solo e a redução da produção de resíduos.

\subsubsection{Continente Americano}

\subsubsection{Canadá}

Bleruble; Cusson (2002), analisando o licenciamento ambiental para hidrelétricas, destacam a grande vantagem deste tipo de geração de energia, comparativamente com as térmicas a gás e óleo, não obstante a sua participação no mercado de geração ter diminuído fortemente a partir de 1970. Tal fato tem ocorrido principalmente em função das restrições legais e das condições regulatórias, que tem dificultado o licenciamento ambiental em detrimento de outras formas mais poluidoras.

Com o objetivo de dirimir o problema, a Agência Internacional de Energia (AIE) instituiu um grupo tarefa para "comparar e analisar diversos mecanismos legais em alguns países", levando em conta principalmente os padrões mais efetivos para 0 empreendimento e respeitando os direitos de "terceira geração", entendidos como a promoção dos direitos humanos; a proteção do meio ambiente e o direito a um desenvolvimento econômico.

A principal conclusão que chegou esse grupo tarefa foi que uma reforma nos procedimentos e regulamentos era necessária para evitar alguns desequilíbrios e a inadequada alocação de recursos para os empreendimentos. 
Comparou leis e regulamentos de outros países, incluindo a sistemática dos Estudos Ambientais (EA), sempre levando em conta que o principal objetivo de qualquer empreendimento é atender aos direitos de terceira geração.

Os dilemas éticos, que são próprios do estabelecimento das linhas políticas de ação e que são sempre associados aos empreendimentos, especialmente aos de infraestrutura, não podem ser relegados na análise e se consubstanciam em cinco linhas principais, quais sejam:

- Otimização;

- Administração;

- Probidade;

- Participação popular e

- Prevenção e controle.

Ao nível das decisões políticas, o grupo tarefa ressaltou a necessidade de uma Avaliação Ambiental Estratégica (AAE), que pode ser entendida como um processo sistemático de avaliação global dos empreendimentos na fase preliminar de planejamento; a qualidade ambiental, as conseqüências decorrentes, as diferentes visões dos objetivos do desenvolvimento, todos incorporados num plano ou programa que analise as relevantes variáveis biofísicas, econômicas, sociais e políticas, assegurando que elas estejam totalmente integradas.

A Avaliação Ambiental Estratégica (AAE) - aplicada às políticas públicas assegura melhores condições para o desenvolvimento do EA e acelera o processo de licenciamento, porque foram arbitrados com antecedência os principais interesses dos vários atores envolvidos.

No caso do Canadá, a AAE deve cumprir alguns pré-requisitos, tais como:

- Participação pública para assegurar a legitimidade, pois permite que o público tenha amplo conhecimento da proposta e oferece a oportunidade para que ele também influencie na decisão final, o que dá maior segurança ao processo. 
- Clara distinção entre a política pública para aquele setor e os méritos específicos de cada um dos projetos.

Bleruble; Cusson (2002) citam o caso do Nepal, onde o setor de energia inventariou 138 projetos; uma análise posterior selecionou 44, que foram mais tarde reduzidos para 24, que fizeram parte da avaliação ambiental estratégica e que propiciou, numa fase posterior, o desenvolvimento dos estudos ambientais.

A AAE nem sempre garante a completa aceitação do projeto. Na Noruega, através da AAE, o governo identificou numerosos cursos d'água que necessitavam proteção e se tornaram inelegíveis para um aproveitamento energético; e inúmeros outros, nos quais era possível este aproveitamento.

Embora a AAE tenha se mostrado um poderoso instrumento de suporte à decisão, muitos países ainda não a utilizam.

Definidos os projetos a serem desenvolvidos; a fase seguinte é a do planejamento específico.

Nesta fase, os potenciais benefícios e custos do projeto são comparados através do EIA, que de forma geral, contém os seguintes elementos:

- Identificação do projeto;

- Descrição e avaliação dos efeitos diretos e indiretos;

- Populações;

- Fauna;

- Flora;

- Solo;

- Ar;

- Clima;

- Uso e ocupação do solo; 
- Patrimônio cultural;

- Integração de todos estes fatores.

Essa itemização, estabelecida pela Diretiva Européia 85/337/EEC, é utilizada ainda hoje pela maioria dos países.

Os pontos principais do EIA podem ser definidos como sendo o diagnóstico e a listagem das tarefas a serem analisadas ou plano de referência dos estudos.

O diagnóstico é a fase onde o projeto é analisado segundo seus efeitos ambientais mais significativos, de acordo com a sua natureza, porte ou localização.

Há países que definem a necessidade ou não de EA conforme o porte do empreendimento; no caso do setor elétrico, por exemplo, é comum estabelecer-se um limite, conforme a capacidade de geração de energia elétrica. Tal é o caso do Japão, que exige um EIA para hidrelétricas com capacidade de geração maior que $30 \mathrm{MW}$; para térmicas com capacidade superior a $150 \mathrm{MW}$ e para qualquer capacidade, quando se trata de geração de energia nuclear.

Há, normalmente, uma tendência a se proteger os pequenos empreendimentos. No entanto, os problemas ambientais podem preponderar mesmo nestes casos, tais como nas pequenas centrais hidrelétricas - PCHs. As restrições baseadas unicamente na capacidade de geração nem sempre são adequadas para a análise ambiental e podem apresentar grandes efeitos negativos para o meio ambiente.

A análise de alternativas e o processo onde se avaliam as diversas possibilidades de solução são as fases mais importantes para estabelecer o termo de referência dos projetos específicos.

Deve-se centrar o foco das preocupações na avaliação dos problemas-chave e reduzir o nível de análise em informações irrelevantes, que não devem ser requeridas ao empreendedor, o que na prática, nem sempre acontece. Como consequência, há o encarecimento do projeto e a introdução de preocupações e incertezas entre os empreendedores, o que diminui a previsibilidade do processo. 
É necessário levar em conta que houve na fase anterior, a participação ampla de todos os envolvidos para a tomada de decisão; ao mesmo tempo, procurou-se razoabilidade e confiança no processo, e as autoridades públicas responsáveis analisaram e consideraram todos os aspectos envolvidos.

Há certa tendência de se abrir amplas discussões sobre temas periféricos ao projeto para se evitar controvérsias, e como resultado, há o risco de se aumentar a ineficiência do processo.

A experiência canadense permite concluir, em resumo, que as diferentes fases do projeto se completam com o EIA, não obstante "há crescentes preocupações que os processos de aprovação ambiental de empreendimentos se tornem excessivamente rígidos e onerosos na maioria dos países da OECD (Organization for Economic Cooperation and Development), vez que o Estudo Ambiental é a única via legal de aprovação" (BLERUBLE, 2002).

Os estudos ambientais EA não representam a solução final, mas são indispensáveis para o cumprimento, por parte dos atores envolvidos, das exigências legais no Canadá e nos países da OECD. São tão mais significativos quanto mais adequadas forem as análises e os padrões ambientais ajustados entre as partes.

O objetivo maior do processo dos Estudos Ambientais é a comparação dos potenciais impactos adversos do projeto com seus potenciais benefícios. Muito freqüentemente a "sociedade civil, representada por grupos ambientalistas de interesse, foca somente nos impactos adversos locais." (BLERUBLE, 2002).

Os licenciamentos ambientais no Canadá também são compartilhados, isto é, os entes federados concorrem na questão ambiental, o que significa que há exigências ambientais no âmbito federal, nos estados (províncias) e também alguns acordos laterais estabelecidos mutuamente, como áreas indígenas, a Baia James e do Norte de Quebec, entre outros (BIRD, 2008).

A lei canadense de Avaliação Ambiental estabelece que o processo é federal "sempre que uma autoridade federal tenha uma responsabilidade decisória específica em relação a um projeto" (BIRD, 2008). 
No caso da energia hidrelétrica, é exigida uma avaliação ambiental ou um estudo completo para capacidade geradora igual ou maior que $200 \mathrm{MW}$, ou para uma repotencialização de uma geradora que aumente a capacidade em $50 \%$ ou mais, ou $200 \mathrm{MW}$ ou mais.

A construção de reservatórios ou transposição de bacias para cursos d'água também estão sujeitas a estudo completo.

O Ministro do Meio Ambiente decide se o projeto deve ser encaminhado a um mediador ou a um painel revisor, devolvendo-o à autoridade responsável.

Há uma Agência Ambiental que atua como coordenadora federal na avaliação ambiental, que é a Agência Canadense de Avaliação Ambiental - CEAA.

Há a oportunidade de se estabelecer voluntariamente um processo de negociação, onde um mediador independente e imparcial trabalha para resolver os impasses. Há também a possibilidade de se trabalhar em paralelo com um painel revisor. A experiência tem mostrado que essa prática, legalmente prevista, é raramente utilizada.

Os painéis revisores procuram informar e envolver o maior número de grupos e pessoas interessadas nas audiências públicas. Nessas oportunidades, tanto os empreendedores como os especialistas do governo são ouvidos.

Há também a possibilidade de se formar painéis conjuntos, através de acordo entre as partes, evitando-se duplicidade e maiores atrasos; essa possibilidade é sempre utilizada quando é necessário ouvir mais de uma esfera de governo, por exemplo, federal e estadual.

O governo federal desenvolveu acordos de harmonização ambiental para todo o Canadá, que estabelecem os seguintes princípios e mecanismos de gestão ambiental conjunta: transparência, responsabilização pública, eficiência e certeza do processo de licenciamento.

Esses acordos não delegam qualquer poder de uma esfera de governo para a outra, mantendo cada governo a autoridade nas áreas sob a sua jurisdição e a 
responsabilidade pelas decisões, que são exigidas pela sua própria legislação, portanto, cada esfera de governo retém totalmente sua autoridade no licenciamento ambiental.

O processo de licenciamento ambiental, especialmente no caso dos projetos hidrelétricos, é único e integrado. No entanto, para sua execução, há necessidade de inúmeras licenças, como por exemplo, para construir estradas de acesso, pedreiras, depósito de resíduos, bota fora, etc. podendo chegar às centenas.

Há também a necessidade de se obter outras autorizações junto a outras Agencias governamentais, que são onerosas e/ou demoradas, tais como licenciamentos arqueológicos, florestais, uso e ocupação de solo e as de pesca.

Os tempos médios para o licenciamento ambiental no Canadá são mostrados na Tabela 3.4 (BIRD, 2008).

Tabela 3.4 - Tempos Médios para Licenciamento Ambiental no Canadá

\begin{tabular}{l|c}
\hline 1. Notificação do projeto até o recebimento dos termos de referência & 6 a 12 meses \\
\hline $\begin{array}{l}\text { 2. Recebimento do Termo de Referência até a finalização da } \\
\text { Avaliação Ambiental }\end{array}$ & 18 a 36 meses \\
\hline $\begin{array}{l}\text { 3. Da apresentação do Relatório de Avaliação Ambiental até a } \\
\text { aprovação final do projeto. }\end{array}$ & 6 a 18 meses \\
\hline
\end{tabular}

As tabelas 3.5 e 3.6 ilustram os cronogramas com os prazos usuais das etapas do processo de licenciamento de uma usina hidrelétrica de grande porte e uma de médio porte, respectivamente. 
Tabela 3.5 - Cronograma dos prazos para a finalização do licenciamento ambiental de projeto de empreendimento hidrelétrico de grande porte

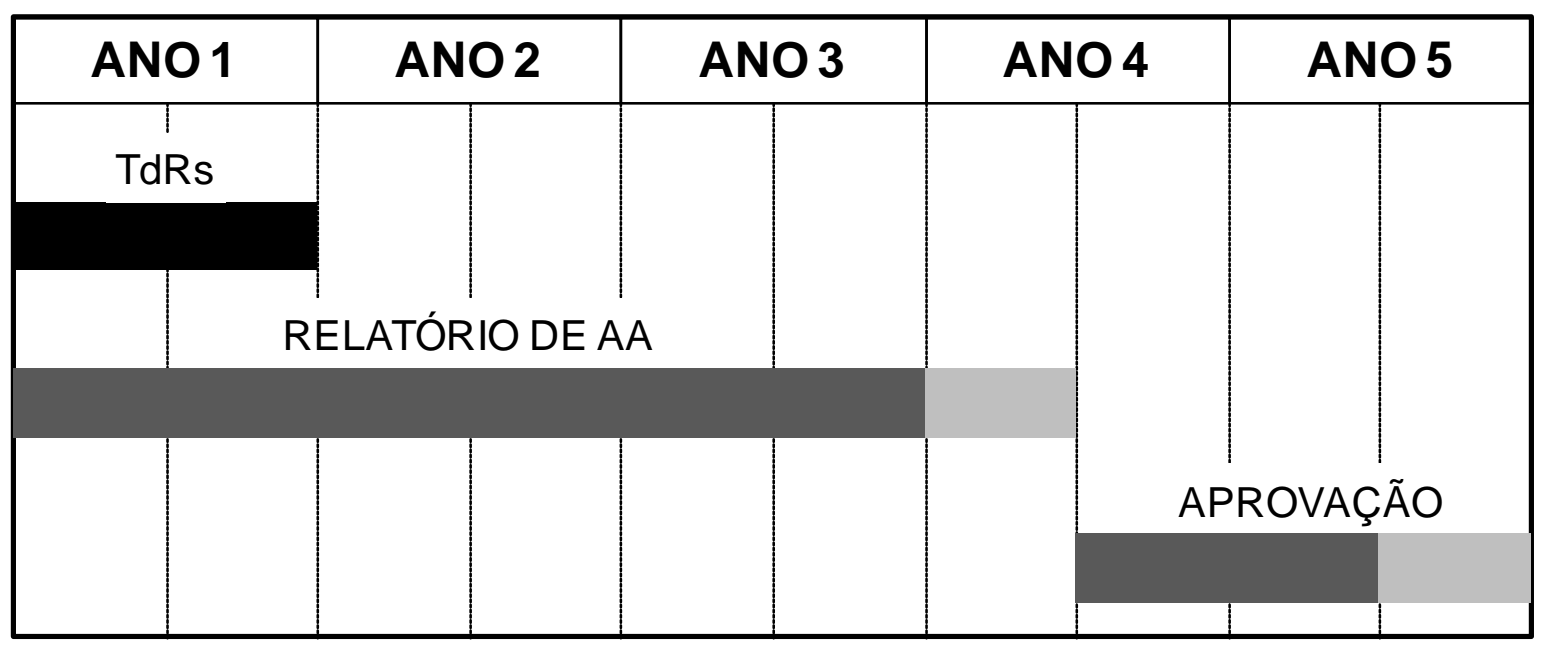

Legenda: TdRs - Termos de Referência

Fonte: Licenciamento do Setor Elétrico (BIRD, 2008)

Tabela 3.6 - Cronograma dos prazos para a finalização do licenciamento ambiental de projeto de empreendimento hidrelétrico de médio porte

\begin{tabular}{|c|c|c|c|c|}
\hline ANO 1 & ANO 2 & ANO 3 & ANO 4 & ANO 5 \\
\hline $\begin{array}{c}\text { TdRs } \\
\text { Thes }\end{array}$ & & & & \\
\hline RELAT & DE AA & & & \\
\hline & & APROVAÇÃO & & \\
\hline & & & & \\
\hline
\end{tabular}

Legenda: TdRs - Termos de Referência

Fonte: Licenciamento do Setor Elétrico (BIRD, 2008)

Os diferentes obstáculos que emergem no processo de licenciamento são mostrados na Tabela 3.7. 
Tabela 3.7 - Obstáculos que emergem no processo de licenciamento

\begin{tabular}{|c|c|}
\hline Obstáculos & Comentários \\
\hline $\begin{array}{l}\text { Incertezas associadas ao processo } \\
\text { de Licenciamento Ambiental }\end{array}$ & $\begin{array}{l}\text { - Fator de risco significativo } \\
\text { - Inibidor de investimentos } \\
\text { - Engajamento da população orientada por grupos } \\
\text { de pressão } \\
\text { - Ausência de padrões e critérios ambientais } \\
\text { - Avaliação ambiental extrapola o escopo, } \\
\text { abrangendo questões macro ambientais e sociais } \\
\text { - Questão fundiária } \\
\text { - Autogoverno das comunidades indígenas }\end{array}$ \\
\hline $\begin{array}{l}\text { Coordenação entre os diferentes } \\
\text { níveis e agências de governo }\end{array}$ & $\begin{array}{l}\text { - Falta coordenação entre os diferentes níveis de } \\
\text { governo e as Agências } \\
\text { - Estabelecer essa coordenação é o maior desafio } \\
\text { atual } \\
\text { - O Acordo de Harmonização Ambiental muito tem } \\
\text { ajudado na superação do problema } \\
\text { - Em } 2005 \text {, foi editada Lei de Avaliação Ambiental - } \\
\text { Coordenador Federal de Avaliação Ambiental, } \\
\text { objetivando aumentar o nível de cooperação. }\end{array}$ \\
\hline Outros obstáculos & $\begin{array}{l}\text { - Tendência de aumentar a responsabilidade legal } \\
\text { e as obrigações do governo federal e de seus } \\
\text { funcionários } \\
\text { - Ações Populares no judiciário } \\
\text { - Responsabilidade legal e até a criminalização dos } \\
\text { proponentes do projeto em relação ao } \\
\text { cumprimento das exigências e na implementação } \\
\text { de medidas. } \\
\text { - Aumento do conteúdo dos EIAs } \\
\text { - Maior importância dada à participação pública e } \\
\text { comunitária } \\
\text { - Ausência de políticas e programas solidamente } \\
\text { elaborados, coerentes e publicamente aceitos. }\end{array}$ \\
\hline
\end{tabular}

Fonte: Bird (2008) 


\subsubsection{Estados Unidos}

Em 1969, foi editado o Ato $n^{\circ} 49$, que estabeleceu a Política Nacional de Meio Ambiente para os Estados Unidos (National Environmental Policy Act - NEPA), objetivando implementar a proteção e a melhoria do meio ambiente e estabelecer os processos para atingir tais objetivos.

Uma das conseqüências dessa lei foi a criação da Agência de Proteção Ambiental americana (United States Environmental Protection Agency - USEPA) e do Conselho para a Qualidade Ambiental (Council for Environmental Quality - CEQ).

O CEQ tem a função de supervisionar a aplicação da NEPA; enviar relatórios diretamente ao Presidente da República e ao Congresso Nacional e avaliar os programas federais estabelecidos nos objetivos da NEPA.

Por sua vez, a USEPA tem como responsabilidades:

- Estabelecer padrões de emissão e de qualidade;

- Conduzir e incentivar o desenvolvimento técnico através de diversos fundos de financiamento;

- Elaborar e revisar todos os Relatórios de Impacto Ambiental federais e

- Acompanhar e avaliar as leis e regulamentos ambientais.

Quando há financiamento de Agência Federal nos empreendimentos, a lei norteamericana estabelece que devam ser analisados os impactos ambientais e suas alternativas, através dos chamados Estudos Ambientais (Environmental Assessments - EAs) ou o Relatório de Impacto Ambiental (Environmental Impact Statements EISs), cujos padrões foram estabelecidos pelo CEQ.

A lei norte-americana estabelece ainda que as ações federais mais significativas relacionadas ao meio ambiente e que recebem financiamentos federais para execução total ou parcial dos empreendimentos são as que envolvem:

- Atividades de energia nuclear; 
- Derivação de águas de rios ou lagos;

- Estradas, pontes, aeroportos, mesmo sendo construídos por autoridades estaduais ou municipais.

A agência federal que tem a responsabilidade de propor o projeto e é responsável pela sua aprovação ou rejeição é a chamada "Agência Líder". E de acordo com a lei, é a responsável pela preparação do Relatório de Impacto Ambiental (RIMA).

Pela lei, as demais agências são chamadas a trabalhar em conjunto com a Agência Líder para assegurar a análise e discussão completa do projeto.

A Agência deve identificar a alternativa ambiental mais adequada e a alternativa preferida pode ou não ser a mesma.

A primeira alternativa é a que causa menor dano ambiental, e a que melhor preserva, protege e conserva os bens históricos e culturais e os recursos naturais.

A segunda alternativa preferida pela Agência leva em conta outros fatores tais como: custos financeiros, planos de uso e ocupação do solo, restrições legais, etc.

A Agência deve expor as suas conclusões se as duas alternativas não coincidirem.

O RIMA é um instrumento legal, preparado pela Agência Ambiental, com a finalidade de propiciar uma decisão política. Embora elaborado em linguagem acessível não científica, é precedido por um relatório científico $(R C)$, que é escrito por uma equipe multidisciplinar, com especialistas de diversas áreas do conhecimento, feito em linguagem seletiva e que não se destina a uma audiência pública. Normalmente, o $\mathrm{RC}$ é revisto por um grupo de especialistas antes de ser publicado em revistas especializadas ou apresentado em congressos científicos. Seus autores são os únicos responsáveis pelo seu conteúdo (BIRD, 2008), mas não são passiveis de serem chamados a uma corte de justiça.

O RIMA deve conter os estudos e modelos que permitam prever as eventuais modificações que ocorrerão no meio ambiente após a execução do empreendimento; são feitas as análises da capacidade suporte do meio, de tal forma que os padrões de qualidade admissíveis não sejam ultrapassados. 
O Chefe da Agência que propôs o RIMA é o responsável pela integridade do Relatório e os técnicos que o elaboraram são responsáveis pelas contribuições que deram nas respectivas especialidades.

Eles estão aptos a discutirem e defenderem suas análises e conclusões se eventualmente, num futuro, uma corte de justiça vier a solicitar.

O Conselho de Qualidade Ambiental estabeleceu o conteúdo mínimo de um EIA, sintetizado na tabela 3.8 
Tabela 3.8 - Conteúdo mínimo de um EIA

\begin{tabular}{|c|c|}
\hline Capítulo & Conteúdo \\
\hline 1 Capa & Titulo do Projeto \\
\hline 2 Sumário Executivo & $\begin{array}{l}\text { Resumo do trabalho, conclusões } \\
\text { Áreas de preocupação que foram identificadas } \\
\text { Problemas que remanesceram } \\
\text { Impactos ambientais que não foram mitigados } \\
\text { Alternativas estudadas }\end{array}$ \\
\hline 3 Índice & Listagem dos capítulos \\
\hline 4 Objetivos & $\begin{array}{l}\text { Ações propostas } \\
\text { Breve histórico do projeto } \\
\text { Leis, padrões a serem atendidos; segurança, políticas que } \\
\text { incidem sobre o projeto }\end{array}$ \\
\hline 5 Estudo de Alternativas & $\begin{array}{l}\text { É a fase mais importante de todo o estudo; } \\
\text { As alternativas estudadas, inclusive as descartadas } \\
\text { devem ser apresentadas de forma concisa e em estudo } \\
\text { comparativo, definindo os problemas enfrentados e as } \\
\text { soluções adotadas, mostrando com clareza as razões das } \\
\text { opções escolhidas; } \\
\text { Tabelas, gráficos e tudo o que contribuir para esclarecer } \\
\text { as semelhanças e diferenças entre as opções; } \\
\text { Custos e benefícios, usos do solo, ciclo de vida, } \\
\text { quantidade da biota afetada, saúde da população, } \\
\text { emissões tóxicas e/ou radioativas; } \\
\text { Relocação de populações, consumo de água e energia. }\end{array}$ \\
\hline 6 Areas Afetadas & $\begin{array}{l}\text { Descrição concisa da área afetada; } \\
\text { Topografia, tipos de solos, geologia, água subterrânea; } \\
\text { Quantidade e qualidade da água a ser utilizada; } \\
\text { Clima, qualidade do ar, vida aquática e terrestre; } \\
\text { População afetada e sua condição sócio-econômica. }\end{array}$ \\
\hline 7.Consequências Ambientais & $\begin{array}{l}\text { Discute os impactos ambientais da alternativa escolhida e } \\
\text { inclusive a alternativa de não ação. } \\
\text { Os impactos durante a fase de construção e na de } \\
\text { operação. }\end{array}$ \\
\hline 8 Pessoal & Lista dos participantes do projeto \\
\hline 9 Apêndice & $\begin{array}{l}\text { Os detalhes finais, tabelas, modelos, estudos, tudo que } \\
\text { possa contribuir para a decisão, inclusive cartas e } \\
\text { memoriais que foram elaborados durante o projeto }\end{array}$ \\
\hline
\end{tabular}

Fonte: BIRD (2008) 
Para a preparação da primeira versão e da final do RIMA, a legislação federal norteamericana estabelece como passo inicial que a Agência Líder faça publicar uma nota sobre o projeto no Diário Oficial (Federal Register - FR), publicação diária do governo federal contendo todos os atos governamentais, suas regras, regulamentos e notícias de interesse público.

A nota é padronizada (notice of intent - NOI) e o processo de licenciamento efetivamente só se inicia após a sua publicação.

A Agência Líder convoca uma ou mais audiências públicas, que normalmente ocorrem no próprio local onde se instalará o empreendimento ou próximo dele. Qualquer pessoa pode apresentar comentários escritos ou oralmente sobre o empreendimento.

As audiências servem para que a Agência informe aos moradores da vizinhança sobre o empreendimento e objetiva também obter seu envolvimento no processo tão cedo quanto possível.

A partir dessas audiências, a Agência Líder indica uma equipe multidisciplinar, formando um comitê de especialistas, para preparar um primeiro esboço do RIMA. É indicado um gerente para o projeto, que atuará como sendo o primeiro contato entre os entes governamentais, quer federais, estaduais ou municipais.

Concluída a primeira versão do documento, ele é impresso e distribuído para os interessados, objetivando obter comentários sobre seu conteúdo e conclusões.

Os comentários são recebidos e respondidos pelo gerente do projeto, utilizando-se do comitê de especialistas. A edição final do RIMA é preparada, impressa, publicada e distribuída para circular aos interessados.

Essa versão final contém como apêndice, entre outros, os comentários e notas enviadas pela população.

A legislação federal norte-americana estabelece três níveis de análises: 
- Exclusão Preliminar

É aplicada quando não se vislumbra potencial de significativos impactos ambientais no curto ou no longo prazo.

\section{- Declaração Ambiental}

É preparada quando a expectativa dos impactos ambientais e sua mitigação são pequenas. Essas declarações não devem ter mais do que 10 a 15 páginas e é acompanhada por uma declaração de insignificantes impactos ambientais (IIA).

A IIA é preparada pela Agência Líder, informando que os chamados insignificantes impactos ambientais resultam das ações propostas de mitigação. Dessa forma, um RIMA não é necessário.

\section{- Relatório de Impacto Ambiental}

O RIMA é exigido se a Agência Líder decide que a proposta de ação pode causar significativo impacto ambiental no meio ambiente, ou se houver controvérsias.

Um RIMA não deve ter mais do que 150 páginas, excluídos os apêndices, abrangendo as ações mais significativas.

Segundo a USEPA, o número médio anual de RIMAs é de 500, e de 10.000 a 20.000 declarações ambientais nas Agências Federais (THERIVEL, 2005).

A legislação norte-americana também discute a diferença entre os efeitos e os impactos ambientais; para o CEQ, os termos efeitos e impactos ambientais são equivalentes, no entanto, Carson (1992) propõe diferenciá-los como segue:

- Efeitos são modificações em alguns parâmetros ambientais, como por exemplo, alterações na qualidade do ar ou da água;

- Impactos, por sua vez, refletem como tais alterações afetam as populações ou o ambiente. Por exemplo: emissões localizadas de uma 
determinada fonte podem provocar horas adicionais de neblina; esse é um impacto atmosférico.

Os diversos atores externos também exercem influência significativa no processo; há ocasiões em que, a despeito de ser permitida em qualquer fase a participação e o acolhimento de sugestão dos diversos interessados, a decisão é levada a uma corte judicial.

É importante identificar as diversas classes de atores externos que podem intervir no processo.

\section{- Favoráveis ao projeto}

São aqueles grupos de interesse que serão diretamente beneficiados pelo projeto caso ele seja aprovado: sindicatos, fornecedores de materiais, equipamentos e serviços, comerciantes locais, profissionais locais que desejam mais empregos na área, etc.

\section{- Diretamente impactados}

Populações que serão diretamente impactadas ou que presumem sê-lo; populações que vivem próximas ao local das construções, que experimentarão maiores ruídos, poeira e tráfego durante o período de construção.

Se a construção for feita num pequeno lugarejo, a própria forma de vida daquela população rural será afetada, modificando seus hábitos.

O projeto pode requerer construção de vila de operários, estradas, pontes, sistemas de saneamento, escolas, comércio para suprimento de alimentos, etc. Pode ocorrer que tais construções não se tornem operacionais ao término da construção, sendo posteriormente abandonadas.

Modelos matemáticos podem estimar, normalmente de forma inadequada, os custos adicionais. Quem pagará e quanto deve ser pago por tais impactos é uma grande e não resolvida questão. 
- Tecnologias alternativas

Este é um grupo que tem grande poder de vocalização de idéias; normalmente, estão associados a alternativas energéticas, como por exemplo, por que não energia hidrelétrica, solar, eólica, biomassa ou geotérmica ao invés da nuclear?

\section{- Conservacionistas de energia}

Esses grupos normalmente advogam uso mais eficiente de equipamentos $\mathrm{e}$ materiais existentes, tentando racionalizar sua utilização.

A conservação de energia deve ser a prioridade primeira de qualquer política nacional. Os países têm buscado com insistência tal política, por exemplo, os Estados Unidos são atualmente mais eficientes do que em 1974, mas os novos apelos de consumo e necessidades da população têm levado a necessidade de substituição dos velhos equipamentos para permitir o atendimento e crescimento de novas necessidades.

\section{- Organizações anti-nucleares}

Advogam que a energia nuclear é muito insegura e deve ser banida, inclusive as usinas já existentes. Essas organizações não consideram que para alguns países a França, por exemplo - é a única alternativa viável e sua substituição levaria a grandes usinas térmicas com combustível fóssil.

Nos EUA, a legislação proíbe a utilização de gás ou óleo para novas plantas térmicas (The Power plant and industrial fuel use act of 1978 - FUE public Law 95620); por sua vez, o potencial hidroelétrico remanescente nos EUA é insignificante e ambientalmente inviável de utilização. Na atualidade, as energias alternativas do sol, do vento, da biomassa e geotérmica não apresentam viabilidade para substituir a energia nuclear e a dos combustíveis fósseis (BIRD, 2008).

Há ainda o agravante que esses grupos ignoram o fato de que as usinas térmicas, utilizando petróleo como combustível, emitem radioatividade para a atmosfera, em grau comparável aos das usinas nucleares (EISENBUD; PETROW, 1964; HULL, 
1974; MCBRIDE, 1978; CARSON, 1992). A radioatividade dos efluentes das usinas térmicas que utilizam como combustível o petróleo, advém da ocorrência natural de subprodutos derivados da queima do petróleo, tais como tório e urânio. Materiais radioativos, tóxicos, e ácidos podem entrar no meio ambiente também através da disposição dos resíduos sólidos oriundos das usinas térmicas (CARSON, 1992).

\section{- Vizinhos}

Muitos grupos não são contrários a um determinado projeto, desde que não afetem seus interesses pessoais. Muitos não querem novas estradas, linhas de transmissão em seus terrenos ou proximidades, fábricas de produtos químicos construídas próximas a seus terrenos. São os chamados $\operatorname{NIMBY}$ (not in my backyard). ${ }^{1}$

\section{- Ambientalistas profissionais}

As decisões de governo, comumente, geram uma nova indústria nos Estados Unidos e noutros países: as indústrias ambientais, muitas vezes chamadas organizações não governamentais ambientalistas. Centenas delas têm sido fundadas especialmente nos EUA, e muitas são pequenos grupos formados para se opor a um projeto específico. Estes grupos devem ser contatados logo no início do projeto, pois eles normalmente são formados por moradores locais e usam o poder judiciário para retardar a implementação do projeto proposto.

Grandes ONGs têm sido criadas por grupos permanentes, muitas poderosas economicamente; algumas se autodenominam grupos de defesa do interesse público e procuram intervir em grande número de procedimentos ambientais. Muitos desses grupos entraram no movimento ambientalista para satisfazer seus ganhos pessoais. Advogados e consultores profissionais têm recebido ótimos dividendos por seus trabalhos nessa área.

Por outro lado, muitos desses grupos atuam adequadamente e protegem a segurança e o meio ambiente.

\footnotetext{
1 Tradução:" Não no meu quintal"
} 
Em conclusão, pode-se afirmar que o RIMA é um documento legal, cuja primeira função é seu uso para a tomada de uma decisão política por parte das Agências Ambientais, aprovando ou não uma determinada proposta. É usado também para informar ao público e a outros órgãos governamentais sobre os impactos que possam ser gerados por um determinado empreendimento.

O RIMA deve ser curto e conciso, conclusivo, deve ser escrito para ser entendido por uma audiência não técnica e deve discutir os prós e contras de uma determinada proposta de empreendimento.

Deve examinar as alternativas das ações propostas, inclusive a proposta de não ação e comparar os impactos dessas diferentes alternativas. Essas análises comparativas representam a essência do RIMA. Elementos que podem ser quantificados devem sê-lo e apresentados de forma a facilitar a sua comparação.

O RIMA é o instrumento fundamental de implementação da legislação ambiental nos EUA, procurando assegurar que as ações modificadoras do meio ambiente sejam mínimas e se limitem a aceitáveis impactos ambientais, ajustando o balanço entre os inevitáveis efeitos adversos com os benefícios auferidos pelo empreendimento.

O processo exigido pelas Agências Ambientais, muitas vezes, dilatam os prazos e aumentam os custos de implementação de uma ação proposta. Grandes somas de horas trabalhadas e custos são investidos no preparo dos documentos, na coleta de dados e informações. O processo também permite que pequenos grupos ou mesmo alguns indivíduos consigam postergar a tomada de decisão.

Os atrasos podem se estender por longos prazos, até um ano ou mais. É imperativa a necessidade de se estabelecer limites legais que restrinjam esse tipo de ação.

É necessário reconhecer, porém, que o processo tem sido exitoso; ao se conseguir diminuir os prazos e custos no processo de aprovação, vai-se alcançar um melhor ambiente e uma melhor condição de vida para a sociedade (CARSON, 1992). 


\subsubsection{Equador}

O Equador possui leis, decretos e regulamentos que remetem a estudos de impactos ambientais. Não tem um sistema ordenado para a elaboração dos EIAs e, portanto, faz exigências individuais nos diferentes níveis de governo.

Entre as diferentes legislações, pode-se destacar:

- Políticas Ambientais Básicas do Equador:

Decreto Executivo o 1802, que estabelece que os EIAs e os correspondentes programas de mitigação dos impactos são instrumentos compulsórios e preventivos para as atividades que podem deteriorar o meio ambiente;

- Regulação para atividades petroleiras no Equador:

Essa legislação exige relatórios dos efeitos ambientais e planos de gerenciamento ambiental para as seguintes atividades: prospecção, exploração, perfuração, produção, transporte, armazenamento e industrialização (ESPINOZA, 2002). Também exige estudos separados para cada atividade e estabelece diferentes requisitos para cada uma delas.

- Em relação a recursos hídricos:

São exigidos EIA para atividades que possam causar efeitos deletérios à saúde pública ou degradação ambiental. Estabelece, também, a descrição das atividades e conteúdos que o EIA deve ter para que seja expedida a licença;

- Em relação ao solo:

É exigido EIA para atividades que possam causar efeitos deletérios à qualidade e deterioração dos solos. Acrescenta ainda que seja especificado e regulado o conteúdo mínimo que deverá ser atingido no controle das atividades;

- Em relação aos resíduos sólidos: 
É exigido EIA para estações de transbordo, tratamento e disposição de resíduos com características especiais e de serviços de saúde e para a disposição final no mar.

Existem inúmeras entidades que, ou por mandato legal ou porque desenvolveram estudos que geraram empréstimos internacionais, posicionam-se diretamente na análise do EIA, tais como:

- Ministério de Minas e Energia;

- Conselho Nacional de Desenvolvimento;

- Subsecretaria de Saneamento Ambiental do Ministério de Desenvolvimento Urbano e Moradia;

- Ministério da Agricultura e Pecuária;

- Conselho Nacional de Recursos Hídricos;

- Diretoria Geral da Marinha Mercante e Litoral;

- Comitê Institucional da Proteção do Ambiente;

- Ministério da Indústria, Comércio e Integração e Pesca;

- Direção Municipal de Higiene e Ambiente do Município de Quito;

- Ministério de Obras Públicas;

- Corporação Financeira Nacional e Bancos Privados;

- Banco do Estado.

Esse conjunto de entidades da administração mostra, por si só, que o processo merece uma revisão nos procedimentos, para que o EIA tenha sua efetividade melhorada. São nada menos do que 12 instâncias burocráticas, trabalhando isoladamente e com visões fragmentadas de um mesmo problema, inserindo distorções e elevação de custos na solução.

A experiência de utilização do EIA no Equador pode ser avaliada nos seguintes tópicos: 
- O Equador não possui um sistema unificado e compulsório para a avaliação dos impactos ambientais, derivados das atividades humanas. As diferentes permissões, oferecidas por diversas instituições, são evidenciadas por inúmeras exigências não uniformizadas;

- A autoridade, que coordena a aplicação das políticas ambientais, tenta estabelecer um sistema de análise para os estudos de impactos ambientais, que poderia integrar os setores público, privado e a sociedade civil;

- Estudos de Impactos Ambientais são solicitados por diferentes instituições, especialmente devido às exigências legais e em particular, por recomendações dos agentes internacionais de empréstimos. Esses estudos não possuem um escopo comum e refletem diferentes demandas e formatos. De uma maneira geral, os ElAs têm sido orientados, basicamente, para fornecer parâmetros mínimos ao invés de concentrar sua ênfase na mitigação dos impactos.

- As regras não são as mesmas para o setor público e privado.

A Corporação Financeira Nacional financia o setor privado, seguindo as orientações do estudo de impacto ambiental. Ela publicou também um manual interno, que regula o conteúdo dos EIAs e introduziu procedimentos para decisões relativamente ao grau de detalhamento requerido nos EIAs.

Tem sido registrado que consultores habilitados têm feito exigências diferentes para termos de referência semelhantes ou vice-versa.

O Equador tem um grande número de guias e parâmetros em relação a proteção da água, do ar e do solo; resíduos sólidos; ruídos; conservação do solo; proteção de florestas; vegetação nativa; fauna e comunidades indígenas, o que deveria facilitar a análise; sabe-se, no entanto, que tais regras não são suficientes para sua autoaplicação e não cumprem com a sua devida finalidade.

Objetivando eliminar as deficiências do sistema, a Câmara Industrial do Equador lançou interessante iniciativa, buscando melhorar a competitividade e a auditoria 
ambiental (PÁEZ, 2003). Para tanto, elaborou um programa de auditoria voluntária para estabelecer quais os principais problemas ambientais que as diferentes indústrias apresentavam; quais as soluções que propunham e qual o grau de dificuldades que cada setor enfrentava na tentativa de resolver as pendências ambientais.

O programa centrou seus objetivos em três pontos:

- Conhecimento e conformidade com as regulamentações ambientais;

- Os principais impactos;

- Gerenciamento ambiental.

Foram escolhidos os três principais estados industrializados do país, quais sejam: Quito, Guayaquil e Cuenca. A adesão ao programa era voluntária e deveriam participar indústrias de diferentes setores e portes. A pesquisa analisou as relações de competitividade e as oportunidades ambientais para implementar um programa de gestão ambiental nas práticas produtivas do país. O projeto foi financiado pela Embaixada da Holanda (PÁEZ, 2003).

Uma equipe independente e multidisciplinar foi formada para atender o escopo do projeto. Constatou de início que o aumento da poluição e a degradação ambiental eram um dos principais problemas no Equador. As tentativas governamentais de resolver a questão se mostraram infrutíferas, não obtendo resposta satisfatória dos setores.

O Equador tem um arcabouço institucional para controle industrial das emissões no ar, para descarga de efluentes, geração de resíduos tóxicos e sua disposição, níveis de ruído, bem como para a definição de procedimentos para a elaboração dos estudos de impactos ambientais, a serem executados antes da fase de implantação de novos empreendimentos.

Embora a legislação tenha sido elaborada há pelo menos dez anos, os resultados são inexpressivos e poucas empresas incorporaram adequadas práticas ambientais em seus processos. 
Alguns pontos foram identificados como restritivos ao desempenho das indústrias:

- Legislação inadequada, uma vez que ela representa essencialmente a transposição da legislação de outros países;

- Fragilidade política e técnica das agências ambientais para a aplicação da legislação;

- Pouca qualificação e experiência em engenharia ambiental, especialmente no que concerne ao controle da poluição;

- Falta de sensibilidade do setor industrial aos problemas ambientais;

- Limitado conhecimento do setor industrial sobre as modernas técnicas de gestão ambiental, como as de prevenção da poluição e sistemas de gerenciamento ambiental.

Mesmo com todas essas limitações, pôde-se constatar, especialmente no setor público, um aumento do comprometimento com as questões ambientais, e também tem sido notado um crescente engajamento das populações na temática ambiental, o que imprime pressões nos agentes públicos.

A comunidade científica, os agentes públicos, as ONGs e o setor industrial têm mostrado interesse em reformular a legislação ambiental, incorporando nela padrões baseados nas condições locais e a utilização de modernas técnicas no gerenciamento ambiental industrial, que poderia também incluir incentivos econômicos.

A recente crise econômica tem postergado essas atitudes vez que os setores industriais estão, no momento, mais preocupados com a própria sobrevivência.

A operacionalidade do projeto foi estabelecida pelo próprio setor industrial e pelo Diretor do Programa. Selecionaram-se quinze indústrias, que responderam voluntariamente ao convite a elas formulado, e que representavam os seguintes setores: carnes, processamento de alimentos, madeira, papel e celulose, plásticos, tintas e solventes, olarias, produtos metálicos, produção de flores, plantação de arroz, produtos da pecuária. 
Foram feitas entrevistas com os gerentes de cada empresa, inspeções nos processos industriais, coletas de informações ambientais e de amostras líquidas, sólidas e gasosas e medição de ruídos.

Foram realizadas diversas oficinas de trabalho com os diferentes setores envolvidos; analisados os diferentes impactos causados e as oportunidades de mitigação; estabelecida uma escala de valores de zero a cem, procurando situar as diferentes indústrias no espectro: baixo impacto, médio impacto e alto impacto (PÁEZ, 2003).

Para o estabelecimento dessa graduação, foram analisados quinze indicadores:

- Prioridade das questões ambientais para a empresa;

- Inserção das práticas ambientais nas rotinas da empresa;

- Incentivo ao desenvolvimento da gestão ambiental;

- Estabelecimento de uma política ambiental;

- Conhecimento dos impactos ambientais derivados das atividades da empresa;

- Definição de metas e objetivos ambientais;

- Definição das responsabilidades pela implementação do plano ambiental na estrutura organizacional da empresa;

- Existência de programas de treinamento;

- Informações aos consumidores sobre os produtos e serviços;

- Compartilhamento das práticas ambientais adotadas pela empresa com os fornecedores e prestadores de serviços;

- Informação à comunidade vizinha sobre os impactos e riscos associados à atividade da empresa;

- Alterações nos processos para a prevenção e o controle da poluição;

- Existência de planos de contingência no caso de eventuais emergências; 
- Implantação de programas e protocolos de monitoramento;

- Existência de documentação ambiental e indicadores de controle.

Para a avaliação final, cada um desses parâmetros recebeu notas de um a cinco, que agregados para cada indústria, possibilitou fazer a classificação final.

$\mathrm{Na}$ conclusão do programa, que mostrou um pequeno universo das indústrias no País, ficou evidente a necessidade de estabelecer novos esforços orientados para prevenção da poluição dentro das indústrias equatorianas, e ficou claro que:

- A simples existência de leis ambientais não implica num melhor desempenho ambiental. São necessários que, na formatação dos regulamentos, todas as partes estejam envolvidas e sejam discutidos os objetivos, em estreita colaboração entre os diversos atores;

- Existem vários problemas de informação no setor industrial sobre modernas técnicas de gestão ambiental e esta é uma das principais causas do baixo desempenho ambiental. É, pois, imperativo criar uma consciência ambiental, baseada na gestão integrada entre produção e meio ambiente, para que as questões ambientais possam vir a ser uma prioridade para o setor industrial do Equador.

\subsubsection{Chile}

O sistema chileno de avaliação ambiental foi concebido para de um lado valorizar os ganhos ambientais e de outro, minimizar, atenuar ou combater os aspectos negativos dos impactos ambientais.

Sua base legal está consubstanciada na Lei oㅜ 19.300, denominada Base Geral para o Meio Ambiente; esta lei foi aprovada em 1994 e regulamentada em 1997. Dessa forma, o sistema chileno está estruturado da seguinte forma:

- Há um conjunto de projetos para os quais o ElA é compulsório; 
- Existem critérios que permitem definir os contornos de viabilidade dos projetos através de duas dimensões: uma técnica e outra administrativa. Estas dimensões permitem estabelecer quatro formas de análise dos processos, conforme tabela 3.9.

Tabela 3.9 - Dimensões de análise dos EIAs

\begin{tabular}{l|c|c}
\hline \multirow{2}{*}{ Dimensão 1 } & \multicolumn{2}{|c}{ Dimensão 2} \\
\cline { 2 - 3 } & Teoria & Prática \\
\hline Plano/Projeto & CAT.1 & CAT.2 \\
\hline Resultados & CAT.4 & CAT.3 \\
\hline
\end{tabular}

Fonte: LASTRA (2003)

Categoria 1 (CAT.1) - Analisa o projeto na perspectiva administrativa

Categoria 2 (CAT.2) - Analisa o projeto em relação às melhores práticas

Categoria 3 (CAT.3) - Analisa a participação popular e/ou pesquisa de atores chaves no processo.

Categoria 4 (CAT.4) - Analisa a qualidade do EIA do ponto de vista da sua documentação legal, seu contexto organizacional e cultural.

- Há um procedimento administrativo que define as funções das diferentes entidades envolvidas no processo CONAMA ou COREMAS, e os prazos de tramitação dos processos. No caso de EIA, o prazo máximo é de 95 dias, incluindo nele as eventuais complementações e a emissão da licença (LASTRA, 2003).

De acordo com a legislação, o impacto ambiental é definido como a alteração direta ou indiretamente produzida ou induzida pelo projeto ou por atividades numa determinada área. Este fato é avaliado através de um relatório ou estudo de impacto ambiental (ESPINOZA, 2002).

O procedimento se inicia com uma lista de projetos e atividades que devem ser avaliadas que, por suas características particulares, são definidas como aquelas que têm, normalmente, um significativo impacto ambiental.

O EIA é exigido tanto para as entidades públicas quanto para privadas. 
Se um determinado investimento pretende ser feito numa atividade incluída na lista, ele deve ser submetido ao sistema de relatório de impactos ambientais; por outro lado, se ela não consta na lista, não se exige o relatório, embora o empreendedor possa voluntariamente submetê-lo ao sistema de análise. Em qualquer dos casos, as leis ambientais devem ser cumpridas integralmente e, quando não há parâmetros chilenos, as autoridades ambientais determinam que os parâmetros suíços sejam usados como referência.

Quando é definido que o empreendimento ou atividade deve ser submetido ao sistema, o passo seguinte é definir se o estudo de impacto ambiental ou o relatório de impacto ambiental são instrumentos capazes de servir para uma correta avaliação.

A Lei, em seu artigo 11, estabelece que devam ser seguidos os seis critérios, discriminados a seguir, para avaliar o significado dos impactos:

- Risco para a saúde das populações, devido à quantidade ou qualidade dos efluentes, das emissões ou dos resíduos;

- Efeitos adversos em quantidade e qualidade para os recursos naturais renováveis, incluindo solo, água e ar;

- Reassentamentos de populações ou significativas alterações no estilo de vida ou hábitos das populações afetadas;

- Estar localizados próximos a núcleos populacionais, recursos ou áreas protegidas, que possam ser afetadas, assim como em áreas de valor ambiental significativo;

- Significativa alteração na paisagem ou áreas de valor turístico em termos de grandeza e duração;

- Alteração em monumentos e sítios arqueológicos, antropológicos ou históricos de valor, e de uma maneira geral, ao patrimônio cultural.

Se o empreendimento não envolver significativo impacto ambiental, o proponente deve submeter o relatório de impacto ambiental, indicando que o projeto cumpre com os regulamentos ambientais em vigor e que não haverá nenhum dano adverso 
ao meio ambiente. Esse documento pode conter também propostas de ações voluntárias, que melhorem o meio ambiente e que se tornarão compulsórias, uma vez aprovadas pelas autoridades competentes.

A lei estabelece com clareza as responsabilidades e as instituições públicas atuam como orientadoras e revisoras. A Agência executora é responsável pela avaliação e pode ouvir uma terceira parte, se tal fato se mostrar apropriado.

O gerenciamento do sistema é feito pelo CONAMA, baseado na institucionalização alcançada pelo país. Ele, CONAMA, coordena e inspeciona a aplicação do sistema; usa a capacidade instalada nos diversos setores do Estado e compartilha sua experiência.

O Diretor Executivo do CONAMA é responsável pela instalação e operação do sistema, bem como para dirimir qualquer eventual controvérsia ou disputa que possa surgir durante a fase de avaliação ambiental.

O Comitê consultivo do CONAMA tem como atividade o envolvimento com os estudos de avaliação, vez que é o responsável pelo estabelecimento dos padrões e definições nos regulamentos de interesse do sistema, e também é consultivo, quando requisitado pela Diretoria, em casos onde há divergências que possam aparecer durante a fase de revisão.

As COREMAS são aquelas que qualificam os estudos após receber as contribuições de entidades públicas e de serviços, bem como observações e propostas oriundas da comunidade e das ONGs. As COREMAS podem ser classificadas como escritórios descentralizados do CONAMA. Elas são chefiadas por funcionários "intendentes" assessorados por um diretor regional e por secretarias regionais do Ministério, que formam o Comitê de Diretores do CONAMA.

Há também um Comitê Técnico, integrado por diretores regionais, legalmente autorizados para rever os estudos e avaliações de impactos ambientais. Se o projeto afetar duas ou mais regiões, o CONAMA operará o sistema em nível nacional.

Interessante aspecto é que o sistema de avaliação dos impactos ambientais incorpora instituições setoriais. Qualquer ministério, com jurisdição legal no 
empreendimento em análise, deve participar conjuntamente nas decisões envolvendo as análises de impacto ambiental.

O sistema é baseado no conceito que uma vez que o estudo de impacto ambiental foi aprovado, a licença é concedida (ESPINOZA, 2002).

Nos municípios onde o projeto será implantado, as prefeituras deverão disseminar o resumo do EIA, que deverá ser publicado a expensas do empreendedor. Ele também publica a lista de atividades que foi desenvolvida no mês anterior, preparada pela COREMA ou CONAMA, nos casos em que alguma ação ou atividade possa comprometer o meio ambiente. As prefeituras são normalmente parte incluída na qualificação dos EIAs.

O sistema chileno é recente. Em 1990, o CONAMA estabeleceu as bases para os projetos e o conjunto de estudos para a avaliação e prevenção dos impactos ambientais no país. A efetividade das ações começou em 1993 com o Decreto Presidencial, que estabeleceu que os EIAs seriam voluntários, o que perdurou até 1997, quando a Lei 19.300 foi promulgada com sua regulamentação que estabeleceu as bases gerais da política nacional.

O processo emergiu em resposta às demandas da população e uma construção coletiva de conhecimentos se estabeleceu a respeito do processo de elaboração do EIA no Chile.

Suas características básicas são:

- É um sistema voluntário;

- O procedimento é baseado na lei 19.300;

- Os procedimentos são incompletos, vez que tópicos importantes ainda estão sendo desenvolvidos, tais como participação da sociedade e 0 uso da avaliação dos impactos ambientais (ESPINOZA, 2002).

A primeira experiência chilena de AIA se referiu à construção de uma fábrica de celulose, na região sudeste do Chile (ALID, 2003). 
A fábrica teria seus efluentes lançados no rio das Cruzes, em uma área protegida pelo projeto RAMSAR ${ }^{2}$.

A escolha do local foi influenciada principalmente pela facilidade propiciada pela bacia do rio das Cruzes, onde ocorria facilidade de obtenção de água e também para diluição dos efluentes. Outro atrativo era de ordem econômica: este projeto daria ao País competição no mercado internacional de papel, visto que sua economicidade também estaria assegurada pela proximidade de florestas, garantindo a matéria-prima para a celulose.

A legislação chilena à época oferecia a oportunidade de serem voluntários os EIAs, e a magnitude do projeto com seus atrativos econômicos propiciava a condição de se fazer uma ampla avaliação ambiental dos seus impactos.

O projeto foi incluído voluntariamente no sistema de avaliação dos impactos ambientais em outubro de 1995 e foi aprovado em maio de 1996. Os procedimentos de avaliação representaram o resultado da experiência de dois anos, tanto do setor público quanto do privado, que foi quem conduziu o EIA e o apresentou às autoridades para a correspondente análise e eventuais revisões. Para a elaboração do mesmo, as autoridades elaboraram um Termo de Referência - TR, que estabeleceu um conjunto mínimo de tarefas que deveriam ser realizadas no referido EIA.

O EIA desse projeto se desenvolveu no tempo em que o Chile ainda apresentava omissões na sua regulação ambiental e não havia procedimentos consistentes para orientar as questões ambientais em estudo (ALID, 2003).

Mesmo assim, o Sistema de Avaliação dos Impactos Ambientais supriu a Comissão Regional do Meio Ambiente (COREMA) com informações suficientes para que as autoridades tivessem segurança na aprovação do projeto.

Foi apresentada uma série de requisitos que deveriam ser cumpridos pelo projeto tais como: análises técnicas, avaliações de pontos de objeção da comunidade,

2 Convenção RAMSAR - Iran 1971 - Tratado intergovernamental para proteção de áreas húmidas. 
definição de medidas mitigadoras, planos de remediação, avaliações ambientais sistemáticas ao longo do período de execução do projeto.

Cumpridas tais exigências, o projeto não só receberia a aprovação, mas também a correspondente licença ambiental.

Muitas críticas foram apresentadas ao TR elaborado pelas autoridades, especialmente quanto às omissões de estudos relativos às condicionantes da vida aquática na bacia; quanto às emissões futuras de $\mathrm{SO}_{2}$, que se transformariam em ácido sulfúrico e também quanto ao manejo e disposição dos resíduos sólidos.

Deve ser analisado o contexto em que tal projeto foi apresentado: a legislação ainda era incipiente e o EIA foi desenvolvido paralelamente à sua elaboração. Alguns pontos devem ser considerados (ALID, 2003):

- O TR é o instrumento básico de preparação do EIA e que deve contemplar as variáveis ambientais envolvidas, lembrando sempre que pode e deve ser estendido, pois o TR é uma lista de tarefas mínimas;

- De acordo com a Lei Ambiental, as autoridades têm 120 dias para análise do projeto, tempo em que, se aprovado, a licença ambiental deve ser expedida;

- O EIA é analisado por autoridades de diferentes departamentos, que devem trabalhar integrados. Participaram da revisão as seguintes autoridades: Departamento Regional de Planejamento e Coordenação, Departamento Regional de Água, Departamento Regional de Estradas, Habitação e Desenvolvimento Urbano, Instituto Nacional de Florestas, Serviço de Agricultura e Pecuária, Serviço Nacional de Pesca, Serviço Nacional de Turismo, Serviço de Saúde Pública de Valdivia, e Departamento de Territórios Marítimo e Mercante;

- Todas essas autoridades analisaram o ElA em função do TR à luz dos seus respectivos critérios setoriais; enviaram seus comentários ao CONAMA, com solicitação de esclarecimentos ou de revisões para que ele fosse devidamente entendido. 
O CONAMA utilizou as informações encaminhadas para preparar o relatório em que solicitou ao empreendedor esclarecimentos ou modificações, nos pontos mais importantes do estudo. Após terem sido esclarecidos e/ou feitas as revisões necessárias, com a solução dos problemas apontados, o CONAMA preparou a primeira versão do relatório, que focou os principais pontos de natureza ambiental, e os requisitos necessários pelos regulamentos ambientais, o que permitiu a emissão da correspondente licença ambiental.

Ponto importante na análise foi o fato de o projeto estar situado $30 \mathrm{~km}$ à montante da área de proteção do RAMSAR, alimentada pelo rio das Cruzes. O Chile ratificou a conferência de RAMSAR em 1981, e o Instituto Nacional de Florestas é o gestor da área preservada.

A situação da reserva natural do rio das Cruzes recebeu atenção do Chefe do Departamento Especial de Política do Ministério de Relações Exteriores, procurando esclarecer como o Chile cumpriria os compromissos internacionais assumidos quanto à Reserva em questão. Esses compromissos incluíam proteção efetiva e a preservação da condição de singularidade dessa reserva única. Após consulta a diversas entidades públicas sobre a Reserva, o Departamento concluiu que a execução do projeto iria gerar impactos em detrimento do meio aquático e sua biodiversidade, o que representaria uma violação aos compromissos assumidos.

Iniciou-se, então, uma revisão dos estudos, acompanhados por informações oriundas de diversas ONGs, que se preocupavam com essa questão. Cientistas e ONGs veementemente argüíram que os efluentes que seriam lançados no curso d'água fortemente impactariam a biota aquática, o que impediria a viabilidade.

Por outro lado, os grandes investimentos feitos, a expectativa de geração de empregos que seria frustrada caso o projeto não se materializasse numa região que estava fortemente impactada por depressão econômica, que seria revertida com a implantação do empreendimento, implicaria em grande frustração social.

Com todos esses fatores em análise, o CONAMA emitiu um relatório técnico, à luz das informações disponíveis pelo EIA e se declarou sem condições de classificar o 
projeto como ambientalmente viável, uma vez que ele falhou em demonstrar que estava conforme os regulamentos ambientais vigentes.

Não obstante, na instância do COREMA, houve a decisão pela aprovação do projeto; com o estabelecimento de diversas restrições ambientais e com a obrigação de avaliar ambientalmente diversos aspectos.

As condições impostas pelo COREMA ao projeto foram às mesmas que estavam estabelecidas no EIA e no relatório técnico do CONAMA, com o acréscimo de que haveria a necessidade de aprimorar o tratamento dos efluentes lançados no rio das Cruzes; enquanto no EIA estabelecia-se os tratamentos primário e secundário dos efluentes, seria exigido agora o tratamento terciário, mas oferecia a alternativa ainda de lançar os efluentes em outro corpo receptor que não o rio das Cruzes.

As outras condições estabelecidas já anteriormente estavam definidas como seguem:

- Resíduos sólidos - aterro sanitário controlado;

- Consumo de água - 900 L/s para água de processo e resfriamento;

- Emissões para atmosfera - recomendação de controle do $\mathrm{SO}_{2}$;

- Plano de monitoramento e acompanhamento.

Há que se analisar as diversas lições deixadas por esse estudo.

Em relação ao TR:

- Número extenso de estudos exigidos e desenvolvidos desnecessariamente;

- Os aspectos relevantes do projeto foram identificados durante a fase de revisão do EIA e não durante a preparação do TR;

- Perda de tempo e de recursos por informações irrelevantes e não aplicáveis e que continuaram a ser analisadas ao invés de serem descartadas; 
- Apresentação segmentada dos impactos ambientais, não levando em conta suas interrelações e sinergias ou seus efeitos acumulados com a combinação de fatores tais como emissões e descargas;

- As autoridades competentes devem decidir com base nas informações estabelecidas no relatório técnico, preparado por entidades competentes, e levando em conta os relevantes aspectos do desenvolvimento regional, fatores sociais e políticos, entre outros;

- TRs devem ser adaptados a cada projeto específico e contemplar e identificar os relevantes impactos a priori antes da avaliação ambiental. Eles devem ser claros em definir áreas nas quais a autoridade deve concentrar suas principais preocupações.

\subsubsection{Peru}

Trata-se da exploração de uma reserva de gás, projeto CAMISEA, na Amazônia Peruana, local onde vivem diversas comunidades indígenas. O projeto certamente exporia tais comunidades a um grande número de impactos ambientais, bem como exigiria modificações nas suas características sociais, culturais e do próprio estilo de vida (SHOOBRIDGE, 2003).

Uma vez implantado o projeto, ele transformaria o Peru num país exportador de energia. Consistia de $600 \mathrm{~km}$ de tubulações, que atravessavam os Andes até se atingir a costa; diversas estações de pressurização e um terminal marítimo no oceano Pacífico.

A legislação peruana exige que projetos de infra-estrutura com esse porte sejam precedidos da correspondente AIA. Tais estudos devem ser executados, como não poderia deixar de ser, logo na fase inicial de planejamento. Este é o primeiro passo de um extenso programa de proteção ambiental, que deve acompanhar todas as diferentes fases do projeto: planejamento, execução, operação e monitoramento da operação. 
No caso particular, a maior dificuldade estava no fato do projeto afetar uma área habitada por grupos indígenas, isolados e semi-isolados, e populações ribeirinhas. Era importante que os impactos não propiciassem perda das tradições culturais e costumes e especial atenção também deveria ser dada aos impactos secundários que poderiam advir, provocando o uso inadequado e insustentável do meio ambiente.

O processo iniciou-se com a contratação de uma consultoria independente e ocupou todo um ano de trabalho, no qual se procurou identificar as questões relativas ao meio físico, biológico e sócio cultural.

As grandes questões relativas ao meio ambiente foram contempladas no Estudo, mas o desafio maior era a participação popular. Por esta razão, foi desenvolvido um amplo programa de consultas com os seguintes objetivos:

- Desenvolver e manter um aberto e transparente diálogo com todas as partes que tinham interesse ou poderiam influenciar no projeto;

- Ser interativo e flexível, de forma que as contribuições pudessem alimentar continuamente o processo e demonstrar como, quando e por que as contribuições dos parceiros seriam ou não utilizadas;

- Aprender com a experiência dos parceiros;

- Manter consulta permanente com os parceiros durante as fases de planejamento, projeto e operação do empreendimento;

- Perceber que havia diferentes níveis de entendimento entre diferentes parceiros e desenvolver programa de consultas compatíveis com essas diferenças;

- Providenciar informações completas do projeto, especialmente no que se referia às questões de métodos construtivos, projeto de engenharia, de operação e as correspondentes medidas de mitigação necessárias.

Por outro lado, os parceiros deveriam exercer as seguintes atividades:

- Consultar as comunidades nativas; 
- Consultar as federações de comunidades;

- Consultar as entidades governamentais;

- Consultar as ONGs nacionais e internacionais.

Com cada uma delas, a linguagem deveria ser diferente. Por exemplo, enquanto que para uma ONG internacional, podia-se usar um modelo tridimensional para exposição, para as comunidades indígenas, houve a necessidade de expor o projeto através de pinturas feitas em papel.

Foram feitas apresentações da AIA na região de Camisea, a federações de líderes e a outros grupos de interesse na capital peruana, na Europa e nos Estados Unidos.

Após o encaminhamento da versão final da AIA às autoridades, o processo de aprovação obedeceu aos trâmites normais de divulgação a todos os interessados.

Cópias em linguagem simplificada, isto é, não técnica, também ficaram disponíveis aos interessados, e neste caso foram distribuídas às comunidades indígenas envolvidas, para acrescentar seus comentários.

No prazo de 60 dias após o recebimento da AIA, o Ministério de Minas e Energia convocou audiência pública. Foram convidados todos os que de alguma forma contribuíram ou seriam afetados pelo projeto. Paralelamente, foram feitas diversas oficinas de trabalho com as entidades da sociedade civil, ONGs, federações das comunidades indígenas e empreendedores, com o objetivo de treiná-los nas técnicas de elaboração da AIA.

Ao final do processo, pôde-se concluir que os diferentes objetivos foram atingidos; as inspeções aos locais do projeto foram produtivas, indo ao encontro das comunidades afetadas. Reuniu-se também um conjunto valioso de informações locais. Puderam ser apresentados às comunidades os conceitos do trabalho da AIA, e estabeleceram-se mecanismos de consulta permanente. Assim, foram identificadas as principais preocupações da comunidade em relação ao projeto (SHOOBRIDGE, 2003).

As preocupações sócio-econômicas do projeto estavam concentradas na possibilidade de interferir negativamente na saúde, na educação e nos processos 
agrícolas locais; muitas comunidades poderiam adquirir novas doenças, novos hábitos de consumo de alimentos e novas formas de produção dos mesmos. Os empreendedores agregaram a seus custos, essas preocupações e os projetos delas decorrentes.

As maiores dificuldades estavam centradas no meio ambiente:

- Poluição das águas e geração de resíduos durante a fase construtiva e como o recurso hídrico e os resíduos seriam gerenciados;

- Uso de lanchas, cujo tráfego e ruído poderiam causar a diminuição da população de peixes (esta era a principal fonte de proteína das populações ribeirinhas) e alterar o estilo de vida dos indígenas.

- Controle de acesso às estradas: as comunidades manifestaram apoio à abertura de estradas, mas somente daquelas que possibilitassem ligações entre as diferentes comunidades, facilitando trocas e comunicações. No entanto, foram inflexíveis quanto ao controle das estradas, alertando que não admitiriam a entrada de madeireiros e colonos em suas terras;

- Quanto aos helicópteros, as comunidades indígenas manifestaram suas preocupações quanto ao aumento dos níveis de ruído, que poderiam afetar a vida selvagem e conseqüentemente seu potencial de caça. Além disso, eles acreditavam que os helicópteros viriam tirar a "gordura das crianças para produzir combustível para os vôos", o chamado mito de "pishtaco";

De uma maneira geral, todas as comunidades entenderam que a AIA ajudaria a proteger o meio ambiente. Dessa forma, o processo de consultas às comunidades foi sendo sempre aprimorado e incentivado. Forneceram diversos parâmetros de análise: coleta de dados no campo, metodologia para trabalhos no campo, impactos nos aspectos logísticos (tráfego das lanchas no rio), participação das comunidades nativas, participação dos parceiros durante a fase de implementação e operação do projeto e programas de treinamento através da disseminação das informações e de oficinas de trabalho. 
Como resultado final, pôde-se observar:

- Ausência de oposição ao projeto;

- A comunidade aceitou o trabalho através de lanchas no rio para o transporte de materiais e equipamentos e participou intensamente no estabelecimento de uma "norma para segurança de tráfego no rio";

- Algumas alterações no projeto, como a da estação de pressurização de gás Las Malvinas, foram introduzidas após diversas oficinas de trabalho, onde houve intensa participação comunitária;

- A comunidade foi hábil o suficiente para ajustar um plano de aquisição e aluguel de terras como medidas compensatórias;

- A comunidade compreendeu os impactos que adviriam da execução do projeto e como tais impactos a afetaria de forma negativa ou positiva. Houve ainda maior compreensão de como ela poderia participar na sua construção e operação.

- Os riscos da construção das tubulações, com as medidas apropriadas de mitigação empregadas, foram também preocupações comunitárias, bem como os planos de gestão, em particular aos materiais tóxicos e resíduos perigosos;

- As comunidades agrícolas locais também perceberam que maior atenção deveria ser dada às comunidades nativas, especialmente nas discussões dos benefícios e das compensações.

As conclusões finais do trabalho da AIA podem ser assim sintetizadas (SHOOBRIDGE, 2003):

- Estabelecer um programa contínuo e permanente de consultas;

- Avaliar e monitorar continuamente a evolução do processo;

- Estabelecer estratégia e métodos de motivação das comunidades locais para os processos de consulta, especialmente entre as mulheres e idosos; 
- Estabelecer o foco das apresentações em dois ou três tópicos ao invés de tentar abranger um grande número de aspectos;

- Fazer apresentações curtas, claras, concretas e escrever uma ata ao final de cada apresentação;

- Estabelecer um método de incentivo às manifestações das lideranças durante as reuniões;

- Utilizar ao máximo, materiais complementares na apresentação, tais como audiovisuais e materiais impressos;

- Esclarecer as comunidades sobre os pontos-chave da AIA;

- As autoridades locais e os titulares da contratação da AIA devem participar de todas as apresentações;

- Implantar programas de treinamento e de educação ambiental, focando nos conhecimentos e tentando sensibilizá-los sobre as épocas de reprodução das fêmeas de caça, das espécies raras e ameaçadas de extinção, dos perigos da caça predatória e do manejo da fauna em geral;

- Incentivar o reflorestamento;

- Estabelecer controle de migração de populações exógenas, usando lideranças da comunidade como guardiães;

- Incentivar as ligações comerciais com as comunidades vizinhas;

- Desenvolver planos de controle de cheias dos rios e de contingenciamento no caso de enchentes;

- Definir planos de vôos para os helicópteros, com controle restrito, para evitar aproximação às comunidades. 


\subsubsection{Costa Rica}

Neste item, será exposto o caso da construção de uma usina hidrelétrica, chamada Toro, numa região circundada por áreas de preservação, com grande potencial turístico e onde a avaliação de impacto ambiental teve grande importância.

Foram estabelecidos vários estágios para o gerenciamento ambiental do projeto:

- Estudos do impacto ambiental e sua avaliação;

- Monitoramento ambiental durante a fase de construção;

- Monitoramento ambiental durante a fase de operação;

- Continuidade do monitoramento na fase de operação.

As maiores preocupações estavam centradas na fase de construção, onde os impactos seriam maiores, embora muitos fossem de curto prazo e tivessem a duração desta fase.

É importante salientar que na construção de empreendimentos e obras de infraestrutura de grande porte em particular, as avaliações dos impactos ambientais devem ser realizadas na fase de concepção dos projetos (PERALTA, 2003).

Neste projeto, o Instituto de Projetos Hidrelétricos da Costa Rica contratou o Centro Científico Tropical, que possuía larga experiência na elaboração de projetos ambientais e ecológicos para este tipo de empreendimento.

Os trabalhos foram dirigidos diretamente pelo Ministério de Recursos Naturais de Energia e de Minas da Costa Rica, que constituiu um grupo multidisciplinar de especialistas, contando com 15 membros nas seguintes áreas: hidrologia, biologia, vulcanologia, ecologia, vida selvagem e turismo.

Os especialistas indicaram como metodologia dos trabalhos a utilização da técnica de dupla avaliação - Matriz de Leopold - dando notas de 1 a 10 , em ordem crescente de importância dos impactos. 
O EIA determinou a viabilidade do projeto do ponto de vista ambiental e o grupo de trabalho chegou às seguintes conclusões (PERALTA, 2003):

- A hidrelétrica era viável do ponto de vista ambiental;

- Causaria forte impacto durante a fase de construção, especialmente na paisagem;

- Haveria impactos de longo prazo para os quais seria importante haver especificações claras quanto à sua mitigação e

- Alguns outros possíveis impactos foram identificados, especialmente relativos à atividade vulcânica.

E foram feitas as seguintes recomendações:

- Atenção deveria ser dada ao assentamento das tubulações, de forma a eliminar os impactos negativos em relação à paisagem;

- Gerenciamento cuidadoso das áreas de disposição de aterro;

- Preservação de vazão de água para o abastecimento das populações afetadas pelo projeto;

- Cuidados com os achados arqueológicos encontrados na fase anterior à construção;

- Realização de pesquisa para averiguar a eventual emanação de gases ácidos no lago e também nas tintas utilizadas para revestir os diferentes materiais (tubulações e turbinas);

- Acompanhamento periódico da saúde dos trabalhadores para verificar eventual aparecimento de doenças ou outros efeitos na saúde;

- Instalação de rede de sismógrafos para continuar os estudos sísmicos no reservatório;

- Instalação e manutenção da rede de monitoramento do rio para verificar o potencial de solapamento das margens; 
- Estabelecimento de sistema de medidas das vazões afluentes ao reservatório e registro fotográfico da bacia para avaliar a variação de vazão nas quedas d'água;

- Reflorestamento de todo o perímetro do reservatório;

- Limpeza de toda a área de vegetação antes do enchimento do reservatório;

- Precaução na construção do túnel de desvio do rio Agrio;

- Verificação das emissões ácidas sobre o rio e reservatório e convite ao público para visitar as quedas d'água nas turbinas e nos vertedouros;

- Manutenção da vazão de descarga de $2,0 \mathrm{~m}^{3} / \mathrm{s}$ no rio Toro e $0,4 \mathrm{~m}^{3} / \mathrm{s}$ no rio Gata, que são, respectivamente, as vazões médias mensais mínimas nestes rios, nos períodos de maior atividade turística (aos sábados e domingos);

- Desenvolvimento de um plano de educação ambiental;

- Informação à população local de eventuais transtornos;

- Promoção da preparação e da execução do plano de gerenciamento para a bacia do Alto Toro.

\subsubsection{Colômbia}

A partir do ano de 1997, a Colômbia empreendeu uma análise crítica nos procedimentos que estava utilizando para avaliações e estudos ambientais, incorporando novos elementos, tais como: estudos de risco ambiental (ERA); estudos de impactos ambientais e desenvolvimento regional (EIARD) e estudos dos impactos sociais (EIS), os quais representam elementos básicos para a elaboração da Avaliação Ambiental Estratégica (AAE). 
A Colômbia foi o primeiro país da América Latina a aplicar os conceitos ambientais nas propostas de desenvolvimento, e em 1974, editou a Lei 2811/74, denominada "Código ambiental para a proteção dos recursos naturais" (ACOSTA, 2003).

Esta lei conceituou meio ambiente como uma propriedade comum da sociedade; estabeleceu uma política ambiental; definiu a chamada "declaração de efeito ambiental" (ACOSTA, 2003). Esta Declaração estabeleceu que os empreendimentos a serem implantados deveriam ser objeto de estudos ambientais e ecológicos, que incluiriam aspectos sociais e econômicos, condição fundamental para a obtenção da licença para a implantação.

A legislação foi aprovada e quando de seu efetivo início de implantação, observaram-se alguns pontos de vulnerabilidade:

- Falta de profissionais habilitados para a aplicação desse novo campo profissional;

- O sentimento geral da sociedade que as questões ambientais não eram importantes;

- A instituição que foi designada para a aplicação da lei - a Inderena que era um braço do Ministério da Agricultura, possuía uma limitada esfera de atuação, o que levou importantes setores da economia nacional, como saúde, infra-estrutura, indústria, petroléo, mineração e urbanismo, que estavam ligados a outros importantes ministérios, freqüentemente, questionarem sua autoridade.

Em 1993, foi criado na Colômbia, o Ministério do Meio Ambiente, através de Lei específica, com o objetivo de aplicar a legislação ambiental.

A Lei estabeleceu 31 departamentos autônomos, segundo diferentes regiões geográficas, e definiu que a administração dos recursos naturais e renováveis em todo o território nacional deveria ser gerenciada por estes Departamentos.

Simultaneamente, a Lei definiu também quais os tipos de projetos que deveriam cumprir as formalidades de obtenção de licença para sua implementação. A 
solicitação de licença deveria ser feita diretamente ao Ministro ou a aqueles que tinham a responsabilidade para tal, nos Departamentos Autônomos.

Como diferentes Ministérios estavam envolvidos nos diferentes projetos, e cada um deles com sua independência para decidir sobre os EIAs, a principal tarefa do Ministério do Meio Ambiente foi a de estabelecer procedimentos, padrões, literatura e Termos de Referência - TR para alguns tipos específicos de empreendimentos.

O setor privado foi consultado para a elaboração das normas e padrões, e assim foi útil sua participação, vez que ele seria chamado a cumprir as normas que ele mesmo ajudara a elaborar.

Em curto espaço de tempo, cinco anos, a demanda para obtenção de licenças no Ministério do Meio Ambiente representou a entrega de 1536 relatórios ambientais, distribuídos nos setores mostrados na tabela 3.10.

Tabela 3.10 - Relatórios ambientais entregues ao Ministério do Meio Ambiente Colombiano nos últimos cinco anos

\begin{tabular}{l|c}
\hline Setores & Quantidade de Estudos \\
\hline Infraestrutura & 493 \\
\hline Petróleo & 753 \\
\hline Fertilizantes & 104 \\
\hline Mineração & 49 \\
\hline Sistema Elétrico & 137 \\
\hline
\end{tabular}

Fonte: ACOSTA (2003).

Iniciaram-se, também, os conflitos entre o Ministério do Meio Ambiente e os Departamentos Autônomos, especialmente no que diz respeito à qualidade dos EIAs recebidos. Havia no Ministério equipe técnica para analisar se a qualidade e a quantidade de informações dos EIAs eram suficientes, em contraste com as equipes técnicas dos Departamentos Autônomos, sempre às voltas com problemas orçamentários. 
As distorções na análise dos projetos levaram a que o processo geral de avaliação fosse questionado: quanto, quem e em que extensão as técnicas de avaliação (análise de risco, avaliação de impactos ambientais no desenvolvimento regional, avaliação dos impactos sociais e avaliação ambiental estratégica) introduzidas na gestão ambiental da Colômbia estavam sendo eficientes.

Baseado em consultoria internacional, foram escolhidas quatro áreas para revisão crítica:

- Descrição do desenvolvimento e o ponto de partida local;

- Avaliação dos impactos sociais;

- Avaliação dos riscos ambientais;

- Avaliação dos impactos ambientais no desenvolvimento regional.

Esta revisão mostrou com clareza que havia suficiente experiência e competência técnica para as questões ambientais locais, tais como: as descrições ambientais no momento do início dos projetos, tipos e quantidades de resíduos e efluentes a serem gerados e a extensão geográfica dos impactos.

Em relação aos impactos sociais, verificou-se que eles eram simplesmente descritos, sem uma análise mais profunda, e não se desenvolveu nenhum processo para se mitigá-los. Não se avançou muito neste ponto.

Quanto à análise de riscos ambientais, julgou-se que os métodos estavam adequados e cobriam as necessidades, identificando e permitindo atingir as recomendações que normalmente eram estabelecidas nessa área, que de uma maneira geral, se restringiam a um plano de gerenciamento ambiental, cujo conteúdo deveria ser apresentado ao Ministério do Meio Ambiente.

Quanto à avaliação dos impactos ambientais no desenvolvimento regional, não se elaborou nenhuma proposta conclusiva. A experiência prática tem mostrado que o EIA isoladamente não oferece condições para controle total da poluição, e é necessário um estudo aprofundado nas questões de localização das zonas industriais com racionalidade para oferecer condições efetivas de controle da 
poluição e seus eventuais efeitos cumulativos provocados pela interação entre as emissões de diversas indústrias.

A Avaliação Ambiental Estratégica mostra que estratégias e políticas são necessárias para o desenvolvimento econômico e para a proteção ambiental e que leniência política nessa área leva necessariamente às condições de insustentabilidade, gerando aumento da poluição e pressão inaceitável aos ativos ambientais.

Acosta (2003) concluiu que embora o Ministério tenha clareza quanto à necessidade, importância e urgência de se estabelecer novas formas de avaliação ambiental, não foram ainda definidas formas e métodos para tal revisão. Mas, a despeito de todas as dificuldades, o Ministério do Meio Ambiente tem conseguido importantes avanços no estabelecimento de padrões, normas e procedimentos para setores específicos e mesmo para alguns projetos, o que tem tornado o EIA instrumento fundamental de análise.

A estrutura administrativa com 30 entidades autônomas exige constantes esforços por parte do Ministério do Meio Ambiente, objetivando manter a qualidade do processo do EIA.

As análises ambientais de risco estão metodologicamente bem concatenadas com os relatórios ambientais, especialmente nos projetos maiores, com o controle direto do Ministério. É necessário que o Ministério divulgue a experiência acumulada nesta área para todas as entidades autônomas.

Será necessário um grande esforço para tornar operacionais e efetivas as análises dos impactos sociais, saindo da mera descrição da ocorrência para a quantificação dos seus efeitos e possíveis mitigações.

Por outro lado, as variáveis sociais são de grande importância nas avaliações ambientais estratégicas e de grande potencial para definição de políticas públicas, porém, necessitam de uma massa crítica maior e mais bem preparada para estabelecer as formas e normas de sua elaboração. 


\subsection{Análise Comparativa}

Sadler (1996) estabelece como condições fundamentais para a elaboração de um EIA as seguintes:

- Dispositivos legais adequados;

- Definição clara de responsabilidades;

- Escopo abrangente de análise;

- Estudo exaustivo de alternativas;

- Participação popular;

- Garantia de qualidade técnica do trabalho.

Com esses elementos, a tabela 3.11 objetiva destacar entre os diversos países analisados, algumas características relevantes de suas políticas ambientais.

Indica ainda os valores do EPI (Environmental Performance Index) - índice de performance ambiental, elaborado pela Universidade de Yale. Esse índice procura comparar 163 paises, através de 25 indicadores de desempenho, listados em dez categorias de políticas, relacionados com as condições ambientais para a saúde humana e a vitalidade dos ecossistemas. Os indicadores propiciam aos entes governamentais, uma escala comparativa, incentivando-os ao estabelecimento de metas e formulação de políticas de cunho ambiental, objetivando uma eficiente gestão nos recursos naturais (YALE, 2010). 


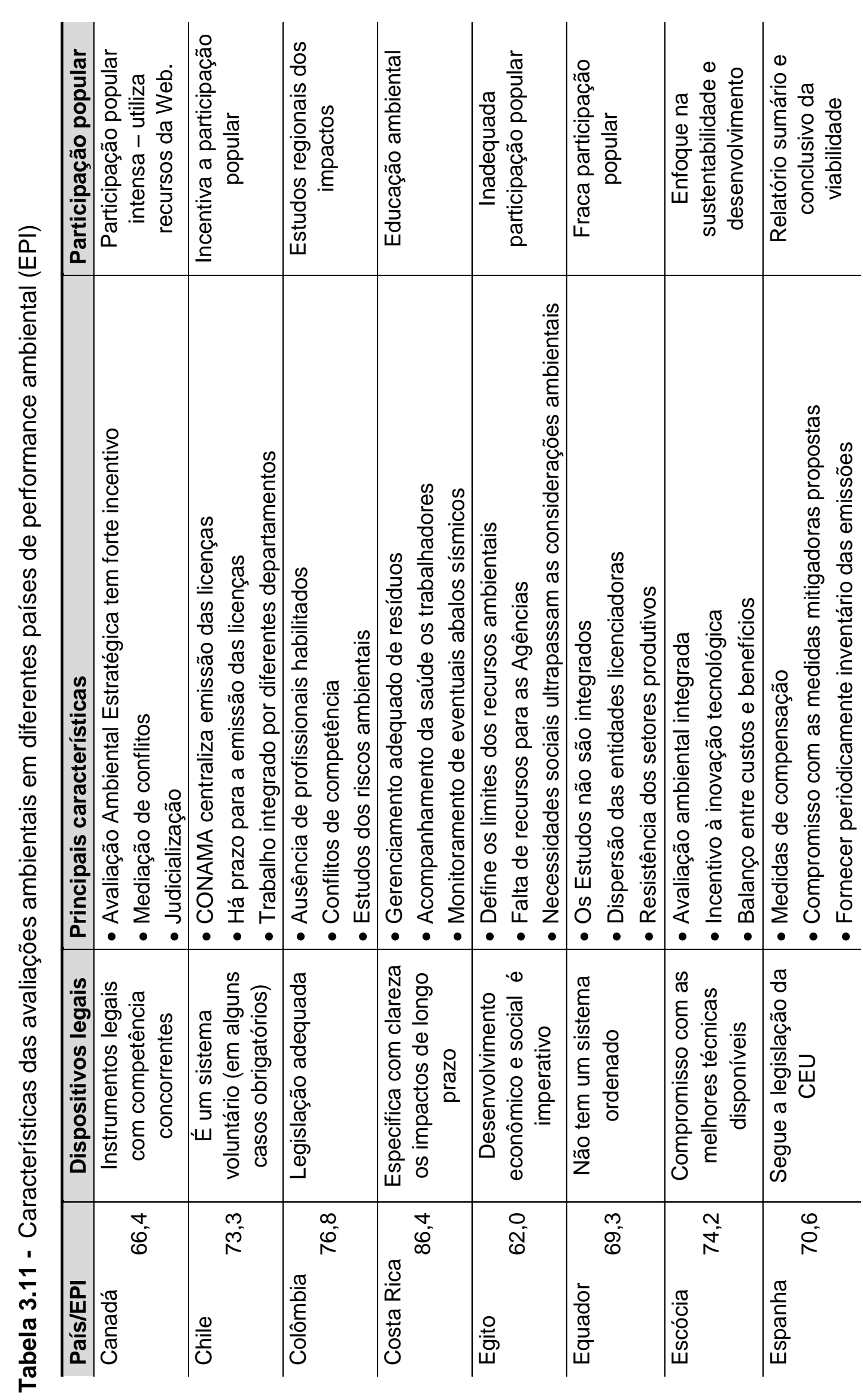




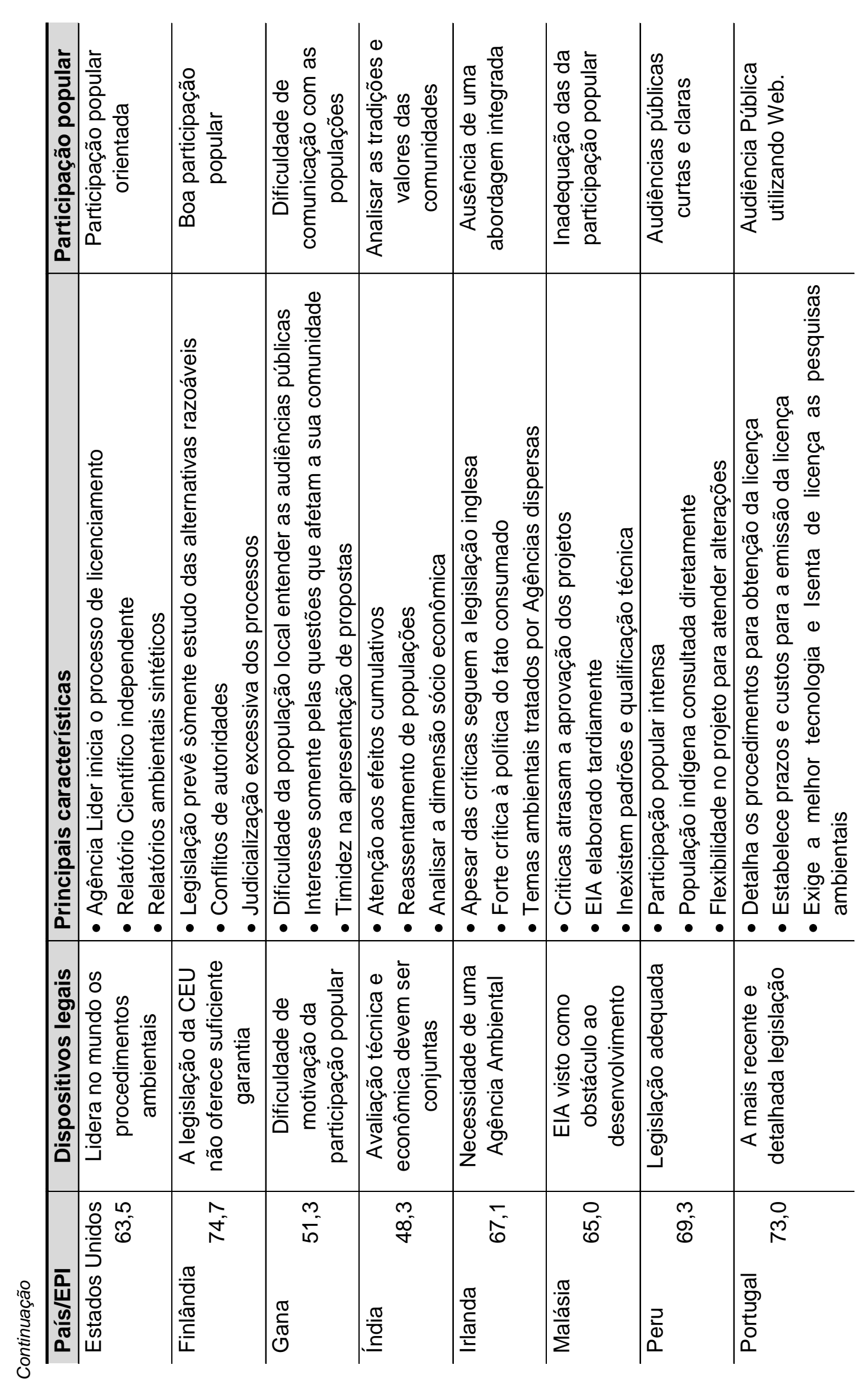




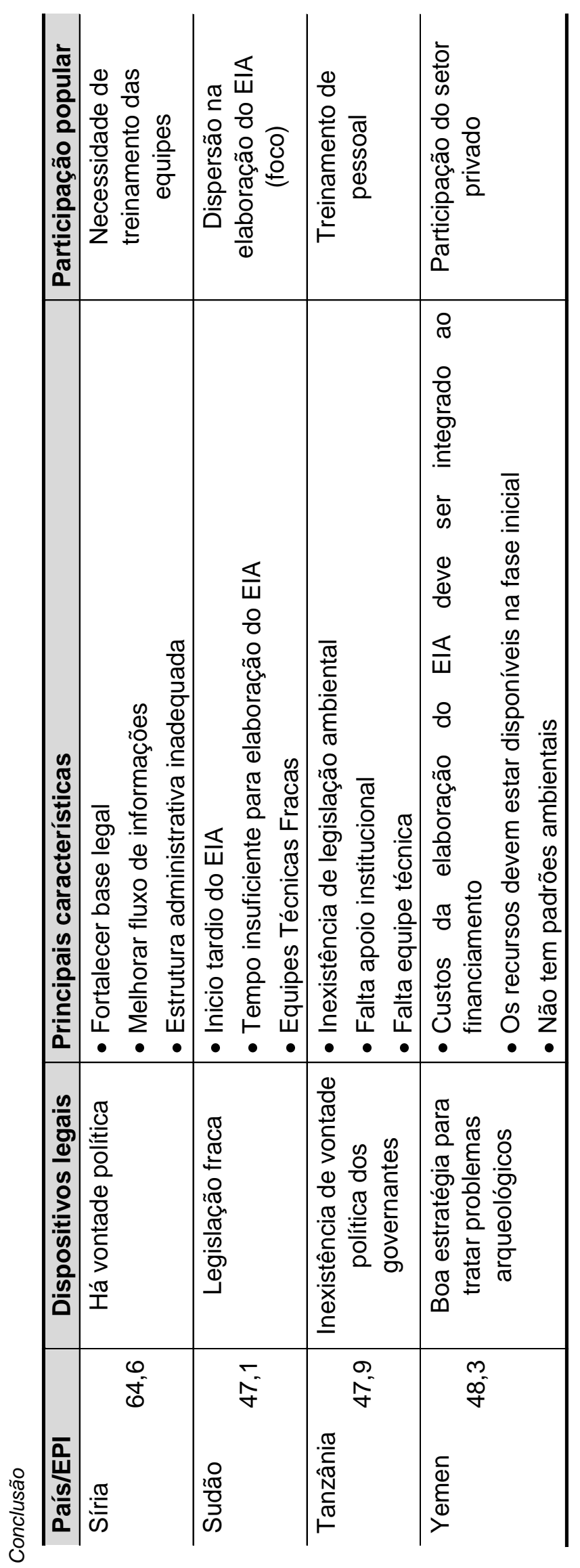




\section{METODOLOGIA}

Segundo GALLIANO (1979), o conhecimento científico "é racional, sistemático, exato e verificável da realidade. Sua origem está nos procedimentos de verificação baseados na metodologia científica".

A partir dessa definição, o autor lista os seguintes atributos para o conhecimento científico:

- É racional e objetivo;

- Atém-se aos fatos;

- Transcende aos fatos;

- É analítico;

- Requer exatidão e clareza;

- É comunicável;

- É verificável;

- Depende de investigação metódica;

- Busca e aplica as leis;

- É explicativo;

- Pode fazer predições;

- É aberto;

- É útil.

A metodologia utilizada no trabalho procurou aplicar os conceitos anteriormente descritos para atingir os objetivos de fornecer uma avaliação dos processos dos licenciamentos ambientais, fazendo um estudo comparativo com outros países, que permitiu analisar criticamente as vantagens e desvantagens dos sistemas vigentes no Brasil e em particular no Estado de São Paulo. 
O crescente problema da judicialização das questões ambientais foi abordado através de informações e entrevistas pessoais e visitas às bibliotecas das Agências Ambientais, do Ministério Público Estadual e Federal, bem como dos Tribunais de Justiça do Estado de São Paulo e do Tribunal Regional Federal da 3a Região, que jurisdiciona os Estados de São Paulo e Mato Grosso do Sul.

Fizeram parte do trabalho consultas a sites de entidades ambientais nacionais e internacionais, procurando obter informações que possibilitassem verificar o nível de transparência da disponibilidade das informações sobre os licenciamentos ambientais nos seus diversos tipos e níveis.

A análise dos documentos que compõem o licenciamento ambiental compreendeu a consulta a diversas licenças ambientais em bibliotecas.

Foram realizadas consultas a diversas entidades como Associação Brasileira de Infra-estrutura e Indústria de Base (ABDIB), Federação das Indústrias do Estado de São Paulo (FIESP), Confederação Nacional das Indústrias (CNI), ONGs Ambientalistas, todas interessadas no tema dos licenciamentos ambientais, com as suas diferentes visões e objetivos.

Para realizar o diagnóstico do sistema ambiental do Estado de São Paulo, foram coletados dados e informações junto aos entes Governamentais com tal responsabilidade, como: Secretarias do Meio Ambiente, Agências Ambientais de diversos Estados, e particularmente no Estado de São Paulo.

Foram coletados os seguintes dados e informações, de tal forma que se pudesse fazer uma avaliação do sistema e oferecer alternativas de solução:

\section{A. Recursos humanos existentes}

- Número e qualificação dos técnicos envolvidos no processo de licenciamento;

- Salário e existência de plano de carreira;

- Relação técnicos/funcionários administrativos; 
B. Infra-estrutura existente

- Número de veículos por técnico;

- Informática;

- Equipamentos de campo;

- Laboratórios.

C. Aspectos institucionais

- Articulação com outros órgãos;

- Compatibilidade de atribuições.

D. Tempos para concessão das licenças

- Prazo de análise dos processos;

- Causas da demora na avaliação.

E. Licenças

- Número de solicitações por porte de empreendimentos;

- Número de licenças concedidas.

F. Participação pública

- Número de pessoas da comunidade presentes nas audiências públicas;

- Número de ONGs presentes nas audiências públicas.

G. Orçamento

H. Acompanhamento pós-licença 


\section{ANÁLISE CRÍTICA DOS SISTEMAS DE AVALIAÇÃO AMBIENTAL}

Uma gestão adequada e responsável do meio ambiente e dos recursos naturais é importante em todos os países e, em particular, naqueles com menor grau de desenvolvimento como o Brasil. É nesses países que se concentram os maiores ativos ambientais, mas também as maiores desigualdades sociais.

As populações mais pobres anseiam pela transformação de suas condições de vida através do desenvolvimento. A correta gestão ambiental e dos recursos naturais propicia a essas populações melhores condições de saúde, reduz sua vulnerabilidade a desastres naturais e aumenta as oportunidades de bem estar, como indica os dados da UNDP (2004): entre 1980 e 2000, mais de 1,5 milhões de pessoas morreram em enchentes, erupções vulcânicas, tempestades tropicais, escorregamentos de taludes, secas e outros desastres naturais.

Mortes e perdas econômicas causadas por desastres naturais são de longe mais graves em países pobres do que em países ricos. A alta vulnerabilidade ambiental desses países está diretamente relacionada com a inexistência de planos adequados de contingência para dar pronta resposta, assim como a inadequada integração entre as variáveis ambientais e os planos regionais de desenvolvimento urbano.

Políticas públicas que levem em conta as existentes e futuras variáveis ambientais e o uso dos recursos naturais são as maneiras adequadas de se tratar a questão.

É imperativo que os formuladores de políticas e o próprio público tenham em mente as oportunidades e os custos necessários para se promover o bem estar das populações. E eles devem estar alinhados com as necessidades de promover 0 desenvolvimento econômico e a sustentabilidade ambiental, o que implica entender as diferentes perspectivas da questão ambiental. 


\subsection{A Perspectiva da Economia}

Grande parte dos problemas ambientais está relacionada com o crescimento da atividade econômica em escala global.

O crescimento das trocas comerciais em escala internacional e as pressões induzindo ao consumo têm sido importantes fatores das alterações das condições ambientais.

Pode-se afirmar que as ligações entre a produção e meio ambiente são múltiplas, complexas e importantes.

A liberalização comercial por si só não é necessariamente boa ou má para o meio ambiente. Seus efeitos nos ecossistemas dependem da extensão em que o meio ambiente $e$ as linhas de produção tenham metas complementares e que se equilibrem mutuamente. Uma produção ambientalmente adequada requer mercados maduros em nível nacional e internacional para entender seus limites e possibilidades.

Na sua expressão mais simples, o meio ambiente e a produção estão relacionados porque a atividade econômica é dependente dos ativos ambientais, que é a fonte dos insumos de produção, tais como metais, minerais, solo, florestas e pesca, e de energia, que processa a todos os insumos.

É o meio ambiente também que recebe todos os resíduos da atividade econômica, que por sua vez, deve dar-lhes destinação adequada e compatível com a capacidade de suporte do meio.

Nos dias atuais, cresce também uma forte preocupação concernente às barreiras não tarifárias, que ora valoriza ou não os produtos e serviços elaborados com responsabilidade ambiental.

Se por um lado as relações comerciais internacionais estão centradas num organismo das Nações Unidas, a Organização Mundial do Comércio, que organiza as relações legais entre os participantes, as relações concernentes ao meio 
ambiente estão dispersas em vários acordos multilaterais, nacionais e subnacionais, que procuram regular as diversas relações.

É absolutamente necessário que os dois sistemas legais se compatibilizem para oferecer segurança jurídica aos empreendedores e proteção legal e efetiva ao meio ambiente, nas suas respectivas visões, tanto no nível internacional quanto no nacional, e que devem ser analisados através das diferentes perspectivas da produção, do meio ambiente e do desenvolvimento.

Estas perspectivas não são mutuamente excludentes e tanto melhor será para a sociedade se ela puder se apropriar das três.

\subsection{A Perspectiva da Produção}

A produção cria riquezas, que podem ser usadas para aumentar o bem estar da sociedade. Tentando atingir esse objetivo, muitos governos nacionais acionam diretamente as indústrias locais e procuram preservar os mercados domésticos para estas indústrias, excluindo as estrangeiras.

Ao proceder assim, tais governos prestam um mau serviço aos seus cidadãos, incentivando ineficiências e preços mais altos aos consumidores internos. Empresas estrangeiras com processos mais eficientes são excluídas do comércio nacional.

A melhor proteção seria um forte sistema de regras contra tais atitudes, tais como as preconizadas pela Organização Mundial de Comércio, que todos os países deveriam obedecer.

Mesmo após assinar os acordos, alguns países sofrem pressões políticas para não seguir os tratados; as barreiras não alfandegárias de cunho ambiental são um bom exemplo.

O mercado é realmente bom para o meio ambiente já que ele cria riqueza que pode ser usada para incrementar a proteção ambiental. Maior eficiência implica em usar 
menos recursos naturais e gerar menos resíduos, uma vez que usam tecnologias mais amigáveis em relação ao meio ambiente.

\subsection{A Perspectiva do Meio Ambiente}

Os atuais sistemas sociais e econômicos assim como os preços dos bens e serviços não refletem os custos dos danos e da recuperação ambiental incorridos para produzi-los e estão seriamente ameaçando os ecossistemas terrestres.

Muitos governos se reportam diretamente às indústrias nacionais e vão tentar protegê-las contra os custos das demandas ambientais. Ao proceder assim, os governos prejudicam seus cidadãos: empresas locais lucram, mas o público subsidia tais empresas, pagando os custos da degradação ambiental.

A forma de evitar esses problemas é um forte sistema de regulação, explicitando com clareza como o meio ambiente deve ser protegido em nível nacional ou internacional.

Mesmo após tais regramentos entrarem em vigor, os governos e a indústria irão, passo a passo, procurar meios de escapar delas. É nesse contexto que certos tipos de barreiras ambientais não alfandegárias representam um caminho que ajuda a impor restrições utilizando aparentes requisitos ambientais.

Mais produção e comércio significam mais atividades econômicas e, portanto, em alguns casos, mais danos ambientais. A riqueza criada pela atividade econômica não necessariamente resulta em benefícios ambientais.

\subsection{A Perspectiva do Desenvolvimento}

Mais da metade da população vive na mais absoluta pobreza, a maioria em países de baixo desenvolvimento, e o fosso entre os países ricos e pobres continua a 
aumentar. Países em desenvolvimento têm como sua principal prioridade reduzir a pobreza e diminuir o tamanho desse fosso.

A abertura comercial e industrial pode ser a chave para realizar tal desejo, mas a relação entre abertura econômica e crescimento não é automática.

Os países ricos protegem seus agentes econômicos através de subsídios, regras especiais de comércio e de incentivos tarifários, que prejudicam os produtores e exportadores dos países em desenvolvimento.

A solução para se evitar tais atitudes é desenvolver um forte conjunto de regras contra tais processos, mas no momento atual, as regras da Organização Internacional de Comércio são fortemente influenciadas pelo poder econômico das nações desenvolvidas e uma liberalização em alguns setores específicos tem favorecido muito o interesse dos países desenvolvidos.

Nos últimos tempos, muitas dessas atitudes têm passado ao largo da lei, e os países ricos estão procurando novos caminhos para colocar a concorrência fora de seus mercados. Banir ou restringir o comércio utilizando questões ambientais pode ser um desses caminhos tortuosos e tem sido usado com relativa freqüência.

Exigir que países pobres cumpram padrões ambientais de países ricos não é razoável, especialmente se essa exigência não for precedida de assistência técnica ou financeira. As prioridades são diferentes: por exemplo, em muitos países pobres, água potável é um desejo, enquanto que nos países desenvolvidos, é uma premissa básica. E, quando se pensa em problemas globais, tais como a depleção da camada de ozônio e mudanças climáticas, os países ricos causam mais danos ambientais num primeiro momento.

Ao longo dos anos, os debates entre comércio e meio ambiente têm se alargado para incluir as preocupações descritas anteriormente, pela simples razão de que se percebe que as soluções dos problemas ambientais não serão factíveis se pensadas isoladamente.

Assim, a solução que melhor se adapta é um longo caminho de cooperação, objetivando eliminar as barreiras, que impedem as empresas e os países menos 
desenvolvidos de atingir os padrões dos mais desenvolvidos, e ao mesmo tempo, proteger o meio ambiente, preservando-o para as futuras gerações. É o desenvolvimento sustentável.

Para que tais anseios sejam atendidos, os países estabeleceram instrumentos institucionais para acompanhamento e monitoramento das políticas, dos planos e dos programas, levando em consideração as variáveis ambientais no momento de sua elaboração, implementação e execução, tais como os Estudos Ambientais em suas diferentes formas: Avaliação Ambiental Estratégica e Avaliação dos Impactos Ambientais.

\subsection{Avaliação Ambiental Estratégica}

A avaliação dos impactos ambientais aplicada aos projetos teve seu início na década de 1970 (SADLER, 1996); sua extensão e aplicação dos conceitos e métodos, com a devida adaptação às políticas, programas e planos constituem a Avaliação Ambiental Estratégica (AAE).

O objetivo principal da AAE é o de incorporar a variável ambiental já nos primórdios das formulações das políticas, planos e programas, o que tornaria mais célere o processo de AIA nos projetos específicos. Alguns países, tais como a União Européia impõem em sua legislação que seja feita a Avaliação Estratégica dos Impactos na fase de formulação de planos e programas, outros, como a China, a exigem já na fase de formulação de políticas (WORLD BANK, 2008).

O pretendido com tal abordagem é que não haja descontinuidade entre a elaboração dos planos e programas e a efetiva implantação dos projetos deles decorrentes no que concerne às variáveis ambientais.

A AAE objetiva incluir as variáveis ambientais na esfera mais alta de decisão política, e para tanto, usa uma variedade de abordagens e análises, ao invés de uma simples avaliação das possíveis conseqüências. Quando a AAE centra seu foco na avaliação dos impactos ambientais, ela passa a ser um processo sistemático de avaliação das conseqüências ambientais de uma determinada proposta política, 
plano ou programa, analisados já na fase preliminar, levando em consideração as variáveis ambientais em conjunto com as considerações econômicas e sociais (WORLD BANK, 2008).

A AAE é, pois, um instrumento de integração entre meio ambiente e sustentabilidade nos altos escalões administrativos, e será tanto mais eficazmente utilizada quanto mais possibilitar que as Avaliações dos Impactos Ambientais sejam antecipadas na aplicação dos projetos futuros.

\subsection{As Avaliações dos Impactos Ambientais - AlAs}

A Avaliação dos Impactos ambientais tem sido descrita como a inovação política de maior sucesso no século 20.

Trinta anos atrás, ela não existia e hoje é adotada por mais de 100 países, objetivando fornecer aos formuladores da decisão política, um instrumento efetivo para se avaliar as conseqüências ambientais de um determinado plano ou ação.

No século 21, haverá necessidade de aperfeiçoamentos na forma de aplicação desse instrumento, para responder de maneira eficaz às novas demandas de uma economia de grande dinamismo.

Com essa perspectiva de futuro, Sadler (1996) sugere quatro campos para aperfeiçoamentos:

- Estabelecer o foco das AIAs em padrões e princípios;

- Focar na aplicação dos conceitos de sustentabilidade, avaliação ambiental estratégica e os efeitos cumulativos de larga escala;

- Fortalecimento do processo, centrando nas relações da AIA com as tomadas de decisão;

- Capacidade de empreender. Este é um tema particularmente necessário para os países em desenvolvimento. 
Esses aperfeiçoamentos serão efetivos na medida em que for elaborada uma análise crítica das condições de sua aplicação, comparando-os com as experiências internacionais existentes. Para tanto, deverão ser utilizados os seguintes princípios práticos:

- Iniciar as AIAs tão cedo quanto possível, de forma a tornar factível eventuais revisões para a melhor escolha das alternativas;

- Termos de referências claros e objetivos, abarcando os problemas prioritários, prazos para execução dos trabalhos e aberturas para as contribuições nos momentos chave de decisão;

- Informações e estudos de qualidade suportados por especificações consistentes, oferecendo oportunidade para a utilização das melhores tecnologias;

- Comprometimento dos tomadores de decisão e dos empreendedores, embasados em boa comunicação e coleta de dados.

Como resultado dessas práticas, já se pode verificar o surgimento de uma "indústria verde" com grandes oportunidades de negócios.

A Tabela 5.1, a seguir, relaciona as características que devem ter as AIAs, segundo as boas práticas internacionais. 
Tabela 5.1 - Boas práticas na elaboração da AIA

\begin{tabular}{|c|c|}
\hline Características da AIA & Como Fazer \\
\hline Propositiva & $\begin{array}{l}\text { - Concentrar-se nos objetivos de informar as esferas de } \\
\text { decisão, assegurando um apropriado nível de proteção } \\
\text { ambiental e à saúde humana. }\end{array}$ \\
\hline Focada & $\begin{array}{l}\text { - Deve concentrar-se nos efeitos mais significativos, tendo } \\
\text { em vista os problemas que podem causar }\end{array}$ \\
\hline Adaptável & $\begin{array}{l}\text { - Deve-se ajustar às realidades e problemas e } \\
\text { circunstâncias locais }\end{array}$ \\
\hline Participativa & $\begin{array}{l}\text { - Prover apropriadas oportunidades para informar e } \\
\text { envolver os interessados; a população afetada e suas } \\
\text { propostas devem ser avaliadas criteriosamente }\end{array}$ \\
\hline Transparência & $\begin{array}{l}\text { - Deve ser claro, fácil de ser entendido e um processo } \\
\text { aberto, com acesso e prévia informação ao público } \\
\text { interessado }\end{array}$ \\
\hline Rigor técnico & $\begin{array}{l}\text { - Ser elaborado com profundidade técnica, avaliando os } \\
\text { impactos e problemas que estão sendo investigados }\end{array}$ \\
\hline Prático & $\begin{array}{l}\text { - Identificar os processos para mitigação dos impactos e a } \\
\text { forma de implementá-los }\end{array}$ \\
\hline Confiável & $\begin{array}{l}\text { - Ser elaborado com profissionalismo, rigor, correção, } \\
\text { objetividade, imparcialidade e equilíbrio. }\end{array}$ \\
\hline Eficiente & $\begin{array}{l}\text { - Entre seus objetivos e propósitos, a AIA deve representar } \\
\text { um custo mínimo aos proponentes. }\end{array}$ \\
\hline
\end{tabular}

Fonte: Adaptado de Sadler (1996) e IAIA (1999)

\subsubsection{Benefícios e custos}

Os benefícios que a AIA agrega à análise ambiental podem ser diretos, tais como utilização das melhores tecnologias disponíveis nos projetos, ou indiretos, como melhorar a qualidade na elaboração dos trabalhos da AIA e aumentar o conhecimento das questões ambientais para os técnicos envolvidos.

De forma geral, os benefícios incluem: 
- Melhor planejamento e projetos mais adequados ambientalmente;

- Maior segurança e comprometimento na utilização dos padrões ambientais;

- Economia de recursos no investimento e na futura operação;

- Redução nos tempos e custos da aprovação dos projetos;

- Melhor aceitação da opinião pública aos projetos.

Em algumas ocasiões, os agentes atribuem às AlAs as causas dos excessivos tempos e atrasos para aprovação e implementação dos projetos. Muitos desses problemas são causados por inadequada administração dos mesmos, bem como da excessiva burocratização. Esses fatos normalmente ocorrem quando:

- A AIA se inicia tardiamente no ciclo do projeto;

- Os termos de referência são elaborados com falhas;

- Não são definidos prazos para a execução dos trabalhos;

- As equipes técnicas não têm preparo suficiente;

- Os estudos ambientais conseqüentes são incompletos e deficientes para a tomada de decisão.

A definição do custo é uma tarefa bastante imprecisa, uma vez que depende muito da especificidade de cada projeto; alguns requerem um grande número de investigações técnicas; outros mais simples exigem avaliações mais expeditas; alguns necessitam de complexos estudos de viabilidade, análise de riscos, análises hidrológicas de longo prazo e complexos estudos dos solos locais.

Mesmo assim, as Agências Internacionais de Financiamento, como o Banco Mundial e o Banco Interamericano de Desenvolvimento, indicam que o custo desses estudos raramente ultrapassa um por cento do custo total do empreendimento e pode ser bastante reduzido se as equipes técnicas locais tiverem capacitação para desenvolvê-los. 
Para o Banco Mundial, os custos relativos para o desenvolvimento de uma AIA, de uma maneira geral, variam entre 0,06 a 0,10 por cento do custo total do projeto, respectivamente, para pequenos e para grandes projetos (SADLER, 2002).

De forma semelhante, os tempos necessários para o desenvolvimento dos estudos variam desde poucas semanas para um pequeno projeto de irrigação até um ou dois anos para grandes projetos de barragens ou para obras de infra-estrutura.

Geralmente, os custos e tempos envolvidos nos processos diminuem à medida que as equipes ganham experiência e mais segurança na definição dos impactos associados nos diferentes tipos de projetos. É pois necessário incentivar o estudo e aplicação dessa técnica pelas equipes, de tal forma que os ganhos de eficiência venham a diminuir os custos e prazos, ao mesmo tempo em que se aumentam os benefícios para o meio ambiente.

Com esses objetivos, alguns pontos podem ser considerados:

- Formação de equipe de consultores com vistas a que tenham competência na administração das Agências Ambientais;

- Ampla publicidade aos Relatórios de Impactos Ambientais;

- Dar publicidade às razões da decisão, alternativas estudadas e a opção escolhida ao final, e igualmente para as medidas mitigadoras, e os planos para acompanhamento.

\subsubsection{Impacto Ambiental Significativo}

A Constituição Brasileira em seu Artigo 225 estabelece:

"Art. 225. Todos têm direito ao meio ambiente ecologicamente equilibrado, bem de uso comum do povo e essencial à sadia qualidade de vida, impondo-se ao poder público e à coletividade o dever de defendê-lo e preservá-lo para as presentes e futuras gerações. 
\$1ำ Para assegurar a efetividade desse direito, incumbe ao poder público...

IV. Exigir, na forma da lei, para a instalação de obra ou atividade potencialmente causadora de significativa degradação ao meio ambiente, estudo prévio de impacto ambiental, a que se dará publicidade."

A discussão que se estabelece na aplicação prática desse mandamento constitucional está na correta interpretação do significado da expressão "potencialmente causadora de significativa degradação", para exigir a elaboração do EIA-RIMA.

A exigência do EIA/RIMA foi estabelecida inicialmente na Resolução CONAMA $n^{\circ}$. 01/86, que em seu artigo $2^{\circ}$, apresenta as modalidades de empreendimentos, cujos impactos deveriam ser estudados através dos referidos instrumentos. A Constituição de 1988 trouxe exigência semelhante, mas apenas para os casos de obras e atividades potencialmente causadoras de significativa degradação do meio ambiente (CAVALCANTI, 2010)

A resolução CONAMA 237/97, no seu parágrafo único do artigo 3ํㅡㄹ estabelece que o órgão ambiental, verificando o potencial grau de poluição do empreendimento, definirá o nível de estudos ambientais necessários para o licenciamento.

É nesse contexto que a importância da elaboração das AIAs se manifesta através do desdobramento das suas diferentes fases, sendo a primeira delas a seletividade.

\subsubsection{Seletividade (Screening)}

O processo para se determinar se um projeto estará sujeito a uma avaliação do impacto ambiental (AIA) é chamado de seletividade (screening), existindo várias formas de aplicação (WOOD, 1995).

O objetivo da seleção de ações é identificar somente as que geram impactos significativos sobre o meio ambiente e submetê-las a AIA, descartando as demais. 
Existem várias formas para a determinação de quão significativo é o impacto nos sistemas de avaliação (UNEP, 1996a):

- Listagem classificatória das ações, projetos ou tipos de obras (Europa);

- Estudo preliminar ou aplicação de critérios que determinam os aspectos adversos de relevância (EUA);

- Procedimentos e métodos desenvolvidos por países ou agências de financiamento (Agências de Cooperação);

- Histórico de projetos e revisões já desenvolvidos anteriormente para atividades semelhantes.

O conceito de impacto significativo tem causado grande controvérsia na maioria dos sistemas de avaliação de impactos ambientais ao redor do mundo. No caso específico, os Estados Unidos tem procurado estabelecer critérios qualitativos e quantitativos para discriminar a significância de uma ação ambiental (WOOD, 1995).

Por sua vez, a Europa define os tipos de projetos que consideram plausíveis de causar impactos significativos sobre o meio ambiente, e estabelece uma lista, que é complementada por alguns critérios, tais como a natureza do projeto, o porte e a sua localização. A estes se aplica, então, a Avaliação dos Impactos Ambientais de forma obrigatória.

Outra forma de seletividade é a atuação discricionária da autoridade ambiental, que analisando os antecedentes do projeto e as informações disponíveis, decide se ele deve ou não se submeter a uma AIA. Este é o modelo Australiano (WOOD, 1995).

De uma forma geral, a maioria dos sistemas de avaliação dos impactos ambientais adota uma forma híbrida, isto é, há uma listagem prévia das atividades que devem se submeter à avaliação - um conjunto típico de projetos e atividades impactantes e também a discricionariedade por parte das autoridades é utilizada e, muitas vezes, instigada pela participação popular. Esta forma de trabalho é chamada de sistema misto (WOOD, 1995). 


\subsubsection{Aprofundamento (Scoping)}

O processo que define a profundidade da análise que deverá fazer parte da Avaliação do Impacto Ambiental no documento dos Estudos de Impactos Ambientais é denominado aprofundamento (scoping), e no Brasil, muitas vezes, Termo de Referência (TR).

Ele tem como objetivo principal a especificação dos termos da avaliação ambiental, ou seja, do tipo de avaliação ambiental que irá desenvolver (WOOD, 2000).

O objetivo central desse processo é assegurar que a avaliação esteja orientada para os aspectos mais relevantes do projeto e especialmente naqueles que possam gerar impactos adversos significativos.

O processo se originou na década de 1970, quando diversos e volumosos documentos de AIA eram elaborados e se prendiam a aspectos pouco relevantes para a avaliação (WOOD, 1995).

Assim, originaram-se algumas tentativas de simplificação, procurando concentrar mais no rigor das avaliações, tais como:

- Lista dos critérios que permitam definir os aspectos mais relevantes;

- Documentos de avaliação preliminar dos impactos ambientais.

E, por outro lado, foram estabelecidos diversos métodos para se identificar os impactos ambientais mais relevantes: listas dos impactos, matrizes, diagramas de fluxo, entre outros.

Em todos eles, a condição preliminar é a participação popular e a dos grupos de interesse. De pronto surgiram questões para verificar se o processo se tornou ou não mais profundo e significativo com a participação popular (WOOD, 1995).

É nesse contexto que se procurou definir os conteúdos gerais que devem ser contemplados nos documentos que avaliam os impactos ambientais - Tabela 5.2 (UNEP, 1996a). 
Tabela 5.2 - Conteúdos dos estudos de impactos ambientais

\begin{tabular}{|c|c|}
\hline Conteúdo & Descrição \\
\hline Introdução & $\begin{array}{l}\text { - Introduz o projeto e apresenta os aspectos ambientais } \\
\text { mais críticos que estão envolvidos }\end{array}$ \\
\hline Contexto do Projeto & $\begin{array}{l}\text { - Definição do Problema: resume os inconvenientes ou } \\
\text { dificuldades que serão abordados através do projeto. } \\
\text { - Solução Proposta: resume as formas em que se propõe } \\
\text { resolver os problemas } \\
\text { - Objetivos da Avaliação: define claramente os objetivos } \\
\text { da avaliação e a relação dos resultados que serão } \\
\text { obtidos com o projeto. }\end{array}$ \\
\hline Institucionalização & $\begin{array}{l}\text { - Leis e Políticas: indicam os instrumentos legais e } \\
\text { políticos e de procedimentos que permitem executar } \\
\text { uma avaliação dos impactos. }\end{array}$ \\
\hline Análises das Alternativas & $\begin{array}{l}\text { - Alternativas ao Projeto: analisa o potencial de frustração } \\
\text { dos objetivos de desenvolvimento e avalia o potencial } \\
\text { negativo de outras opções comparando-o com a opção } \\
\text { escolhida. } \\
\text { - Alternativas de Ações do Projeto: avalia as potenciais } \\
\text { ações alternativas que foram utilizadas na proposta } \\
\text { selecionada. }\end{array}$ \\
\hline $\begin{array}{l}\text { Participação Pública e } \\
\text { Instituições }\end{array}$ & $\begin{array}{l}\text { - Instituições: mostra claramente como as instituições } \\
\text { locais e regionais ou mesmo nacionais irão participar ou } \\
\text { serão consultadas sobre o projeto. } \\
\text { - Pública: indica como os grupos afetados na região do } \\
\text { projeto terão oportunidade de participar do processo de } \\
\text { avaliação, e como as informações trazidas ao projeto } \\
\text { serão usadas na elaboração final. }\end{array}$ \\
\hline Divulgação do Projeto & $\begin{array}{l}\text { - Descrição do projeto: descreve os componentes } \\
\text { principais (localização, vida útil, tamanho, capacidade, } \\
\text { principais atividades), fontes das matérias-primas, } \\
\text { emissões, efluentes sólidos, líquidos e gasosos. } \\
\text { - Descrição ambiental: identifica os limites da avaliação } \\
\text { ambiental, o que permitirá a obtenção de dados, e os } \\
\text { limites de utilização dos ativos ambientais (água, solo, } \\
\text { ar, biota, culturais e sociais) } \\
\text { - Qualidade da informação: avalia a qualidade de toda a } \\
\text { informação apresentada, sinalizando as limitações e } \\
\text { deficiências, fontes de obtenção, mecanismos de } \\
\text { validação dos dados necessários que serão utilizados } \\
\text { nas análises dos impactos. }\end{array}$ \\
\hline
\end{tabular}


Continuação

\begin{tabular}{|c|c|}
\hline Conteúdo & Descrição \\
\hline Análise dos Impactos & $\begin{array}{l}\text { - Positivos: deverão ser previstas as causas dos impactos } \\
\text { positivos, como ocorrem e em que grandeza e } \\
\text { intensidade afetarão a qualidade ambiental da área de } \\
\text { influência como resultado da implantação do projeto, } \\
\text { comparando-o com a não existência do projeto. } \\
\text { - Negativos: deverão ser previstas as causas dos } \\
\text { impactos negativos, como eles ocorrem, e em que } \\
\text { grandeza e intensidade afetarão a qualidade ambiental } \\
\text { por sua implementação, classificando aqueles que } \\
\text { afetam os recursos naturais, humanos, } \\
\text { reassentamentos de populações, impactos cumulativos, } \\
\text { transfronteiriços se houver, e os mais significativos em } \\
\text { relação à situação atual. }\end{array}$ \\
\hline Mitigação e Monitoramento & $\begin{array}{l}\text { - Plano de gestão ambiental: desenvolver um plano } \\
\text { detalhado das medidas de mitigação que serão } \\
\text { adotadas para minimizar os impactos negativos } \\
\text { previstos, procurando evitar alguma ação de grande } \\
\text { impacto, restabelecendo as condições originais, } \\
\text { reduzindo as causas dos impactos e/ou compensando } \\
\text { os danos causados. Deve definir os responsáveis pela } \\
\text { execução do plano. } \\
\text { - Na elaboração das medidas de mitigação, devem ser } \\
\text { definidos os objetivos pelos quais estão sendo } \\
\text { formuladas, os indicadores de desempenho, a entidade } \\
\text { responsável pela implementação, o lugar onde serão } \\
\text { implementadas e os prazos. }\end{array}$ \\
\hline Conclusões e Recomendações & $\begin{array}{l}\text { - Decisões sobre o projeto: mostra como o projeto foi } \\
\text { modificado para a obtenção de melhor e maior } \\
\text { sustentabilidade. } \\
\text { - Desenvolvimento Técnico: resume as alterações no } \\
\text { projeto e na operação que foram considerados críticos } \\
\text { para melhorar a aceitação ambiental do projeto. } \\
\text { - Resumo Técnico: relata em termos não técnicos os } \\
\text { pontos-chave da avaliação, incluindo a análise } \\
\text { econômica, os aspectos ambientais mais significativos e } \\
\text { as medidas de mitigação propostas. }\end{array}$ \\
\hline
\end{tabular}

Fonte: UNEP (1996a)

As responsabilidades de preparação do documento ambiental variam no espectro conforme os atores envolvidos: 
- Os consultores são responsáveis completa ou parcialmente pela elaboração dos documentos técnicos;

- O líder do projeto é o responsável pelo fornecimento das informações sobre o projeto;

- A autoridade ambiental é responsável pela transparência do projeto e por fazer cumprir as leis e regulamentos;

- Os cidadãos emitem comentários e críticas sobre o projeto através dos canais abertos para tal.

\subsection{Aspectos comparativos entre AAE e AIA}

Os instrumentos AAE e AIA têm sido considerados eficazes para prever os impactos ambientais, assim como oferecer aos formuladores das políticas públicas, elementos para uma visão holística e transversal da utilização dos ativos ambientais. A Tabela 5.3 identifica as diferenças fundamentais entre AAE e AIA.

Tabela 5.3 - Diferenças Fundamentais entre AAE e AIA

\begin{tabular}{c|c}
\hline AAE & AIA \\
\hline Estratégia de longo prazo & Perspectiva de execução de curto e médio \\
prazos
\end{tabular}

Fonte: PARTIDARIO (2007) 
Tanto mais importantes serão esses instrumentos na medida em que os atores institucionais envolvidos os utilizem com a antecedência e a transparência devidas, objetivando as ações de licenciamento ambiental dos empreendimentos.

Certamente, as críticas formuladas quanto aos prazos para as licenças ambientais, resultados do desenvolvimento dos projetos relativos aos planos e programas, serão reduzidas na medida em que tais instrumentos sejam utilizados pelos agentes institucionais.

\subsection{Impactos Ambientais - Licenciamento}

No Brasil, a Política Nacional do Meio Ambiente foi estabelecida pela Lei $n^{0} 6938 / 81$, que definiu entre outros instrumentos, o impacto ambiental e o licenciamento das atividades efetiva ou potencialmente poluidoras.

Por essa lei, no seu artigo $3^{\circ}$, atividade poluidora é conceituada como aquela causadora da degradação da qualidade ambiental e que possa vir a resultar em prejuízos à saúde, ao bem estar das populações, às atividades sociais e econômicas, à biota, às condições estéticas e sanitárias do meio ambiente e também ao lançamento de matérias ou energia em desacordo com os padrões ambientais estabelecidos.

Edis Milaré (2004) conceitua avaliação de impacto ambiental como:

Instrumento de política ambiental, formado por um conjunto de procedimentos, capaz de assegurar, desde o início do processo, que se faça um exame sistemático dos impactos ambientais de uma ação proposta (projeto, programa, plano ou política) e de suas alternativas, e que os resultados sejam apresentados de forma adequada ao público e aos responsáveis pela tomada de decisão, e por eles considerados. Além disso, os procedimentos devem garantir a adoção das medidas de proteção do meio ambiente determinadas, no caso de decisão sobre a implantação do projeto.

No Brasil, a primeira regulamentação da Avaliação de Impacto Ambiental foi elaborada pela resolução CONAMA nำ1/86 que assim redigiu: 
Art. 1ํ Para efeito desta Resolução, considera-se impacto ambiental qualquer alteração das propriedades físicas, químicas e biológicas do meio ambiente, causada por qualquer forma de matéria ou energia resultante das atividades humanas que, direta ou indiretamente, afetem:

- a saúde, a segurança e o bem-estar da população;

- as atividades sociais e econômicas;

- a biota;

- as condições estratégicas e sanitárias do meio ambiente;

- a qualidade dos recursos ambientais.

A Constituição Federal de 1988 determina a necessidade de elaboração de Estudo Prévio de Impacto Ambiental e assim se expressa:

Art. $225 \S 1 \stackrel{\circ}{0}$

IV - exigir, na forma da lei, para instalação de obra ou atividade potencialmente causadora de significativa degradação ao meio ambiente, estudo prévio de impacto ambiental, a que se dará publicidade.

E a resolução CONAMA 237/97 define o Estudo de Impacto Ambiental - EIA como:

[...] todos e quaisquer estudos relativos aos aspectos relacionados à localização, instalação, operação e ampliação de uma atividade ou empreendimento, apresentado como subsídio para a análise da licença requerida, tais como: relatório ambiental, plano de recuperação de área degradada e análise preliminar de risco.

O EIA é representado por um conjunto de estudos técnicos que procura descrever, analisar e quantificar tecnicamente todos os impactos ambientais e suas respectivas ações mitigadoras, e a ele seguirá o Relatório de Impacto Ambiental - RIMA - escrito em linguagem não técnica, de fácil acesso ao grande público, e que objetiva tornar possível a ampla publicidade e também o entendimento das ações por parte do público leigo. 
Verifica-se, assim, absoluta semelhança com os procedimentos ambientais levados a efeito nos Estados Unidos, talvez com menor detalhamento no que concerne ao Relatório Científico, exigido pelas autoridades ambientais norte-americanas.

Desta forma, qualquer atividade que se utilize dos recursos naturais, para sua implementação deverá se submeter a: Avaliação dos Impactos Ambientais - AIA, que originará um EIA, que por sua vez será sintetizado num RIMA.

São estes os instrumentos que possibilitarão ao empreendedor solicitar o licenciamento ambiental para a execução de empreendimentos, e que geram três licenças:

- Licença Prévia, que verifica a viabilidade ambiental do empreendimento;

- Licença de Instalação, que autoriza o início das obras;

- Licença de Operação, que autoriza o início da operação.

\subsection{Licenciamento Ambiental no Brasil}

A forma de condução do processo de licenciamento ambiental no Brasil tem sido objeto de fortes discussões: setores do governo ligados às áreas ambientais defendem enfaticamente os procedimentos usados; outros setores do próprio governo questionam, muitas vezes, essas decisões; a sociedade civil organizada, através dos vários campos de interesse que defendem, pronuncia-se conforme suas particularidades; o Ministério Público tem sido um ator importante interferindo e procurando influenciar as decisões dos órgãos ambientais, chegando muitas vezes, quando não atendido em suas proposições, a questionar os licenciamentos judicialmente, que, aliás, faz parte das suas prerrogativas como defensor da sociedade. Ocorre que, muitas vezes, o Ministério Público tem sido induzido a erros por denúncias infundadas e não tendo suficiente qualificação técnica, mas com assessoria às vezes discricionária, tem acarretado atrasos na emissão de licenças ou mesmo até interrompendo empreendimentos já em andamento. 
O licenciamento ambiental, atividade administrativa fundamental para a preservação do meio ambiente, que utiliza os instrumentos de AIA, EIA-RIMA para sua execução, tem sido apresentado como obstáculo para o desenvolvimento, quando na verdade o que objetiva é um ordenamento ambiental do crescimento econômico, para ajudar na promoção da redução das desigualdades com eficiência, preservando os ativos ambientais e/ou mitigando os efeitos do seu uso.

O processo da execução do licenciamento é que tem sido amplamente questionado pelos agentes econômicos, pela sociedade civil e até mesmo pelos órgãos governamentais mais preparados administrativamente; ora tem sido acusado de discricionário, atendendo a interesses específicos, ora de incompetente, pela demora das decisões, fatos que tem suscitado debates e discussões em toda a sociedade interessada conforme seu campo de atuação:

\subsubsection{Os agentes financeiros}

As Agências Internacionais de financiamento, destacando-se o BIRD, o BID e o Japan Bank of International Cooperation - JBIC, têm sido desde a década de 1970, os maiores incentivadores da aplicação da Avaliação Ambiental e dos Estudos dos Impactos Ambientais como instrumentos da política de proteção ambiental e como elementos-chave na concessão das licenças, inserindo em seus financiamentos exigências de análise detalhada para todos os setores.

No Brasil, um dos segmentos que mais tem criticado os métodos e procedimentos do licenciamento ambiental tem sido o setor elétrico.

Tais preocupações levaram o Banco Mundial a elaborar trabalho específico sobre o tema e os principais aspectos levantados podem ser assim sintetizados (BIRD, 2008):

- "O licenciamento ambiental dos projetos hidrelétricos no Brasil é considerado um grande obstáculo para que a expansão da capacidade de geração de energia elétrica ocorra de forma previsível e dentro de 
prazos razoáveis. A não expansão, por sua vez, representaria séria ameaça ao crescimento econômico."

- Observa-se que as questões sociais e ambientais, incluindo os aspectos regulatórios, não são os únicos fatores restritivos à expansão do parque gerador de energia pelo setor privado. Há os riscos hidrológicos, geológicos, a ausência de planejamento nas bacias hidrográficas e de estudos de viabilidade, entre outros

E o mesmo estudo estabelece algumas conclusões entre as principais:

- O Brasil é um dos poucos países, senão o único, a ter um processo trifásico (Licença Prévia, Licença de Instalação e Licença de Operação), com procedimentos separados para a concessão das licenças em diferentes estágios. Tal formato contribui para transferir, repetir ou reintroduzir conflitos, gerando assim um alto grau de incertezas, longos atrasos e com custos de transação igualmente altos.

- O licenciamento ambiental de atividades potencialmente poluidoras é um dos instrumentos da Política Nacional do Meio Ambiente que mais recebeu atenção do poder público nos últimos 26 anos, em função de sua relevância para os investimentos de grande porte.

- O processo de licenciamento oferece poucas oportunidades para a resolução de conflitos.

- As entrevistas com atores envolvidos no processo de licenciamento ambiental para empreendimentos hidrelétricos revelaram o temor dos funcionários de órgãos licenciadores em sofrer possíveis penalidades impostas pelas Leis de Crimes Ambientais (Lei Federal no 9.605/98) e Improbidade Administrativa (Lei Federal no 8.429/92).

- O Ministério Público (MP) tem papel relevante no sistema ambiental do país. É, de maneira geral, entre os atores envolvidos no processo de licenciamento ambiental, o de equipe mais instruída, com mais recursos e amplos poderes. Em boa parte dos casos examinados, 0 MP não se limitou em empregar esses recursos para resolver 
problemas, mas, de fato, representou um estágio adicional - e bastante controverso - no processo de licenciamento ambiental de empreendimentos de grande porte, especialmente aqueles relativos a plantas hidrelétricas.

Destaca-se ainda a absoluta autonomia dos membros do MP, o que constitui fator relevante no exame da implementação do processo de licenciamento ambiental no Brasil. Em outros países, um procurador público não atua da mesma forma. Mesmo nos Estados Unidos, onde o sistema de responsabilidade é considerado robusto, a situação é significativamente diferente.

Nos aspectos técnicos, o referido estudo assim concluiu suas críticas:

- Baixa Qualidade dos TdRs e RIMAs;

- Ausência de informações;

- Interação inadequada entre os órgãos competentes;

- Problemas no fluxo de informações entre os diferentes órgãos envolvidos no processo de licenciamento;

- Problemas no fluxo de informações também caracterizam a relação entre órgãos dos setores energético e ambiental;

- Subjetividade dos princípios e critérios adotados.

Na tentativa de reduzir prazos para a análise dos licenciamentos, o IBAMA emitiu a instrução normativa 065/05, que estabeleceu prazos para cada fase do licenciamento.

Não obstante, esses prazos não são seguidos, como bem o demonstra a tabela 5.4. 


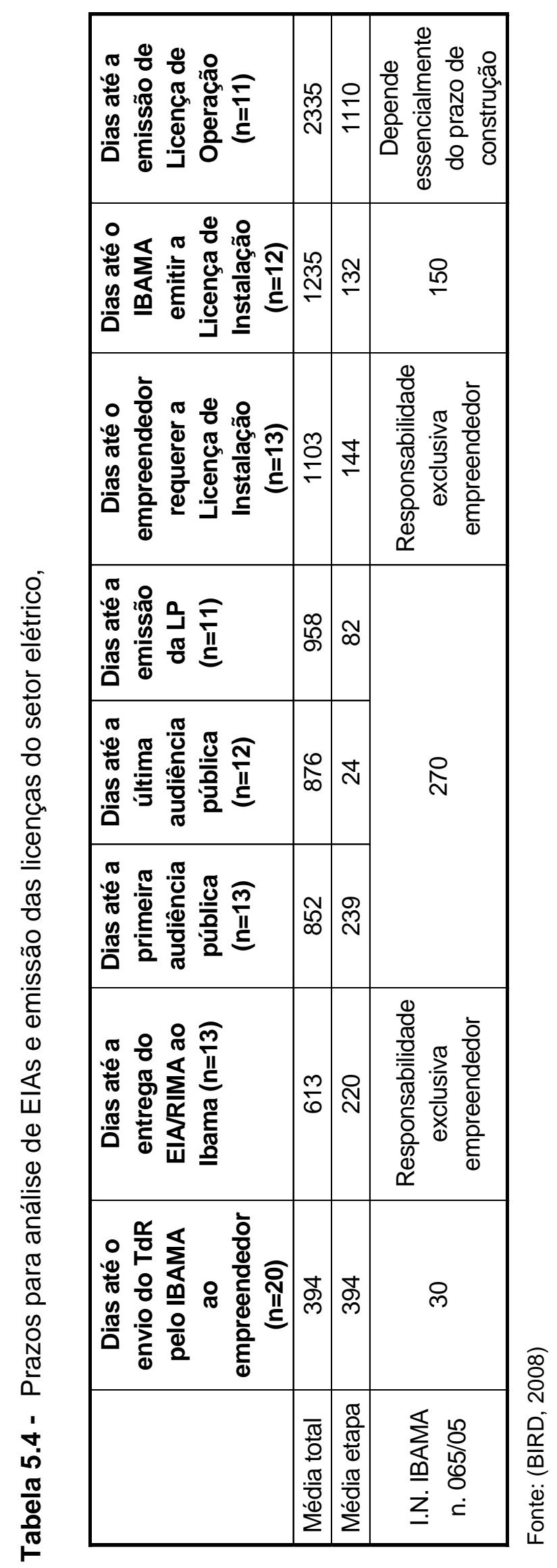


Nos aspectos institucionais, diversas conclusões são apresentadas no estudo, entre elas destaca-se:

"Os órgãos licenciadores possuem recursos humanos e financeiros insuficientes para atender às crescentes necessidades do país."

“...dos 83 funcionários lotados na Diretoria de Licenciamento em Brasília, há apenas um funcionário com especialização na área social (história)."

"Considerando que os aspectos sociais relativos a empreendimentos hidrelétricos têm grande relevância para os custos e prazos implicados no processo de licenciamento ambiental, isso sugere haver necessidade de reforço da equipe da Diretoria de Licenciamento do IBAMA na área social."

A Tabela 5.5 mostra o quadro de pessoal do IBAMA entre 2002 e 2006:

Tabela 5.5 - Distribuição do quadro de funcionários do IBAMA de 2002 a 2006

\begin{tabular}{l|c|c|c|c|c}
\hline \multirow{2}{*}{ Pessoal } & \multicolumn{5}{|c}{ ANO } \\
\cline { 2 - 6 } & $\mathbf{2 0 0 2}$ & $\mathbf{2 0 0 3}$ & $\mathbf{2 0 0 4}$ & $\mathbf{2 0 0 5}$ & $\mathbf{2 0 0 6}$ \\
\hline Analista Ambiental (servidor) & 6 & 62 & 79 & 115 & 120 \\
\hline Consultor Técnico PNUD (Equipe de base) & 70 & 68 & 54 & 13 & 4 \\
\hline Consultor Técnico PNUD (Produto) & 0 & 0 & 0 & 22 & 12 \\
\hline Total & $\mathbf{7 6}$ & $\mathbf{1 3 0}$ & $\mathbf{1 3 3}$ & $\mathbf{1 5 0}$ & $\mathbf{1 3 6}$ \\
\hline
\end{tabular}

Fonte: IBAMA (2007)

Aspecto relevante dos processos de licenciamento tem sido não somente os prazos longos para sua obtenção, mas também os custos que estão implicados no processo.

Em sua análise, o Banco Mundial assim desagregou os custos implicados no licenciamento (Tabela 5.6): 
Tabela 5.6 - Custos relacionados ao licenciamento de empreendimentos em hidrelétricas

\begin{tabular}{l|c|c}
\hline CUSTO & US $\$$ KW INSTALADO & PARCELA TOTAL (\%) \\
\hline Custos Diretos & 133 & 14,1 a 14,7 \\
\hline i) Sociais & 94 & 10,0 a 10,4 \\
\hline ii) Ambientes Físicos & 19 & 2,0 a 2,1 \\
\hline iii) Incerteza regulatória & 20 & 2,1 a 2,2 \\
\hline Indiretos(oportunidade) & 19 a 50 & 1,1 a 5,4 \\
\hline Total do Licenciamento Ambiental & 143 a 183 & 15,2 a 20,1 \\
\hline Médio total do KW instalado & 906 a 946 & 100 \\
\hline
\end{tabular}

Fonte: adaptado de BIRD (2008)

Ao final, o estudo faz algumas recomendações:

- Necessidade de considerar a formulação e adoção de Lei Complementar, esclarecendo as responsabilidades da União e dos Estados em relação ao licenciamento ambiental (artigo 23, inciso VI, da Constituição Federal de 1988);

- O estabelecimento do interesse federal previamente ao início do processo de licenciamento e/ou o reconhecimento da jurisdição sobre a bacia hidrográfica onde se localiza o projeto podem ser alternativas a serem consideradas para a superação do problema;

- Criação e promoção de mecanismos de resolução de conflitos entre os atores do processo de licenciamento;

- Convênios de Cooperação entre MPs da União e dos Estados e órgãos ambientais, incluindo emissão de diretrizes pelo CNMP;

- É necessário que os planos, políticas e programas referentes ao setor elétrico considerem as questões sociais e ambientais, juntamente com os aspectos econômicos, técnicos e financeiros, desde o início da sua elaboração e permitam a participação dos diferentes grupos de interesse; 
- A LP deve ser considerada (e emitida) com base na análise realizada na etapa de planejamento. A prática atual, a qual exige um EIA-RIMA detalhado para a obtenção da LP, deveria ser modificada para um processo que envolvesse diversas agências, sendo que todas deveriam incorporar as variáveis ambientais e sociais. O EIA-RIMA do empreendimento tornar-se-ia, então, um requerimento para a obtenção da LI, com base no projeto de engenharia;

- A elaboração de TdR por equipe multidisciplinar baseada em processo de análise prévia do empreendimento e da região onde se insere, com base em informações secundárias e em pelo menos uma vistoria de campo;

- Aperfeiçoamento da capacitação técnica e diversificação do corpo profissional dos órgãos do SISNAMA e do setor privado envolvidos no processo de licenciamento ambiental;

- Com base nas diretrizes, princípios e critérios definidos, os órgãos do SISNAMA poderiam, em conjunto com entidades de ensino superior, desenvolver uma ementa de curso de especialização de média duração para a capacitação de técnicos, tanto para a elaboração de EIA-RIMA, quanto para a sua análise. $O$ ideal é que, em médio prazo, essa habilitação específica torne-se uma exigência para os técnicos seniores, responsáveis pela coordenação da elaboração de EIARIMAs;

- Criação de Conselho de Governo conforme já previsto na Lei Nacional de Política Ambiental com a responsabilidade pelo encaminhamento de várias das ações anteriormente descritas. Tal Conselho de Governo, que não substituiria o CONAMA na sua função de deliberar, no âmbito de sua competência, sobre normas e padrões compatíveis com o meio ambiente, teria a competência de promover a coordenação entre as agências governamentais e contribuir no aprimoramento do processo de planejamento. 
$\mathrm{Na}$ visão do Banco Mundial, o instrumento mais comumente usado na América Latina para regular a gestão ambiental dos empreendimentos é a AIA, que, no entanto, não é suficiente para garantir uma gestão ambiental bem sucedida.

Apesar de todos os países da América Latina terem implementado sistemas de avaliação dos impactos ambientais, eles mostram diferentes graus de desenvolvimento de arranjos institucionais.

Os aspectos positivos estão relacionados com a formação de uma consciência ambiental na região, maior desenvolvimento da engenharia de projetos, planejamento, construção e operação de obras de infra-estrutura. Redução dos desastres ecológicos, maior demanda por serviços, maior necessidade de capacitação acadêmica e expansão, ainda que em escala menor que a desejada, da participação popular nas decisões sobre os projetos.

Há, porém, um consenso que é necessário uma ampla reforma dos sistemas de avaliação ambiental na América Latina, focando nas necessidades e prioridades de cada país, pois os sistemas de licenciamento ambiental têm mostrado limitações para gerenciar os grandes temas ambientais, são considerados de pouca efetividade e percebidos cada dia mais como entraves ao desenvolvimento.

Os sistemas não foram complementados com outros instrumentos de gestão, as licenças são quase o único ponto de contato entre o meio ambiente e os outros setores; a qualidade das AIAs é baixa, houve um estancamento metodológico, a abertura do processo ao público é limitada, não fortalecem os processos de planejamento e há excessiva burocratização das AIA.

A gestão ambiental dos países da América Latina pode ser sintetizada numa escala que percorre o espectro de valores, que vai desde o alto desempenho com fraquezas em algumas áreas até o mais baixo aonde esse conceito ainda nem chegou a ser considerado conforme mostra a tabela 5.7. 
Tabela 5.7 - Avaliação da efetividade da AIA na proteção ambiental nos países da América Latina

\begin{tabular}{l|l}
\hline Alto desempenho & $\bullet$ Nenhum país latino-americano \\
\hline Algumas áreas fracas & $\bullet$ Brasil \\
\hline Positivo com fraquezas significativas & $\bullet$ Chile \\
& $\bullet$ Colômbia \\
\hline Progresso, porém resultado negativo & $\bullet$ Uruguai \\
& $\bullet$ México \\
& $\bullet$ Panamá \\
\hline Algum progresso, todavia negativo & $\bullet$ El Salvador \\
\hline Negativo, não começou & $\bullet$ Venezuela \\
& $\bullet$ Guatemala \\
& $\bullet$ Honduras \\
& $\bullet$ Bolívia \\
& $\bullet$ Nicarágua \\
& $\bullet$ República Dominicana \\
& $\bullet$ Equador \\
& $\bullet$ Paraguai \\
\hline
\end{tabular}

Fonte: World Economic Forum (2004)

A Região Latino Americana reconhece a necessidade de instrumentos mais eficientes: a responsabilidade ambiental setorial e corporativa; a mescla de instrumentos ambientais; a necessidade de mudanças inovadoras nas Avaliações de Impactos Ambientais, tais como: desregulamentação, delegação setorial, fortalecimento setorial e licenças em grupo.

Esses problemas e ineficiências afetam fortemente a competitividade dos países, conforme mostra a tabela 5.8 do Relatório de Competitividade Mundial, (WORLD ECONOMIC FORUM,2004) 
Tabela 5.8 - Posição dos países na competitividade mundial em função das características dos regulamentos ambientais

\begin{tabular}{l|c|c}
\hline INDICADOR & LíDER MUNDIAL & $\begin{array}{c}\text { POSIÇÃO DO LÍDER NA } \\
\text { AMÉRICA LATINA }\end{array}$ \\
\hline Rigor dos regulamentos ambientais & Alemanha & $\begin{array}{c}\text { Brasil (25) } \\
\text { Colômbia (41) }\end{array}$ \\
\hline $\begin{array}{l}\text { Clareza e estabilidade dos } \\
\text { regulamentos ambientais }\end{array}$ & Dinamarca & $\begin{array}{c}\text { Chile (38) } \\
\text { Colômbia (50) }\end{array}$ \\
\hline $\begin{array}{l}\text { Impacto dos regulamentos ambientais } \\
\text { sobre a competitividade empresarial }\end{array}$ & Dinamarca & $\begin{array}{c}\text { Chile (37) } \\
\text { Colômbia (78) }\end{array}$ \\
\hline $\begin{array}{l}\text { Informações ambientais nas empresas } \\
\text { planejamento dos investimentos }\end{array}$ & Dinamarca & $\begin{array}{c}\text { Brasil (32) } \\
\text { Colômbia (59) }\end{array}$ \\
\hline $\begin{array}{l}\text { Importância do ambiente para o } \\
\text { Panamá (28) }\end{array}$ & Japão & Colômbia (66) \\
\hline
\end{tabular}

Fonte: World Economic Forum , 2004

\subsubsection{Associações Empresariais}

\subsubsection{A Confederação Nacional das Indústrias - CNI}

A 48ํㅡㄹ Reunião do Conama, realizada na cidade de São Paulo, em agosto de 2006, teve como objetivo analisar e discutir com a sociedade civil organizada as questões do licenciamento ambiental.

A CNI manifestou sua posição, definindo que o EIA deve:

- Ser instrumento de tomada de decisão, que integre as variáveis ambientais, econômicas sociais e tecnológicas;

- Promover a adoção de métodos e técnicas nos processos produtivos para se obter o produto com menor impacto ambiental possível;

- Viabilizar a atividade econômica, apontando mecanismos para sua instalação com menor impacto ambiental; 
- Estabelecer informações para um planejamento que incorpore a questão ambiental e

- Amparar-se em estudos e conhecimento técnico científico.

Em sua análise, a CNI destaca que o licenciamento:

- Deixa, cada vez mais, de ser um processo de planejamento, não se propondo a conciliar os princípios constitucionais de desenvolver e conservar. Torna-se cada vez mais um processo cartorial;

- Ganha feições de um instrumento de negociação para preencher lacunas advindas do enfraquecimento institucional;

- Tem aplicação dissociada de todo um programa de desenvolvimento econômico-social, fazendo análises pontuais.

Em sua crítica em relação ao EIA destaca:

- Perdeu o fundamento proposto na resolução Conama nº 01/86;

- Reflete mais questões sociais que ambientais;

- Desvirtua-se da sua função preventiva;

- Ganha uma dimensão desproporcional;

- Contamina-se com o processo cartorial do licenciamento;

- Tem procedimentos não uniformes - atribuem-se pesos e medidas diferenciados para projetos da mesma natureza;

- É indeterminado no que se refere a quem e quando se aplica;

- Fomenta a judicialização da gestão ambiental;

- Tem elevado custo social, econômico e político - aumenta o custo Brasil e promove cenários de barganha política;

- Tende a ter uma análise e concepção mais política que técnica; 
- A não sistematização, consolidação e validação dos resultados tornam os estudos mais caros, dificultam a análise sistêmica e sinérgica;

- Reflete uma duplicação de esforços: empreendedor contrata equipe multidisciplinar para executar e o poder público contrata especialistas para analisar.

E propõe as seguintes recomendações:

- Resgatar o licenciamento ambiental como instrumento de gestão;

- Resgatar o papel do EIA através da aplicação mais adequada da resolução 01/86, utilizando-o como instrumento de suporte a decisão, com vistas a buscar a viabilidade ambiental de um determinado projeto, procedendo a uma análise mais técnica que política, oferecendo suporte mais adequado às Audiências Públicas;

- Definir uma nova sistemática de contratação ou elaboração dos estudos de forma a evitar a duplicação de esforços;

- Implementar o Sistema de Informações para a consolidação dos EIAs como suporte para análise e concepção;

- Fortalecimento do planejamento como instrumento da integração de políticas públicas, tais como o Plano Nacional de Desenvolvimento e a Avaliação Ambiental Estratégica;

- Fortalecimento das políticas públicas de educação e de ciência e tecnologia;

- Fortalecimento de instituições públicas, através de equipes capacitadas, bem remuneradas; a segurança jurídica dos procedimentos; a clara definição das competências das entidades públicas envolvidas no processo e respeito e promoção do pacto federativo. 
Em encontro nacional posterior (CNI 2006), no qual o principal item discutido foi a necessidade de simplificação do licenciamento através de uma proposta que "harmonize as exigências para a obtenção das licenças ambientais nos Estados, incluindo a definição de critérios de inserção de condicionantes sociais e os seus limites"; abordou também a necessidade de diálogo com o Ministério Público, enfatizando a necessidade de imposição de limites e responsabilidades legais para os agentes que proponham processos judiciais prejudiciais às empresas e que se mostrem sem fundamentos. Incentivou a participação ativa do setor industrial na elaboração do Zoneamento Ecológico Econômico.

O trabalho indicou alguns encaminhamentos específicos que são:

- Elaborar estudo comparativo entre todas as legislações estaduais de licenciamento ambiental, objetivando harmonizar suas regras, seus prazos e custos e promover a sua simplificação em todo o país;

- Fundamentar a elaboração de uma proposta do setor industrial para o estabelecimento de critérios de inclusão de condicionantes de caráter social no processo de licenciamento ambiental e de abatimento dos custos associados a condicionantes sócio-ambientais dos montantes de compensação ambiental;

- Investigar mecanismos formais que possam ser utilizados para regulamentar os papéis, competências e responsabilidades, e coibir excessos de atores indiretamente envolvidos nos processos de licenciamento ambiental de empreendimentos.

Quanto às compensações ambientais, tema de crescente importância no setor, as propostas foram:

- A gestão dos recursos financeiros da compensação ambiental deve ser transparente e que haja a participação de forma paritária de representantes diretamente envolvidos do Poder Público, da sociedade civil organizada e do setor produtivo; 
- Elaborar proposta de alteração na metodologia de cálculo da compensação ambiental que considere os benefícios ambientais, econômicos e sociais na implantação dos empreendimentos.

A preocupação do setor industrial deu lugar a uma pesquisa interna, procurando definir os principais problemas da indústria no processo de licenciamento ambiental.

A pesquisa levantou a quantidade de empresas que precisaram da licença ambiental e as que enfrentaram problemas para a obtenção da mesma. Entre os principais problemas, avaliaram: demora nas análises; custos para atender as exigências dos órgãos ambientais; dificuldades para atender aos critérios técnicos exigidos; custos para a preparação dos estudos e dos projetos e dificuldades para identificar especialistas nos temas exigidos. O resultado é mostrado na figura 5.1 .

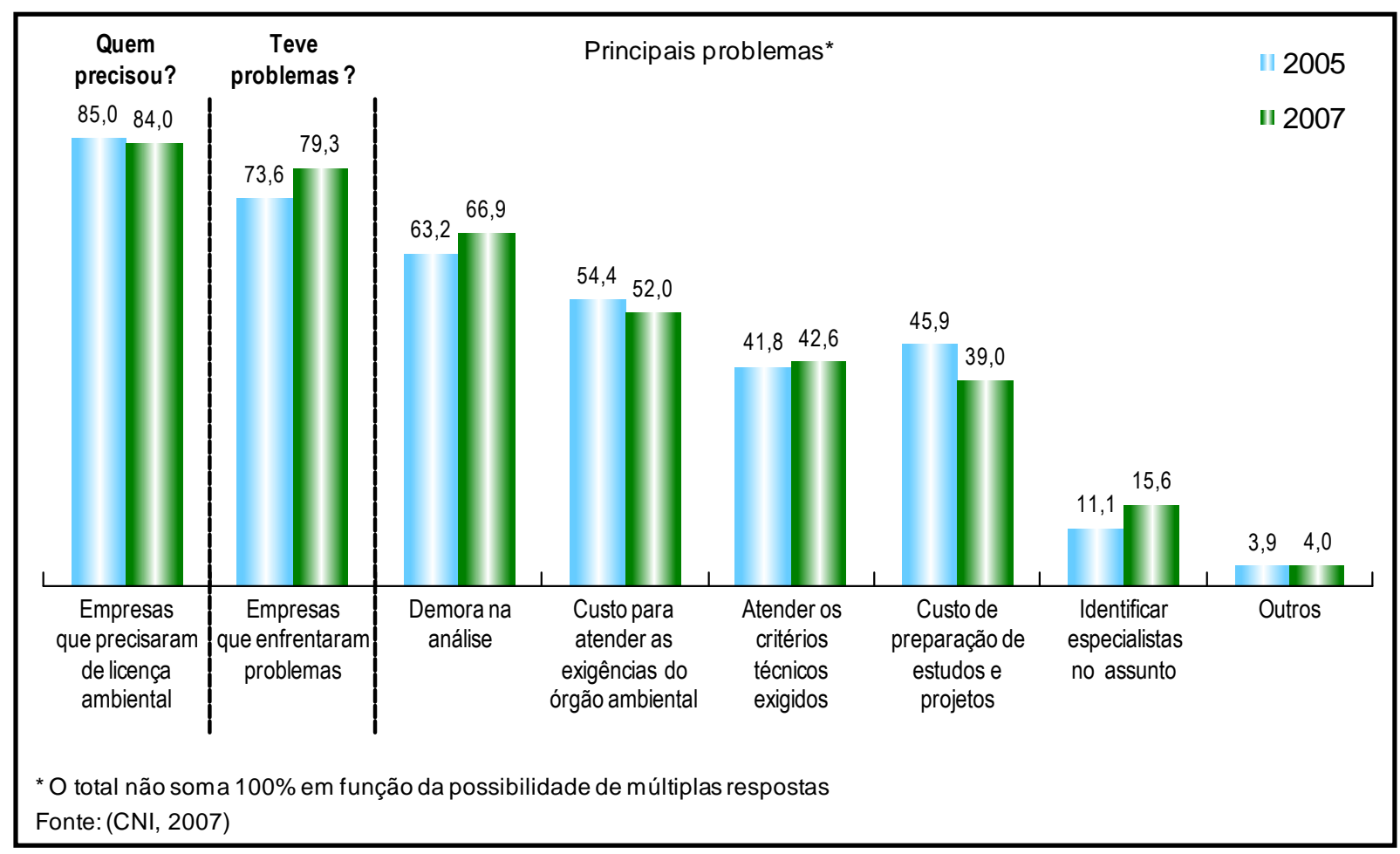

Figura 5.1 - Principais problemas enfrentados pela indústria no processo de licenciamento Fonte: CNI (2007)

Não raro os problemas enfrentados pelo setor têm provocado tensões no relacionamento entre as partes, que também foi objeto da pesquisa, que analisou as 
seguintes variáveis entre as empresas que se relacionam com os diversos órgãos ambientais: empresas que enfrentaram problemas; requisitos exagerados da regulamentação; custos de implantação da regulamentação; complexidade do regulamento; falta de preparo técnico da fiscalização; alterações extemporâneas da regulamentação e comportamento da fiscalização.

O resultado da pesquisa está sintetizado no gráfico mostrado na figura 5.2.

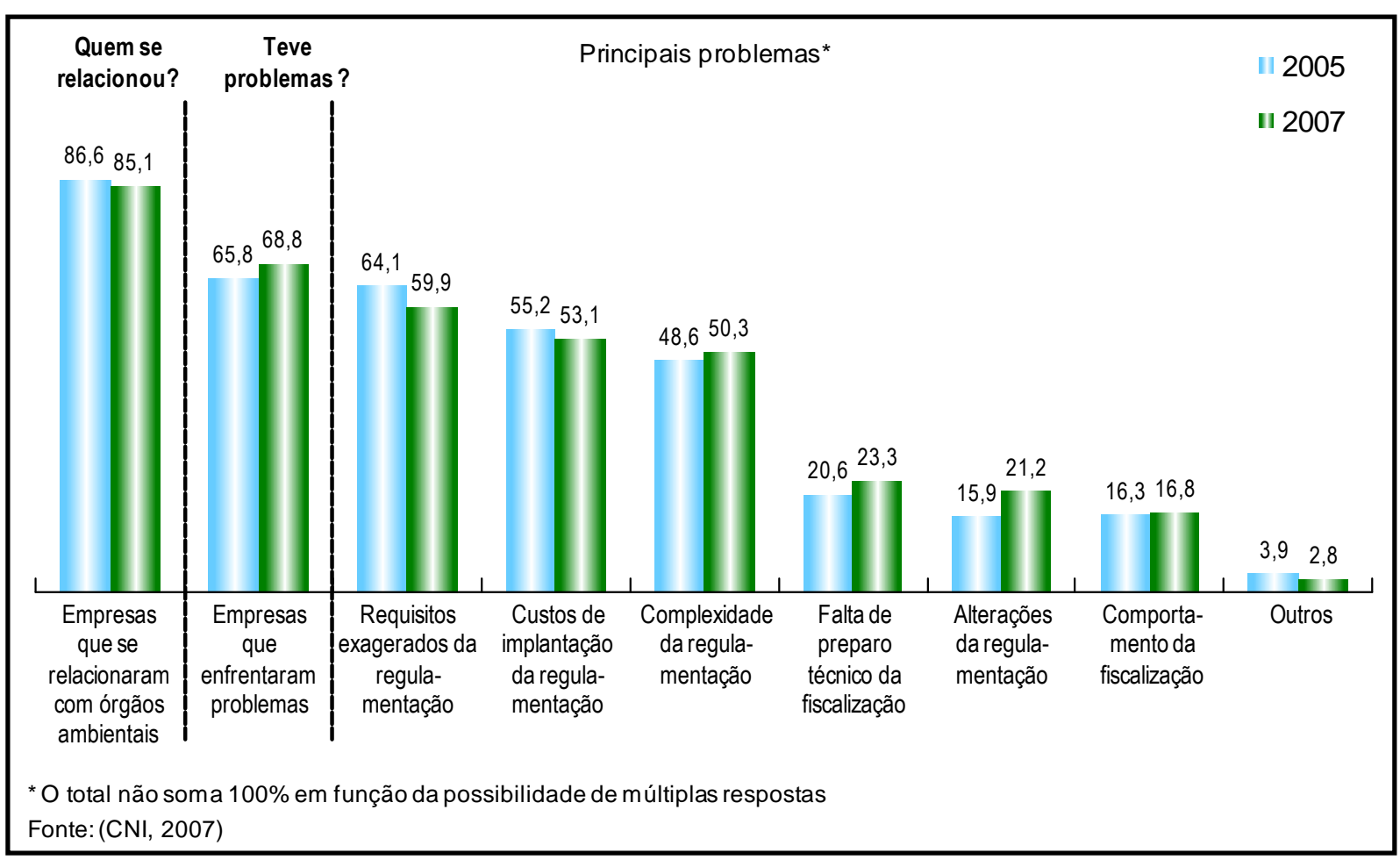

Figura 5.2 - Principais problemas na relação entre as empresas e os órgãos ambientais (\%) Fonte: CNI (2007)

\subsubsection{Associação Brasileira de Infra Estrutura e Indústria de Base - ABDIB}

A ABDIB tem questionado com insistência as diversas fases do processo de licenciamento ambiental e em particular, sua preocupação se concentra no setor elétrico, forte demandante de equipamentos e serviços dos seus representados.

Segundo levantamento elaborado em 2005, era a seguinte a situação dos diferentes empreendimentos em processo no IBAMA (Tabela 5.9). 
Tabela 5.9 - Situação do licenciamento ambiental de empreendimentos elétricos no IBAMA em 2005

\begin{tabular}{c|cc}
\hline Número de empreendimentos & Potência (MW) & Situação \\
\hline 18 & 3.919 & Sem licença prévia (LP) \\
\hline 4 & 1.055 & Com LP \\
\hline 4 & 564 & Com LP e LI (obras não iniciadas) \\
\hline 17 & 4.242 & Com LP e LI (obras iniciadas) \\
\hline 3 & 4.441 & Com LP, LI e LO (licença de operação) \\
\hline Total = 46 & & \\
\hline
\end{tabular}

Fonte: ABDIB (2005)

Constata-se que dos 46 empreendimentos em tramitação no IBAMA, somente três estavam liberados.

Esta situação demandou um trabalho conjunto ABDIB-IBAMA na tentativa de identificar os problemas e formular propostas de solução; para tanto, o processo de licenciamento foi desagregado em suas diferentes etapas e foram analisados os diferentes problemas e alternativas de solução (Tabela 5.10). 
Tabela 5.10 - Problemas no licenciamento de empreendimentos elétricos e alternativas de soluções propostas pelo ABDIB/IBAMA

\begin{tabular}{|c|c|}
\hline PROBLEMAS & ALTERNATIVAS \\
\hline $\begin{array}{l}\text {-55 dias para enquadramento do } \\
\text { empreendimento }\end{array}$ & $\begin{array}{l}\text { - Sistema on line para enquadrar o } \\
\text { empreendimento }\end{array}$ \\
\hline $\begin{array}{l}\text { - Termo de referência é discutido por um } \\
\text { período muito longo de tempo }\end{array}$ & $\begin{array}{l}\text { - Elaborar modelos de termos de } \\
\text { referência }\end{array}$ \\
\hline $\begin{array}{l}\text { - Qualidade dos relatórios apresentados é } \\
\text { insuficiente, o que demanda maior tempo } \\
\text { de análise }\end{array}$ & $\begin{array}{l}\text { - Cadastro de credenciamento de } \\
\text { empresas/instituições/profissionais nas } \\
\text { diferentes áreas de especializações }\end{array}$ \\
\hline $\begin{array}{l}\text { - Complementações da documentação } \\
\text { técnica }\end{array}$ & $\begin{array}{l}\text { - A solicitação de novas complementações } \\
\text { deverá ser feita uma única vez }\end{array}$ \\
\hline $\begin{array}{l}\text { - Análise dos estudos somente após o } \\
\text { recebimento do parecer dos outros } \\
\text { órgãos }\end{array}$ & $\begin{array}{l}\text { - Reduzir prazos para os órgãos emitirem } \\
\text { pareceres (2 meses) } \\
\text { - O próprio interessado poderia } \\
\text { encaminhar os documentos aos demais } \\
\text { órgãos } \\
\text { - Instituir aprovação por decurso de prazo }\end{array}$ \\
\hline $\begin{array}{l}\text { - Definição do valor das compensações } \\
\text { ambientais }\end{array}$ & $\begin{array}{l}\text { - Participação do setor produtivo na } \\
\text { definição. } \\
\text { - Os custos não deveriam cair somente } \\
\text { sobre todo o investimento das obras, mas } \\
\text { também sobre a construção e } \\
\text { equipamentos. }\end{array}$ \\
\hline $\begin{array}{l}\text { - Ações judiciais contra representantes do } \\
\text { IBAMA inibem as emissões de licenças }\end{array}$ & $\begin{array}{l}\text { - Propiciar a defesa dos Agentes através } \\
\text { do Jurídico do IBAMA }\end{array}$ \\
\hline \multicolumn{2}{|l|}{ - Renovação da LI } \\
\hline $\begin{array}{l}\text { - Ações de ONGs junto aos órgãos } \\
\text { ambientais, retardando a concessão das } \\
\text { licenças }\end{array}$ & $\begin{array}{l}\text { - Estabelecer desde o início critérios claros } \\
\text { de negociação com as comunidades } \\
\text { atingidas }\end{array}$ \\
\hline
\end{tabular}

Fonte: ABDIB (2005)

A análise das quarenta e oito atividades que devem ser percorridas para a obtenção do licenciamento demonstrou que os prazos para consegui-lo no IBAMA são de no mínimo 26 meses para um empreendimento de classe I - com significativo impacto ambiental. 
O IBAMA dividiu os empreendimentos em vinte e duas classes, que seguem o mesmo rito, com prazos dependendo da maior ou menor complexidade (IBAMA, 2002).

\subsection{3 Órgãos Estaduais}

As agências estaduais seguem integralmente o modelo do IBAMA, com os mesmos procedimentos, as mesmas fases e por conseqüência apresentam as mesmas virtudes e defeitos do sistema nacional.

Em seminário realizado em Brasília, sob a orientação do Conama, em março de 2005, tratando especificamente do licenciamento ambiental dos sistemas de esgoto sanitário, houve oportunidade para os Estados da federação discutirem o tema.

Todos procuraram mostrar as razões pelas quais há um grande apelo para a alteração do sistema de licenciamento ambiental e defenderam as posições que os Estados têm assumido até aqui, procurando justificar as razões pelas quais os prazos da obtenção das licenças são tão longos, e no caso específico, a discussão ficou centrada numa atividade essencial, que é o sistema de esgoto sanitário.

Poucos Estados fizeram avaliação crítica dos procedimentos, nenhum questionou a tripla licença, mesmo para obras de saneamento, e alguns apresentaram alternativas de solução, a seguir descritas.

\section{A) Pernambuco}

Com o objetivo de agilizar o processo, o Estado de Pernambuco sugere:

- Criar auditorias internas nas Organizações Estaduais de Meio Ambiente - OEMAS;

- Uniformizar os procedimentos de licenciamento;

- Permitir que sejam concedidas licenças de instalação com prorrogação de prazo de cumprimento das exigências essenciais, para 0 funcionamento do empreendimento e o controle ambiental; 
- Tornar o poder fiscalizador mais atuante e eficiente;

- Vincular as parcelas do financiamento dos projetos dos sistemas de esgoto sanitário às diversas fases do licenciamento ambiental, principalmente no tocante à licença de operação.

B) Bahia

A Bahia, por sua vez, além de exigir a Licença Prévia, a Licença de Instalação e a Licença de Operação, ainda acrescentou a Licença de Localização, a Licença Precária de Operação, com 120 dias de validade antes da LO, a Licença de Alteração e a Licença Simplificada.

\section{C) Tocantins}

O estado de Tocantins segue as mesmas regras do IBAMA, com a inovação de que estabelece prazos para a expedição das diferentes licenças conforme o porte do empreendimento; para a LP, o prazo varia de 8 a 12 meses; para a LI, de 4 a 6 meses, e para a LO, 2 a 3 meses.

\section{D) Minas Gerais}

O Estado de Minas Gerais emite a tripla licença e estabelece algumas simplificações em função do porte do empreendimento.

\section{E) Espírito Santo}

O Estado do Espírito Santo apresentou a mais elaborada análise e fez uma forte auto-crítica em relação ao processo.

No seu sistema, o Estado estabeleceu a necessidade de obtenção das seguintes licenças: 
- Licença Prévia;

- Licença de Instalação;

- Licença de Operação;

- Autorização Ambiental - AA;

- Licença de Operação Provisória - LOP;

- Termo de Responsabilidade Ambiental - TRA;

- Licença de Regularização - LR;

- Licença Ambiental Conjunta;

- Licença Simplificada - LS;

- Carta Consulta.

Em uma crítica reflexiva, lista como os entraves do licenciamento ambiental:

- Burocracia;

- Mudança de exigências no meio do licenciamento;

- Confusão entre o que é motivo para LP, LI e LO;

- Falta de razoabilidade na aplicação de sanções por descumprimento parcial das licenças;

- Atribuição indevida de responsabilidades ao empreendedor na não execução de exigências ambientais com participação de terceiros;

- Processo muito longo e burocrático, cheio de pontos de decisão com critérios pouco claros;

- Aplicação indevida e excessiva do Princípio da Prevenção;

- Ausência de um código consolidado de regras ambientais; 
- Tratamento de casos mais simples e de menor impacto da mesma forma que empreendimentos e/ou atividades complexas e/ou de alto impacto;

- Inexistência de sistemas de informatização;

- Quadro reduzido e despreparado de pessoal;

- Desequilíbrio de responsabilidades entre consultores e os técnicos do Instituto Estadual de Meio Ambiente (IEMA);

- Ausência de normas e procedimentos padrões para licenciamento por tipologias de atividades;

- Conflito de competências entre IBAMA e OEMAS;

- Receitas geradas não são utilizadas no processo;

- A cada novo empreendimento, os padrões técnicos de exigências tornam-se mais rigorosos;

- Análise econômica dos cenários não é verificada em relação a outros Estados ou mesmo países;

- São esquecidas as condições vigentes: o cenário sem o empreendimento;

- O que é melhora da Qualidade Ambiental do uso do território fica vagamente visto como prejudicial;

- Grandes empreendimentos: compensações inadequadas (extrapolando a legislação) por desconhecimento e insegurança em relação a questionamentos futuros do MP;

- Não há aferição da eficácia da adoção das medidas de controle e mitigação.

Ainda, na sua visão crítica, o representante do Estado do Espírito Santo expõe e analisa a atuação do Ministério Público nos seguintes termos: 
- Questionam a funcionalidade da audiência pública;

- Questionam a capacidade intelectual da população para discutir o RIMA;

- Envio excessivo de solicitações e explicações técnicas com curto espaço para resposta e diversidade de tópicos;

- Questionam a capacidade dos órgãos de controle ambiental para exercerem suas tarefas de forma eficaz e eficiente;

- Atuam como órgão do SISNAMA sem competência para isso.

Em relação aos empreendedores, a Secretaria do Meio Ambiente do Espírito Santo, pelo seu órgão licenciador, o IEMA, assim analisa:

- Licenciamento realizado tardiamente no processo de tomada de decisão, quando o empreendimento integra plano governamental mais amplo;

- Ignora formalmente cenários traçados pelo planejamento público face ao empreendimento, prejudicando a análise estratégica de suas alternativas;

- Reduz o cenário estratégico onde deve inserir-se o empreendimento, inoculando desvios de ordem ideológica e conceitual nas condições do licenciamento;

- Avaliação parcial e insuficiente dos efeitos sinérgicos-cumulativos no longo prazo;

- Qualidade dos estudos ambientais deficientes, com várias solicitações de complementos;

- Ausência de integração - dimensões ambiental, social e econômica;

- Consultores sem critérios de qualificação e exigências mínimas para exercer a profissão; 
- Não incorporam a variável ambiental desde o planejamento do empreendimento;

- Subestimam os impactos sócio-ambientais;

- Subestimam as audiências públicas;

- Informação excessiva - curiosidade acadêmica;

- Divergência na metodologia da avaliação de impactos;

- Excessivo direcionamento nos estudos acadêmicos e pouca importância quanto ao controle ambiental, seu monitoramento e impactos.

Após essa contundente análise dos problemas, as alternativas de soluções sugeridas foram:

- Descentralização;

- Elaboração de normas e procedimentos padronizados;

- Capacitação profissional - aumento do número de profissionais;

- Revisão e adequação da legislação;

- Estabelecimento de mecanismos de avaliação da qualidade do trabalho das consultorias.

\subsubsection{O Sistema de Licenciamento Ambiental no Estado de São Paulo}

\subsubsection{Histórico}

A poluição de ativos ambientais tem sido uma preocupação constante no Estado de São Paulo; já na implantação do Sistema Billings, na década de 1940, advertia-se quanto aos problemas que poderiam advir caso não se fizesse o controle da poluição das águas. 
Em 1953, através da lei $n^{0} .2182$ de 23 de julho de 1953, promulgada pelo governador do Estado, Prof. Lucas Nogueira Garcez, foram estabelecidas as "normas tendendes a evitar a contaminação e poluição das águas litorâneas ou interiores, correntes ou dormentes, e dá outras providências".

Assim se expressava a lei $n^{\circ} .2 .182$ :

Artigo 1: Os efluentes das redes de esgotos, os resíduos líquidos das indústrias e os resíduos sólidos domiciliares ou industriais somente poderão ser lançados nas águas "in natura" ou depois de tratados quando as águas receptoras, após o lançamento, não se tornarem poluídas.

Parágrafo único: Para efeito deste artigo, considera-se "poluição" qualquer alteração das propriedades físicas, químicas e biológicas das águas que possa constituir prejuízo à saúde, à segurança e ao bem estar das populações e ainda possa comprometer a utilização das águas para fins agrícolas, comerciais, industriais e recreativas.

A essa primeira definição legal de poluição, se seguia o embrião da classificação das águas:

Artigo 2: Na regulamentação desta lei, as águas do Estado serão classificadas de acordo com o seu uso preponderante, fixando-se taxas de poluição admissíveis para os efluentes domésticos e industriais e os padrões de poluição para os corpos de água receptores.

Estabelecia responsabilidades de fiscalização e controle:

Artigo 3: Ficam cometidas as atribuições decorrentes desta lei às seguintes repartições:

I. ao Departamento de Obras Sanitárias, da Secretaria de Viação e Obras públicas, o estudo e aprovação de planos e projetos das instalações depuradoras de resíduos, bem como a fiscalização de sua execução, excetuadas as relativas à Capital do Estado, que ficam a carga da Repartição de Águas e Esgotos;

II. À Secretaria da Saúde Pública e da Assistência Social e à Secretaria da Agricultura, por seus órgãos especializados, a fiscalização da poluição das águas do Estado; e 
III. À Repartição de Águas e Esgotos, as mesmas atribuições constantes do item I anterior, relativas à Capital do Estado.

Criava os instrumentos de controle:

Artigo 5: Fica criado junto à Secretaria de Viação e Obras Públicas, o Conselho Estadual de Controle da Poluição das Águas - CECPA, que será integrado por 5 (cinco) membros a saber:

I. Um representante do Departamento de Obras Sanitárias da Secretaria de Viação e Obras Públicas;

II. Um representante da Repartição de Águas e Esgotos da Secretaria de Viação e Obras Públicas;

III. Um representante da Engenharia Sanitária do Departamento de Saúde da Secretaria da Saúde Pública e da Assistência Social;

IV. Um representante do Departamento da Produção Animal da Secretaria da Agricultura; e

V. Um representante da Federação das Indústrias do Estado de São Paulo, escolhido em lista tríplice.

Fixava as atribuições do CECPA, destacando:

Artigo 6ㅇ:

I. Coordenar os trabalhos das diversas repartições interessadas nesta lei;

II. Fixar padrões mínimos iniciais para a proteção das águas;

V. Organizar planos de saneamento das águas naturais e programar a sua execução;

VI. Estabelecer normas para o exercício da fiscalização, especificando métodos de amostragem e análises a serem realizadas; ...

Em 14 de julho de 1955, foi editada a lei no 3.068, que dava nova redação aos artigos $1^{\circ}$ e $4^{\circ}$ da lei $n^{\circ} 2.182 / 53$ e essa nova redação dividiu o parágrafo único em dois: no 1ํㅜㄹ introduziu a fauna ictiológica e no $2^{\circ}$, os primeiros passos do licenciamento ambiental:

§2: o lançamento de resíduos de que trata este artigo dependerá de autorização expressa do Centro de Saúde ou do Posto de Assistência 
Médico-Sanitária local, que comunicará seu ato ao Conselho Estadual de Controle da Poluição das Águas"

O Decreto Estadual n 24.806 de 25 de julho de 1955 regulamentou as duas leis anteriores e estabeleceu a classificação das águas naturais do Estado e as dividiu em seis classes. No capitulo II, que se refere ao tratamento de resíduos, reafirmou a necessidade de licença ambiental para os estabelecimentos industriais:

Artigo 4: Para a construção e ampliação dos estabelecimentos industriais do Estado de são Paulo é obrigatória a aprovação prévia pelas autoridades sanitárias locais dos planos e projetos que incluam:

a) Estimativas do consumo de água, do volume dos despejos líquidos, do número total de empregados e das quantidades de matérias primas a serem utilizadas;

b) O exame das condições locais no que diz respeito ao afastamento das águas residuárias, mostrando a necessidade ou não do tratamento;

c) O sistema adotado para o seu tratamento, sempre que necessário, e com a devida justificação.

Parágrafo Único: Este artigo aplica-se não somente às zonas denominadas urbanas, mas também às zonas denominadas suburbanas e rurais.

Artigo 6: Nenhum novo lançamento de águas ou sólidos residuários poderá ser feito nos corpos de água do Estado sem um alvará expedido expressamente para esse fim pelas autoridades sanitárias após a aprovação dos planos e projetos a que se referem os artigos $4^{\circ}$ e $5^{\circ}$

Em 19 de fevereiro de 1970, através do Decreto-Lei 195-A, as leis anteriores foram revogadas, e o Decreto passou a dispor sobre a proteção dos recursos hídricos contra agentes poluidores. Ele alterou a classificação das águas, estabelecendo os usos preponderantes como aspecto fundamental, dividindo-os em sete tipos, a saber:

1. Abastecimento doméstico;

2. Abastecimento industrial; 
3. Irrigação;

4. Preservação da flora e fauna;

5. Recreação;

6. Navegação;

7. Diluição de despejos.

Estabeleceu o Fomento Estadual de Saneamento Básico - FESB - como o órgão de controle da poluição das águas no Estado, e reiterou em seu Artigo 6ํㅡ a necessidade de "aprovação por parte dos órgãos competentes de projetos de instalação ou ampliação de estabelecimentos industriais e de loteamentos para efeito de cadastramento e controle da poluição das águas".

Em 31 de maio de 1976, foi editada a lei ํo 997, que dispõe sobre o controle da poluição do meio ambiente.

\subsubsection{A Tripla Licença}

A lei no 997/76 tem capital importância no controle da poluição no Estado de São Paulo e não se exagera quando se diz que também no Brasil.

Pela primeira vez no Estado, foram editadas normas específicas sobre o controle de poluição e ainda hoje, com os aprimoramentos necessários, têm sido aplicadas.

Em seu Artigo 5ํe estabeleceu a tripla licença como segue:

Artigo 5:: A instalação, a construção ou a ampliação, bem como a operação ou funcionamento das fontes de poluição que forem enumeradas no Regulamento desta Lei, ficam sujeitas à prévia autorização do órgão estadual de controle da poluição do meio ambiente, mediante expedição, quando for o caso, de Licença Ambiental Prévia (LAP), Licença Ambiental de Instalação (LAI) e/ou da Licença Ambiental de Operação (LAO). 
§1": Para os fins do disposto neste artigo, considera-se "fonte de poluição" qualquer atividade, sistema, processo, operação, maquinaria, equipamento ou dispositivo móvel ou não, previsto no Regulamento desta lei, que cause ou possa causar poluição ambiental através da emissão de poluentes.

§2: A Licença Ambiental Prévia - LAP será expedida na parte preliminar do planejamento de uma "fonte de poluição", conterá os requisitos básicos a serem atendidos nas fases de localização, instalação e operação e será outorgada por prazo determinado.

§3: A Licença Ambiental de Instalação - LAl autorizará o início da implantação, de acordo com as especificações constantes do projeto aprovado e será outorgada por prazo determinado.

§4: A Licença Ambiental de Operação - LAO autorizará o início da atividade licenciada e, quando couber, o funcionamento dos equipamentos de controle ambiental exigidos, de acordo com o previsto nas licenças ambientais prévia e de instalação e será outorgada por prazo determinado, sem prejuízo da eventual declaração de desconformidade do empreendimento ou atividade, do ponto de vista ambiental, ocorrida posteriormente, ensejando a adoção, pelo empreendedor, de medidas corretivas a serem implantadas de acordo com programas fixados pela autoridade competente.

O Decreto no 8468 de 8 de setembro de 1976 regulamentou a lei nำ 997/76 e em seu anexo A, no capitulo II, estabeleceu a competência da então Companhia Estadual de Tecnologia de Saneamento Básico e de Defesa do Meio Ambiente - CETESB como órgão delegado do Governo do Estado de São Paulo para a aplicação da lei no $997 / 76$.

Este decreto vem sendo aplicado e aprimorado constantemente, mas mantém inalterados os mecanismos de licenciamento, que, aliás, foram incorporados pela legislação federal - Lei no 6938/81.

Essa lei, que estabeleceu em nível nacional os instrumentos da política nacional do

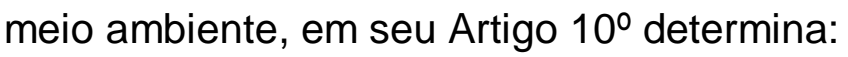


Artigo 10: A construção, instalação, ampliação e funcionamento de estabelecimentos e atividades utilizadoras de recursos ambientais, considerados efetiva ou potencialmente poluidores, bem como os capazes, sob qualquer forma de causar degradação ambiental, dependerão de prévio licenciamento por órgão estadual competente, integrante do SISNAMA, e do IBAMA, em caráter supletivo, sem prejuízo de outras licenças exigíveis.

Em 1986, isto é, cerca de cinco anos após a lei da política nacional do meio ambiente, o CONAMA, em sua primeira resolução 01/86, estabeleceu os critérios básicos e diretrizes gerais para o Relatório de Impacto Ambiental - RIMA instrumento fundamental para o licenciamento.

Somente em 1997, através da resolução CONAMA 237/97, foram regulamentados os aspectos do licenciamento ambiental, estabelecidos na política nacional de meio ambiente.

Através desses mecanismos legais, iniciados pela lei nº 997/76 e incorporados na legislação federal, ficou consolidado o sistema da tripla licença ambiental para os empreendimentos que utilizam os ativos ambientais.

\subsubsection{Entidades Licenciadoras}

\section{A) A Secretaria do Meio Ambiente}

Até o ano de 1989, o órgão central de controle ambiental no Estado de São Paulo, instituído pelo Decreto n 8468/76, era a CETESB. Com a estruturação da Secretaria Estadual do Meio Ambiente - SEMA, através do Decreto 30.555 de 03 de outubro de 1989, passou a ser de responsabilidade da SEMA, as atribuições do licenciamento das atividades efetiva ou potencialmente poluidoras, bem como as causadoras de degradação ambiental (Art.2ํㅡ - XVI).

Para atender a lei, a SEMA foi estruturada a partir da incorporação/agregação de vários órgãos pertencentes a outras instituições da administração pública, sem a devida compatibilização operacional necessária, fato este que dificultou a integração 
das ações de licenciamento, onde cada órgão aplicava sua legislação específica e atuava de acordo com sua esfera de atribuição. Desta forma, o licenciamento vinha se realizando de forma desarticulada, acarretando sérios problemas, valendo lembrar um dos mais críticos, quando um órgão se manifestava a favor da instalação de um empreendimento/atividade, enquanto o outro era obrigado a negar, por força da legislação por ele aplicada. Isto trazia sérias consequências à credibilidade do sistema perante seus usuários e principalmente, para o objeto de proteção pretendido.

A partir da estruturação da Secretaria, esta passou a licenciar os empreendimentos que exigiam a elaboração de EIA-RIMA, emitindo a Licença Prévia, cabendo à CETESB, a emissão das Licenças de Instalação e Operação (figura 5.3).

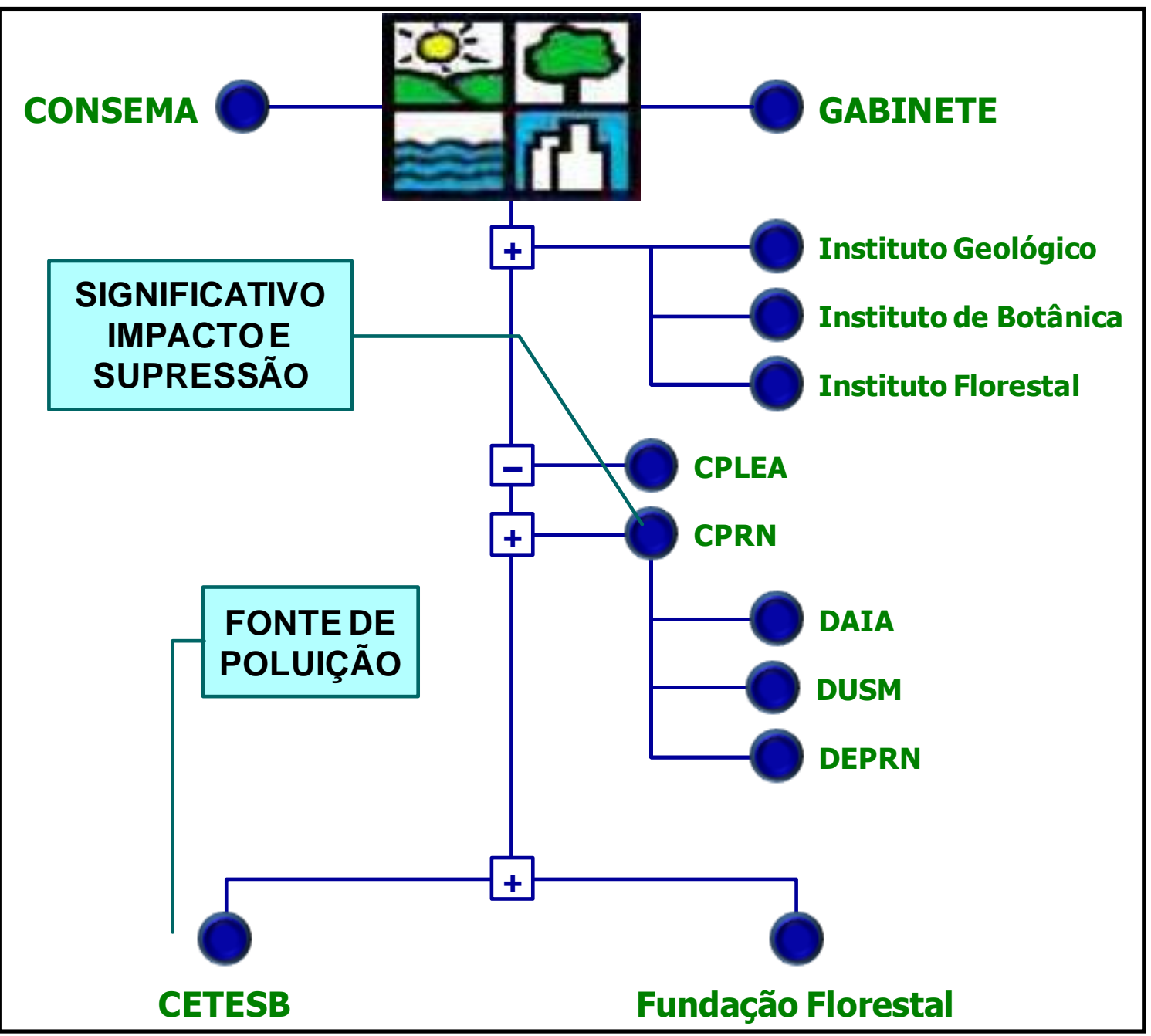

Figura 5.3 - Composição dos órgãos licenciadores da Secretaria de Meio Ambiente do Estado de São Paulo. Fonte: Minelli (2004) 
Foi estabelecido o fluxograma do licenciamento ambiental (figura 5.4), que passou a seguir os seguintes passos:

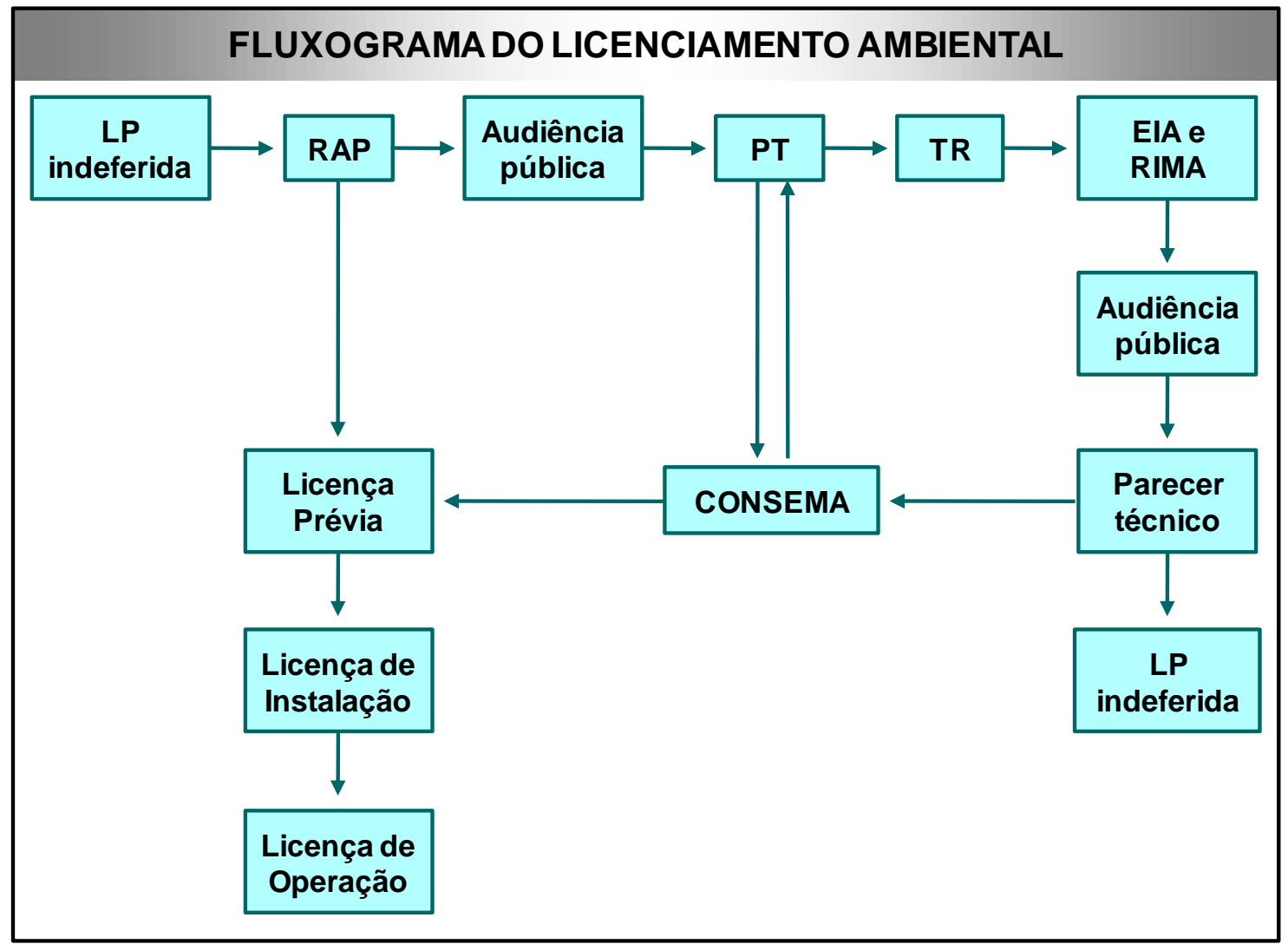

RAP: Relatório Ambiental Preliminar

PT: Plano de Trabalho

TR: Termo de Referência

EIA e RIMA: Estudo de Impacto Ambiental e Relatório de Impacto Ambiental CONSEMA: Conselho Estadual do meio Ambiente LP: Licença Prévia

Figura 5.4 - Fluxograma do licenciamento ambiental no Estado de São Paulo.

Fonte: STECH (2004)

Para os casos mais simples, das micro e pequenas empresas, que representam a grande maioria dos estabelecimentos industriais, onde não há necessidade de elaboração de EIA-RIMA, a CETESB tem autonomia para emitir as licenças LP, LI e LO, que obedecem as fases mostradas na figura 5.5 . 


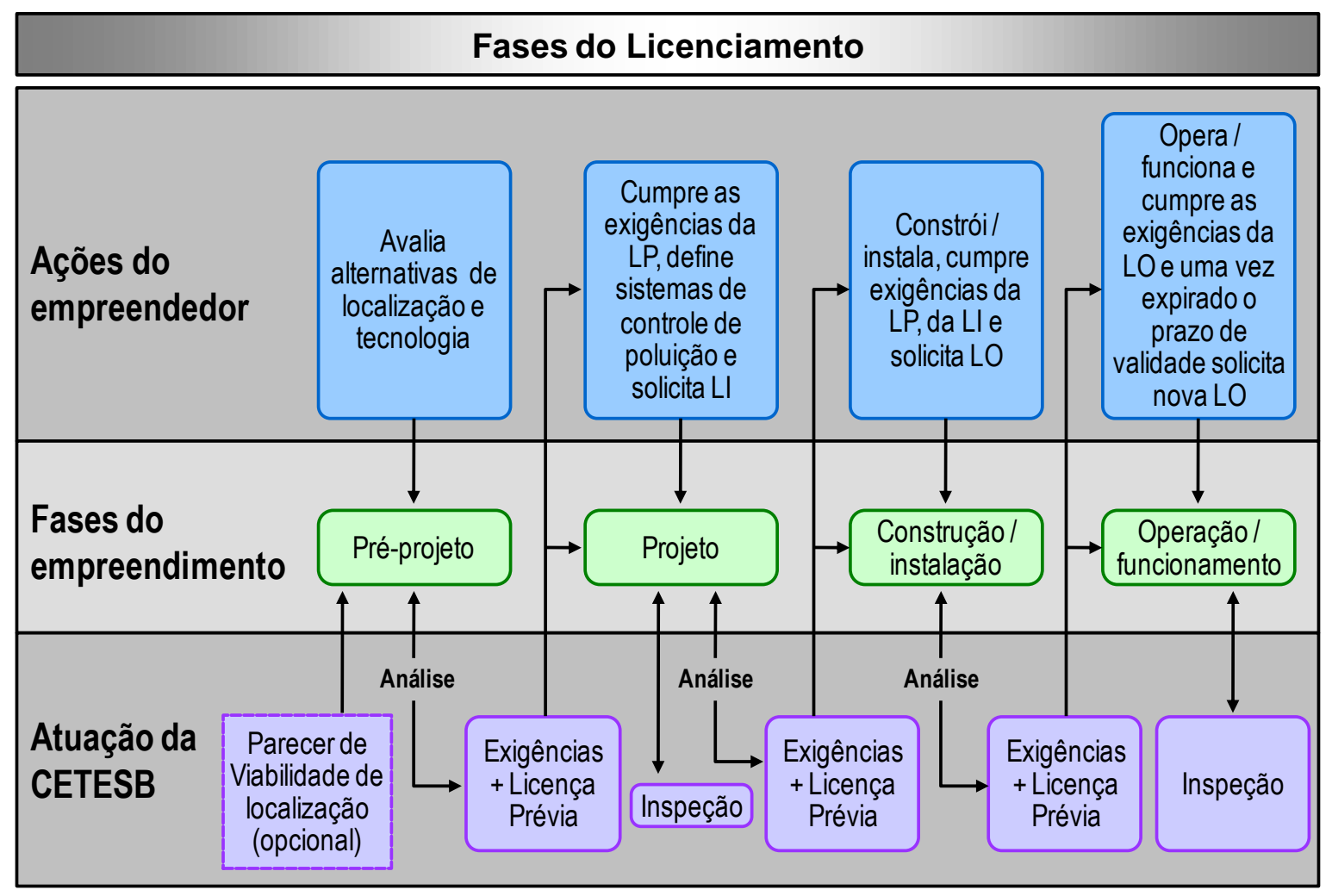

Figura 5.5 - Fases de licenciamento para micro e pequenas empresas no Estado de São Paulo. Fonte: FIESP-CETESB (2006)

Em intenso trabalho, objeto de financiamento do BIRD, o Ministério do Meio Ambiente elaborou o Plano Nacional do Meio Ambiente II, que deu origem ao excelente Diagnóstico da Gestão Ambiental nas Unidades da Federação, e no caso de São Paulo, a coleta de informações através das diversas fontes, permitiu elaborar o quadro funcional da Secretaria do Meio Ambiente (SMA), cuja síntese é mostrada na tabela 5.11. 
Tabela 5.11 - Síntese do número de funcionários envolvidos no licenciamento do Estado de São Paulo

\begin{tabular}{l|c|c|c}
\hline Instituição & Administrativos & Técnicos & Total \\
\hline SMA & 1654 & 642 & 2296 \\
\hline CETESB & 669 & 924 & 1593 \\
\hline Fundação Florestal & 91 & 278 & 369 \\
\hline TOTAL & 2414 & 1844 & 4258 \\
\hline
\end{tabular}

Fonte: MMA (2000)

Esse quadro funcional do sistema ambiental do Estado de São Paulo mostra, com clareza, a preponderância de funcionários administrativos (57\% do total) sobre os técnicos, os quais tinham, na época, 48.678 estabelecimentos industriais sob sua responsabilidade (IBGE, 2000).

Atualmente, no que se refere aos projetos mais complexos, que exigem EIA-RIMA para o seu licenciamento, verifica-se que a demanda para emissão de licenças ambientais não tem sido atendida de maneira adequada e nos tempos razoáveis.

Este fato implica em utilizar os artifícios da devolução dos projetos aos interessados para complementações repetitivas, quando na verdade, tais trabalhos já deveriam ter sido desenvolvidos nas fases anteriores e as eventuais complementações deveriam ter sido implementadas e ajustadas se os planos de trabalho tivessem sido desenvolvidos em conjunto empreendedor-agente público.

Para demonstrar tal fato, a figura 5.6 procura esclarecer as formas de procedimento, em que são mostradas as seis situações mais freqüentes no andamento dos processos, que foram acompanhados de maio de 2008 a junho de 2010, conforme publicações no diário oficial do Estado.

As situações mais freqüentes que ocorrem são:

- Aguardando Consema marcar audiência pública;

- Ouvir o comitê de bacia; 
- Ouvir agente externo (Ibama ou Instituto Florestal);

- Audiência pública;

- Aguardando as complementações do interessado;

- Em análise.

Existiam 1458 processos em andamento no intervalo de tempo avaliado. Destes, $33 \%$ aguardavam complementações dos interessados.

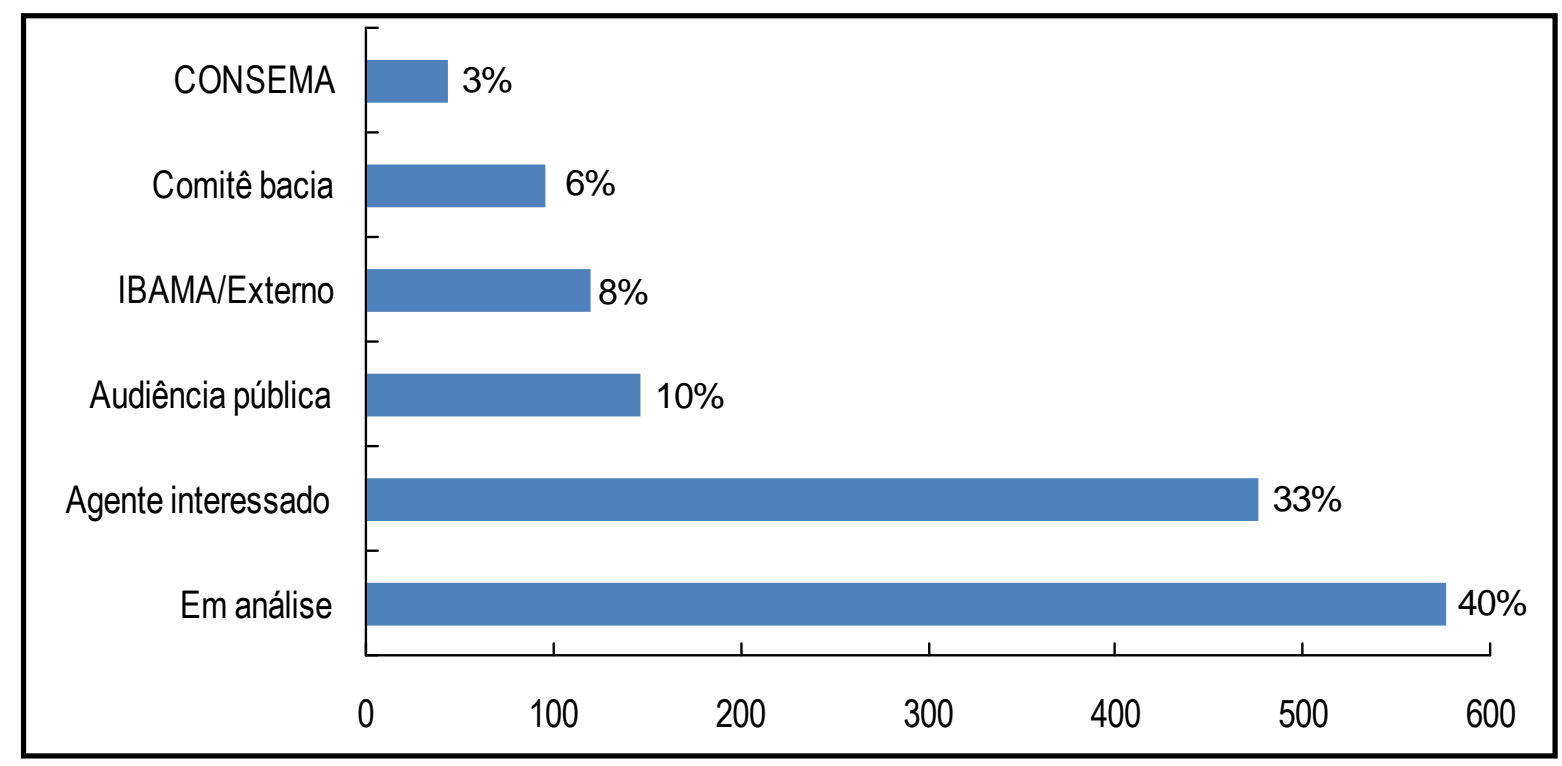

Figura 5.6 - Situação do licenciamento ambiental no Estado de São Paulo de maio de 2008 a junho de 2010. Fonte: Diário Oficial do Estado (2008/2010)

A alta incidência de devolução aos interessados pode indicar um procedimento administrativo protelatório para justificar os atrasos; pode também demonstrar o baixo padrão dos estudos; e ainda mostrar que houve trabalho insatisfatório na elaboração dos planos de trabalho e termos de referência.

\section{B) A CETESB}

A CETESB, exercendo o controle ambiental das fontes poluidoras do Estado de São Paulo, tinha uma demanda de solicitações de licenciamentos, que se expressam na tabela 5.12. 
Tabela 5.12 - Número de licenças emitidas pela CETESB de 2002 a 2008

\begin{tabular}{l|c|c|c|c|c|c|c}
\hline \multirow{2}{*}{ Tipo de licença } & \multicolumn{7}{|c}{ ANO } \\
\cline { 2 - 8 } & $\mathbf{2 0 0 2}$ & $\mathbf{2 0 0 3}$ & $\mathbf{2 0 0 4}$ & $\mathbf{2 0 0 5}$ & $\mathbf{2 0 0 6}$ & $\mathbf{2 0 0 7}$ & $\mathbf{2 0 0 8}$ \\
\hline Prévia & 276 & 6.452 & 8.757 & 9.761 & 8.863 & 7.974 & 2.427 \\
\hline Prévia e de Instalação & 0 & 0 & 0 & 0 & 0 & 0 & 5.916 \\
\hline Instalação & 7.938 & 7.533 & 8.915 & 9.690 & 8.913 & 7.941 & 2.337 \\
\hline Operação & 7.112 & 6.537 & 7.157 & 7.837 & 8.852 & 7.486 & 7.598 \\
\hline Operação a Título Precário & 1.726 & 1.969 & 2.056 & 1.970 & 1.856 & 1.615 & 1.567 \\
\hline Operação Renovação & 0 & 4 & 683 & 5.094 & 4.462 & 4.937 & 5.965 \\
\hline SILIS & 0 & 0 & 0 & 0 & 1.678 & 3.939 & 5.133 \\
\hline
\end{tabular}

Nota: SILIS - Sistema de Licenciamento Simplificado

Fonte: CETESB (2009)

Diferentemente da Secretaria do Meio Ambiente, a CETESB considera como fonte de poluição, cada unidade do processo produtivo que gera resíduos (por exemplo, um forno industrial) e cada dispositivo de controle de poluição (por exemplo, um lavador de gases) de um determinado empreendimento. Por esta razão, o número de licenças emitidas parece elevado e ele não representa o número de indústrias que se instalaram em uma determinada região; um empreendimento pode ter centenas de licenças, como no caso de indústrias petroquímicas. Portanto, não há uma visão integrada nem mesmo de um determinado empreendimento.

\subsubsection{A Judicialização do licenciamento}

A atuação do Ministério Público Estadual e Federal tem sido alvo de muitas críticas dos diversos setores envolvidos no processo.

Os promotores geralmente intervêm no processo de licenciamento quando acionados por ONGs; algumas com sérios propósitos na defesa do meio ambiente, outras atendem a interesses específicos, nem sempre relacionados com a defesa do meio ambiente. Muitas vezes, utilizam-se de técnicos dos próprios órgãos ambientais para fornecerem embasamentos aos laudos periciais, o que provoca um deslocamento dos técnicos das funções originais para absorverem essas demandas. 
Essa demanda tem sido quantificada e é mostrada na figura 5.6.

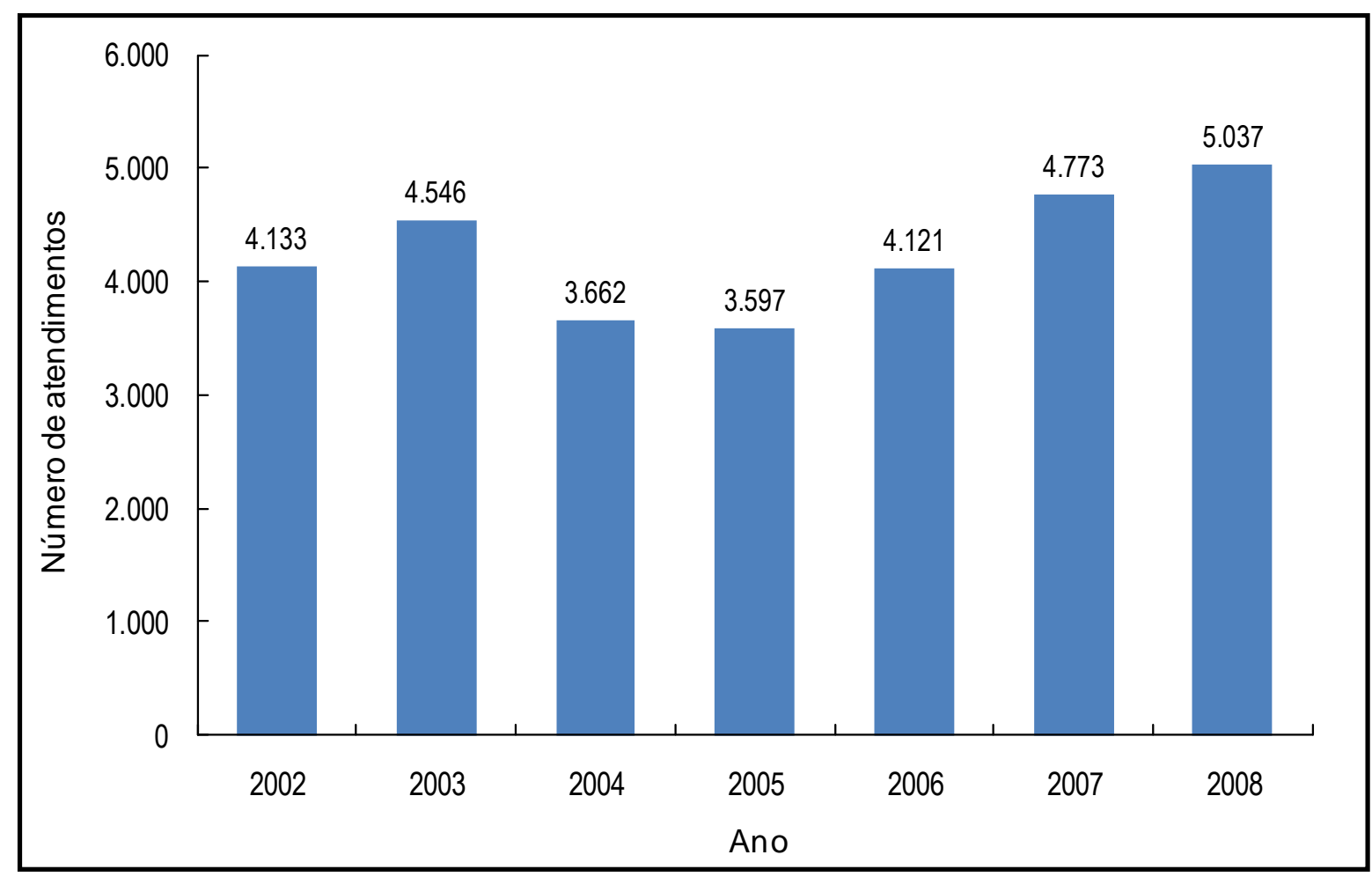

Figura 5.7 - Atendimentos da CETESB ao Ministério Público de 2002 a 2008.

Fonte: CETESB (2009)

Embora tais atendimentos representem um número significativo, não devem representar obstáculos para interferir no processo de licenciamento.

A atuação que tem sido bastante questionada pelos agentes ambientais é representada pelo número de ações impetradas pelo Ministério Público no exercício do seu dever constitucional de defender a sociedade e os direitos indisponíveis. Essas ações muitas vezes são vistas como ameaças ao desempenho funcional e provocam uma atuação defensiva dos agentes públicos, entendimento que nem sempre é compartilhado pelo Ministério Público.

De fato, os promotores têm sido atuantes na sua responsabilidade de provocar o Poder Judiciário para definir as pendências que, no seu entender, estão contrariando as leis (Tabela 5.13). 
Esse fato tem ocorrido em todo o Brasil e, se de um lado representam o interesse da sociedade nas questões ambientais, não raro representam interesses peculiares que são levados ao MP como "grandes questões ambientais", o que nem sempre se configura como adequado.

Tabela 5.13 - Número de inquéritos e ações civis públicas impetradas pelo Ministério Público Estadual

\begin{tabular}{l|c|c|c}
\hline Ano & № Inquéritos & № Ações Civis Públicas impetradas & Maior Incidência (\%) \\
\hline 2004 & 3.135 & 147 & $42-$ Flora \\
\hline 2005 & 3.536 & 257 & $43-$ Flora \\
\hline 2006 & 3.739 & 294 & 57 - Flora \\
\hline 2007 & 4.280 & 486 & 68 - Flora \\
\hline 2008 & 4.462 & 306 & 56 - Flora \\
\hline Total & 19.152 & 1.490 & \\
\hline
\end{tabular}

Flora: Queima da palha de cana e supressão de vegetação, etc.

Fonte: CAO-MPE,(2009)

Em âmbito nacional, também ocorre o mesmo fenômeno, tendo o Ministério Público Federal atuado com zelo e rigor, ainda que muitas vezes induzido de maneira inadequada (Tabela 5.14).

Tabela 5.14 - Número de ações impetradas pelo Ministério Público Federal

\begin{tabular}{|c|c|c|c|}
\hline Região & 1a Instância & 2ª Instância & Relação 2a/1 \\
\hline SP/MS & 2130 & 548 & 24,3 \\
\hline RS/SC/PR & 467 & 156 & 33,4 \\
\hline RO & 3820 & \multirow{6}{*}{1533} & \multirow{6}{*}{9,3} \\
\hline AM & 2620 & & \\
\hline PA & 4367 & & \\
\hline MG & 2817 & & \\
\hline DF & 1404 & & \\
\hline MT & 1378 & & \\
\hline
\end{tabular}

Fonte: MONTEZUMA,T (2007) 
Verifica-se que na Justiça Estadual, dos 19.152 procedimentos investigativos, somente 1490, isto é, 7,8\% geraram ações, e na Justiça Federal na Região de São Paulo e Mato Grosso do Sul, somente $24 \%$ se encaminharam para julgamento em $2^{\text {a }}$ Instância.

Ainda que em número aparentemente reduzido, essas ações associadas com as ameaças de aplicação da lei n 9605/98, a chamada lei de crimes ambientais, têm inibido fortemente a liberação de licenças, pois o agente público fica sujeito à discricionariedade do promotor de justiça, que nem sempre é assessorado adequadamente e/ou com propósitos adequados.

Muitas vezes, com o grande apelo popular e apoio da mídia, fica difícil ao promotor resistir à atração do proscênio, no entanto a experiência tem mostrado que o poder judiciário na sua função de moderador e com o poder da decisão final tem agido com serenidade e restabelecido às condições adequadas do projeto, buscando o equilíbrio entre o desenvolvimento e a sustentabilidade.

\subsubsection{A Atuação das ONGs}

O meio ambiente, bem comum de todos, exige uma intensa e responsável participação da sociedade.

As audiências públicas, necessárias e obrigatórias como parte do processo de licenciamento de atividades modificadoras do meio ambiente, têm sido a forma de manifestação da vontade da sociedade civil organizada.

Assim tem ocorrido em todos os lugares do mundo.

As comunidades interessadas têm se organizado em torno de organizações civis não governamentais, com legitimidade para defender aspectos das comunidades perante os agentes governamentais.

Muitas dessas organizações têm desempenhado papel importante e significativo na formulação de políticas de defesa do meio ambiente e participado dos colegiados 
que ditam as normas técnicas e definem alterações nos projetos, apresentando alternativas para os empreendedores. Algumas, de âmbito nacional, têm até legitimidade para pleitearem alterações constitucionais.

Várias dessas ONGs contam com corpo técnico respeitável, que tem apresentado boas contribuições, outras se restringem a defender interesses setoriais e específicos, nem sempre motivadas pela melhor intenção.

Apareceram de início como organizações que representavam grupos de interesse das comunidades, hoje, muitas estão se transformando em defensoras de interesses de grupos empresariais com poder econômico de porte e têm introduzido nos processos ambientais, distorções para as quais o Poder Público deve estar atento, procurando identificar os reais objetivos de atuação.

\subsubsection{Análise do Plano Nacional do Meio Ambiente - PNMA II}

O Plano Nacional do Meio Ambiente II (MMA, 2000) fez um amplo e detalhado levantamento do sistema de licenciamento ambiental no Estado de São Paulo, mas não foi feita uma análise dos dados obtidos. Segue esta análise e as principais conlusões:

\section{A) Em termos de Recursos Humanos:}

Tanto no Departamento Estadual de Proteção de Recursos Naturais (DEPRN) quanto no Departamento de Uso e Ocupação do Solo em Áreas de Mananciais (DUSM) e na CETESB, havia vários desvios de função. Podem ser citados os seguintes casos:

\section{No DEPRN:}

- Assessor executivo da Diretoria Administrativa era formado em Letras;

- Diretor Técnico de Serviço era artista plástico;

- Oficial administrativo era comunicólogo; 
- Pesquisador científico tinha apenas $2^{\circ}$ grau;

- Analista administrativo financeiro contábil era engenheiro florestal;

- Chefe de seção da Diretoria Geral era formado em letras;

- Auxiliar administrativo financeiro era formado em História;

- Oficial administrativo era biólogo;

- Auxiliar administrativo contábil e financeiro era formado em letras;

- Assistente Administrativo da unidade da RMSP era geógrafo.

No DUSM:

- Chefe de serviço administrativo era formado em educação física.

Na CETESB:

- As agências de Santana, Pinheiros, Campinas, Paulínia e Limeira possuíam um número excessivo de educadores ambientais.

- Havia administradores, advogados, arquitetos, técnicos em processamento de dados, biomédicos, profissionais formados em ciências - licenciatura para o $1^{\circ}$ grau e zootecnistas fiscalizando e analisando processos de licenciamento

Os dados mostraram, também, que os funcionários do órgão ambiental realizavam um elevado número de cursos/treinamentos em áreas não prioritárias, tais como participação nos Seminários Nacionais de Aposentadoria e nos cursos "Procedimentos para Classificação Fiscal de Mercadorias" e "Auditoria Médica e de Enfermagem", entre outros.

B) Infra-estrutura

- Os equipamentos do Laboratório, principalmente os da Diretoria de Controle da Poluição Ambiental eram muito antigos e obsoletos; 
- O número de veículos era insuficiente e muitos possuíam um tempo de uso superior a dez anos;

- Nem todos os agentes ambientais possuíam microcomputadores.

C) Aspectos institucionais

- Faltava articulação entre a SMA e a CETESB. O Departamento de Avaliação de Impactos Ambientais (DAIA) da SMA fazia as exigências na licença e a CETESB realizava a inspeção e a fiscalização. Como os técnicos do DAIA não faziam a inspeção, as exigências, muitas vezes, eram inexequíveis no local da implantação do empreendimento;

- Incompatibilidade entre órgãos de outorga de água e de licenciamento e fiscalização para os empreendimentos que utilizavam recursos hídricos;

- A ISO 14.001 deveria levar em consideração as informações dos órgãos ambientais.

D) Tempos para o licenciamento

O processo para concessão da licença era demasiadamente longo:

- DAIA: 1 ano

- DUSM: 60 dias

- CETESB: 30 dias

- Balcão Único: 60 dias

- Grupo de Análise e Aprovação de Projetos Habitacionais do Estado de São Paulo (GRAPROHAB): 60 dias

Os órgãos licenciadores forneciam muito prazo ao empreendedor para entrega das complementações:

- DEPRN: variável 
- DAIA: 2 meses

- DUSM: 60 dias

- CETESB: 15 a 30 dias

- GRAPROHAB: 60 dias

\section{E) Aspectos financeiros}

Poucas multas eram pagas e, portanto, não havia sustentabilidade financeira no sistema de licenciamento ambiental:

- Custo médio da licença em 1999:

$R \$ 1.548,00$

- Valor total das multas aplicadas pela CETESB em 1999:

$R \$ 405.836 .000,00$

- Receita recebida pela CETESB devido às multas em 1999:

$R \$ 152.216 .000,00$ (37,5\% do total)

- Receita de multa arrecadada pelo DEPRN/PFM em 1999:

$R \$ 1.754 .502,49$

F) Baixa qualidade dos relatórios entregues pelo empreendedor

Por exemplo, em 1999, dos 638 planos de Recuperação de Áreas Degradadas, apenas $40 \%$ foram aprovados.

G) Dificuldade de obtenção dos dados necessários para a análise de possibilidade de licenciamento

No estágio de desenvolvimento das organizações governamentais, as informações eram percebidas como pertencentes aos indivíduos que as manipulavam, constituindo-se em fontes de poder pessoal, provocando o fenômeno conhecido na teoria da administração como "ilhas de informação". 


\subsubsection{Reestruturação do Sistema}

A) Decretos $n^{0} .47 .397 / 02$ e $n^{0} .53 .205 / 08$

Em 4 de dezembro de 2002, foi publicado o Decreto $n^{\circ} .47 .397$, que alterou o título $V$ e o Anexo 5 e acrescentou os Anexos 9 e 10 ao Decreto $n^{\circ}$. 8.468/76. Em 3 de julho de 2008, novas alterações foram feitas através do Decreto $n^{\circ}$. 53.205.

Os seguintes artigos e anexos do Decreto 43.397/02 devem ser destacados para aprofundamento das análises:

\section{Artigo 57}

Em relação ao Decreto original (Decreto no. 8.468/76), foram inseridas as seguintes fontes de poluição:

- Hospitais veterinários;

- Serviços de coleta, armazenamento, transporte e disposição final de lodos ou materiais retidos em unidades de tratamento de água, esgoto ou de resíduos industriais;

- Cemitérios horizontais ou verticais;

- Elevatórias e disposição final de esgotos;

- Comércio varejista de combustíveis automotivos, incluindo postos revendedores, postos de abastecimento, transportadores revendedores retalhistas e postos flutuantes;

- Termelétricas ou co-geradoras de energia e

- Estações de Tratamento de Água.

Por outro lado, a agroindústria, responsável pela emissão de cargas difusas de pesticidas, nitrogênio e fósforo e os laboratórios, que geram resíduos sólidos, líquidos e gasosos perigosos, não foram contemplados.

Como mencionado anteriormente, a CETESB deve licenciar "os serviços de coleta, armazenamento, transporte e disposição final de lodos ou materiais retidos em 
unidades de tratamento de água, esgotos ou de resíduos industriais". Portanto, no caso de uso de lodo gerado em estações de tratamento de esgoto em unidades agrícolas, o órgão ambiental paulista tem que licenciá-las. Assim, os agricultores, que aceitarem utilizar o lodo, dando-Ihe um destino ambientalmente adequado, serão penalizados, uma vez que terão que arcar com os custos do licenciamento e atender às exigências ambientais da licença, obrigatoriedade que outros não terão, pois, a CETESB não licencia atividades agropastoris.

Em nenhum lugar no mundo, faz-se o licenciamento de estações elevatórias. A efetividade do licenciamento destas instalações é altamente questionável e esta tarefa consome muito tempo, que poderia ser melhor empregado pelos agentes ambientais em atividades de prevenção e controle da poluição comprovadamente mais eficientes e eficazes.

Foram incluídas neste artigo, atividades de impacto local, tais como fabricação de acessórios do vestuário; de artefatos de pastas, papel, papelão, cartolina e cartão para escritório; de colchões, sem espumação; de escovas, pincéis e vassouras; de fitas e formulários contínuos; impressão de material para uso escolar e de material para usos industrial, comercial e publicitário. Embora estas atividades possam ser licenciadas pelo município, este só pode fazê-lo quando possuir um Conselho Municipal de Meio Ambiente, um quadro de profissionais habilitados e uma legislação ambiental específica e em vigor. Caso contrário, a CETESB, que constantemente se ressente do reduzido número de funcionários, deverá licenciar tais atividades. Ela deveria priorizar o licenciamento de atividades de significativo impacto ambiental.

\section{Anexo 1}

O anexo 1, que substitui o Anexo 5 do Decreto $\mathrm{n}^{\circ}$. 8468/76, descreve com muitos detalhes as atividades a serem licenciadas pela CETESB, o que dificulta a compreensão do empreendedor. Por exemplo, no caso de uma indústria têxtil, que faz a fiação, a tecelagem, a estamparia, o alvejamento e o tingimento, não está claro como se calcula o preço da licença, uma vez que os valores de w são diferentes para cada uma destas etapas e o preço da licença é calculado pela fórmula: 


$$
P=70+(1,5 \cdot w \cdot \sqrt{A})
$$

onde:

$\mathrm{P}=$ preço a ser cobrado, expresso em UFESP

$\mathrm{w}=$ fator de complexidade, de acordo com o anexo 5 do Decreto

$\sqrt{ } A=$ raiz quadrada da área integral da fonte de poluição objeto do licenciamento.

Há ainda inconsistências no valor de w, tais como:

- A produção de sucos de frutas e legumes $(w=2,5)$, bem como o processamento, preservação e produção de conservas de frutas e de legumes $(w=2,0)$ são tão poluentes quanto à fabricação de sorvetes, cujo valor de w é 3,0 .

- Fabricação de pisos gera efluentes líquidos e resíduos sólidos contendo metais pesados e efluentes gasosos contendo grande quantidade de material particulado e fluoretos. $O$ fator $w$ igual a 2,0 está muito baixo.

- A fabricação de armas de fogo, munições e equipamentos militares produzem compostos nitrogenados altamente tóxicos. O valor de $\mathrm{w}$ igual a 2,5 é baixo.

\section{Artigo 60}

Embora estivesse mencionado no Decreto $n^{\circ}$. 8468/76 que "não será expedida licença de instalação quando houver indícios ou evidências de que ocorrerá o lançamento ou liberação de poluentes nas águas, no ar ou no solo", esta frase deveria ter sido corrigida no Decreto $47.397 / 02$ ou na sua alteração, Decreto no . 53.205/08, pois nem aplicando a melhor tecnologia de controle da poluição, consegue-se emissão zero. Portanto, sempre existirão indícios e evidências do lançamento de poluentes.

No caso de loteamento ou desmembramento de imóveis, condomínios horizontais ou verticais e conjuntos habitacionais, o empreendedor deverá comprovar que a área objeto de licenciamento não apresenta impedimentos à ocupação proposta sob o ponto de vista ambiental e de saúde pública. Esta imposição é adequada para o 
caso de condomínios ou conjuntos habitacionais, no entanto, é inviável para pequenos lotes.

\section{Artigo 61}

Assim como o empreendedor é punido por não requerer a licença ambiental, a CETESB não poderia exigir o licenciamento para a obtenção da inscrição estadual se ela não conseguir cumprir o prazo estipulado de 30 dias para a emissão da mesma. No decreto, está escrito “...findo o prazo fixado de 30 dias, sem manifestação da CETESB, a Secretaria da Fazenda poderá fornecer a Inscrição Estadual, independentemente da apresentação da referida licença”, o que pressupõe a priori que a CETESB não cumprirá o prazo.

\section{Artigo 67}

A compatibilidade do empreendimento com o zoneamento estabelecido para o local, assim como a sua compatibilidade com a ocupação do solo circunvizinho não são atribuições da CETESB e, portanto, não é ela que deve avaliar este aspecto.

\section{Artigo 71}

Não há justificativa para que não se renove as licenças de operação relativas aos loteamentos, desmembramentos, condomínios e conjuntos habitacionais e os cemitérios.

\section{Artigo 73}

O preço da licença é extremamente alto para serviços de utilidade pública, tais como estações de tratamento de água (ETA) e de esgoto (ETE) e hospitais.

Por exemplo, para a ampliação da ETA Taiaçupeba, cujo custo foi de $R \$$ 53.000.000,00, a concessionária de saneamento e em última análise, a sociedade teve que desembolsar $R \$ 530.000,00$ para obtenção das licenças de instalação e 
operação. A cada cinco anos, a concessionária deverá pagar $R \$ 132.500,00$ para renovação da licença de operação. Para uma Estação de Tratamento de Esgoto como a do Parque Novo Mundo, cujo custo foi de $R \$ 125.155 .000,00$, o valor a ser pago para obter as duas licenças (instalação e operação) será de $R \$ 1.251 .550,00$ e para renová-las, $\mathrm{R} \$ 312.887,50$ a cada três anos.

Para o licenciamento ambiental de um hospital público como o das Clínicas, que possui 352 mil metros quadrados, a sociedade terá que pagar aproximadamente $R \$$ $11.304,00$ na licença prévia; $R \$ 37.682,00$ na licença de instalação; igual valor na licença de operação e $R \$ 18.841,00$ para a renovação, que deve ser feita a cada quatro anos.

Por outro lado, uma indústria altamente poluidora e que possua uma área de $250.000 \mathrm{~m}^{2}$ pagará $R \$ 18.817,32$ para obtenção da licença prévia, $R \$ 62.724,40$ para a de instalação e igual valor para a de operação. Deverá renovar sua licença a cada dois anos.

\section{Artigo 74}

Uma vez que há o instrumento da licença prévia, deveria ser abolido o parecer de viabilidade de localização, cujo custo é de 100 UFESP.

O órgão ambiental paulista cobra 70 UFESP pelo Certificado de Aprovação Destinação de Resíduos Industriais, no entanto, praticamente não existe fiscalização sobre o transporte de resíduos.

\section{Anexo 2}

É incoerente deixar a critério do município o licenciamento de atividades cujo fator de complexidade é 3,0 , que denota alto potencial poluidor. 
B) Decretos $n^{\circ} 47.400 / 02$ e $n^{\circ} 55.149 / 09$

Decreto $n^{\circ} 55.149$ de 10 de dezembro de 2009 deu nova redação aos dispositivos do Decreto $n^{0} 47.400$, de 4 de dezembro de 2002, que regulamentou a lei estadual no 9.509 no que se refere ao licenciamento ambiental. Ao contrário do que preconiza a lei ${ }^{3}$, que previa um licenciamento unificado, o decreto mostra a fragmentação e a conseqüente fragilidade do Sistema Ambiental do Estado de São Paulo, enfatizando as diferenças de procedimentos de licenciamento empregadas para o caso dos empreendimentos listados na Resolução CONAMA n ${ }^{\circ} 237 / 97$ e aqueles listados no Decreto $n^{\circ} 8.468 / 1976$ e suas alterações (Decreto $n^{\circ} 47.397 / 2002$ e Decreto $n^{0}$ 53.205/2008). Os prazos de validade das licenças emitidas nos dois casos são distintos, a saber (Tabela 5.15).

Tabela 5.15 - Prazos de validade das licenças estipulados pelos Decretos $n^{\circ}$ $47.397 / 2002$ e $n^{\circ} 53.205 / 2008$ e pelos Decretos $n^{\circ} 47.400 / 02$ e $n^{\circ}$ $55.149 / 09$

\begin{tabular}{l|c|c}
\hline \multirow{2}{*}{ Licença } & \multicolumn{2}{|c}{ Prazos máximos de validade das licenças } \\
\cline { 2 - 3 } & $\begin{array}{c}\text { Decretos } \mathbf{n}^{\circ} \mathbf{4 7 . 3 9 7 / 0 2} \mathrm{e} \\
\mathrm{n}^{\circ} \mathbf{5 3 . 2 0 5 / 2 0 0 8}\end{array}$ & $\begin{array}{c}\text { Decretos } \mathbf{n}^{\circ} \mathbf{4 7 . 4 0 0 / 0 2} \mathrm{e} \\
\mathbf{n}^{\circ} \mathbf{5 5 . 1 4 9 / 0 9}\end{array}$ \\
\hline Prévia & 2 anos & 5 anos \\
\hline De Instalação & $\begin{array}{c}\text { 3 anos, exceto em } \\
\text { parcelamentos, sendo a validade } \\
\text { nestes casos de 2 anos }\end{array}$ & 6 anos \\
\hline De operação & 5 anos & 10 anos \\
\hline
\end{tabular}

\footnotetext{
${ }^{3}$ Artigo 6ำ- O Sistema Estadual de Administração da Qualidade Ambiental, Proteção, Controle e Desenvolvimento do Meio Ambiente e Uso Adequado dos Recursos Naturais - SEAQUA, tem por objetivo organizar, coordenar e integrar as ações de órgãos e entidades da administração direta, indireta e fundacional instituídas pelo poder público, assegurada a participação da coletividade, para a execução da Política Estadual do Meio Ambiente visando à proteção, controle e desenvolvimento do meio ambiente e uso sustentável dos recursos naturais, nos termos do artigo 193 da Constituição do Estado.
} 
Os Decretos $n^{0} 47.400 / 02$ e $n^{0} 55.149 / 09$ estabeleceram prazos de validade das licenças, no entanto, “...a CETESB poderá, mediante decisão motivada, manter, ampliar ou diminuir o prazo de validade, mediante avaliação do desempenho ambiental do empreendimento ou atividade no período de vigência anterior" e "...os empreendimentos ou atividades que, por ocasião da renovação de suas licenças de operação, comprovarem a eficiência dos seus sistemas de gestão e auditoria ambientais, poderão ter o prazo de validade da nova licença ampliado, em até um terço do prazo anteriormente concedido, a critério da CETESB". Portanto, o prazo de validade pode ser alterado pela CETESB, o que não está previsto no Decreto $\mathrm{n}^{\circ}$ 47.397/02. Deve-se salientar, ainda, que a existência de sistemas de gestão e auditorias ambientais não garante que a empresa seja ambientalmente adequada. Muitas vezes, os organismos certificadores nem verificam se o empreendimento tem pendências com o órgão ambiental.

Segundo os decretos, os preços para análises necessárias à expedição das licenças ambientais pela CETESB serão cobrados separadamente do empreendedor, que deverá recolher ao Fundo Especial de Despesa da Coordenadoria de Biodiversidade e Recursos Naturais ou ao Fundo Especial de Despesa do Instituto Florestal da Secretaria de Meio Ambiente ou à CETESB, conforme a competência dos órgãos que devam manifestar-se no procedimento de licenciamento. Portanto, empreendimentos que dependam da análise de todos estes órgãos deverão pagar a cada um deles em locais separados para obter uma licença única do sistema ambiental. Tal procedimento é contrário à diretriz do governo estadual de desburocratizar e facilitar a emissão de documentos.

Em se tratando de serviços de utilidade pública, tais como hospitais, sistemas de abastecimento de água e de esgoto, cujo licenciamento depende normalmente de estudo de impacto ambiental, o custo será muito alto. No exemplo da ETE dado anteriormente, a concessionária de saneamento deveria pagar além dos $\mathrm{R} \$ 1.251 .550,00$ para obter as licenças de instalação e operação (se as licenças prévia e de instalação forem solicitadas concomitantemente), os custos decorrentes da análise do EIA/RIMA ( $R \$ 9.315,00)$ e dos pareceres para análise de intervenções em áreas de proteção aos mananciais $(R \$ 248,40)$. 
C) Lei $13.507 / 09$

A Lei 13.507 de 23 de abril de 2009 estabeleceu novas e relevantes funções para o Conselho Estadual do Meio Ambiente, enfatizando nele as funções constitucionais de órgão consultivo, normativo e recursal do Sistema Estadual de Administração da Qualidade Ambiental, Proteção, Controle e Desenvolvimento do Meio Ambiente e Uso Adequados dos Recursos Naturais - SEAQUA.

Enquanto nas condições anteriores, as LPs somente eram concedidas após audiência no CONSEMA, por essa lei, em seu Artigo $2^{\circ}$ - VI, "apreciar Estudos de Impacto Ambiental - EIA e seus respectivos Relatórios de Impacto sobre o Meio Ambiente - RIMA, por solicitação do Secretário do Meio Ambiente ou por decisão do Plenário, mediante requerimento de um quarto de seus membros".

O CONSEMA é um colegiado constituído por 36 membros, sendo 18 representantes de entidades não governamentais e 6 eleitos por entidades ambientalistas (Art. $7^{\circ}$ I, II, e III).

Antes dessa lei bastava ao CONSEMA avocar por qualquer de seus membros, e sempre o fazia, os EIA-RIMA passavam a ser analisados por câmaras técnicas, eram debatidos em plenário que não tem capacitação técnica para tal, e servia de instrumento para postergar prazos. Não raro os debates politizados se estendiam longo tempo.

\section{D) Lei $13.542 / 09$}

A lei 13.542 de 8 de maio de 2009 alterou a lei 118 de 29 de junho de 1973 - de criação da CETESB, modificando sua denominação e estabeleceu mudança significativa nos procedimentos de licenciamento ambiental.

Por ela, a CETESB deixa de ser Companhia de Tecnologia de Saneamento Ambiental e passa a denominar-se Companhia Ambiental do Estado de São Paulo (Art. 1ㅇ).

A alteração fundamental ocorre no Art.2o - I - redigido nos seguintes termos: 
"proceder ao licenciamento ambiental de estabelecimentos e atividades poluidoras, bem como capazes, sob qualquer forma, de causar degradação ambiental;"

Estabelece a competência concorrente entre a CETESB e a Secretaria do Meio Ambiente no seu parágrafo primeiro que assim se expressa:

$\$ 1^{\circ} \mathrm{O}$ exercício, pela CETESB, das atribuições definidas neste artigo

1. não exclui a competência de outros órgãos da Secretaria do Meio Ambiente e dos demais órgãos integrantes do SEAQUA e do SIGRH, especialmente na fiscalização preventiva e repressiva de infrações à legislação ambiental, de proteção dos mananciais e do cumprimento de condicionantes de licenças e autorizações ambientais."

Segundo a CETESB, os objetivos dessa nova legislação estão inseridos no Projeto Estratégico do Licenciamento Ambiental Unificado e consubstanciados nos seguintes pontos:

- Unificar o licenciamento ambiental;

- Desburocratizar o serviço;

- Atuar com mais rigor, agilidade e transparência;

- Capacitar os municípios para assumir o licenciamento de empreendimentos de impacto local.

E o resultado esperado é a redução dos tempos do licenciamento em $30 \%$. Se este de fato for atingido, sem dúvida, se terá dado um passo na direção adequada e exigida pela sociedade.

Não será sem tempo o advento dessas modificações e a explicitação desses propósitos, pois os exagerados prazos que têm sido despendidos nos processos de licenciamento levam enormes alterações nos custos dos empreendimentos.

Para empreendimentos de geração termoelétricos de médio porte, no Estado de São Paulo, Aguilar (2008), concluiu que os tempos médios para aprovação do EIA-RIMA variaram de 400 a 600 dias. 
Agregando-se aos dados as informações dos tempos para o licenciamento do setor elétrico, conforme levantamento feito pelo Banco Mundial, e dois parâmetros do Rodoanel de São Paulo, verifica-se que os tempos médios para licenciamento ambiental para empreendimentos de obras de infra-estrutura não são inferiores a três anos, na melhor das hipóteses.

Este fato introduz grandes custos adicionais aos empreendimentos e por conseqüência, nos ajustes tarifários deles decorrentes. Em última análise, é a população quem paga por esta ineficiência.

Não se alegue que a um maior tempo corresponde um maior rigor na análise ou proteção mais adequada ao meio ambiente. Trata-se única e exclusivamente de deficiência de gestão ou discricionariedade nos procedimentos com finalidades pouco claras.

O exemplo do Rodoanel Mario Covas em São Paulo é significativo. É inquestionável para a Região Metropolitana de São Paulo, do ponto de vista ambiental, a importância do empreendimento. No entanto, após cumprir todas as etapas para a obtenção da LP, o empreendedor se depara ainda com a necessidade de obtenção da LI.

O relatório ambiental, que embasou a LP, com 250 páginas, assim citou:

"Para a obtenção da Licença de Instalação, o DERSA deveria atender a todas as medidas já propostas no EIA e no RIMA além de 116 exigências adicionais."

E prossegue o citado relatório:

"Após demonstrar o adequado atendimento a todas as condicionantes e exigências, foram emitidas 14 Licenças de Instalação, com 116 condicionantes e 26 programas. As 116 condicionantes foram agrupadas em 78 por semelhança, sendo que deste total, $72 \%$ já foram cumpridas"

As obras do Rodoanel estavam estimadas em $\mathrm{R} \$ 2.600$ Milhões, e para atender as exigências formuladas, o valor estimado representou $7,31 \%$ do custo total do empreendimento. O tempo de tramitação do licenciamento foi de 5,9 anos e as obras tinham o seu cronograma estabelecido em 3,8 anos. 
Fica evidente a prevalência das questões burocráticas ao invés da eficiência de gestão; o número e a natureza das exigências demonstram uma total insensibilidade quanto à gestão dos recursos públicos, que sem dúvida, estarão refletidos nas tarifas de circulação dos veículos por essa via.

Melhor teria sido já na fase da LP, a formatação de um programa de ação, incorporado ao EIA-RIMA, tornando os custos mais previsíveis.

\subsubsection{A tramitação dos processos durante reestruturação do sistema}

A ineficiência de gestão fica evidente quando se analisa o andamento dos processos dos EIA-RIMA, passo primeiro e indispensável para a emissão da LP.

Quarenta por cento dos processos são devolvidos para os interessados fazerem complementações, isto significa que ou o termo de referência foi inadequado ou o plano de trabalho para a elaboração do EIA-RIMA foi analisado de forma superficial.

A resolução SMA 19 de 09/10/1991 e SMA 66 de 17/12/96 determinam a publicação no Diário Oficial do Estado da relação dos processos de aprovação de EIA-RIMA protocolados na SMA.

A tramitação desses processos foi acompanhada por um período de cerca de dois anos, e permitiu elaborar o gráfico, mostrado na figura 5.7 . 


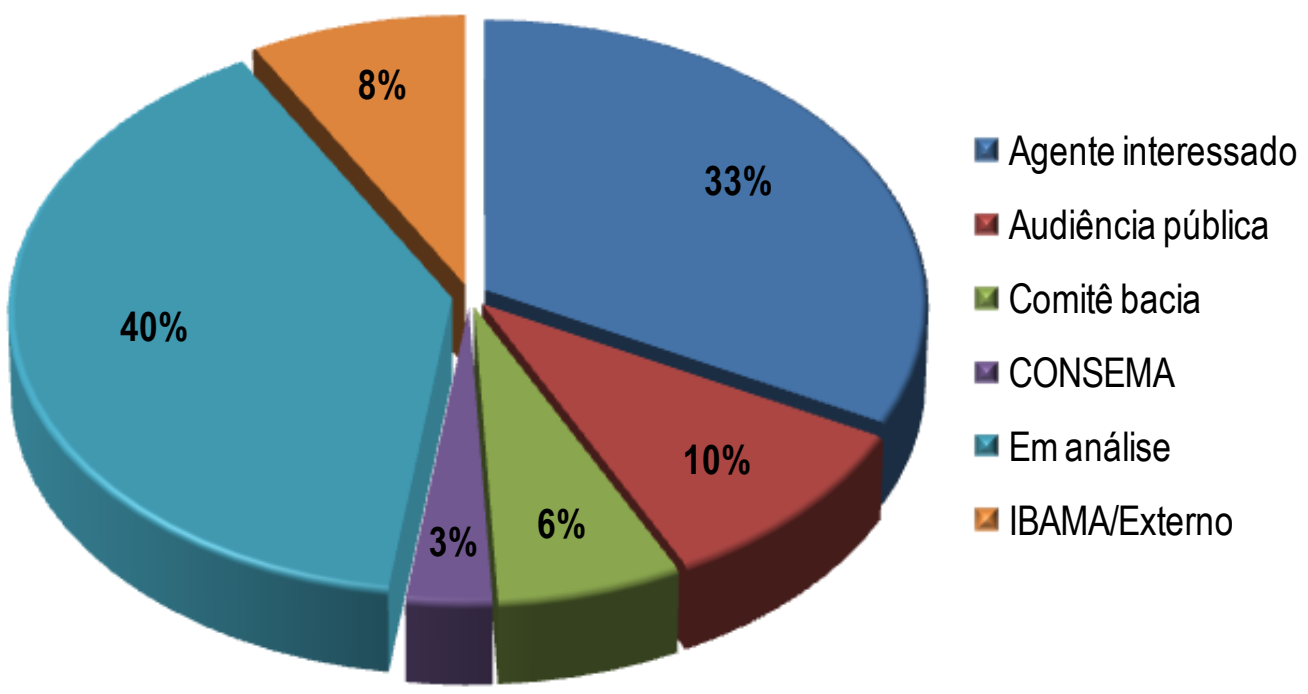

Figura 5.8 - Tramitação de processos de EIA-RIMA na SMA. Maio 2008 a junho 2010 Fonte: Diário Oficial do Estado de São Paulo (2008/2010)

O artifício comumente utilizado é a devolução para os empreendedores dos processos para que complementem as informações e os estudos. Se é razoável complementar os estudos, tal fato não pode ocorrer em $40 \%$ dos processos em tramitação.

A consequência dessa forma excessivamente burocrática de atuação recai nos prazos para o licenciamento de diferentes empreendimentos (Tabela 5.16).

Tabela 5.16 - Tempos despendidos para o Licenciamento Ambiental

\begin{tabular}{l|c}
\hline EMPREENDIMENTO & TEMPO PARA LICENCIAMENTO \\
\hline Trecho Oeste do Rodoanel - SP & 4 anos \\
\hline Trecho Sul do Rodoanel - SP & 5 anos \\
\hline Empreendimento Hidroelétricos & \\
Grande porte & 4,5 anos \\
$\quad$ Médio porte & 3 anos \\
\hline Termelétricos - ESP $^{* *}$ & 3,2 a 3,8 anos \\
\hline
\end{tabular}

Fontes: *Banco Mundial (2008)

${ }^{* *}$ Aguilar (2008) 


\subsubsection{Perspectivas da Reestruturação}

É absolutamente necessária a reformulação do Sistema Ambiental de São Paulo, e há que se louvar as iniciativas recentemente adotadas com as leis de reformulação do CONSEMA e da modificação institucional da CETESB.

Se os objetivos estiverem alinhados com a desburocratização, a descentralização e a transparência das ações, certamente haverá maior sintonia entre os vetores da produção necessários ao desenvolvimento e o do controle ambiental necessário à preservação do ambiente e das aspirações da sociedade.

A racionalização do número de Agências Ambientais, hoje são 39 do DEPRN e 35 da CETESB é um imperativo. Muitas vezes, as duas Agências com funções diferentes coexistem no mesmo espaço físico e concorrem entre si, gerando conflitos de atribuições e retardamento das decisões e prejudicando a tomada de decisão.

Corolário dessas alterações será a adequação do quadro de funcionários, e para tanto é necessário que se faça o redesenho administrativo das agências e de todo o sistema de licenciamento, iniciando-se o trabalho de engenharia dos processos administrativos de concessão das licenças. 


\section{PROPOSTAS PARA O LICENCIAMENTO AMBIENTAL NO ESTADO DE SÃO PAULO}

As seguintes propostas decorrem da análise da experiência internacional e da visão crítica do sistema nacional.

\subsection{Propostas Técnicas}

\subsubsection{Zoneamento Ambiental}

Utilizando as vocações regionais e a avaliação do Estado dos ativos ambientais, será possível estabelecer a capacidade de suporte dos mesmos, de forma a preservá-los e utilizá-los de forma racional, simplificando as tomadas de decisão sobre novos investimentos.

\section{Geotecnologias}

Nos anos 90, com a atenuação e eventual fim da chamada "guerra fria", um conjunto de tecnologias de origem militar se tornou disponível para emprego civil. Como os custos de desenvolvimento estavam praticamente amortizados graças a seu prévio emprego militar, esses novos recursos foram disponibilizados a preços muito competitivos no mercado. São exemplos deste tipo de tecnologia, o GPS (sistema de posicionamento global por satélites), a própria Internet, os serviços de rádiocomunicação global (por satélites de órbita baixa), os processadores de alto desempenho baseados em microcomputadores de baixo custo, os satélites de sensoriamento remoto comerciais com resolução sub-métrica, etc.

Todas essas novas tecnologias podem e devem ser apropriadas pelo Sistema Ambiental, viabilizando novos processos de aquisição de informação para suportar as ações de prevenção, controle dos danos ambientais e agilização dos processos de licenciamento ambiental. 
Assim, propõe-se a criação de um centro de sensoriamento remoto, que visa à obtenção de informação ambiental e à busca do efetivo uso e compartilhamento das informações.

As principais premissas adotadas para o centro devem ser:

- Operação Descentralizada - Respeito às diferentes "missões" dos componentes do Sistema;

- Benefícios de escala e racionalização dos recursos humanos e materiais;

- Definição clara de responsabilidades e obrigações;

- Planejamento e "visão" de longo prazo na concepção do Centro Abrangência Estadual.

A figura 6.1 mostra a operação do centro de sensoriamento remoto.

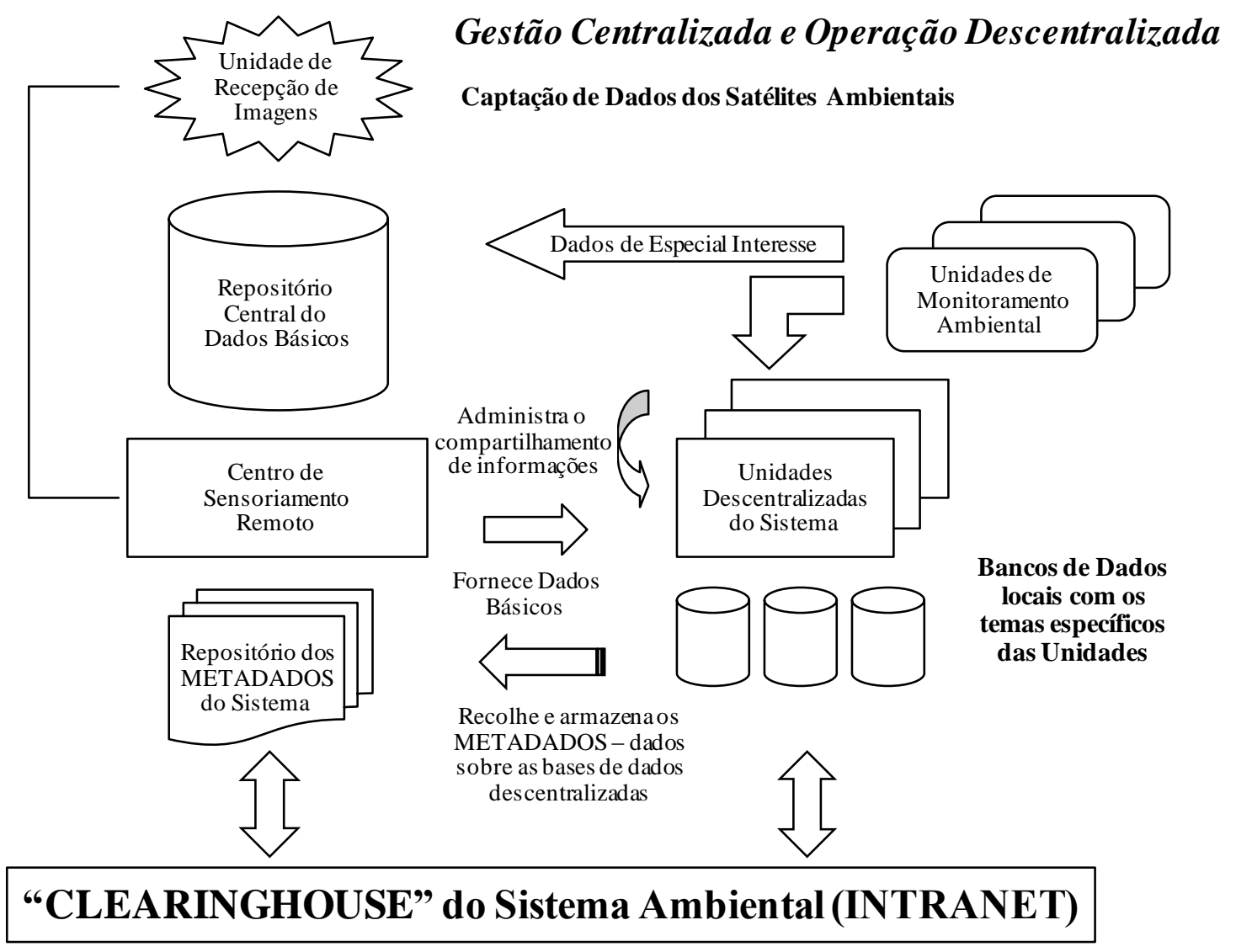

Figura 6.1 - Operação do Centro de Sensoriamento Remoto 
Operação descentralizada - Respeito às diferentes "missões" dos componentes do Sistema

O modelo conceitual proposto contempla as demandas de informação, tanto de projetos específicos como as necessidades associadas às atividades regulares das unidades administrativas da SMA. No modelo proposto, tanto os projetos como as unidades administrativas são classificadas como "unidades descentralizadas", comportando as subdivisões que forem necessárias (hierárquica, funcional e regional); são comsumidores regulares ou eventuais de um conjunto de informações denominadas "Dados Básicos". Exemplos de dados básicos são imagens de satélites, dados de relevo (curvas de nível), divisões político-administrativas, malhas rodoviárias e ferroviárias, rios e represas, etc.

As unidades descentralizadas, além de consumidoras de dados básicos, podem também ser produtoras e "guardiãs" de dados. Obviamente, essas informações devem ter cunho específico e formar "coleções" de dados não-básicos. Sua produção e guarda deve ser inerente à missão institucional da unidade descentralizada. Um exemplo de dado e unidade guardiã descentralizada é o acervo de informação sobre as fontes de poluição administradas pela CETESB. Todas as informações cadastrais relevantes sobre as fontes, exceto as cobertas por sigilo processual, serão parte do repositório central de informações sobre os dados (metadados). O repositório de METADADOS é armazenado e gerenciado pelo Centro, porém os dados, física e logicamente, residem nos bancos de dados da unidade guardiã descentralizada (neste caso, a CETESB) e são por ela mantidos.

Em adição ao conjunto básico de informações do repositório de dados do Centro, cuja tônica é a característica de uso comum às diversas unidades e projetos, este também irá contemplar dados especiais, que são caracterizados pelo interesse geral do Sistema Ambiental. São os dados gerados nas unidades de monitoramento ambiental. Essas unidades são centrais de aquisição de dados telemétricas, mantidas por unidades descentralizadas do Sistema (como a rede de qualidade do ar da CETESB) ou unidades externas (como a central de monitoramento das represas Billings e Guarapiranga, operada pela SABESP). 
Benefícios de Escala e Racionalização dos recursos humanos e materiais

$\mathrm{Na}$ concepção proposta, o Centro deve operar como um "portal" para as necessidades de informações vindas de atores internos e/ou externos ao Sistema Ambiental. Do ponto de vista técnico, trata-se de uma adaptação da tecnologia desenvolvida e utilizada no projeto da NATIONAL GEOSPATIAL DATA CLEARINGHOUSE do governo norte-americano. Esta estrutura prevê usuários e produtores de dados distribuídos. Seus componentes-chave são:

- Documentação dos dados (METADADOS);

- Ligação em REDE (internet) e

- Software para pesquisar, acessar e transportar os dados.

O conceito fundamental para a operação do Centro, segundo o modelo de "Clearinghouse" (Câmara de Compensação), é a adoção de um padrão de documentação sobre os dados (METADADOS). A idéia de documentar precisamente a semântica do dado é explicitar o exato significado daquela informação, sua forma de obtenção, sua validade temporal, eventuais manipulações efetuadas sobre o dado primitivo, etc. Por exemplo, não basta dizer que as coordenadas de uma fonte de poluição são $(x, y)$. Para que se possa interpretar espacialmente esta informação, é necessário acrescentar qual foi o sistema de referência adotado (ou seja, qual a projeção cartográfica e o Datum associados). Seria útil saber também se este ponto $(x, y)$ corresponde ao centróide da área daquela instalação ou se é um ponto sobre a testada principal do lote, ou ainda, como este ponto foi obtido, se foi uma coordenada lida num mapa, uma leitura GPS ou via geocodificação de endereço.

A implantação do conceito de METADADOS é uma mudança tecnológica importante e complexa. Requer treinamento e prática de utilização. Deve ser entendida no contexto exposto inicialmente de informação como bem patrimonial da organização, com custo e valor tangíveis (e muitas vezes elevado). Na realidade, implantar os METADADOS significa realizar um completo inventário de dados no sistema ambiental. 
A proposta para uma implantação rápida da tecnologia de METADADOS é adotar no Centro o padrão do governo norte-americano: Federal Geographic Data Committee's "Content Standard for Digital Geospatial Metadata" Version 2 - 1998 (FGDC-STD001 June 1998). Este padrão é mandatório para as agências federais e seus fornecedores sendo, portanto, o padrão utilizado pela USEPA.

\section{Definição clara de responsabilidades e obrigações}

No modelo proposto, os Banco de Dados ou "Temas de Informação" produzidos da forma regular nas Unidades Descentralizadas (Unidades Administrativas convencionais e os Projetos) passam a ser descritos e acompanhados pelo repositório de metadados. As regras de compartilhamento e disponibilização (e as obrigações decorrentes) são formalizadas de forma muito mais rigorosa e precisa. Cessam as duplicações de esforços e aquisições voltadas para a produção dos temas de interesse comum. As unidades devem produzir apenas as informações pertinentes com sua missão institucional no sistema detendo, contudo, plena autoridade funcional sobre tais informações.

A premissa de compartilhamento e disponibilização não implica em gratuidade dos dados ou disseminação irrestrita; significa apenas que as regras e condições para tanto estão previamente estabelecidas, respeitando o caráter de impessoalidade da administração pública. Uma premissa razoável para operações intra-sistema é a de compartilhamento com recuperação de custos. Com relação às transações extrasistema, é viável uma política de recuperação de investimento mais agressiva, sendo clientes naturais desta categoria os Comitês de Bacia, as Agências Reguladoras e os agentes econômicos privados.

A mudança cultural requerida é profunda, bem como o nível de responsabilidade e efetividade das ações das unidades descentralizadas, que deve aumentar em relação aos padrões atuais.

Desconstruir as ilhas de informação geradas por anos de trabalhos isolados requer firmeza de propósito e um fluxo mínimo e estável de fundos. Todavia, o fator mais 
relevante para o sucesso deste Centro reside na disponibilização e capacitação dos recursos humanos.

Planejamento e "visão" de longo prazo na concepção do Centro - Abrangência Estadual

Os projetos típicos do Sistema Ambiental eram usualmente concebidos com âmbito regional: "Mata Atlântica”, "Serras e Águas", "Projeto Canadá”, Projeto Billings", etc.. Normalmente incluem provisões do tipo “...após sua conclusão, o conhecimento adquirido será estendido/aplicado para outras áreas, regiões, etc”. Em alguns casos, isto até se verifica, mas apenas no aspecto conceitual. As ferramentas geradas são cada vez mais baseadas em informática e, atualmente, num tipo particular de tecnologia - o geoprocessamento (GIS). No contexto necessariamente restrito dos projetos, é muito difícil pensar as questões de perenização e institucionalização em âmbito estadual. O Centro deve cobrir esta lacuna. Operando como unidade permanente do Sistema, ele pode destacar elementos para compor a força tarefa do projeto, que vão zelar pela posterior generalização das ferramentas, metodologias e dados dentro de sua área de competência.

É importante incorporar na missão do Centro e dentro de sua área de competência, a manutenção de canais de cooperação permanentes com as Universidades Paulistas e com os Institutos de Pesquisa, notadamente o IPT e o INPE. No plano internacional, é notável o desenvolvimento das técnicas de sensoriamento remoto baseado nas novas famílias de satélites ambientais e também através dos novos instrumentos aeroportados.

Com a operação do Centro, os técnicos do sistema ambiental poderão rapidamente visualizar a área onde se pretende implantar um determinado empreendimento e as restrições a esta implantação, tais como: áreas contaminadas, áreas de preservação permanente, etc.

Um projeto piloto, denominado SP Janela Eletronica (figura 6.2), com estas características, foi realizado na Secretaria do Meio Ambiente em 2002 a 2003, mas não teve continuidade. 


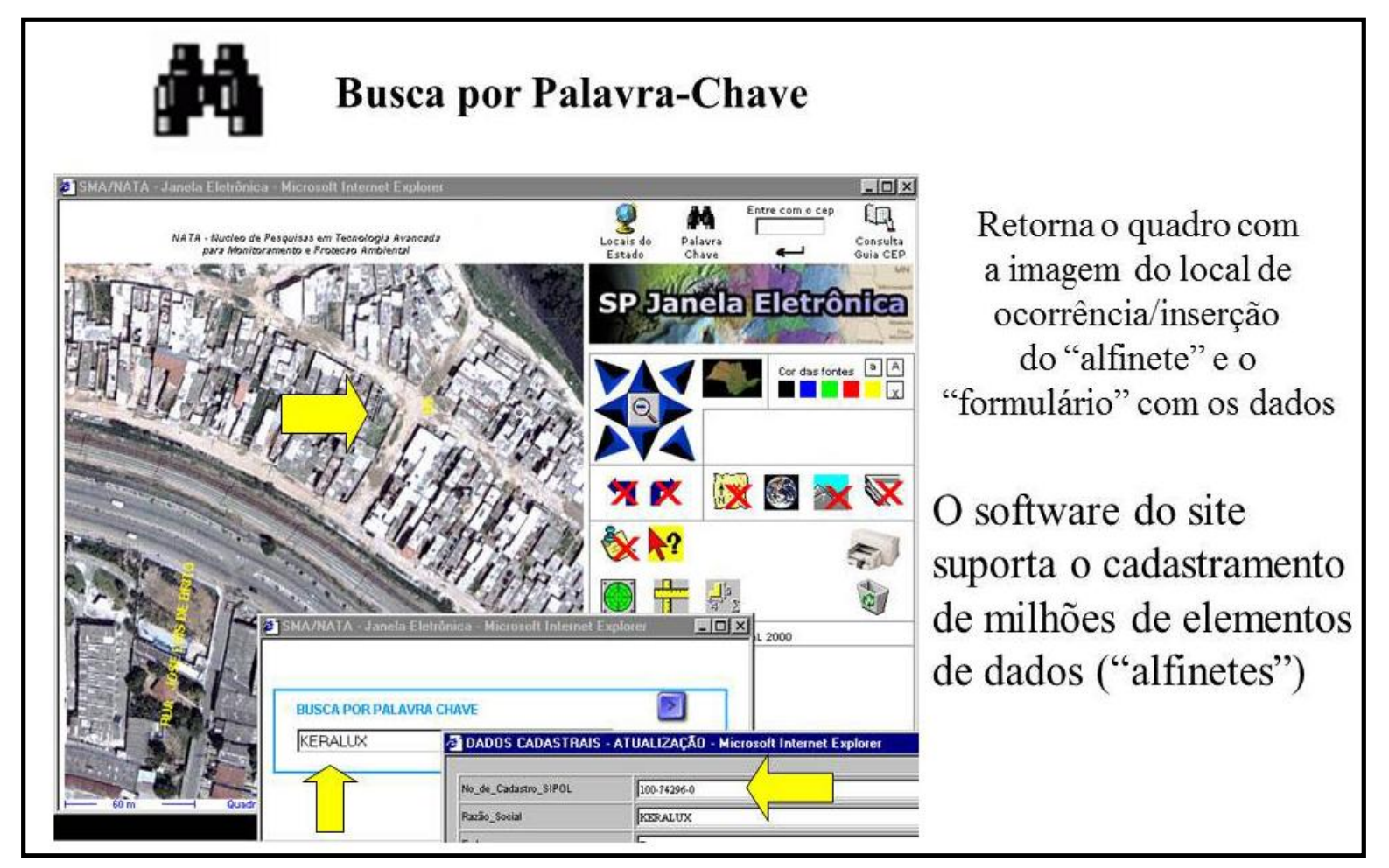

Figura 6.2 - SP Janela eletrônica, exemplo do uso de tecnologia avançada para apoio ao licenciamento ambiental

\subsubsection{Relatório técnico}

Estabelecer o Relatório Técnico Científico do EIA, que seria elaborado por grupo de consultores credenciados e de absoluta confiança e apenso à análise do EIA.

Dessa forma, o EIA poderia ser um documento sintético, permitindo uma análise mais profunda e menos exaustiva.

Esse grupo de Consultores teria a responsabilidade científica pelos trabalhos e serviria de embasamento às decisões administrativas.

A experiência norte-americana nesse procedimento tem obtido sucesso, e os ritos administrativos são simplificados, mais céleres e menos discricionários.

\subsubsection{Padrões de emissão e qualidade}

Os padrões elaborados pelo CONAMA e com abrangência nacional tem se mostrado ineficazes e inaplicáveis nas diferentes regiões de um país continental. 
Eles deveriam ser flexibilizados e cada bacia hidrográfica estabeleceria os padrões aplicáveis, levando em conta suas especificidades.

Os empreendedores deveriam ser estimulados a utilizar no licenciamento e na renovação da licença, a melhor tecnologia disponível e economicamente suportável.

\subsubsection{Acompanhamento das licenças}

Uma grande fragilidade dos sistemas de licenças ambientais tem sido a fase de póslicença. Não há acompanhamento eficiente das medidas mitigadoras dos impactos ambientais.

A introdução de geotecnologias no processo oferece condições de acompanhamento e mais ainda a elaboração de um grande banco de dados que subsidiaria as condições atuais e forneceria parâmetros para decisões futuras.

\subsection{Administrativas}

\subsubsection{Padronização}

Os procedimentos para os licenciamentos devem ser tanto quanto possível padronizados.

Não tem sentido para cada empreendimento fazer-se um termo de referência, cujos prazos excedem aos seis meses.

Empreendimentos semelhantes devem ter seus termos de referência padronizados em sua grande parte, e ser detalhados somente nas suas especificidades.

Esse procedimento pode agilizar os licenciamentos de estações de tratamento de água e de esgoto; de estradas; de centros comerciais; arenas de esportes, etc. 


\subsubsection{Potencial poluidor}

Discretização entre pequeno, médio e grande empreendimento, adequando os procedimentos conforme o grau de comprometimento ambiental em função do porte do empreendimento.

O Sistema de Licenciamento Simplificado - SILIS - é uma iniciativa promissora e lá se encontram duas mil categorias de empresas passíves de serem licenciadas pelo município. Sugere-se que o SEBRAE viabilize linhas de financiamento, a fim de incentivar as micro e pequenas empresas a implantarem tecnologias mais limpas, uma vez que as instalações de controle de poluição isoladas não são suportáveis economicamente. Ao mesmo tempo, deve-se incentivar consórcios destas empresas para o tratamento conjunto quando viável.

Deveriam ser estabelecidos pelo CONAMA padrões mais gerais e eficazes em função do potencial poluidor das empresas, ficando os organismos estaduais responsáveis por parâmetros mais específicos conforme a realidade local.

\subsubsection{Pessoal técnico}

O aprimoramento do quadro técnico operacional do Sistema é ponto crucial.

De um lado, há um grande número de doutores e mestres que estão fora da linha operacional, especialmente nos Institutos de Pesquisa interligados ao Sistema, mas que não prestam serviços operacionais.

Por outro lado, as pesquisas de excelente padrão deveriam ser orientadas para as necessidades fundamentais de uma Agência Ambiental. Não há uma sequer na área de licenciamento. Quando os pesquisadores são chamados, não estão preparados para atender as reais necessidades do Sistema.

Os técnicos ligados às atividades de controle e de licenciamento ambiental devem ser incentivados para atualizar os conhecimentos nas áreas fins da Agência. Esse fato representa uma distorção, pois a Agência de São Paulo sempre foi considerada 
um centro irradiador de tecnologia, e para isso é absolutamente necessária a constante capacitação técnica e gerencial.

\subsubsection{Descentralização}

Descentralização e simplificação dos licenciamentos para os entes municipais.

Os gráficos apresentados sobre o número de licenças em suas diversas formas, que são expedidas pela CETESB, indicam cerca de 31.000 por ano (CETESB 2008). Esse número está indicando que há enorme espaço para simplificação do processo e para a descentralização para os municípios.

O Artigo 6ำ da resolução CONAMA 237/97 estabelece que o licenciamento de atividades de impacto local e daquelas atividades que the forem delegadas pelo Estado, mediante convênio, é de competência municipal.

O município está mais próximo da atividade e tem maiores e melhores condições para exercer tais funções.

Mais significativo ainda se torna a necessidade de um núcleo de geotecnologia ambiental, que poderia subsidiar o município no controle ambiental dessas atividades.

\subsection{Institucional}

\subsubsection{Bacia hidrográfica}

A política pública ambiental deve ser estabelecida por bacia hidrográfica. Tal decisão criaria condições sinérgicas com outras políticas, principalmente com a de recursos hídricos e a de disposição de resíduos.

Facilitaria a definição de padrões ambientais e o controle da sua implementação, possibilitaria melhores condições para a emissão de outorga e cobrança pelo uso da água, e evitaria conflitos de atribuição com o DAEE. 


\subsubsection{Tripla licença}

O Brasil é o único país no mundo que adota três licenças.

Qualquer que seja a função dessas licenças, elas poderiam ser feitas com uma só, como ocorre em todos os outros lugares do mundo.

\subsubsection{Diálogo institucional}

Transparência e diálogo constante com o Ministério Público e com o Poder Judiciário. As formas de operacionalização e dos procedimentos de licenciamento poderiam ser amplamente debatidos através das Escolas de Magistratura e do Ministério Público, que aprofundariam os conhecimentos e os problemas das diversas instituições públicas, criariam um canal de confiança recíproca e aliviariam as tensões para os Agentes Públicos encarregados das atividades de licenciamento.

\subsubsection{Revisão da legislação}

É necessária a revisão e a consolidação da legislação ambiental em todos os níveis. O Tribunal de Contas da União - TCU listou 104 Leis, Decretos e Resoluções relativos ao Licenciamento Ambiental em nível Federal (TCU, 2004); as legislações específicas dos Estados e Municípios levam esse número para cerca de 4.000 dispositivos legais.

O detalhamento da legislação brasileira tem se mostrado absolutamente ineficaz e prejudicial ao desenvolvimento e especialmente ao meio ambiente.

\subsubsection{Compensação ambiental}

A compensação ambiental tem sido utilizada de maneira pouco transparente, com valores exagerados e não correlacionados com os estudos dos impactos a que se refere o empreendimento. 
Esse fato tem conduzido à elevação de custos que se refletirá na tarifa dos serviços públicos, e por conseqüência, irá onerar os valores dos serviços prestados aos consumidores finais.

É absolutamente necessário o estabelecimento de normas e critérios transparentes para a compensação ambiental e a rigorosa fiscalização da aplicação de tais recursos que devem estar estreitamente relacionados com as questões ambientais do empreendimento. 


\section{CONCLUSÕES}

$\mathrm{Na}$ revisão bibliográfica deste trabalho, foram analisados os procedimentos de licenciamento de diversos países, dos quatro continentes, com diferentes graus de desenvolvimento, níveis de renda e de população. Também foram estudadas as formas de abordagem ambiental para diferentes tipos de empreendimentos, tais como construção de barragens, assentamento de grandes extensões de tubulações e estradas. Empreendimentos implantados em áreas de florestas, regiões de mangues e atravessando sítios com alto valor arqueológico foram avaliados. Países com fortes instrumentos legais; outros com fragilidades; alguns com participação popular atuante; outros com comunidades que não conseguiam entender 0 alcance dos projetos; com populações com baixo e com alto nível de renda foram investigados. Concluiu-se desta análise:

- O estudo de impacto ambiental continua a ser o principal instrumento para a avaliação de impacto ambiental (AIA);

- A Avaliação Ambiental Estratégica (AAE) deve ser introduzida desde a formulação das políticas, planos e programas;

- Incorporada a AAE nas políticas e nos planos, a avaliação dos impactos ambientais nos programas específicos, torna-se mais consistente e oferece mais segurança ambiental, especialmente se forem acrescidas as análises de riscos e a avaliação dos impactos sociais;

- É necessário ambientalmente e conveniente economicamente desenvolver um amplo programa de incentivo à prevenção da poluição;

- A participação popular tem importância primordial na tomada de decisão;

- A transparência é fator-chave para o sucesso do processo de licenciamento;

- Os técnicos que analisam o EIA devem ser capacitados e ter oportunidades permanentes de aprimoramentos técnicos; 
- O Brasil é o único país que concede três licenças ambientais;

- Deve ser dada ênfase ao emprego das melhores tecnologias economicamente disponíveis.

$\mathrm{Na}$ análise crítica do sistema de licenciamento ambiental do Estado de São Paulo, chegou-se às seguintes conclusões:

- O processo de licenciamento é ineficiente e tem se tornado ineficaz;

- Os prazos para a concessão dos licenciamentos são excessivamente longos onerando muitas vezes os investimentos, especialmente os de infra-estrutura.

- Não existem programas regulares de acompanhamento e monitoramento das exigências formuladas nas licenças;

- A participação pública ainda é incipiente e pouco incentivada;

- A legislação ambiental federal é muito específica e não leva em consideração as peculiaridades regionais;

- Os preços para concessão de licenças de obras de infra-estrutura urbana, principalmente no que diz respeito ao saneamento e saúde pública, são excessivamente elevados

- Não há discricionariedade entre o pequeno e o grande poluidor;

- É necessário aprimorar permanentemente a capacitação do profissional que faz a análise do licenciamento;

- O processo de licenciamento passou a ser pouco técnico, muito burocrático e vulnerável às injunções políticas.

Em função da revisão da bibliografia e da análise crítica sobre o processo de licenciamento, foi elaborada uma proposta para o Estado de São Paulo, que tem como diretrizes principais:

- Incorporação da Avaliação Ambiental Estratégica na formulação das políticas, planos e programas governamentais; 
- Redução do número de licenças concedidas: sugere-se apenas a licença de operação;

- A adoção do relatório técnico de especialistas independentes, à semelhança do que ocorre nos Estados Unidos da América, que possibilita o aprofundamento dos estudos, melhora sua qualidade e abre a perspectiva de intermediação dos conflitos;

- Utilização da tecnologia da informação, que oferece condições de formação de uma base consistente de dados, tornando mais eficiente e impessoal o processo de licenciamento ambiental, bem como o acompanhamento pós-licença;

- Incentivo ao uso das melhores tecnologias disponíveis e economicamente viáveis;

- Adoção de padrões de emissão em função da categoria industrial;

- Discretização entre o pequeno e grande poluidor;

- Abrangência e custos da compensação ambiental compatíveis com o empreendimento e com relação direta com seus impactos;

- Capacitação contínua do quadro técnico responsável pelo licenciamento;

- Maior transparência nos processos de licenciamentos através da ampla publicidade das diferentes fases; estimular a participação popular responsável através de audiências públicas pela internet;

- As licenças em sua integralidade devem ser disponibilizadas para a sociedade através da mesma rede;

- Descentralização e simplificação do licenciamento para os entes municipais. 


\section{REFERÊNCIAS}

ABAZA, H., BISSET, R., SADLER, B. Enviromental Impact Assessment and Strategic Enviromental Assessment: Towards an Integrated Approach. Hertfordshire, England: Earthprint, United Nations Environment Programme (UNEP), 2004.

ACOSTA, I. Progress of environmental impact assessment and its methods in Colombia. Environmental Impact Assessment Training Resource Manual. Hertfordshire, England: Earthprint, United Nations Environment Programme (UNEP), 2003.

AGUILAR,G.T. Análise do tempo de tramitação de processos de licenciamento ambiental: Estudo de caso de termelétricas no Estado de São Paulo, 2008. Dissertação (Mestrado) Escola de Engenharia de São Carlos - Universidade de São Paulo. São Carlos, 2008. 109 p

AKAOUI, F. R. Compromisso de Ajustamento de Conduta Ambiental. São Paulo: Revista dos Tribunais, 2003.

ALI, O. Environmental Impact Assessment from a Sudanese Perspectrive. Environmental Impact Assessment Training Resource Manual. Hertfordshire, England: Earthprint, United Nations Environment Programme (UNEP), 2003.

ALID, A. Experiences in the first pulp mill project submitted to the environmental impact assessment system in Chile. Environmental Impact Assessment Training Resource Manual. Hertfordshire, England: Earthprint, United Nations Environment Programme (UNEP), 2003.

APPAH-SAMPONG, E. Public Hearing within the environmental impact assessment review process. (2nd ed.). In: UNEP, UNEP EIA Training Resource Manual, Geneva, Switzerland: UNEP, 2003, p. 85-91

ASTORGA, E. Sistema de Evaluación de Impacto Ambiental. Santiago de Chile: Conosur, 2000.

BACOW, L.; WHEELER, M. Environmental Dispute Resolution. New York: Plenum Press, 1984. 
BASAHI, L.A.A. Environmental assessment study of the Safir-Hadramout Road Project. (2nd ed.). In: UNEP, UNEP EIA Training Resource Manual, Geneva, Switzerland: UNEP, 2003, p.7-17

BINGHAM, G. Resolving Environmental Disputes: A Decade of Experience, Washington, DC: The Conservation Foundation, 1986.

BIRD. Banco Internacional de Reconstrução e Desenvolvimento. Licenciamento ambiental de empreendimentos hidrelétricos no Brasil, Brasilia: Banco Mundial, 2008

BISSET, R. Developments in EIA methods. In: WATHERN, P. Environmental Impact Assessment. Theory and Practice. London:Unwin Hyman, 1988.

. Methods of Consultation and Public Participation. In: Lee, N.; George, C. Environmental Assessment in Developing and Transitional Countries: Principles, Methods and Practice. Hoboken, NJ: John Wiley and Sons Ltd, 2000.

BLERUBLE, G. G.; CUSSON, C. The Environmental legal and regulatory frameworks - Assessing Fairness and Efficiency. Energy Policy, v. 30, issue 14, p.1291-1298, 2002.

BOLEA, E. Evaluación de Impacto Ambiental. Madrid: Centro de Estudios Municipales y de Cooperación Internacional (CEMCI),1984.

BOVENBERG, A. L.; MOOIJI, R. H. Environmental levies and distortionary taxation. The American Economic Review, v. 84, n. 4, p. 1085-1089, 1994.

BRAGA FILHO, E. O. O Licenciamento Ambiental - Uma Visão Realista. São Paulo: Editora Fiuza Ltda., 2007.

BRANCO, S. A água e o Homem. In: PORTO, R. (org). Hidrologia Ambiental. São Paulo: Associação Brasileira de Recursos Hídricos (ABRH)/EDUSP, 1991.

BRASIL. Decreto $\mathrm{n}^{\circ}$. 99.274, de 6 de junho de 1990. Regulamenta a Lei $\mathrm{n}^{\circ}$ 6.902, de 27 de abril de 1981, e a Lei no 6.938, de 31 de agosto de 1981, que dispõem, respectivamente sobre a criação de Estações Ecológicas e Áreas de Proteção Ambiental e sobre a Política Nacional do Meio Ambiente, e dá outras providências. Diário Oficial da União, Brasília, 7 de junho de 1990, Seção 1, p. 10887. 
BRASIL. Lei $n^{\circ} .6938$, de 31 de agosto de 1981. Dispõe sobre a Política Nacional do Meio Ambiente, seus fins e mecanismos de formulação e aplicação, e dá outras providências. Diário Oficial da União, Brasília, Seção 1 - 02/09/1981, p. 16509.

BRASIL. Lei no 8429, de 02 de junho de 1992. Dispõe sobre as sanções aplicaveis aos agentes públicos nos casos de enriquecimento ilícito no exercício de mandato, catgo, emprego ou função na Administração Pública Direta, Indireta ou Fundacional e dá outras providências. Diário Oficial da União, Brasília, Seção 1 - 03/06/1992, p. 6993.

BRASIL. Lei no 9605, de 12 de fevereiro de 1998. Dispõe sobre as sanções penais e administrativas derivadas de condutas e atividades lesivas ao meio ambiente, e dá outras providências. Diário Oficial da União, Brasília, Seção Divisão de Orçamento, Finanças e Contabilidade - DOFC - 13/02/1998, p.1.

BRASIL. Resolução CONAMA nํ237, de 19 de dezembro de 1997. Dispõe sobre os procedimentos e critérios utilizados no licenciamento ambiental e no exercício da competência, bem como as atividades e empreendimentos sujeitos ao licenciamento ambiental. Diário Oficial da União, Brasília, 22 de dezembro de 1997, Seção 1, páginas 30841-30843.

BRASIL. Resolução CONAMA n. 1., de 23 de janeiro de 1986. Dispõe sobre procedimentos relativos a Estudo de Impacto Ambiental. Diário Oficial da União, Brasília, 17 de fevereiro de 1986, p. 2548 e 2549.

BROCK, W. A Polluted Golden Age. In: SMITH, V. L. Economics of Natural and Environmental Resources. New York: Gordon and Breach, 1973.

BROWN, A. Beyond EIA - Incorporating environment into the engineering design process. In: National Conference on Environmental Engineering, Gold Coast, Queensland, Australia. (1992). Environmental Engineering 1992: The Global Environment - Australian Implications; Preprints of Papers. Barton, ACT: Institution of Engineers, Austrália, 1992, p. 229-233.

BURKE, G. Handbook of Environmental Management and Technology. New York: Wiley Interscience, 2000.

CAIRNS JR., J.; CRAWFORD, T. Integrated Environmental Management. Chelsea, Michigan: Lewis Publisers, 1991. 
CARSON, J. E. On the preparation of environmental impact statements in the United States of America. Atmospheric Environment, v. 26A, p. 2759 -2768, 1992.

CASCIO, J.; WOODSIDE, G.; MITCHELL, P. ISO 14000 Guide: The New International Environmental Management Standards. New York: McGraw-Hill, 1996.

CAVALCANTI, R.N., A efetividade dos instrumentos jurídicos para a proteção ambiental, 2010. Tese (doutorado) - Faculdade de Direito - Centro de Ciencias Sociais, Universidade do Estado do Rio de Janeiro, Rio de Janeiro, 2010.

COHEN, S.; KAMIENIECKI, S.; CAHN, M. C. Strategic Planning in Environmental Regulation - A Policy Approach that Works. Cumberland, RI: The MIT Press, 2005.

CONFERÊNCIA DAS NAÇÕES UNIDAS SOBRE MEIO AMBIENTE E DESENVOLVIMENTO, 1992, RIO DE JANEIRO. Conferência das Nações Unidas Sobre Meio Ambiente e Desenvolvimento: A Agenda 21. Brasília: Senado Federal, 1995. 471598p. (Série Ação Parlamentar, n. 56).

CORMICK, G. The "theory" and practice of environmental mediation. Environmental Professional, v. 2., p. 24-33, 1980.

CORRÊA, A. Certificação Segundo a ISO 14001: Metodologia para a Revisão Ambiental Inicial, 2000. Tese (Doutorado) - Escola Politécnica, Universidade de São Paulo, São Paulo, 2000.

DALAL-CLAYTON, B.; SADLER, B. Strategic Environmental Assessment -. A sourcebook and reference guide to international experience. London: International Institute for Environment and Development, 2005.

DAMS, W. C. Dams and Development: A New Framework for Decision-Making. Cape Town: World Commission on Dams, 2002.

ESTADO DE SÃO PAULO. Decreto № 24.806 de 25 de julho 1955, Regulamenta as Leis nos. 2182, de 23 de julho de 1953, e 3068 de 14 de julho de 1955, que dispõem, respectivamente sobre a criação de Estações Ecológicas e Áreas de Proteção Ambiental e sobre a Política Nacional do Meio Ambiente, e dá outras providências. Diário Oficial do Estado de São Paulo, São Paulo, 07/06/1955, Seção 1, p. 1. 
ESTADO DE SÃO PAULO. Decreto-Lei no 195-A de 19 de fevereiro de 1970, que dispõe sobre a Proteção dos Recursos Hídricos contra agentes poluidores, e dá providências. Diário Oficial do Estado de São Paulo, São Paulo, 20/02/1970, Seção 1, p 3, retificada no Diário Oficial do Estado de São Paulo, São Paulo, 24/02/1970, Seção $1, \mathrm{p} 3$.

ESTADO DE SÃO PAULO. Decreto № 8468 de 08 de setembro de 1976, Aprova Regulamento que disciplina a execução da Lei 997, de 31/05/1976, que dispõe sobre controle da poluição do meio ambiente. Diário Oficial do Estado de São Paulo, São Paulo 09/09/1976, Seção 1, p 4.

ESTADO DE SÃO PAULO. Decreto ㄲo 30.555 de 03/10/1989, que reestrutura, reorganiza e regulamenta a Secretaria do Meio Ambiente. Diário Oficial do Estado de São Paulo, São Paulo, 04/10/1989, Seção I, p. 12. Retificação no Diário Oficial do Estado de São Paulo, São Paulo, 14/10/1989.

ESTADO DE SÃO PAULO. Decreto no 47.397 de 04 de dezembro de 2002, que dá nova redação ao Título $V$ e ao Anexo 5 e acrescenta os Anexos 9 e 10, ao Regulamento da Lei $n^{\circ} 997$, de 31 de maio de 1976, aprovado pelo Decreto $n^{\circ}$ 8.468, de 8 de setembro de 1976, que dispõe sobre a prevenção e o controle da poluição do meio ambiente. Diário Oficial do Estado de São Paulo, São Paulo 05/12/2002, Seção I, p. 3, retificado no Diário Oficial do Estado de São Paulo, São Paulo, 07/12/2002.

ESTADO DE SÃO PAULO. Decreto № 47.400 de 04 de dezembro de 2002, Regulamenta dispositivos da Lei Estadual n 9.509, de 20 de março de 1997, referentes ao licenciamento ambiental, estabelece prazos de validade para cada modalidade de licenciamento ambiental e condições para sua renovação, estabelece prazo de análise dos requerimentos e licenciamento ambiental, institui procedimento obrigatório de notificação de suspensão ou encerramento de atividade, e o recolhimento de valor referente ao preço de análise. Diário Oficial do Estado de São Paulo, São Paulo 05/12/2002, Seção I, p. 10, retificação no Diário Oficial do Estado de São Paulo, São Paulo, 06/12/2002, Seção I, p. 4.

ESTADO DE SÃO PAULO. Decreto no 53.205 de 03 de julho de 2008, que dá nova redação e acrescenta dispositivos ao Regulamento da Lei oㅜ 997, de 31 de maio de 1976, aprovado pelo Decreto № 8468 , de 8 de setembro de 1976, alterado pelo Decreto oㅜ 47397, de 4 de dezembro de 2002. Diàrio Oficial do Estado de são Paulo, São Paulo, 04/07/2008, Seção I, p. 1, retificação no Diário Oficial do Estado de São Paulo, São Paulo, 09/07/2008, Seção I, p. 18. 
ESTADO DE SÃO PAULO. Decreto $n^{\circ} 55.149$, de 10 de dezembro de 2009, que dá nova redação a dispositivos do Decreto no 47.400 , de 2002, que regulamenta disposições da Lei no 9.509, de 1997, referentes ao licenciamento ambiental, à vista das alterações introduzidas na Lei oํ 118, de 1973, pela Lei oㅜ 13.542, de 2009, e dá providências correlatas. Diário Oficial do Estado de São Paulo, São Paulo 11/12/2009, Seção I, p. 6.

ESTADO DE SÃO PAULO. Lei № 2182 de 23 de julho de 1953, que estabelece normas tendentes à evitar a contaminação e poluição das águas litorâneas ou interiores, correntes ou dormentes. Diário Oficial do Estado de São Paulo, São Paulo, 25/07/1953, http//www.al. sp. gov.br. (Acesso em 13/03/2008)

ESTADO DE SÃO PAULO. Lei no 3068 de 14 de julho de 1955, que dá nova redação aos artigos $1^{\circ}$ e $4^{\circ}$ da lei ํㅡ 2182, de 23/07/1953 (dispõe sobre resíduos lançados nas águas). Diário Oficial do Estado de São Paulo, São Paulo 16/07/1955, http//www.al.sp.gov.br. (Acesso em 13/03/2008)

ESTADO DE SÃO PAULO. Lei no 997 de 31 de maio de 1976, dispõe sobre o controle da poluição do meio ambiente. Diário Oficial do Estado de São Paulo, São Paulo 01/06/1976, retificação no Diário Oficial do Estado de são Paulo, São Paulo, 03/06/1976. http//www.al.sp.gov.br (Acesso em 13/03/2008)

ESTADO DE SÃO PAULO. Lei oo 9509 de 20 de março de 1997, que dispõe sobre a Política Estadual do Meio Ambiente. Diário Oficial do Estado de São Paulo, São Paulo 21/03/1997, Seção I, p. 1 - retificação no Diário Oficial do Estado de São Paulo, 09/04/1997, Seção I, p. 1.

ESTADO DE SÃO PAULO. Lei ㄲo 13.507 de 23/04/2009, que dispõe sobre o Conselho Estadual da Meio Ambiente - CONSEMA. Diário Oficial do Estado de São Paulo, São Paulo 24/04/2009, Seção I, p. 1.

ESTADO DE SÃO PAULO. Lei no 13.542 de 08 de maio de 2009, que altera a denominação da CETESB - Companhia de Tecnologia de Saneamento Ambiental e dá nova redação aos artigos $2^{\circ}$ e $10^{\circ}$ da lei 118 de 29 de junho de 1973, Diário Oficial do Estado de São Paulo, São Paulo 09/05/2009, Seção I, p. 1.

DEMBOWSKI, H., An early prophet of sustainability. $\boldsymbol{D}+\boldsymbol{C}$ Development , v. 30 , p. 424-426, (2003) 
DORNEY, R. The Professional Practice of Environmental Management. New York: Springer Verlag, 1989.

EISENBUD, M; PETROW, H.G. Radioactivity in the atmospheric effluents of power plants that use fossil fuels, Science 144 - p. 288-289, 1964.

EMMELIN, L. Evaluating environmental impact assessment systems. Part 1 Theoretical and methodological considerations. Scandinavian housing and planning Research, v. 15., p. 129-148, 1999.

ERICKSON, S. Fundamentals of Environmental Management. New York: Wiley, 1999.

ESPINOZA, G.; RICHARDS, B. Fundamentals of Environmental Impact Assessment. Washington, DC: Inter-American Development Bank (IDB) \& American Association of Sanitary and Environmental Engineering (AIDIS), 2002.

EUROPEAN ENVIRONMENTAL AGENCY (EEA). Europe's Enviroment: The Fourth Assessment. Luxembourg: Office for Official Publications of the European Communities, 2007.

EVERITT, R. Scoping of Environmental Impact Assessment. Paper presented to EIA Process Strengthening Workshop, Canberra, 1995.

FERRAZ, C. Electoral Politics and Bureaucratic Discretion: evidence from environmental licences and local elections in Brasil, 2007. Disponível em $<$ http://www.cid.harvard.edu/neudc07/docs/neudc07_s1_p20_ferraz.pdf $>$. Acesso em 02 de agosto de 2010.

FINK, D.; JUNIOR HAMILTON, A.; DAWALIBI, M. Aspectos Jurídicos do Licenciamento Ambiental. São Paulo, Brasil: Forense Universitária, 2002.

FIORILLO, C. A.; FERREIRA, R. M. Curso de Direito Ambiental Brasileiro. São Paulo, Brasil: Saraiva, 2008.

Curso de Direito da Energia - Tutela Jurídica da Água do Petróleo e do Biocombustível. São Paulo: Saraiva, 2009.

FREITAS, V. P. A Constituição Federal e a Efetividade das Normas Ambientais. São Paulo: Revista dos Tribunais, 2005. 
FREITAS, V. P.; FREITAS, G. P. Crimes Contra a Natureza. São Paulo: Revista dos Tribunais, 2006.

FRIEDMAN, F. Practical Guide to Environmental Management. Washington D.C: Environmental Law Institute, 1995.

FURTADO, R. The Incorporation of Environmental Costs into Power System Planning in Brazil. 1996. Tese (Doutorado) - Imperial College, Universidade de Londres. Londres, 1996.

GALliANO, A.G. O Método Científico - Teoria e Prática, Haper \& Row do Brasil, 1979

GEORGE, C.; LEE, N. Environmental Assessment in Developing and Transitional Countries, University of Manchester, UK: John Wiley and sons Ltd., 2000.

GIDDENS, A. The Politics of Climate Change. London: Polity Press, 2009.

GLASON, J.; THERIVEL, R. Introduction to Environmental Impact Assessment: Principles and procedures, process, practice and prospects. London: University College of London, UK., 1994.

GOODLAND, R.; SADLER, B. The analysis of Enviromental Sustainability: From Concepts to Applications. International Journal fo Sustainable Development, v.3, p. 2-21, 1996.

HOWARTH, R.; NORGAARD, R. Environmental Valuation under Sustainable Development. The American Economic Review, v. 82, n. 2, p. 473-477, 1992.

. Intergenerational Choices under Global Environmental Change, In: BROMLEY, D.W. ed. The Handbook of Environmental Economics, Cambridge, MA: Basil Blackwell, 1995

HULL, A.P. Comparing effluent releases from nuclear and fossil-fueled power plant. Nucl. News 17(5), p. 51-55, 1974.

INTERGOVERNAMENTAL PANEL ON CLIMATE CHANGE. Contribution of Working Group II to the fourth Assessment Report of The Intergovernamental Panel on Climate Change. New York: Cambridge University Press, 2007. 
KAPILA, D. Environmental Impact Assessment of the Camisea Gas Project: The Importance of Consultantion and Local participation (2nd ed.). In: UNEP, UNEP EIA Training Resource Manual, Geneva, Switzerland: UNEP, 2003.

KATIMA, J.H.Y. Environmental Impact Assessment: for whose needs - Tanzania (2nd ed.). In: UNEP, UNEP EIA Training Resource Manual, Geneva, Switzerland: UNEP, 2003.

KEMP, M. C.; LONG, N. V. The Underexploitation of Natural Resources: A Model with Overlapping Generations. In: KEMP, M. C.; LONG, N. V., eds. Exhaustible Resources, Optmality and Trade, Amsterdam: North-Holland Pub. Co, 1980.

KENNEDY, W. V. Environmental Impact Assessment in North America, Western Europe: What Has Worked, Where, How, Why?. International Environment Reporter, v. 11, p. 257-262, 1988.

KESSLER, J. Strategic Integrated Planning (SIP) for Sustainable Development: Principles and Analytic Framework. Draft Concep Paper presented to the UNEP Steering Group on Integrated Assessment, 14-15 February, Geneva, 2003.

LASTRA, M.A.C., Analisis de la estructura del sistema de evaluacion de impacto ambiental chileno, 2003. Tese (mestrado) - Facultad de Ciencias Forestales y de la Conservacion de la Naturaleza, Universidade de Chile. Santiago do Chile, 2003

LEDEC, G.; QUINTERO, J. Good Dams and Bad Dams: Environmental Criteria for Site Selection of Hydoelectric Projects. Latin America and Caribbean Region, Sustainable Development Working Paper 16. Washington, DC:The World Bank, 2003.

LICHFIELD, N. Community Impact Evaluation, London, UK:UCL Press, 1996

LÖFGREN, K. G. Another Reconciliation Between Economists and forestry Experts: OLG-arguments. Environmental \& Resource Economics, v.1, n. 1, p. 83-95, 1991.

MACDONALD, G. Environment: Evolution of the Concept, Interim Report IR-98077, Laxenburg (Austria): International Institute for Applied Systems, 1998, 20 p.

MACHADO, P. Direito Ambiental Brasileiro (10 ed.). São Paulo: Malheiros, 2002. 
MAHAYRI, I. New Concepts for Environmental Impact Assessment in Syria (2nd ed.). In: UNEP, UNEP EIA Training Resource Manual, Geneva, Switzerland: UNEP, 2003.

MARGERUM, R. Integrated Environmental Management: The Foundations for Successful Practice. Environmental Management , v. 24, p. 151-166, 1999.

MAY, P. Environmental Management and Governance: Intergovernmental Approaches to Hazards and Sustainability. London: Routledge, 1996.

McBRIDE, J. P; MOORE, R. E.; WITHERSPOON, J. P.; BLANCO, R. E. Radiological impact of airborne effluents of coal fired and nuclear power plants. Nuclear Safety, v. 19, p.497-501. 1978.

MEADOWS, D. L., MEADOWS, D. H., RANDERS, J. \& BEHRENS, W.W. Limites do Crescimento. São Paulo: Perspectiva, 1972.

MEMON, A. Devolution of Environmental Regulation: EIA in Malasia (2nd ed.). In: UNEP, UNEP EIA Training Resource Manual, Geneva, Switzerland: UNEP, 2003.

MILARÉ, E. Direito do Ambiente. São Paulo: Revista dos Tribunais, 2004. 429 p.

MINELLI , M. - 5o Encontro Técnico Annual da Associação dos Engenheiros da Cetesb - Ago.2004 - www.asec.org.br. (Acesso em 17/04/2008)

MOGHRABY, A. State of the Enviromental in Sudan. In: UNEP, UNEP EIA Training Resource Manual, Geneva, Switzerland: UNEP, 2003.

MONTEZUMA, T.W.R., Revista Projeto Amazonia. Jun.2007 $1^{\text {a }}$ ed. Diedi/Cenag TRF 1. p.177

MOTTA, R. S. Relatório Preliminar: Estimativas dos Custos de Licenciamento Ambiental dos Empreendimentos Hidrelétricos no Brasil. São Paulo.(2006).

NAREDO, J. M. Ciudades para un futuro más sostenible - La construcción de la ciudad sostenible. Sobre el origen, el uso y el contenido del término sostenible, 1996 Disponível em <http://habitat.aq.upm.es/cs/p2/a004.html>. Acesso em 13 de 07 de 2007.

NINIO, A. Licenciamento Ambiental de Empreendimentos Hidrelétricos no Brasil. Brasilia: Banco Mundial, 2008. 
NORDHAUS, W. D. To Slow or Not to Slow: The Economics of the Greenhouse Effect, Economic Journal, v. 110, n. 407, p. 920-937, 1991

O'CALLAGHAN, P. Integrated Environmental Management Handbook. Chichester, UK. New York: John Wiley \& Sons, 1996.

OECD-ORGANIZATION FOR ECONOMIC COOPERATION AND DEVELOPMENT. Applying Strategic Environmental Assessment (SEA):Good Practice Guidance for Development Cooperation. Paris: DAC-Guidelines and Reference SeriesOECD Publishing, 2006.

OLIVEIRA, A. O Licenciamento Ambiental. São Paulo: Iglu, 1999.

ORTOLANO, L.; JENKINS, B.; ABRACOSA, R. Speculations on When and Why EIA is Effective. Environmental Impact Assessment Review, v. 7, n. 4, p. 285-292, 1987.

PAEZ, C. Environmental Auditing: The Case of Ecuadorian Industry. In: UNEP, UNEP EIA Training Resource Manual, Geneva, Switzerland: UNEP, 2003.

PALERMO, M. A. O gerenciamento ambiental integrado aplicado a obras civis de grande porte, 2001. Tese (Doutorado) - Escola Politécnica, Universidade de São Paulo, São Paulo, 2001.

PARTIDARIO, M. R. Guia de Boas Práticas para Avaliação Ambiental Estratégica-orientações metodológicas. Lisboa: Agência Portuguesa do Ambiente, 2007.

. Strategic Environmental Assessment - principles and potential. In: PETTS, J. Handbook on Environmental Impact Assessment: environmental impact assessment in practice: impact and limitations. London (UK): Wiley-Blackwell, 1999.

PASTAKIA, C.; JENSEN, A. The Rapid Impact Assessment Matrix (RIAM) for EIA. Environmental Impact Assessment Review, v. 18, issue 5, p. 461-482, 1998.

PERALTA, E. Monitoring the construction stage of the H.P. toro hydroelectrc project. In: UNEP, UNEP EIA Training Resource Manual, Geneva, Switzerland: UNEP, 2003. 
POLONEN, I. Quality control and the substantive influence of environmental impact assessment in Finland. Environmental Impact Assessment Review, v. 26, issue 5, p. 481-491, 2006.

RAJVANSHI, A. Assessed Impacts of the proposed Badhghat Hidroeletrict project. In: UNEP, UNEP EIA Training Resource Manual, Geneva, Switzerland: UNEP, 2003.

REGO, P. Formas de Compensação e Mitigação no processo de licenciamento ambiental no Direito Brasileiro. Temas atuais de Direito Ambiental. Brasil.

RIBEIRO, H. Novos Instrumentos de Gestão Ambiental Urbana. São Paulo: Edusp, 2001.

ROSS, W. A. Evaluating Environmental Impact Statements. Journal of Environmental Management, v. 25, n. 2, p. 137-147, 1987.

SADLER, B. A Framework Approach to Strategic Environmental Assessment: Aims, Principles and Elements of Good Practice. In: International Worlshop on Public Participation and Health Aspects in Strategic Enviromental Assessment. 2001, Szentendre, Hungary. Proceedings. Szentendre, Hungary: The Regional Environmental Center for Central and Eastern Europe, 2001a.

A Framework for Environmental Sustainability Assessment and Assurance. Handbook of Enviromental Impact Assessment (Vol. 1). Oxford: Blackwell Scientific, 1999.

Environmental Assessment in a Changing World: Evaluating Practice to Improve Performance. . Final Report of the International Study of the Effectiveness of Environmental Assessment. Ottawa: Ministry of Supply and Services. ed., 1996, 248 p.

.From Environmental Assessment to Sustainability Appraisal Environmental Assessment Yearbook 2002. Lincoln (UK): Institute of Environmental Management and Assessment, Lincoln and EIA Centre, University of Manchester, 2002. p. 145-152

Strategic Environmental Assessment: Status, Challenges and Future Directions, Prague, CZECH REPUBLIC: Ministry of the Environment, 1996, 129 p. 
SHOOBRIDGE, D.; KAPILA, S., Environmental impact assessment of the Camisea Gas Project: The importance of consultation and local participation (2nd ed.). In: UNEP, UNEP EIA Training Resource Manual, Geneva, Switzerland: UNEP, 2003. p. 93-110

STECH, P. 5o Encontro Técnico anual da Associação dos Engenheiros da Cetesb,( Ago. 2004) - in www.asec.org.br, (Acesso em 17.04.2008)

SUSSKIND, L., MACMAHON, G.; ROLLEY, S. Mediating Development Disputes: Some Barriers and Bridges to Successful Negotiation. Environmental Impact Assessment Review, v. 7, p. 127-138, 1987.

SUSSKIND, L.; WEINSTEIN, A. Towards a theory of environmental dispute resolution. Boston College Environmental Affairs Law Review, v. 9, n. 1, p. 311358,1980

TAYLOR, G.; HORAN, A. From cats, dogs, parks and playgrounds to IPC: policy and the evolution of environmental policy in Ireland. British Journal of Politics and International Relations, v. 3, n. 3, p. 369-392, 2001

THERIVEL, R. Strategic Environmental Assessment in Action, Eartscan, London: 2005.

TRENNEPOHL, C.; TRENNEPOHL, T. Licenciamento Ambiental, Niteroi: Impetus, 2ed. p.16, 2008.

TRIBUNAL DE CONTAS DA UNIÃO. Cartilha de Licenciamento Ambiental. Brasilia: Ministério do Meio Ambiente, 2007.

UNITED NATIONS DEVELOPMENT PROGRAM (UNDP). Reducing a Disaster Risk: A Chalenge for Development. New York: New York-UNDP, 2004.

UNITED NATIONS ENVIRONMENT PROGRAMME (UNEP). Environmental Impact Assessment: Issues, Trends and Practice, Preliminary Version. Geneva, Switzerland: UNEP, 1996b.

UNITED NATIONS ENVIRONMENT PROGRAMME (UNEP). Environmental and Trade - A Handbook. Canada: International Institute for Sustainable Development, 2000. 
UNITED NATIONS ENVIRONMENT PROGRAMME (UNEP). UNEP EIA Training Resource Manual - Preliminary Version, Geneva, Switzerland: UNEP, 1996a.

UNITED NATIONS ENVIRONMENTAL PROGRAMM (UNEP). Enviromental Impact Assessment Training Resource Manual. Geneva, Switzerland: Earth Print - UNEP, 2003.

UNITED NATIONS ENVIRONMENTAL PROGRAMM (UNEP). Environmental Impact Assessment Issues - Preliminary Version . Geneva, Switzerland: Earth Print - UNEP, 1996. 701p.

UNITED NATIONS ENVIRONMENTAL PROGRAMM (UNEP). Reference Manual for the Integrated Assessment of trade-Related Policies. Geneva, Switzerland: Earth Print - UNEP, 2001.

VITTA, H. Responsabilidade Civil e Administrativa por Dano Ambiental. São Paulo: Malheiros Ltda., 2008.

VLACHOS, E. Integrated Impact Analysis - A Background Reader. Colorado: Colorado State University, 1987.

WAHAAB, R. A. Sustainable Development and Environmental Imapct Assessment in Egypt: Historical Assessment. The Environmentalist, v. 23, p. 49-70, 2003.

WOOD, C. Environmental Assessment in Developing and Transitional Countries - Screening and Scoping. London, U.K: Willey, 2000. 56 p.

- Environmental Impact Assessment, a comparative review. London: Longman Scientific \& Technical, 1995. $337 \mathrm{p}$.

WORLD BANK. Environmental Assessment Sourcebook (Vol. 1). Washington, D.C.: World Bank, 1991.

WORLD BANK. Strategic Environmental Assessment for Policies An instrument for good governance. Washington, D.C.: World Bank, 2008. 219 p.

WORLD COMMISSION ON ENVIRONMENT AND DEVELOPMENT (WCED). Our Common Future. Oxford: Oxford University Press, 1987.

WORLD ECONOMIC FORUM. Annual Meeting - Global Report. Davos, Switzerland. Disponível em <http://www.weforum.org>. Acesso em 16/03/2008. 
YALE. Yale University, Environmental Performance Index 2010. Disponível em <http://epi.yale.edu>. (Acesso em 25/02/2010).

ZUFFO, A. Seleção e aplicação de métodos multicriteriais ao planejamento ambiental de recursos hídricos, 1998. Tese (Doutorado) - Escola de Engenharia de São Carlos - Universidade de São Paulo. São Carlos, 1998. 